\title{
Assessment of Water-Quality Conditions in the J.B. Converse Lake Watershed, Mobile County, Alabama, 1990-98
}

U.S. Geological Survey

Water-Resources Investigations Report 01-4225

Prepared in cooperation with the

Mobile Area Water and Sewer System 
Cover photographs: Plant nursery, private pond, and cattle grazing in the J.B. Converse Lake watershed (taken by Will S. Mooty, U.S. Geological Survey). 


\section{Assessment of Water-Quality Conditions in the J.B. Converse Lake Watershed, Mobile County, Alabama, 1990-98}

By C.A. Journey and A.C. Gill

U.S. GEOLOGICAL SURVEY

Water-Resources Investigations Report 01-4225

Prepared in cooperation with the

MOBILE AREA WATER AND SEWER SYSTEM

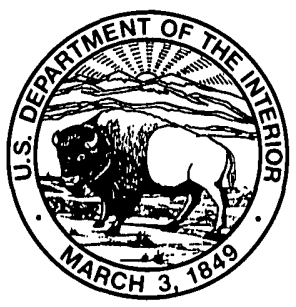




\section{U.S. DEPARTMENT OF THE INTERIOR \\ GALE A. NORTON, Secretary}

U.S. GEOLOGICAL SURVEY

CHARLES G. GROAT, Director

The use of firm, trade, and brand names in this report is for identification purposes only and does not constitute endorsement by the U.S. Geological Survey.

For additional information write to:

Copies of this report can be purchased from:

District Chief

U.S. Geological Survey

2350 Fairlane Drive, Suite 120

Montgomery, AL 36116

U.S. Geological Survey

Branch of Information Services

Box 25286, Federal Center

Email:dc_al@usgs.gov

Denver, CO 80225

1-888-ASK-USGS

Information about U.S. Geological Survey programs in Alabama is available on the Internet at http://al.water.usgs.gov. 


\section{CONTENTS}

Abstract fow

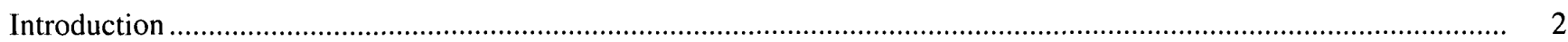

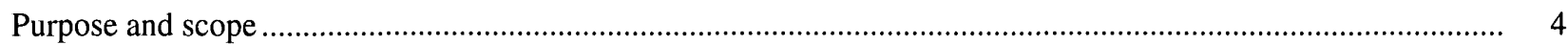

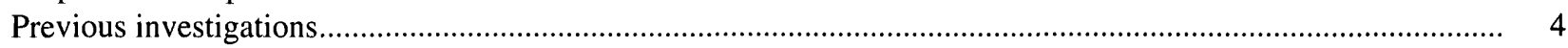

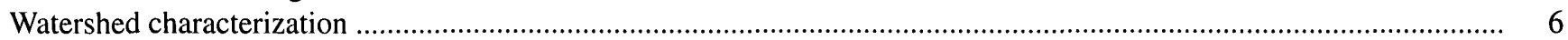

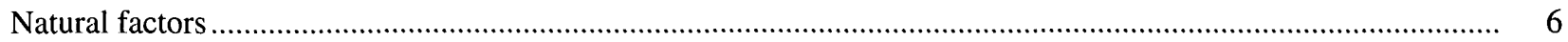

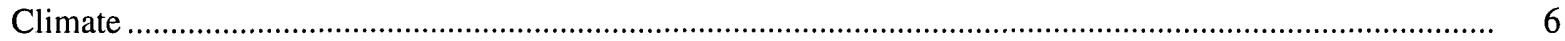

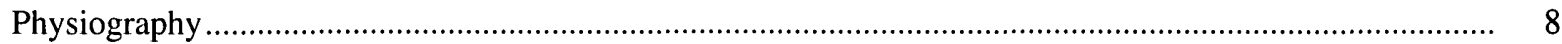

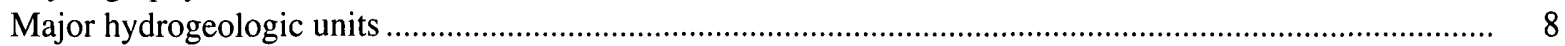

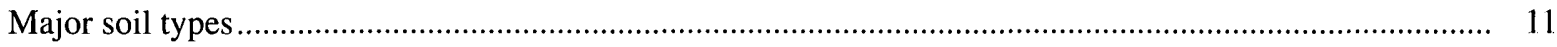

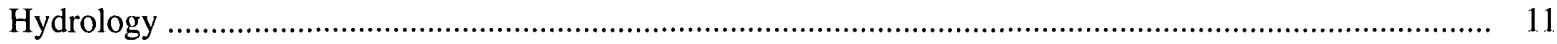

Cultural factors

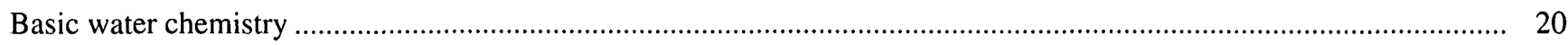

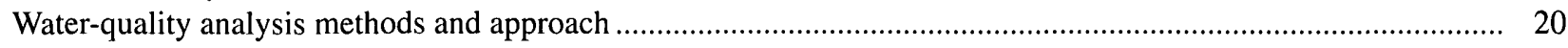

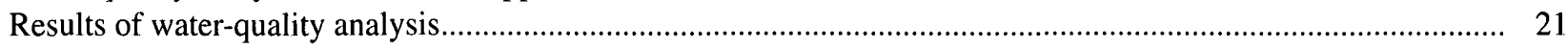

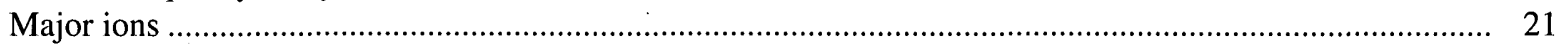

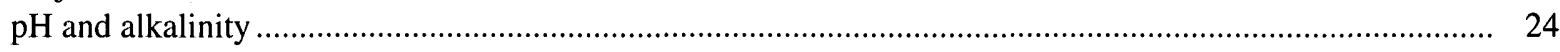

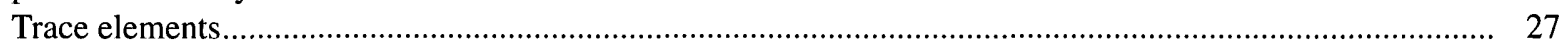

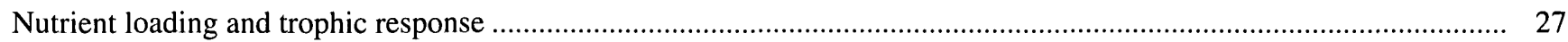

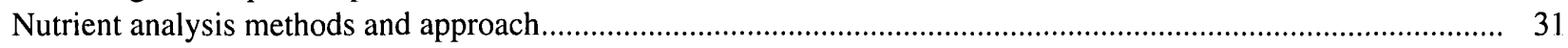

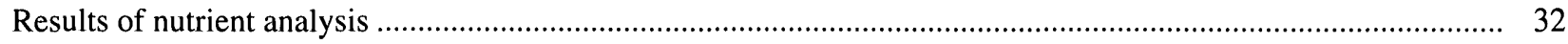

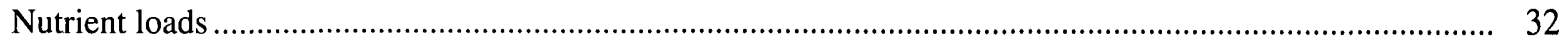

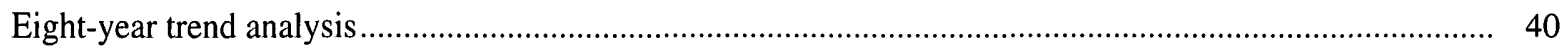

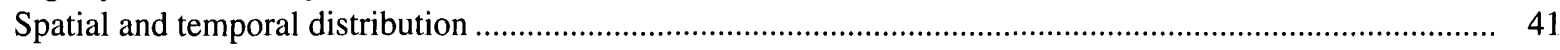

Comparison of nutrient loads with trophic state of lake ........................................................................

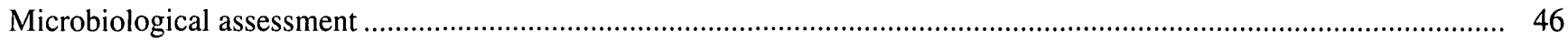

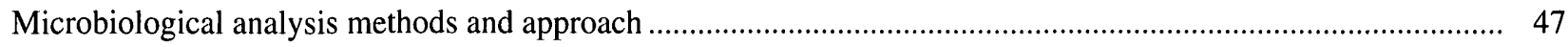

Results of microbiological analysis ........................................................................................................... 47

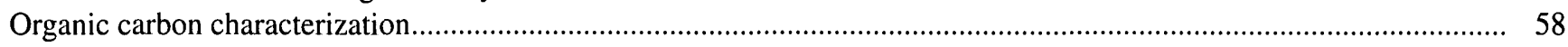

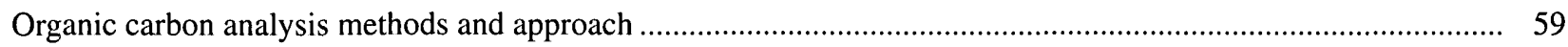

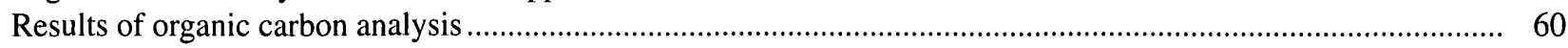

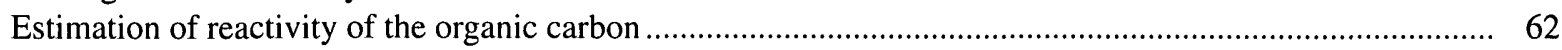

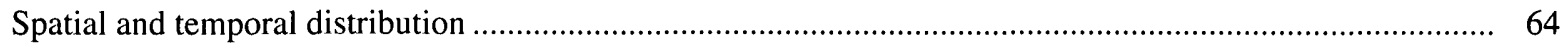

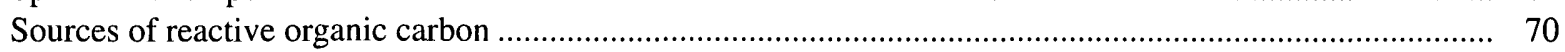

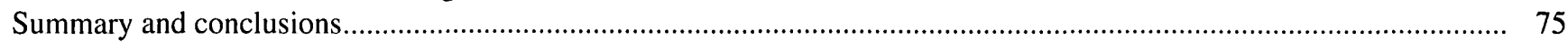

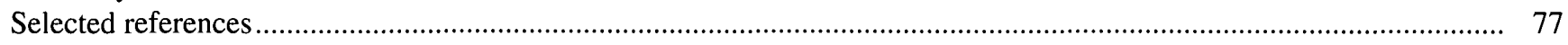

Appendix 1. Summary of descriptive statistics for selected surface-water sites in the J.B. Converse Lake
watershed, Mobile County, Alabama, October 1990-June 1998 ............................................................... 82

Appendix 2. Monthly mean load tables for selected surface-water sites in the J.B. Converse Lake
watershed, Mobile County, Alabama, 1990-98................................................................................. 109

Appendix 3. Methods and results for Giardia and Cryptosporidium analyses for October 1996-May 1998 .................... 129

\section{FIGURES}

1. Map showing locations of data-collection sites in the J.B. Converse Lake watershed in Mobile County, Alabama, 1990-98.

2. Graph showing mean monthly precipitation for $1961-90$ at the Mobile Regional Airport, Alabama.

3. Graph showing total annual precipitation (1990-97) and departure from the mean annual precipitation (1961-90) of 64 inches. 
4. Map showing digital elevation model (DEM) coverage of land-surface slope in subbasins of the Converse Lake watershed, Alabama...

5. Map showing major geologic units in the Converse Lake watershed, Alabama

6. Stratigraphy and lithology of the geologic units and water-bearing properties in the

Converse Lake watershed, Alabama.

7. Map showing major soil associations in the Converse Lake watershed, Alabama.....

8. Graph showing streamflow duration curves for Big Creek, Crooked Creek, and

Hamilton Creek in the Converse Lake watershed, 1990-98

9. Map showing general land uses for the Converse Lake watershed, 1992

10. Pie chart showing land-use percentages in the Converse Lake watershed, 1992.

11. Map showing locations of permitted point sources and plant nurseries in the Converse Lake watershed, 1997

12. Boxplots of $\mathrm{pH}$ and specific conductance values at selected sites in the Converse Lake watershed, 1990-98

13. Radial plots of median ion concentrations, in milliequivalents per liter, at Hamilton Creek, Crooked Creek, Boggy Branch, Converse Lake, Long Branch, Juniper Creek, Collins Creek, and Big Creek in the Converse Lake watershed, 1990-98

14. Radial plots of ionic concentrations, in milliequivalents per liter, at Big Creek, Hamilton Creek, and Crooked Creek during high streamflow conditions and base-flow conditions in the Converse Lake watershed, 1990-98

15. Graph showing correlation between land-use category and median $\mathrm{pH}$ and acid-neutralizing capacity in tributary subbasins in the Converse Lake watershed

16. Boxplots of total and dissolved iron and manganese concentrations at selected sites in the Converse Lake watershed, 1990-98

17. Graphs showing mean annual nutrient yields for three sites in the Converse Lake watershed, 1990-98

18. Boxplots of total Kjeldahl nitrogen, total inorganic nitrogen, total nitrogen, and total phosphorus concentrations at selected sites in the Converse Lake watershed, 1990-98

19. Graphs showing seasonal variations in chlorophyll $a$, and organic and inorganic nitrogen concentrations in the Converse Lake watershed, 1996-98

20. Graph showing temporal variations in nutrient loadings to the lake during the growing season and the lake response to these loadings.

21. Boxplots showing ranges of fecal coliform, fecal streptococcus, and $E$. coli concentrations at selected sites in the Converse Lake watershed, 1990-98

22. Boxplots showing seasonal fecal coliform, fecal streptococcus, and $E$. coli concentrations at selected sites in the Converse Lake watershed, 1990-98

3ap showing ranges in geometric mean concentrations of fecal coliform and fecal streptococcus for 1990-98, and $E$. coli and fecal coliform for 1996-98

24. Scatter plots showing relations between percentages of various land-use types and median fecal coliform concentrations at sites in the Converse Lake watershed

25. Graph showing quarterly and mean results of monitoring for trihalomethane concentrations in treated water at four municipal water supplies in Alabama as part of the Information Collection Rule requirements

26. Graph showing mean trihalomethane concentrations in treated water from selected municipal water supplies in the United States

27. Correlation coefficients and scatter plots of trihalomethane-formation potential and potential surrogate concentrations in the Converse Lake watershed, 1996-98

28. Boxplots of total organic carbon, dissolved organic carbon, and tannin and lignin concentrations at selected sites in the Converse Lake watershed, 1996-98

29. Map showing range in median concentrations of dissolved organic carbon, tannin and lignin, total organic carbon, and ultraviolet absorbance at 254 nanometers in the Converse Lake watershed, 1996-98 
30. Boxplots of ultraviolet absorbance at 254 nanometers for unfiltered (TOC) and filtered (DOC) samples and specific absorbance at selected sites in the Converse Lake watershed, 1996-98

31. Graph showing range in trihalomethane-formation potential for selected tributary and

lake sites in the Converse Lake watershed, 1996-98

32. Graph showing correlation between percent land-use categories and median concentrations of total organic carbon, dissolved organic carbon, tannin and lignin, and ultraviolet absorbance at 254 nanometers in the Converse Lake watershed, 1996-98

TABLES

1. Descriptions of data-collection sites and sampling characteristics in the Converse Lake watershed, Alabama, 1990-98

2. Physical characteristics of Converse Lake.

3. Streamflow conditions in selected tributaries to Converse Lake, October 1990 to September 1998

4. Land use in selected subbasins of the Converse Lake watershed, in acres and percent acreage of subbasin, from 1992 Multi-Resolution Land Characteristics (MRLC) data

5. Spearman rho correlation coefficients for percentage of land use and median levels of $\mathrm{pH}$, acid-neutralizing capacity, and specific conductance in the Converse Lake watershed

6. Potential changes in lake characteristics related to trophic state...

7. National Eutrophication Survey guidelines for trophic state determination.

8. Organization for Economic Cooperation and Development indices for trophic state determination based on scientific opinion

9. Regression summary for the seven-parameter, log-linear model used to estimate nutrient concentrations at selected sites in the Converse Lake watershed

10. Range in nutrient yields from nonpoint sources

11. Annual nutrient loads and yields for selected tributary sites in the Converse Lake watershed for water year 1991

2. Annual and mean annual nutrient loads and yields for Big Creek (site BIG), Converse Lake watershed, water years 1991-98.

3. Annual and mean annual nutrient loads and yields for Crooked Creek (site CRO), Converse Lake watershed, water years 1991-98

14. Annual and mean annual nutrient loads and yields for Hamilton Creek (site HAM), Converse Lake watershed, water years 1991-98

15. Estimated mean annual nutrient contributions to Converse Lake

16. Results of the seasonal Kendall tau test for trends in unadjusted and flow-adjusted nutrient concentrations at selected sites in the Converse Lake watershed, 1990-98.

17. Seasonal and annual change in trophic potential and response variables in Converse Lake, 1992-97

8. Standards and criteria for concentrations of fecal bacteria set by the Alabama Department of Environmental Management and the U.S. Environmental Protection Agency for various water-use classifications.

9. Seasonal median bacterial concentrations for selected sites in the Converse Lake Watershed, 1990-98

20. Geometric means of bacterial concentrations at sites in the Converse Lake watershed

for the period October 1990-June 1998 ......................................................................................

concentrations at selected sites in the Converse Lake watershed, 1990-98............................ General geochemical characteristics of naturally occurring organic carbon compounds in surface water derived from lignin-derived (allochthonous) or microbial/algal-derived (autochthonous) sources

23. Types and potential sources of organic carbon in surface-water samples collected in the Converse Lake watershed. 
24. Spearman rho correlation coefficients for land-use categories and median levels of total organic carbon, dissolved organic carbon, tannin and lignin, and ultraviolet absorbance at 254 nanometers in the Converse Lake watershed.

25. Spearman rho correlation matrix for selected constituents in seven tributary sites and one lake site in the Converse Lake watershed

CONVERSION FACTORS, VERTICAL DATUM, TEMPERATURE, AND ACRONYMS AND ABBREVIATIONS

\begin{tabular}{|c|c|c|}
\hline Multiply & by & To obtain \\
\hline \multicolumn{3}{|c|}{ Length } \\
\hline inch (in.) & 2.54 & centimeter \\
\hline foot $(\mathrm{ft})$ & 0.3048 & meter \\
\hline \multicolumn{3}{|c|}{ Area } \\
\hline square mile $\left(\mathrm{mi}^{2}\right)$ & 259 & hectare \\
\hline square mile $\left(\mathrm{mi}^{2}\right)$ & 2.590 & square kilometer \\
\hline \multicolumn{3}{|c|}{ Flow } \\
\hline cubic foot per second $\left(\mathrm{ft}^{3} / \mathrm{s}\right)$ & 0.02832 & cubic meter per second \\
\hline cubic foot per second per square mile $\left(\left[\mathrm{ft}^{3} / \mathrm{s}\right] / \mathrm{mi}^{2}\right)$ & 0.01093 & cubic meter per second per square kilometer \\
\hline foot per mile $(\mathrm{ft} / \mathrm{mi})$ & 0.1894 & meter per kilometer \\
\hline
\end{tabular}

Sea level: In this report, "sea level" refers to the National Geodetic Vertical Datum of 1929 (NGVD of 1929) - a geodetic datum derived from a general adjustment of the first-order level nets of the United States and Canada, formerly called Sea Level Datum of 1929.

Temperature: Temperature is given in degrees Fahrenheit $\left({ }^{\circ} \mathrm{F}\right)$, which can be converted to degrees Celsius $\left({ }^{\circ} \mathrm{C}\right)$ as follows:

$$
{ }^{\circ} \mathrm{C}=5 / 9\left({ }^{\circ} \mathrm{F}-32\right) \text {. }
$$

$\begin{array}{ll}\text { Acronyms and abbreviations: } \\ \text { ADEM } & \text { Alabama Department of Environmental Management } \\ \text { ANC } & \text { acid-neutralizing capacity } \\ \text { CERCLA } & \text { Comprehensive Environmental Response, Compensation, and Liability Act } \\ \text { DEM } & \text { digital elevation model } \\ \text { DBP } & \text { disinfection by-product } \\ \text { DOC } & \text { dissolved organic carbon } \\ \text { GIS } & \text { geographic information system } \\ \text { HAA } & \text { haloacetic acid } \\ \text { ICR } & \text { Information Collection Rule } \\ \text { LOWESS } & \text { Locally Weighted Regression and Smoothing of Scatter Plots } \\ \text { MAWSS } & \text { Mobile Area Water and Sewer System } \\ \text { MBAS } & \text { methylene blue activated substances } \\ \text { MCL } & \text { maximum contaminant level } \\ \text { MRLC } & \text { Multi-Resolution Land Characteristic } \\ \text { MVUE } & \text { Minimum Variance Unbiased Estimator } \\ \text { NRCS } & \text { Natural Resource Conservation Service } \\ \text { NWIS } & \text { National Water Information System (U.S. Geological Survey database) } \\ \text { OECD } & \text { Organization for Economic Cooperation and Development } \\ \text { PCS } & \text { permit compliance system } \\ \text { PVC } & \text { polyvinyl chloride } \\ \text { STATSGO } & \text { State Soil Geographic Data Base } \\ \text { STORET } & \text { Storage and Retrieval System (U.S. Environmental Protection Agency database) }\end{array}$




\begin{tabular}{|c|c|}
\hline SUVA & specific ultraviolet absorbance \\
\hline THM & trihalomethane \\
\hline THM-FP & trihalomethane-formation potential \\
\hline TIN & total inorganic nitrogen \\
\hline TKN & total Kjeldahl nitrogen \\
\hline TOC & total organic carbon \\
\hline TRI & Toxic Release Inventory \\
\hline TSI & trophic state index \\
\hline USEPA & U.S. Environmental Protection Agency \\
\hline USGS & U.S. Geological Survey \\
\hline UVA & ultraviolet absorbance \\
\hline UV-Vis & Ultraviolet -Visible Spectrum \\
\hline acre-foot & acre-ft \\
\hline B & boron \\
\hline $\mathrm{Br}$ & bromine \\
\hline $\mathrm{C}$ & carbon \\
\hline $\mathrm{Ca}$ & calcium \\
\hline $\mathrm{CaCO}_{3}$ & calcium carbonate \\
\hline $\mathrm{Cl}$ & chlorine \\
\hline $\mathrm{cm}$ & centimeter \\
\hline $\mathrm{col} / 100 \mathrm{~mL}$ & colonies per 100 milliliters \\
\hline $\mathrm{CO}_{3}$ & carbonate \\
\hline $\mathrm{F}$ & fluorine \\
\hline $\mathrm{Fe}$ & iron \\
\hline $\mathrm{ft}^{3} / \mathrm{s}$ & cubic feet per second \\
\hline $\mathrm{g} / \mathrm{d}$ & gram per day \\
\hline $\mathrm{g} / \mathrm{yr}$ & gram per year \\
\hline $\mathrm{HCO}_{3}$ & bicarbonate \\
\hline $\mathrm{Hg}$ & mercury \\
\hline $\mathrm{K}$ & potassium \\
\hline $\mathrm{kg}$ & kilogram \\
\hline $\mathrm{kg} / \mathrm{d}$ & kilogram per day \\
\hline$(\mathrm{kg} / \mathrm{ha}) / \mathrm{yr}$ & kilogram per hectare per year \\
\hline $\mathrm{kg} / \mathrm{yr}$ & kilogram per year \\
\hline $\mathrm{m}$ & meter \\
\hline $\mathrm{m}^{2}$ & square meter \\
\hline $\mathrm{Mg}$ & magnesium \\
\hline $\mathrm{mg} / \mathrm{L}$ & milligram per liter \\
\hline$(\mathrm{mg} / \mathrm{L}) / \mathrm{yr}$ & milligram per liter per year \\
\hline $\mathrm{mL}$ & milliliter \\
\hline $\mathrm{mm}$ & millimeter. \\
\hline $\mathrm{Mn}$ & manganese \\
\hline $\mathrm{m} / \mathrm{yr}$ & meter per year \\
\hline $\mathrm{N}$ & nitrogen \\
\hline $\mathrm{Na}$ & sodium \\
\hline $\mathrm{nm}$ & nanometer \\
\hline $\mathrm{P}$ & phosphorus \\
\hline ppm & parts per million \\
\hline $\mathrm{SiO}_{2}$ & silica \\
\hline $\mathrm{SO}_{4}$ & sulfate \\
\hline$\mu \mathrm{g} / \mathrm{L}$ & microgram per liter \\
\hline$\mu \mathrm{S} / \mathrm{cm}$ & microsiemens per centimeter \\
\hline UVA-DOC & ultraviolet absorbance of dissolved organic carbon at 254 nanometers \\
\hline UVA-TOC & ultraviolet absorbance of total organic carbon at 254 nanometers \\
\hline
\end{tabular}

Water year is the period October 1 through September 30 and is identified by the year in which it ends. 
. 


\title{
Assessment of Water-Quality Conditions in the J.B. Converse Lake Watershed, Mobile County, Alabama, 1990-98
}

\author{
By C.A. Journey and A.C. Gill
}

\section{ABSTRACT}

J.B. Converse (Converse) Lake is a 3,600acre, tributary-storage reservoir in Mobile County, southwestern Alabama. The lake serves as the primary drinking-water supply for the city of Mobile. The Converse Lake watershed lies within the Coastal Plain Physiographic Province.

Semiconsolidated to unconsolidated sediments of sand, silt, gravel, and clay underlie the watershed, and are covered by acidic soils. Land use in the watershed is mainly forest (64 percent) and agriculture (31 percent). Residential and commercial development account for only 1 percent of the total land use in the watershed.

Converse Lake receives inflow from seven major tributaries. The greatest inflows are from Big Creek, Crooked Creek, and Hamilton Creek that had mean annual streamflows of 72.2, 19.4, and 25.0 cubic feet per second, respectively, for the period 1990 to 1998 , which represents about 72 percent of the total annual streamflow to the lake. The total mean annual inflow to the lake is estimated to be about 163 cubic feet per second.

In general, water quality in Converse Lake and its tributaries meets the criteria established by the Alabama Department of Environmental Management (ADEM) for drinking-water supplies, whole-body contact, and aquatic life. The exceptions include acidic $\mathrm{pH}$ levels, iron and manganese levels above secondary or aesthetic criteria, and fecal bacterial levels in some tributaries above whole-body contact (swimmable) criteria. The $\mathrm{pH}$ levels throughout the watershed were commonly below the criteria level of 6.0, but this appears to have been a naturally occurring phenomenon caused by poorly buffered soil types, resistant sediments, and forested land use. Median iron and manganese levels were above aesthetic criteria levels of 300 and 50 micrograms per liter, respectively, in some tributaries. All tributary sites in the Converse Lake watershed had median and minimum dissolved-oxygen concentrations above the ADEM criteria level of 5 milligrams per liter except for Boggy Branch, which had a minimum dissolved-oxygen concentration of 3.7 milligrams per liter.

The degree to which nutrient contributions from tributaries were causing nutrient enrichment and eutrophication in Converse Lake was assessed. Trend analysis detected little or no change in nutrient concentrations at the tributary and lake sites in the Converse Lake watershed from the 1991 to 1998 water years. Nutrient concentrations at most tributary sites exhibited a significant, positive relation with streamflow that indicated the dominant source of nutrient input to the watershed is from nonpoint contributions. From 1990 to 1998, computed mean annual loads of 75,400 kilograms of total nitrogen, 36,950 kilograms of total Kjeldahl nitrogen, 28,870 kilograms of total inorganic nitrogen, and 3,480 kilograms of total phosphorus were contributed to the lake by Big Creek, Hamilton Creek, and Crooked Creek combined. These mean 
annual loads of nutrients corresponded to borderline eutrophic/mesotrophic conditions in the lake. Of the combined loads, 62 percent of the total nitrogen, 70 percent of the total Kjeldahl nitrogen, 54 percent of the total inorganic nitrogen, and 47 percent of the total phosphorus originated from the forested subbasin of Big Creek. The more residential and agricultural subbasins of Crooked Creek and Hamilton Creek, however, yielded over twice the total phosphorus load per hectare of land use. Crooked and Hamilton Creek subbasins also had higher yields of the more bioavailable total inorganic nitrogen. A simplistic empirical model could not explain the relation between year-to-year nutrient contributions to Converse Lake from the tributaries and the lake's ability to assimilate those contributions.

The potential presence of pathogens in the lake and its tributaries was assessed based on fecal bacterial concentrations. Fecal bacterial concentrations at some tributary sites were above existing criteria for swimmable uses.

Contributions of fecal bacteria from tributaries to the lake, however, did not appear to affect the lake because fecal bacterial concentrations at lake sites were one to two orders of magnitude lower than tributary sites and well below criteria levels. Juniper Creek had the highest fecal bacterial concentrations during the study. Trend analysis showed that flow-adjusted fecal streptococcus concentrations increased at Juniper Creek during the 8 years of data collection. Giardia cysts and Cryptosporidium oocysts were detected infrequently at sites in the lake and the raw-water intake during the monitoring effort. Most of the detections occurred during the summer months, but no clear relation between season and cyst density or cyst concentrations in the water supply can be established because of the infrequent detections.

Naturally occurring organic carbon compounds derived from the decay of plant material on land were the major source of organic carbon in the Converse Lake watershed. Reactive organic carbon had a greater potential to form trihalomethanes as a result of chlorination during water treatment. In the lake, algae was considered an important source of organic carbon as indicated by strong, positive, statistically significant correlations among chlorophyll $a$, total organic carbon, and dissolved organic carbon. The algalderived organic carbon, however, was not considered the major source of the reactive organic carbon as indicated by the absence of significant statistical correlations between chlorophyll $a$, total organic carbon, dissolved organic carbon, ultraviolet absorbance at 254 nanometers, and trihalomethane-formation potential.

\section{INTRODUCTION}

J.B. Converse Lake, formerly known as Big Creek Lake and hereafter referred to as Converse Lake, is a 3,600-acre tributary-storage reservoir in Mobile County in southwestern Alabama (fig. 1). The lake is the primary source of drinking water for the Mobile area and a popular recreational spot for fishing and boating activities, although swimming and water skiing are prohibited. The warm Gulf Coast climate attracts recreational fishermen year round to the lake, and supports a growing plant nursery industry in the watershed. At present (2001), the watershed is mostly forested and rural, although residential development has increased throughout the area during the past 10 years.

Rapid, unmanaged, and(or) pervasive changes in human activities in a watershed can have profound, long-term effects on the water quality of a lake or reservoir. Because Converse Lake serves as a source of drinking water, it is important to understand the effects that land use and future development may have on water quality. To effectively manage and protect the water resources of the lake, the following three questions must be answered.

1. Does the water quality of the lake and its tributaries meet the intended uses of the water?

2 . Is the water quality of the lake and its tributaries changing over time?

3. What real or potential sources of water-quality problems exist in the watershed?

This report addresses these questions and also serves as a source-water assessment, which is a required part of the new protection strategy for public water supplies in Alabama. 


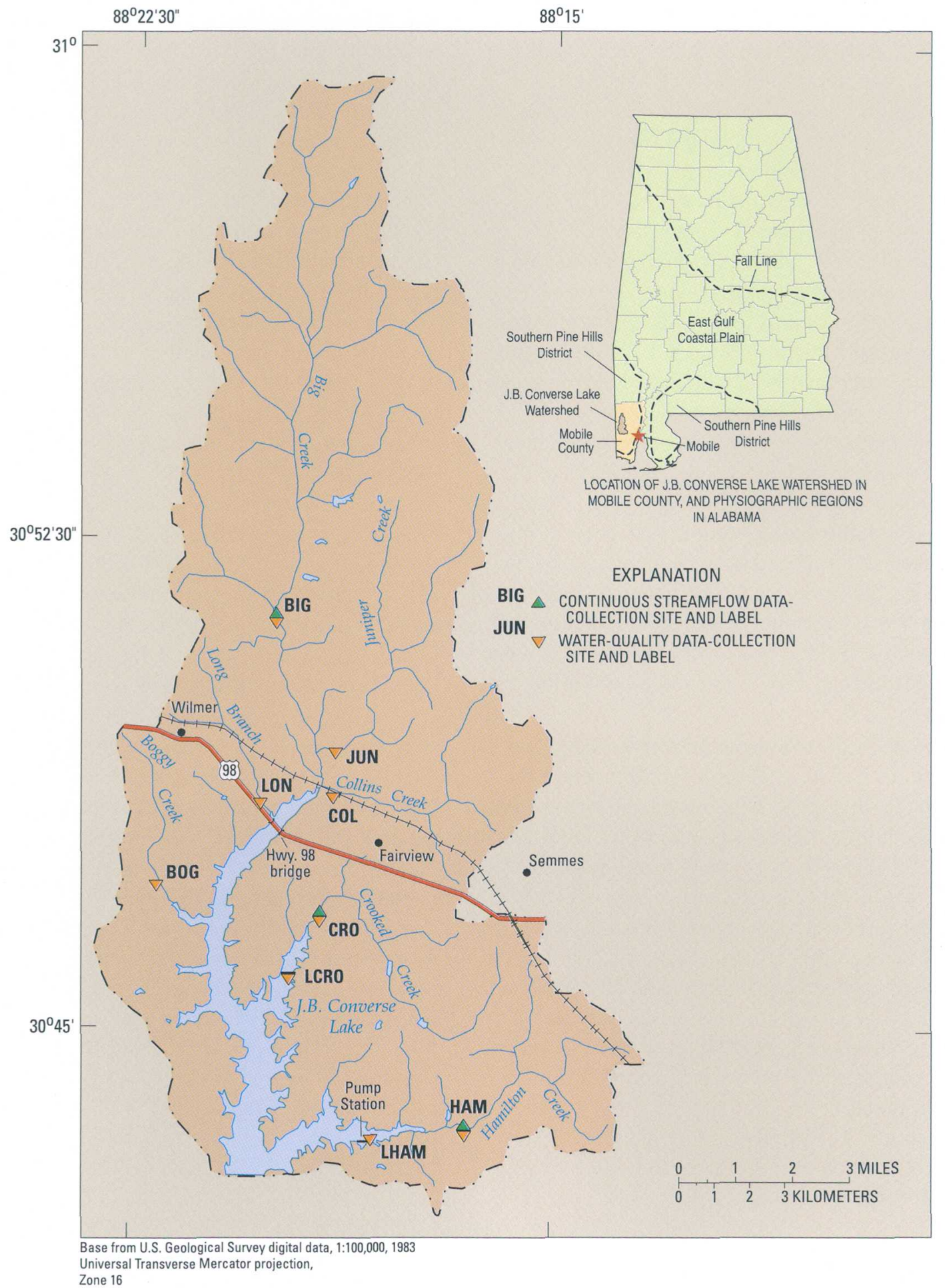

Figure 1. Locations of data-collection sites in the J.B. Converse Lake watershed in Mobile County, Alabama, 1990-98. 
The Mobile Area Water and Sewer System (MAWSS) manages Converse Lake and the E. Morgan Stickney and Harry E. Myers Water Filtration Facilities. These two facilities treat the raw water withdrawn by a pumping station on Converse Lake (site LHAM; fig. 1), and then deliver treated water to the city of Mobile. Much of the land surrounding the lake is covered by a combination of evergreen and deciduous forest and is owned by the MAWSS. The remaining part of the watershed consists of a combination of forest, pastures and dairy farms, plant nurseries, pecan groves, and residential areas that include septic-tank systems for sewage disposal. These land uses contribute nonpoint sources of pollutants that influence the water quality in Converse Lake and its tributaries. Runoff from rainfall in the watershed washes contaminants from the land surface into the tributaries, which in turn deliver contaminants to the lake. Sediment, fecal indicator bacteria, organic carbon compounds, and nutrients commonly are present in runoff from agricultural and rural residential areas, and can impair the quality of water. Effluent from septictank systems also can contribute similar contaminants during periods of little or no runoff if the density of the tanks exceeds the capacity of the soil to assimilate the sewage.

Elevated nutrient concentrations in lake water can produce excessive algal growth and increase the total organic carbon present in the water. The presence of fecal indicator bacteria in the lake water requires treatment of drinking water with chlorine-related disinfectants. During this disinfection process, however, the chlorine can react with naturally occurring or culturally derived organic carbon compounds to produce by-products that are suspected carcinogens. Any process that increases the level of total organic carbon present in the raw water, increases the chances for these by-products to form during the disinfection processes.

\section{Purpose and Scope}

The purpose of this report is to describe the assessment of water quality in the Converse Lake watershed during 1990-98 and the influence of landuse practices on water quality in the watershed. The U.S. Geological Survey (USGS), in cooperation with the MAWSS, began monitoring streamflow and water quality in the Converse Lake watershed in October 1990. The focus of this monitoring program is on the temporal and spatial distribution of concentrations of nutrients, fecal bacteria, and organic carbon in the lake and its tributaries. The water-quality data and analytical results presented in this report will be useful in managing and protecting the drinking-water supply for the city of Mobile. Providing information to better define and manage the quality of water resources is among the highest priority issues of the Cooperative Water Program of the USGS. This investigation also provides information to improve watershed characterization of local sources of water supply, determine the effects of land-use practices on surfacewater quality, and identify waterborne microbiological threats to human health, all of which are priority issues of the Cooperative Water Program.

A data-collection network was established at seven tributary sites and two lake sites in the Converse Lake watershed (fig. 1; table 1). Concentrations of nutrients and fecal bacterial indicator levels have been monitored at these sites at varying frequencies (monthly to quarterly) since October 1990, and concentrations of organic carbon have been monitored monthly since October 1996. Three gaging stations located on major tributaries to Converse Lake (fig. 1) collect continuous streamflow record.

This report consists of four sections that discuss spatial and temporal variations in basic water chemistry, nutrients, fecal indicators, and organic carbon and their relation to land-use practices in the watershed. Additionally, the nutrient section includes the estimated annual nutrient load data from three gaged tributary sites in the watershed, an 8-year trend analysis of the nutrient concentrations in the lake and its tributaries, and a comparison of annual nutrient loads to the trophic state of the lake. The microbiological assessment section describes the 8 -year trend analysis of fecal coliform and fecal streptococcus concentrations in the lake and its tributaries and compares the levels of fecal indicator bacteria to the Alabama Department of Environmental Management (ADEM) water-quality standards and criteria. The organic carbon section characterizes the reactive nature of organic carbon and its probable source (algal, terrestrial).

\section{Previous Investigations}

States are required by section 314(a) of the Clean Water Act to conduct assessments of the water quality of publicly owned lakes (U.S. Environmental 
Table 1. Descriptions of data-collection sites and sampling characteristics in the Converse Lake watershed, Alabama, 1990-98 [USGS, U.S. Geological Survey; $\mathrm{mi}^{2}$, square mile; Q, quarterly; M, monthly; _, not applicable]

\begin{tabular}{|c|c|c|c|c|c|c|c|c|}
\hline \multirow{2}{*}{$\begin{array}{c}\text { Site } \\
\text { label } \\
\text { (fig. 1) }\end{array}$} & \multirow{2}{*}{$\begin{array}{c}\text { USGS } \\
\text { station } \\
\text { number }\end{array}$} & \multirow[b]{2}{*}{ Station name } & \multirow{2}{*}{$\begin{array}{c}\text { Drainage } \\
\text { area } \\
\left(\mathrm{mi}^{2}\right)\end{array}$} & \multicolumn{5}{|c|}{ Sampling frequency } \\
\hline & & & & Streamflow & $\begin{array}{l}\text { Major } \\
\text { ions }\end{array}$ & Nutrients & $\begin{array}{c}\text { Fecal } \\
\text { bacteria }\end{array}$ & $\begin{array}{l}\text { Organic } \\
\text { carbon }\end{array}$ \\
\hline BIG & 02479945 & $\begin{array}{l}\text { Big Creek at County Road } 63 \text { near } \\
\text { Wilmer }\end{array}$ & 31.5 & $\begin{array}{l}\text { Continuous } \\
\text { record }\end{array}$ & $\mathrm{Q}$ & $\begin{array}{l}M^{\mathrm{a}} \\
\mathrm{Q}^{\mathrm{b}}\end{array}$ & $\begin{array}{l}\mathrm{M}^{\mathrm{c}} \\
\mathrm{Q}^{\mathrm{d}}\end{array}$ & $\mathrm{M}^{\mathrm{e}}$ \\
\hline JUN & 02479948 & $\begin{array}{l}\text { Juniper Creek at Glenwood Road } \\
\text { near Fairview }\end{array}$ & 9.22 & Partial record & Q & $\begin{array}{l}M^{a} \\
Q^{b}\end{array}$ & $\begin{array}{l}M^{c} \\
Q^{d}\end{array}$ & $\mathrm{M}^{\mathrm{e}}$ \\
\hline COL & 02479950 & $\begin{array}{l}\text { Collins Creek at Glenwood Road } \\
\text { near Fairview }\end{array}$ & 8.54 & Partial record & $\mathrm{Q}$ & $\begin{array}{l}M^{a} \\
Q^{b}\end{array}$ & $\begin{array}{l}M^{c} \\
Q^{d}\end{array}$ & $\mathrm{M}^{\mathrm{e}}$ \\
\hline $\mathrm{LON}$ & 02479955 & Long Branch near Wilmer & 2.85 & Partial record & Q & $\begin{array}{l}M^{\mathrm{a}} \\
\mathrm{Q}^{\mathrm{b}}\end{array}$ & $\begin{array}{l}M^{c} \\
Q^{d}\end{array}$ & $\mathrm{M}^{\mathrm{e}}$ \\
\hline BOG & 02479960 & Boggy Branch near Wilmer & 3.17 & Partial record & $\mathrm{Q}$ & $\begin{array}{l}M^{\mathrm{a}} \\
Q^{\mathrm{b}}\end{array}$ & $\begin{array}{l}M^{c} \\
Q^{d}\end{array}$ & $\mathrm{M}^{\mathrm{e}}$ \\
\hline $\mathrm{CRO}$ & 02479980 & Crooked Creek near Fairview & 8.08 & $\begin{array}{c}\text { Continuous } \\
\text { record }\end{array}$ & $\mathrm{Q}$ & $\begin{array}{l}M^{\mathrm{a}} \\
\mathrm{Q}^{\mathrm{b}}\end{array}$ & $\begin{array}{l}M^{c} \\
Q^{d}\end{array}$ & $\mathrm{M}^{\mathrm{e}}$ \\
\hline LCRO & 02479985 & $\begin{array}{l}\text { Crooked Creek at mouth (Lake) } \\
\text { near Wilmer }\end{array}$ & - & - & $Q^{f}$ & $Q^{f}$ & $\mathrm{M}^{\mathrm{f}}$ & $\mathrm{M}^{\mathrm{e}}$ \\
\hline HAM & 02480002 & $\begin{array}{l}\text { Hamilton Creek at Snow Road near } \\
\text { Semmes }\end{array}$ & 8.22 & $\begin{array}{l}\text { Continuous } \\
\text { record }\end{array}$ & $\mathrm{Q}$ & $\begin{array}{l}M^{\mathrm{a}} \\
\mathrm{Q}^{\mathrm{b}}\end{array}$ & $\begin{array}{l}M^{c} \\
Q^{d}\end{array}$ & $\mathrm{M}^{\mathrm{e}}$ \\
\hline LHAM & 02480004 & $\begin{array}{l}\text { Hamilton Creek (Lake at the intake) } \\
\text { near Semmes }\end{array}$ & - & - & $\mathrm{Q}$ & $\begin{array}{l}M^{\mathrm{a}} \\
\mathrm{Q}^{\mathrm{b}}\end{array}$ & $\begin{array}{l}M^{c} \\
Q^{d}\end{array}$ & $\mathrm{M}^{\mathrm{e}}$ \\
\hline
\end{tabular}

\footnotetext{
"Monthly samples were collected for the period October 1990 to September 1992.

buarterly samples were collected for the period October 1992 to June 1998.

${ }^{\mathrm{C}}$ Monthly samples were collected for the periods October 1990 to September 1992 and October 1996 to June 1998.

dQuarterly samples were collected for the period October 1992 to September 1996.

${ }^{\mathrm{e}}$ Monthly samples were collected for the period October 1996 to June 1998.

${ }^{f}$ All samples were collected in October 1996.
}

Protection Agency, 1981, 1989). In compliance with the Clean Water Act requirements, the ADEM initiated the Reservoir Water Quality Monitoring Program in 1990 to address trophic-state trends in lakes. The results of ADEM's monitoring program were published for 1985 to 1995 (Alabama Department of Environmental Management, 1996) and for 1997 (Alabama Department of Environmental Management, 1999).

Development of anoxic, or oxygen-depleted, conditions during stratification is a common occurrence in mesotrophic and eutrophic lakes. Vertical profiles of dissolved-oxygen concentrations, specific conductance, and water temperature at several cross sections in Converse Lake have helped to identify the seasonal occurrence of anoxic conditions (Journey and others, 1995; Bayne and others, 1998).

In 1995, the USGS published a report that describes streamflow and nutrient contributions of major tributaries to Converse Lake (Journey and others, 1995). Nutrient loads to the lake were computed for 1991 and 1992. Big Creek and Hamilton Creek were estimated to have the highest nitrogen loads. Crooked and Juniper Creeks also had relatively high nitrogen loads compared to Collins Creek, an adjacent tributary basin with similar drainage area and land use. Big Creek, Crooked Creek, and Hamilton Creek subbasins contributed the highest phosphorus loads, and these subbasins also had a variety of land-use practices, such as pastures, plant nurseries, and residential areas.

In its two water-treatment plants, the MAWSS monitors raw and finished water for microbial contaminants and disinfection by-products in compliance with the 1996 amendments to the Safe Drinking Water Act: Information Collection Rule and the Enhanced Surface Water Treatment Rule (U.S. Environmental Protection Agency, 1996a,b,c). In 1995, concentrations of total organic carbon (TOC) periodically increased in raw and finished water at both treatment facilities. The treatment of the increased TOC concentrations resulted in higher concentrations of disinfection by-products in the finished water. In 1995, the sources of the periodic increases in TOC were not understood. 


\section{WATERSHED CHARACTERIZATION}

Converse Lake was formed from the impoundment of Big Creek in 1952 and was previously known as Big Creek Lake. The drainage area of the watershed is $103 \mathrm{mi}^{2}$ at the dam (table 2). The lake volume is 52,000 acre- $\mathrm{ft}$, or approximately 17 billion gallons of water at the normal operational pool level of $110 \mathrm{ft}$ above mean sea level (City of Mobile, Board of Water and Sewer Commissioners, written commun., October 5, 1994). Converse Lake has a mean depth of $14.4 \mathrm{ft}$ at full pool, with maximum depths of over $50 \mathrm{ft}$ near the dam and spillway (table 2). The pump station is located in a small embayment below the mouth of Hamilton Creek (site LHAM, fig. 1). The embayment has a maximum depth of $27 \mathrm{ft}$.

Table 2. Physical characteristics of Converse Lake

\begin{tabular}{lc}
\hline \multicolumn{1}{c}{ Characteristic } & Value \\
\hline Total volume & 52,000 acre-feet \\
Surface area & 3,600 acres \\
Mean depth & 14.4 feet \\
Maximum depth & $50+$ feet \\
Mean annual inflow & 163 cubic feet per second \\
Hydraulic residence time & 0.44 year \\
& 160 days \\
Drainage area of watershed & 103 square miles \\
\hline
\end{tabular}

The Converse Lake watershed is located in Mobile County west of the city of Mobile near the Alabama-Mississippi State line. The lake is designated by the ADEM for aquatic life and public water-supply use (Alabama Department of Environmental Management, 1994b). Management of the lake requires an understanding of all factors influencing the water quality. A sound science-based management plan for development and growth in the watershed considers all aspects of naturally occurring and culturally induced factors in order to aid in the protection of the water quality of the lake and its tributaries.

For this investigation, spatial coverages of natural and cultural features in the watershed were obtained from geographic information system (GIS) databases. ArcInfo and ArcView 3.2 GIS coverages were developed and used to integrate the information on environmental factors and water quality. The coverages include basin and major tributary subbasin drainage areas (1:24,000 scale); streams, roads, railroads, and major geologic units (1:250,000 scale); major soil types (State Soil Geographic [STATSGO] database, 1:250,000 scale); Landsat satellite imagery of major land use and land cover (1992 Multi-Resolution Land Characteristics [MRLC], 30-meter resolution); and locations of point sources in the watershed (U.S. Environmental Protection Agency [USEPA] Toxic Release Inventory [TRI], hazardous-waste permit compliance system [PCS], and Superfund [Comprehensive Environmental Response, Compensation, and Liability Act-CERCLA] sites). Spatial differences in water quality were compared to the spatial coverage of environmental factors to identify potential relations. This integrated approach helped identify key factors that influence water quality, and evaluate the present conditions in the lake and its tributaries.

\section{Natural Factors}

The interaction of many environmental factors affects the quality of the water in a watershed. Some natural factors in a watershed, such as climate, topography, rock and soil types, and vegetation, can influence water quality differently.

\section{Climate}

The study area is close to the Gulf Coast and, thus, the climate is subtropical. Precipitation occurs almost exclusively as rainfall. Snowfall accumulation is rare. Several types of weather patterns influence the climate. The Gulf of Mexico produces warm, humid air masses that move inland and provide precipitation in the form of sporadic thunderstorms, especially during the summer. Extremely high-intensity rainfall is produced from tropical systems that enter the Gulf of Mexico (tropical depressions, storms, and hurricanes) and move inland in late summer and early fall (July to September). In winter, the climate is further influenced by arctic fronts that move south from the Midwest. Frontal storms contribute more continuous precipitation and cooler temperatures.

The mean annual precipitation in the Mobile area for the 30-year period 1961-90 was $64 \mathrm{in.}$ and ranged from 44 to 86 in. (National Oceanic and Atmospheric Administration, 1998). Mean monthly precipitation ranged from 3 in. in October to 7 in. in August (fig. 2). A distinct dry period occurred during late fall (October to November). Two wet periods were identified during 


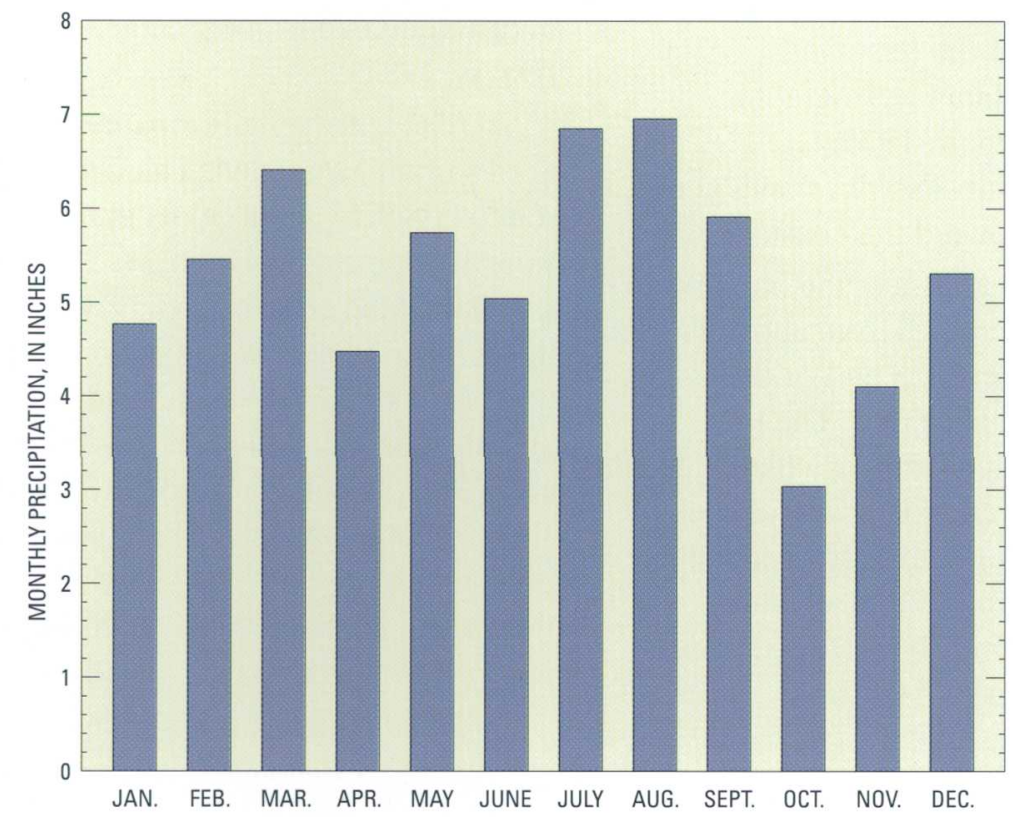

Figure 2. Mean monthly precipitation for 1961-90 at the Mobile Regional Airport, Alabama.

early spring (March) and late summer (July to August). The late summer wet period was related to tropical storms moving inland from the Gulf of Mexico.

During the study period, the driest years were 1990 and 1994 when annual precipitation was about 8 in. below the normal mean annual precipitation of 64 in. (fig. 3). The wettest years were 1991 and 1995 when annual precipitation was more than 15 in. above the normal mean annual precipitation.

The mean annual temperature during the study period was $67.5^{\circ} \mathrm{F}$. Temperatures in the study area generally are above freezing throughout most of the year, and mean monthly temperatures range from $50^{\circ} \mathrm{F}$ in January to $82^{\circ} \mathrm{F}$ in July (National Oceanic and Atmospheric Administration, 1998).

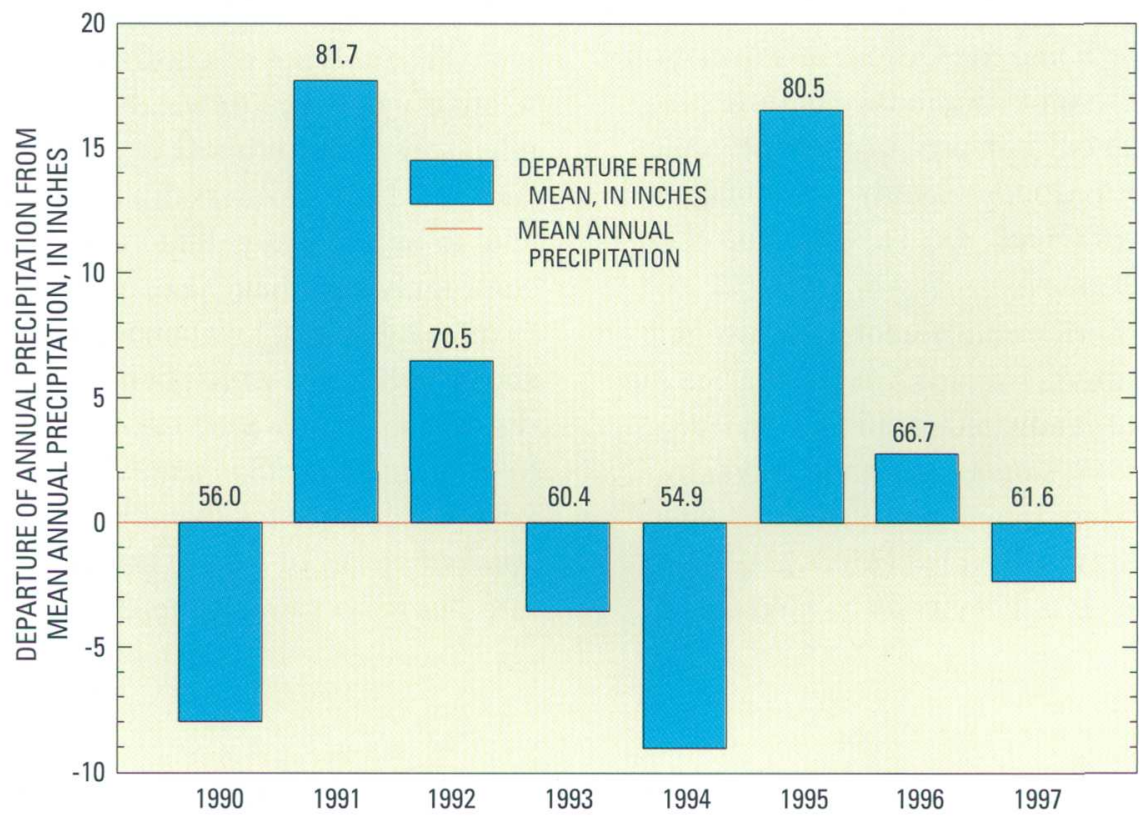

Figure 3. Total annual precipitation (1990-97) and departure from the mean annual precipitation (1961-90) of 64 inches. 


\section{Physiography}

The Converse Lake watershed lies within the Southern Pine Hills District of the East Gulf Coastal Plain section of the Coastal Plain Physiographic Province (Sapp and Emplaincourt, 1975; fig. 1). Land surface in the Southern Pine Hills District slopes gently in a southwesterly direction toward the coast.

In the Converse Lake watershed, the maximum altitude of the land surface decreases from about $290 \mathrm{ft}$ above mean sea level in the northern part of the watershed to $250 \mathrm{ft}$ in the southern part. The lowest point in the watershed is the lake surface, which has an altitude ranging between 105 and $115 \mathrm{ft}$ above mean sea level. A spatial coverage of land-surface slope for the watershed was obtained from digital elevation models (DEMs). The majority of the watershed has a gentle slope of less than 1 degree. Maximum slopes of 4 degrees are found at altitudes ranging between 150 and $200 \mathrm{ft}$ (fig. 4); steeper slopes may result from changes in lithology. Because of the steeper slopes, which allow for greater erosion and quicker transport of contaminants, this area has a greater potential for contributing contaminants to the lake and its tributaries during runoff conditions.

\section{Major Hydrogeologic Units}

Two geologic units consisting of semiconsolidated to unconsolidated sand, silt, gravel, and clay of Tertiary age underlie the Converse Lake watershed (fig. 5). The two units are undifferentiated sedimentary deposits of Miocene age (named Miocene Series undifferentiated) and the Citronelle Formation of Pliocene age. These units dip to the southwest at about $5 \mathrm{ft} / \mathrm{mi}$ near the outcrop area of the Citronelle Formation in northern Mobile County to as much as $50 \mathrm{ft} / \mathrm{mi}$ near the coast (Reed, 1971). The units also thicken to the southwest.

The Miocene Series undifferentiated, which is the older of the two units, is marine and estuarine in origin and consists of laminated to thinly bedded, laterally extensive clays, sands, and sandy clays (fig. 6; Reed, 1971). The texture ranges from fine to coarse sands that are locally cross bedded (Mooty, 1988). Some outcrops of this unit have beds of sand that contain gravel and petrified plant fossils, and clays that contain carbonized leaf remains. The Miocene Series undifferentiated is about $3,000 \mathrm{ft}$ thick near the coast (Davis, 1987).

The Citronelle Formation overlies the Miocene Series undifferentiated. The Citronelle Formation is relatively thin (about $30 \mathrm{ft}$ ) in the northern part of the watershed, but thickens toward the south to about $130 \mathrm{ft}$ near the coast (fig. 6; Davis, 1987). Sediments of this unit consist of gravelly sands and sandy clays. Thin ( 5 to $15 \mathrm{ft}$ thick) lenses of sandy clay and clayey sand are interbedded with gravelly sand in some areas of the unit. The base of the Citronelle Formation has a high clay and iron content and includes limonite-cemented (iron hydroxide) gravelly sand. The Citronelle Formation grades into discontinuous, sandy-clay and clayey-sand lenses interbedded with gravelly sand.

The major aquifer system contributing ground water to the streams and lakes in the Converse Lake watershed is the Pliocene-Miocene aquifer, which consists of the Citronelle Formation (of Pliocene age) and the Miocene Series undifferentiated (Mooty, 1988). Although clayey sediments in the Miocene Series cause the aquifer to behave as if it were semiconfined at depth, the sand and gravel beds of the Citronelle Formation and upper part of the Miocene Series are hydraulically connected to the land surface. As a result, ground water is susceptible to contamination from the watershed surface. Areas in the watershed most susceptible to contamination from the surface are those that are relatively flat with very permeable soils.

These types of clastic sediments tend to be relatively resistant to weathering and contribute relatively little to runoff or surface-water chemistry (Drever, 1988). Waters draining resistant sediments tend to be relatively dilute in total dissolved solids, commonly less than $100 \mathrm{mg} / \mathrm{L}$. The dilute waters tend to have relatively low concentrations of base cations and bicarbonate, which help to neutralize acid. As a result, the $\mathrm{pH}$ of waters draining clastic sediments tend to be more acidic than waters draining other rock types. Also, the iron-rich cement in the sediment can elevate concentrations of iron in the ground water, which in turn discharges to streams and lakes. 


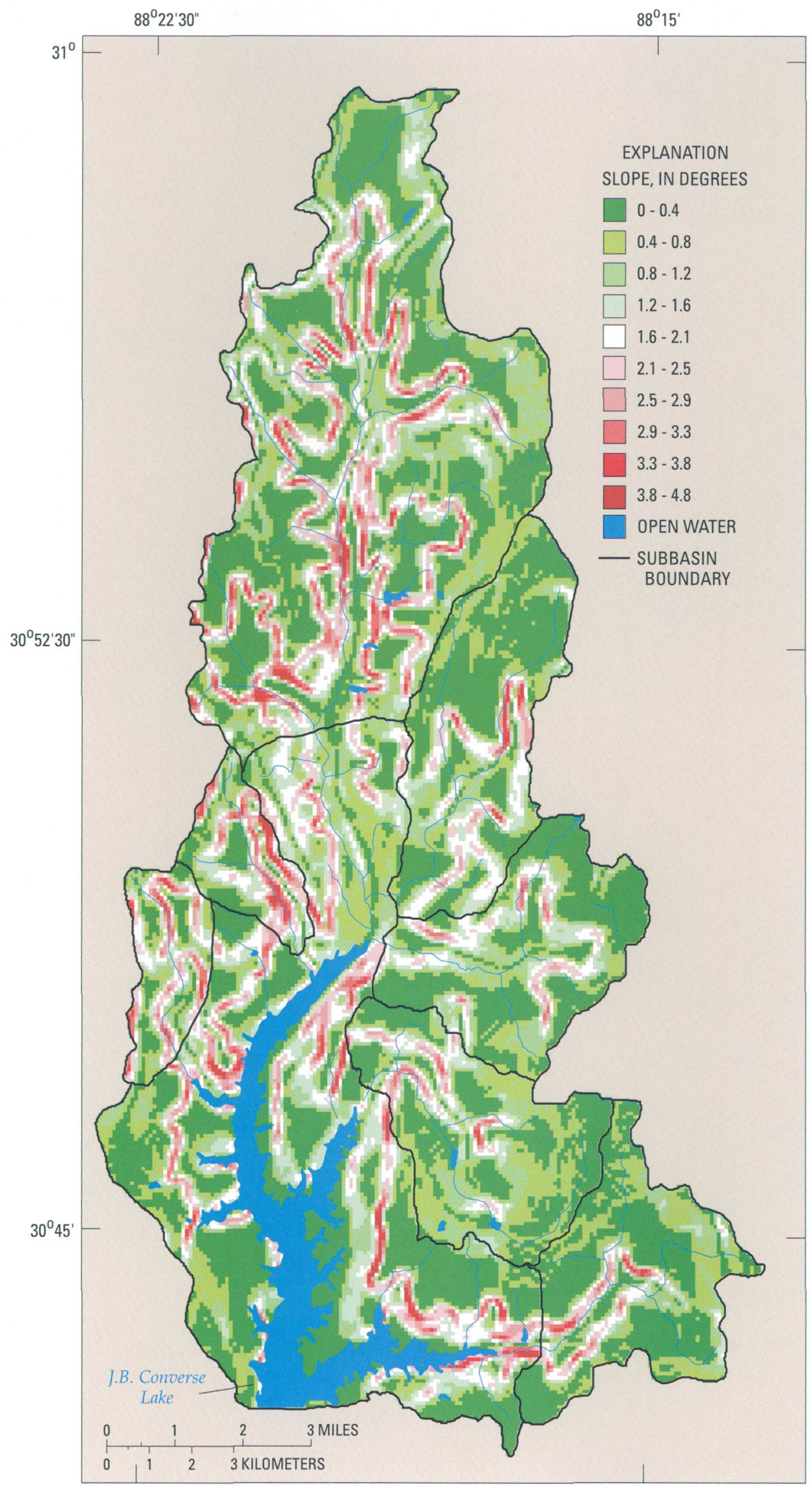

Figure 4. Digital elevation model (DEM) coverage of land-surface slope in subbasins of the Converse Lake watershed, Alabama. 


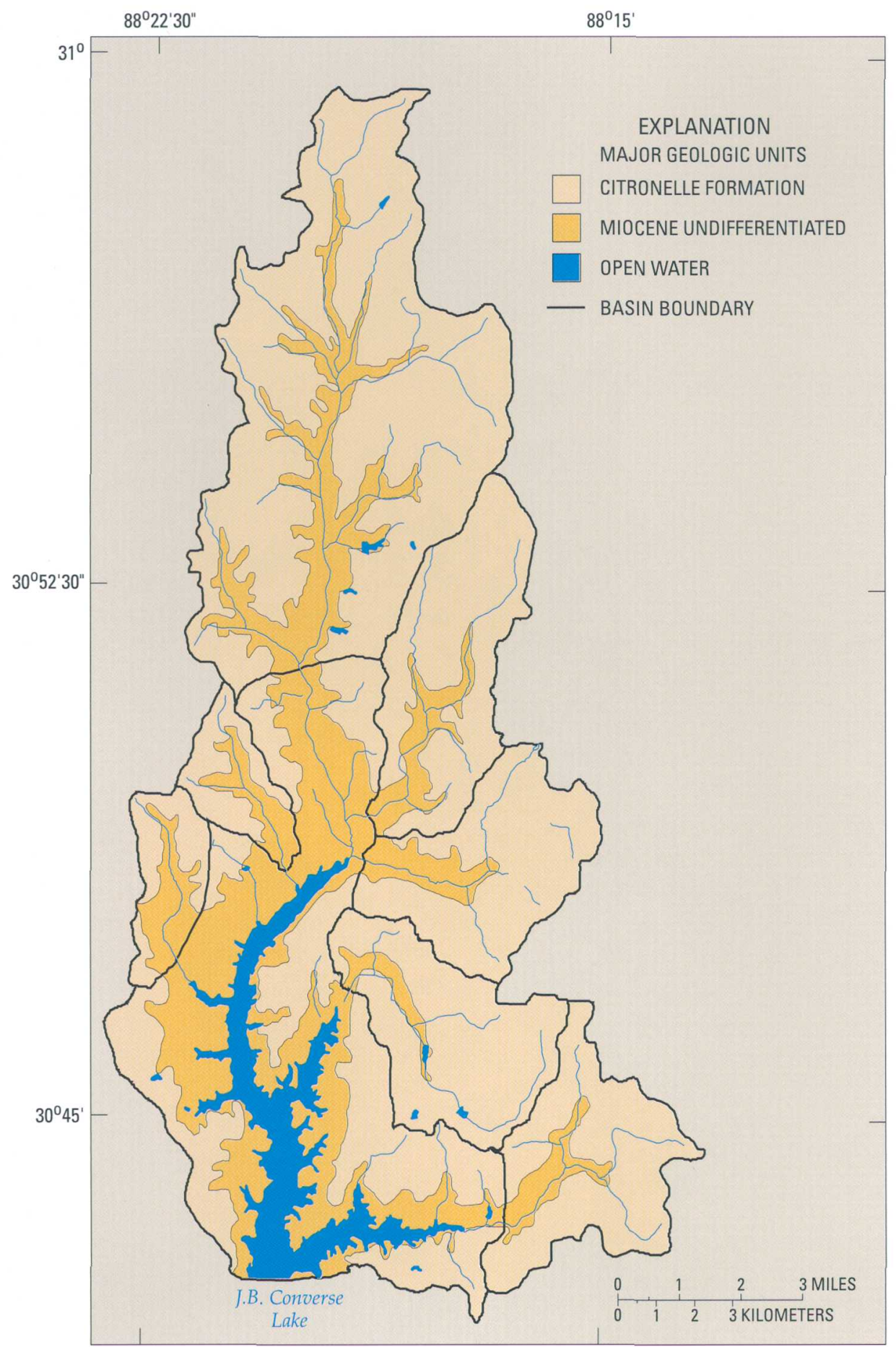

Figure 5. Major geologic units in the Converse Lake watershed, Alabama. 


\begin{tabular}{|c|l|l|c|l|l|l|l|}
\hline System & Series & Geologic unit & $\begin{array}{c}\text { Thickness } \\
\text { (feet) }\end{array}$ & \multicolumn{1}{|c|}{ Lithology } & Aquifer & \multicolumn{1}{|c|}{$\begin{array}{c}\text { Quality of } \\
\text { ground water }\end{array}$} \\
\hline & Pliocene & $\begin{array}{l}\text { Citronelle } \\
\text { Formation }\end{array}$ & $0-130$ & $\begin{array}{l}\text { Sand, brown, red, } \\
\text { and orange, fine- to } \\
\text { coarse-grained, } \\
\text { gravelly in places; } \\
\text { contains clay balls } \\
\text { and partings; gray, } \\
\text { orange, and brown } \\
\text { lenticular sandy } \\
\text { clay, ferruginous } \\
\text { sandstone. }\end{array}$ & $\begin{array}{l}\text { Pliocene- } \\
\text { Miocene } \\
\text { aquifer }\end{array}$ & $\begin{array}{l}\text { Will yield 2 million } \\
\text { gallons of water } \\
\text { per day or more } \\
\text { per well. }\end{array}$ & $\begin{array}{l}\text { Water is low in total } \\
\text { dissolved solids, } \\
\text { contains iron in } \\
\text { excess of 0.3 milli- } \\
\text { gram per liter, and } \\
\text { acidic. }\end{array}$ \\
\cline { 2 - 5 } & Miocene & $\begin{array}{l}\text { Miocene } \\
\text { Series } \\
\text { undifferentiated }\end{array}$ & $30-3,000$ & $\begin{array}{l}\text { Sand, gray, orange, } \\
\text { and red, very fine- } \\
\text { to coarse-grained, } \\
\text { contains gravel in } \\
\text { places; gray thin- } \\
\text { bedded to massive } \\
\text { sandy silty clay. }\end{array}$ & & \\
\hline
\end{tabular}

Figure 6. Stratigraphy and lithology of the geologic units and water-bearing properties in the Converse Lake watershed, Alabama.

\section{Major Soil Types}

The type of soil in a particular region is influenced by climate, the nature of the bedrock, landscape relief, vegetation, and the time over which the soil-forming process occurs. These factors interact to produce characteristic soil profiles that vary with depth and complexity. The major soil type in the Converse Lake watershed is classified as ultisol (Hajek and others, 1975). These deeply weathered soils are common in the Southeast because of the humid climate.

The State Soil Geographic (STATSGO) database for Alabama contains digital geographic data created by generalizing more detailed soil survey maps onto USGS 1:250,000-scale topographic quadrangle series maps (U.S. Department of Agriculture, 1994). This database provides soil types in a particular area on a regional scale. Four major soil associations are present in the Converse Lake watershed (fig. 7)-TroupSmithton-Bibb (AL 213), Troup-Heidel-Bama (AL 221), Notcher-Saucier-Malbis (AL 223), and Esto-Troup-Benndale (AL 226). The Troup-Heidel-

Bama soil series covers 77.8 percent of the watershed. The Troup-Smithton-Bibb soil series covers 21.3 percent of the watershed, all of which is in the Big Creek subbasin. The major soil associations of Notcher-Saucier-Malbis and Esto-Troup-Benndale account for less than 1 percent of the watershed's soil cover.

\section{Each soil series has certain properties or} characteristics associated with it. All of the major soils are deep and highly acidic (Hajek and others, 1975). Troup, Benndale, and Bama soil series are classified as well drained with moderate permeability. Smithton soil series is poorly drained with moderately slow permeability, and potentially has a perched water table. Malbis soil series is moderately well drained and tends to have a perched water table.

\section{Hydrology}

Understanding the hydrologic cycling of water in the Converse Lake watershed is necessary to identify the potential and actual sources of contaminants to the lake and its tributaries. Ground water in the surficial aquifer system discharges to the lake and its tributaries. Contaminants can infiltrate from the land surface into the ground water in the surficial aquifer. Ground water then can be a source of contamination to the lake and tributaries. The tributaries supply varying amounts of annual inflow to the lake, carrying loads of nutrients, bacteria, and organic carbon. The ability of the lake to assimilate the contaminant loads is, in part, related to the amount of inflow to and outflow from the lake. The 


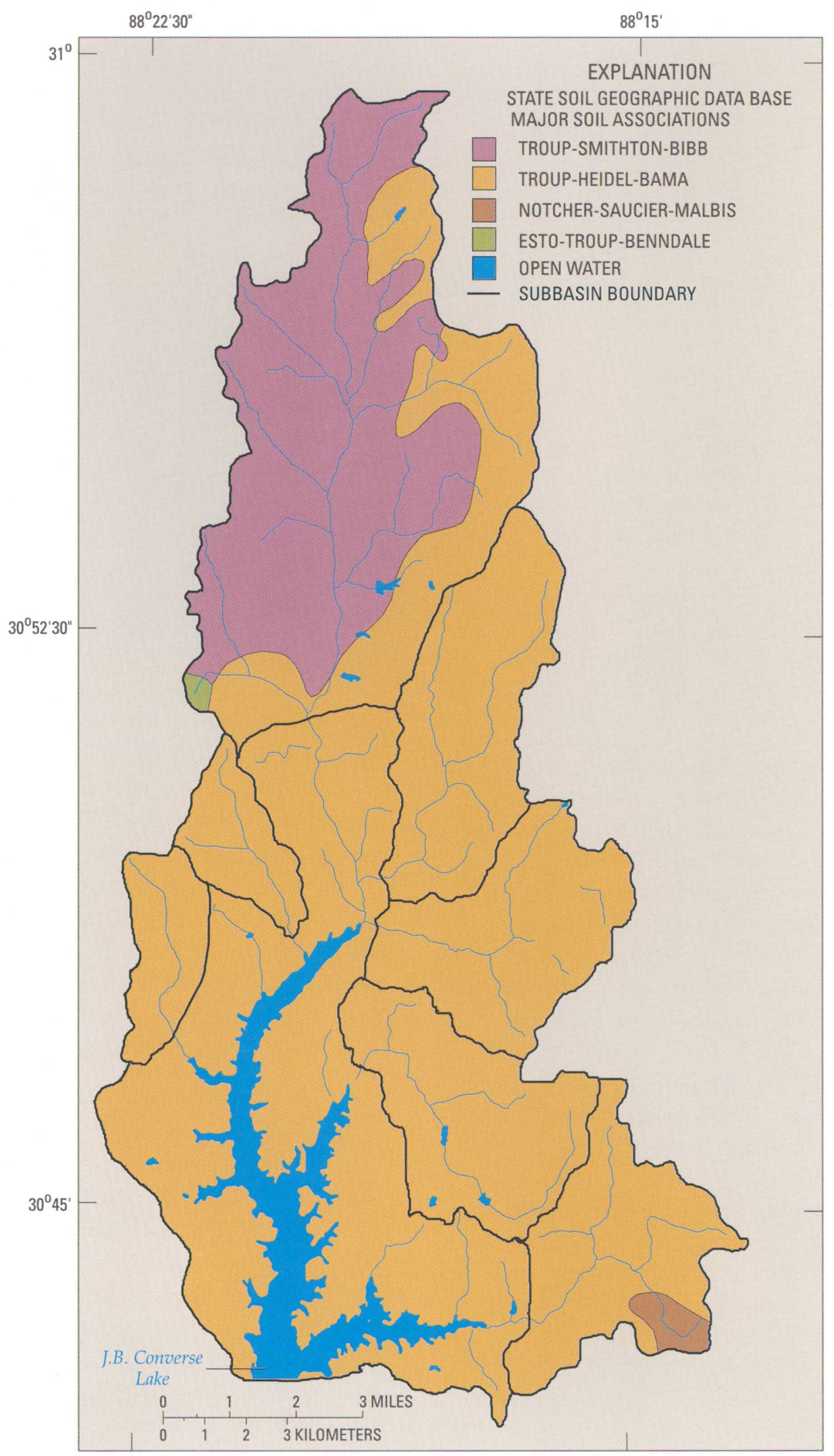

Figure 7. Major soil associations in the Converse Lake watershed, Alabama. 
inflow to and outflow from the lake determines the residence time of the water in the lake.

Converse Lake receives inflow from seven major tributaries that drain about three-fourths of the total watershed (fig. 1; table 1). Big Creek is the largest subbasin and drains $31.5 \mathrm{mi}^{2}$ at the Big Creek gaging station (site BIG, fig. 1) near Wilmer, Ala. Adjoining subbasins in the eastern part of the watershed are Juniper Creek (site JUN), Collins Creek (site COL), Crooked Creek (site CRO), and Hamilton Creek (site HAM; fig. 1). These subbasins have drainage areas ranging from 8.08 to $9.22 \mathrm{mi}^{2}$. Long Branch (site LON) and Boggy Branch (site BOG; fig. 1), located in the western part of the watershed, have smaller subbasins that each drain about $3 \mathrm{mi}^{2}$ (table 1).

Streamflow data are critical in computing and interpreting nutrient loads and trends. A brief summary of streamflow conditions in the Converse Lake watershed for the study period, October 1990 to September 1998, is provided in table 3. Long and Boggy Branches (sites LON and BOG) had only 1 year of record; Collins and Juniper Creeks (sites COL and JUN) had 2 years of record. Big Creek, Crooked Creek, and Hamilton Creek (sites BIG, CRO, and HAM) had mean annual streamflows of 72.2, 19.4, and $25.0\left(\mathrm{ft}^{3} / \mathrm{s}\right)$, respectively, for the study period.
Computation of annual yields was used to normalize streamflow for the tributary drainage areas to allow for comparisons of streamflow per square mile. Hamilton Creek subbasin had the greatest yield of $3.04\left(\mathrm{ft}^{3} / \mathrm{s}\right) / \mathrm{mi}^{2}$; Crooked and Big Creeks had yields of 2.40 and $2.29\left(\mathrm{ft}^{3} / \mathrm{s}\right) / \mathrm{mi}^{2}$, respectively.

Big Creek contributes about one-half of the gaged inflow to Converse Lake during average and above-average flow conditions, and Hamilton Creek contributes about 20 percent (Journey and others, 1995). Hamilton Creek, however, has more sustained flows, and the proportion of its contribution to the total inflow increases as overall flow decreases. Crooked, Collins, and Juniper Creeks also contribute substantial inflow to the lake, especially during low-flow periods. Long and Boggy Branches seldom contribute more than 10 percent of the total inflow to the lake under all flow conditions (table 3). Downstream from the dam, Big Creek continues to flow to the south-southwest to its confluence with the Escatawpa River in Mississippi.

Streamflow frequency can be estimated by constructing a flow-duration curve for the stream. By definition, the flow-duration curve is a cumulativefrequency curve that shows the percentage of time a specific streamflow is equaled or exceeded during a given period. The shape of the flow-duration curve is a

Table 3. Streamflow conditions in selected tributaries to Converse Lake, October 1990 to September 1998 $\left[\mathrm{mi}^{2}\right.$, square miles; $\mathrm{ft}^{3} / \mathrm{s}$, cubic feet per second; - , not applicable]

\begin{tabular}{|c|c|c|c|c|c|c|c|c|c|}
\hline \multirow[b]{2}{*}{$\begin{array}{c}\text { Site } \\
\text { label } \\
\text { (fig. 1) }\end{array}$} & \multirow[b]{2}{*}{$\begin{array}{l}\text { Station } \\
\text { number }\end{array}$} & \multirow[b]{2}{*}{ Station name } & \multirow[b]{2}{*}{$\begin{array}{c}\text { Drainage } \\
\text { area } \\
\left(\mathrm{mi}^{2}\right)\end{array}$} & \multirow[b]{2}{*}{$\begin{array}{l}\text { Period of } \\
\text { record }\end{array}$} & \multicolumn{5}{|c|}{ Streamflow characteristics, $\left(\mathrm{ft}^{3} / \mathrm{s}\right)$} \\
\hline & & & & & $\begin{array}{l}\text { Mean } \\
\text { annual }\end{array}$ & $\begin{array}{c}1991 \\
\text { water } \\
\text { year }\end{array}$ & $\begin{array}{c}10 \\
\text { percent } \\
\text { exceeds }\end{array}$ & $\begin{array}{c}50 \\
\text { percent } \\
\text { exceeds }\end{array}$ & $\begin{array}{c}9 \\
\text { percent } \\
\text { exceeds }\end{array}$ \\
\hline $\mathrm{BIG}$ & 02479945 & $\begin{array}{l}\text { Big Creek at County Road } 63 \\
\text { near Wilmer, Ala. }\end{array}$ & 31.5 & 1991-98 & $72.2^{\mathrm{a}}$ & 94.1 & $147^{\mathrm{a}}$ & $40^{\mathrm{a}}$ & $22^{\mathrm{a}}$ \\
\hline JUN & 02479948 & $\begin{array}{l}\text { Juniper Creek at Glenwood } \\
\text { Road near Fairview, Ala. }\end{array}$ & 9.22 & 1991-92 & $17.7^{\mathrm{b}}$ & 20.1 & $28^{\mathrm{b}}$ & $14^{\mathrm{b}}$ & $10^{\mathrm{b}}$ \\
\hline $\mathrm{COL}$ & 02479950 & $\begin{array}{l}\text { Collins Creek at Glenwood } \\
\text { Road near Fairview, Ala. }\end{array}$ & 8.54 & 1991-92 & $15.7^{\mathrm{b}}$ & 18.1 & $24^{b}$ & $13^{b}$ & $9.2^{\mathrm{b}}$ \\
\hline LON & 02479955 & $\begin{array}{l}\text { Long Branch near Wilmer, } \\
\text { Ala. }\end{array}$ & 2.85 & 1991 & - & $6.76^{\mathrm{c}}$ & 一 & - & - \\
\hline BOG & 02479960 & $\begin{array}{l}\text { Boggy Branch near Wilmer, } \\
\text { Ala. }\end{array}$ & 3.17 & 1991 & - & $9.43^{\mathrm{c}}$ & - & - & - \\
\hline $\mathrm{CRO}$ & 02479980 & $\begin{array}{l}\text { Crooked Creek near } \\
\text { Fairview, Ala. }\end{array}$ & 8.08 & 1991-98 & $19.4^{\mathrm{a}}$ & 21.8 & $29^{\mathrm{a}}$ & $12^{\mathrm{a}}$ & $8.4^{\mathrm{a}}$ \\
\hline \multirow[t]{2}{*}{ HAM } & 02480002 & $\begin{array}{l}\text { Hamilton Creek at Snow } \\
\text { Road near Semmes, Ala. }\end{array}$ & 8.22 & $1991-98$ & $25.0^{\mathrm{a}}$ & 24.5 & $33^{\mathrm{a}}$ & $18^{\mathrm{a}}$ & $13^{\mathrm{a}}$ \\
\hline & & TOTAL & 71.58 & - & - & 196 & - & - & - \\
\hline
\end{tabular}

a Data published in Pearman, Stricklin, and Psinakis (1998).

${ }^{b}$ Data published in Pearman and others (1992).

${ }^{\mathrm{c}}$ Data published in Pearman and others (1991). 
reflection of the hydrologic and geologic characteristics of the stream's watershed (Searcy, 1959). A flow-duration curve that has a steep slope is indicative of a stream having highly variable flow derived largely from direct runoff (little or no groundwater contribution); a flat slope is indicative of sustained flow, a result of contributions from surfaceor ground-water storage. During dry periods, when streamflow is at a minimum, water discharging to streams and lakes is considered to be derived almost solely from ground water.

Flow-duration curves were constructed from continuous streamflow record for the period October 1990 to September 1998 for three gaged sites in the Converse Lake watershed-Big Creek (site BIG), Crooked Creek (site CRO), and Hamilton Creek (site HAM, figs. 1, 8). Because the drainage areas of the selected streams vary, the computed values were normalized to obtain unit-area discharge in cubic feet per second per square mile. Hamilton Creek had the greatest sustained streamflow of the selected sites, but flow duration at all sites indicated that ground water is an important contributor of water to Converse Lake and its tributaries during periods of no rainfall.

For this investigation, mean annual inflow was estimated for October 1990 to September 1998 based on streamflow data for Big Creek, Crooked Creek, and Hamilton Creek (sites BIG, CRO, and HAM; fig. 1). Because of limited streamflow record at the remaining four sites (table 3), streamflow data for these sites were not used in the calculation. Based on the 1991 water year in which streamflow data were available for all seven sites, Big Creek, Crooked Creek, and Hamilton Creek contributed 72 percent of the total annual inflow to the reservoir. The mean annual inflow to the reservoir for the 1990-98 period was estimated by combining the mean annual streamflow for Big Creek, Crooked Creek, and Hamilton Creek $\left(117 \mathrm{ft}^{3} / \mathrm{s}\right)$ and multiplying by 1.39 (the reciprocal of 72 percent). The product $\left(163 \mathrm{ft}^{3} / \mathrm{s}\right)$ was converted to acre-ft by multiplying by 724 acre-ft per year to obtain a mean annual inflow to the reservoir of about 118,000 acre-ft. The residence time of water in a reservoir is calculated by dividing the volume of the reservoir (in the case of

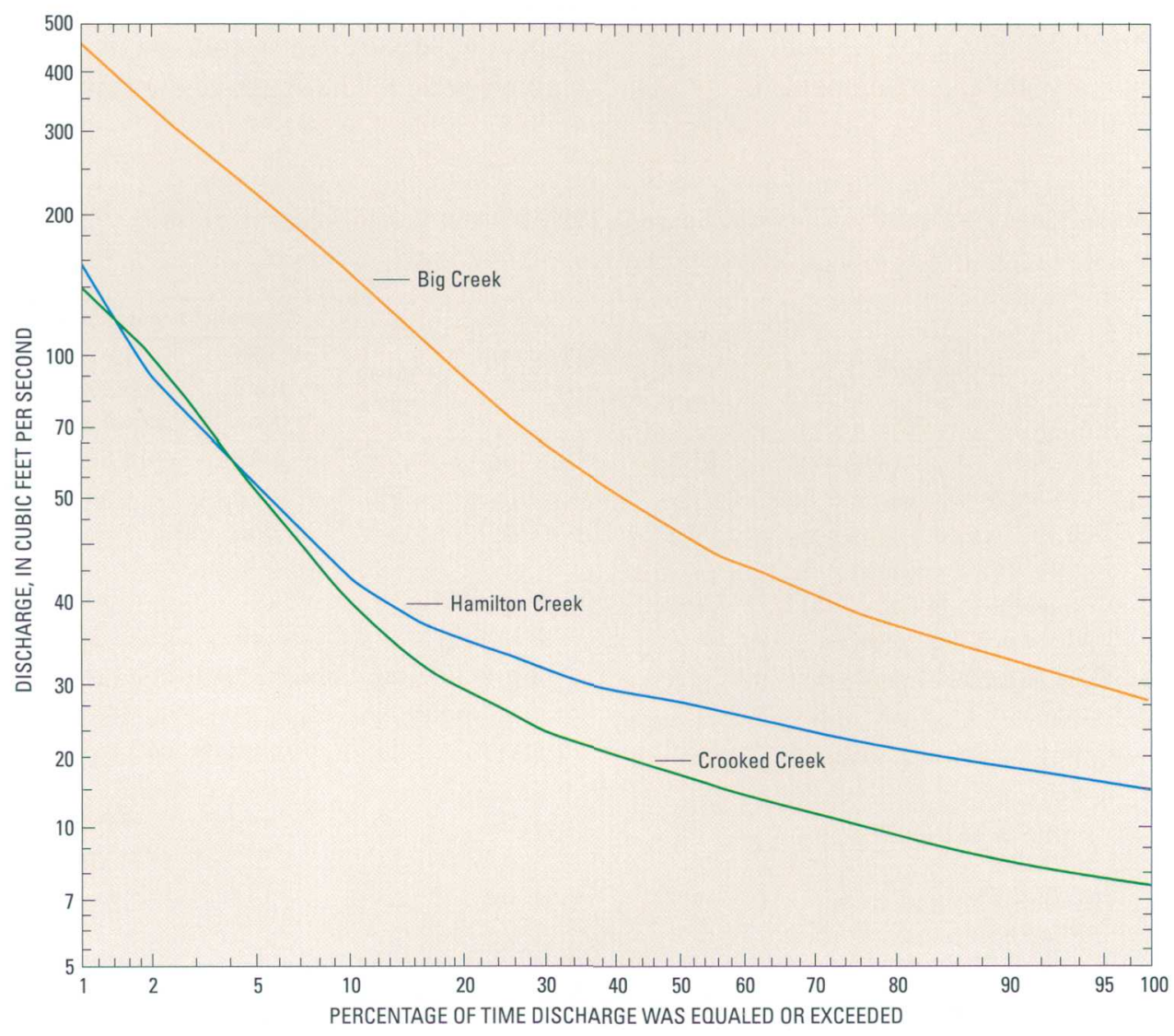

Figure 8. Streamflow duration curves for Big Creek, Crooked Creek, and Hamilton Creek in the Converse Lake watershed, 1990-98. 
Converse Lake, 52,000 acre-ft) by the mean annual inflow to the reservoir. The residence time for water in Converse Lake was calculated to be 0.44 year or 160 days (table 2 ).

\section{Cultural Factors}

Other factors influencing the water quality of Converse Lake are cultural factors derived from human activities. Cultural factors in the watershed commonly are linked to natural factors, such as land use and land cover. For example, the degree to which agricultural activities within a given watershed will affect the water quality in the watershed depends on several natural factors, such as amount of precipitation, type and thickness of soils, land-surface slope, and the amount of vegetation left to form a buffer between the developed land and water bodies in the watershed.

The rural countryside of the Converse Lake watershed is covered mainly by forests of evergreen, deciduous, and mixed deciduous/evergreen trees (64 percent of the land use in the watershed) (figs. 9, $10)$. Timber is harvested usually by clear-cutting techniques, especially in the northern part of the watershed. Agriculture accounts for about 31 percent of the land use in the watershed and is separated into two categories-pasture land and hay (18 percent) and row crops or plant nurseries (13 percent). Residential and commercial development account for only 1 percent of the total land use in the watershed. Most of the residential land use in the watershed is categorized as low-intensity development, which means that impervious areas and construction materials account for 30-80 percent of the total area, and vegetation (trees, other grasses) accounts for the remaining 20-70 percent.

Land use varies within the tributary subbasins of the Converse Lake watershed (table 4). Nearly threefourths of the Big Creek subbasin is covered by forested land. The remaining one-fourth is mainly agricultural land. The percentage of agricultural land use (row crops and pasture/hay) is greatest in the Crooked Creek subbasin, accounting for over 42 percent of the subbasin. Much of the land designated as row crops in the Crooked Creek subbasin actually is plant nurseries. The percentage of residential area (3.4 percent) in Crooked Creek is second only to Hamilton Creek (3.9 percent). The Hamilton Creek subbasin also has the greatest wetland coverage (5.3 percent) and relatively high agricultural land use (36.1 percent).

Previous work conducted by Auburn University relied on Landsat Thematic Mapper satellite images for 1984, 1992, and 1995 to identify changes in land use in the Converse Lake watershed over time (Reutebuch and others, 1997). The most dramatic change was a net regrowth of forest cover from 1984 to 1992, followed by a net loss of forest in 1995. Minimal change was observed in agricultural practices (grasslands and row crops). It should be noted, however, this method of land-use identification works best for large-scale changes in land use. Small-scale changes may be missed, as indicated by field verification that identified the presence of new homes and greenhouses in the Converse Lake watershed that were at a scale below the 30-m resolution of the satellite data.

Point-source discharges from industrial activity are monitored by State and Federal regulatory agencies. The USEPA Storage and Retrieval System (STORET) database contains all permitted pointsource locations and descriptions in the United States. This database was queried to identify point sources in the Converse Lake watershed (fig. 11). No Toxic Release Inventory (TRI) or Superfund (CERCLA) sites were present in the watershed during 1990-98. Two hazardous- and solid-waste sites were identified-one in the Hamilton Creek subbasin and the other in the Juniper Creek subbasin (fig. 11). No contaminant releases (air, water, ground water) were reported from 1987 to 1995 . Two permit compliance system (PCS) sites also were listed-one is permitted to discharge to the ground water near an unnamed tributary in the Collins Creek subbasin, and the other is permitted to discharge to the ground water near the headwaters of Hamilton Creek. No PCS discharges were reported between 1991 and 1995.

Plant nurseries ranging in size from less than an acre to over 300 acres increased in number and size in Crooked Creek and Hamilton Creek subbasins during the study period (fig. 11). The MRLC coverage does not distinguish nurseries from row crops and pastures. The Mobile County Extension Service of the Natural Resource Conservation Service (NRCS) provided location and acreage data for plant nurseries within the Converse Lake watershed that were used to develop a point coverage. The coverage shown in figure 11 demonstrates the concentration of plant nurseries in the Crooked Creek and, to a lesser extent, Hamilton Creek subbasins. 


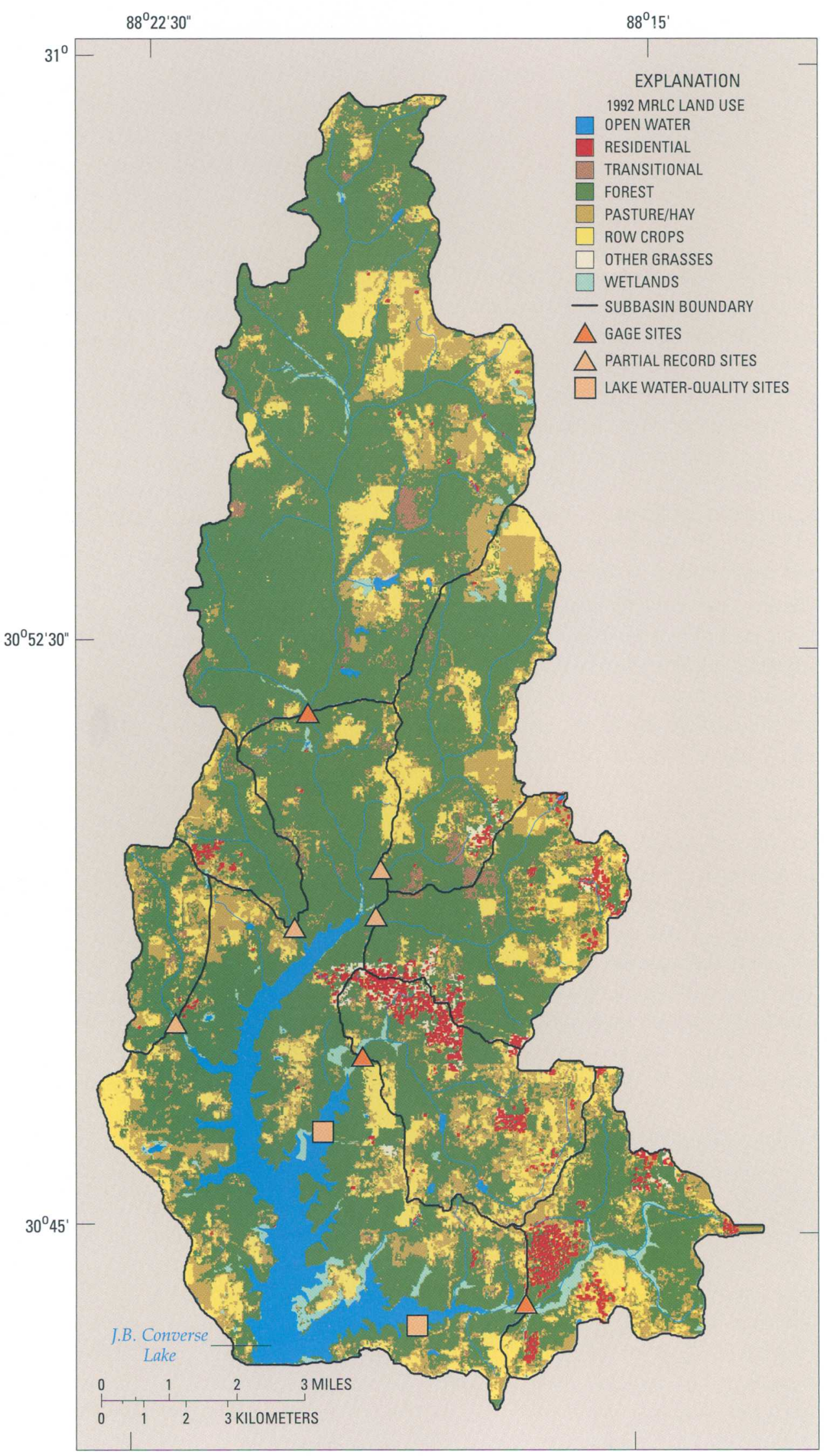

Figure 9. General land uses for the Converse Lake watershed, 1992. 


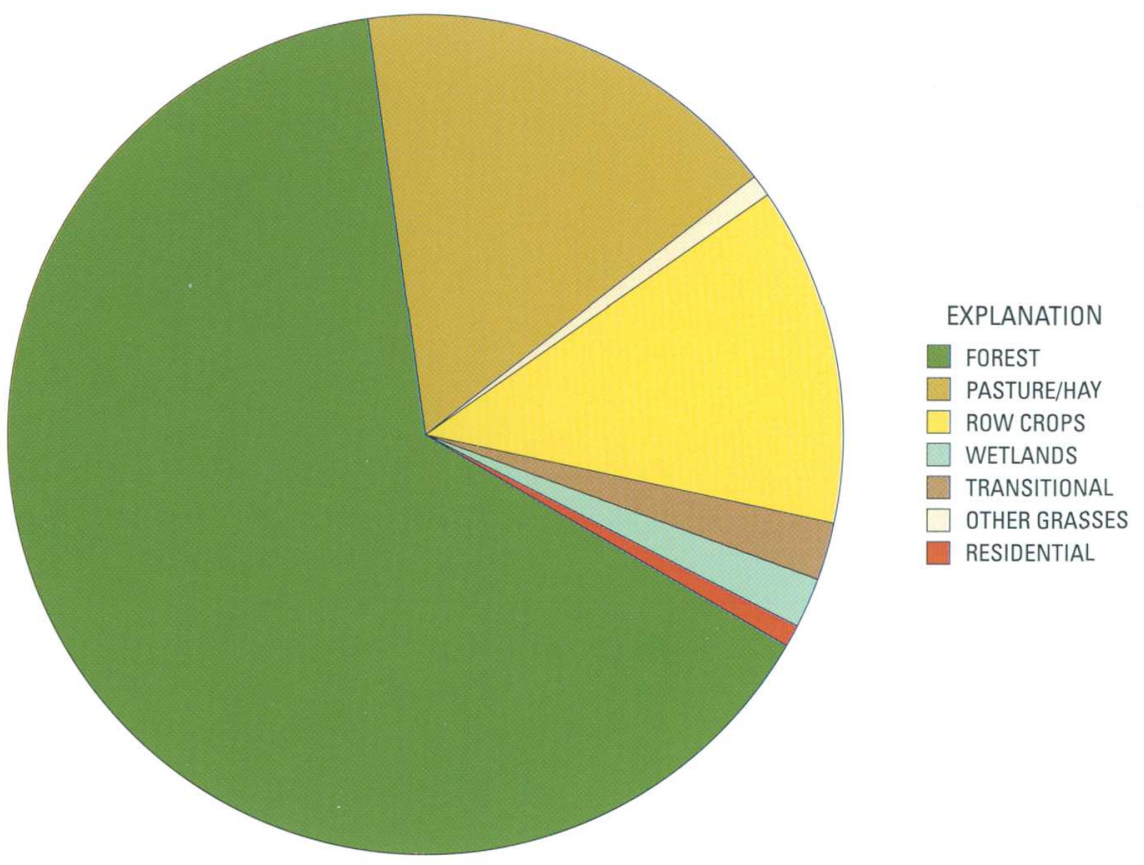

Figure 10. Land-use percentages in the Converse Lake watershed, 1992.
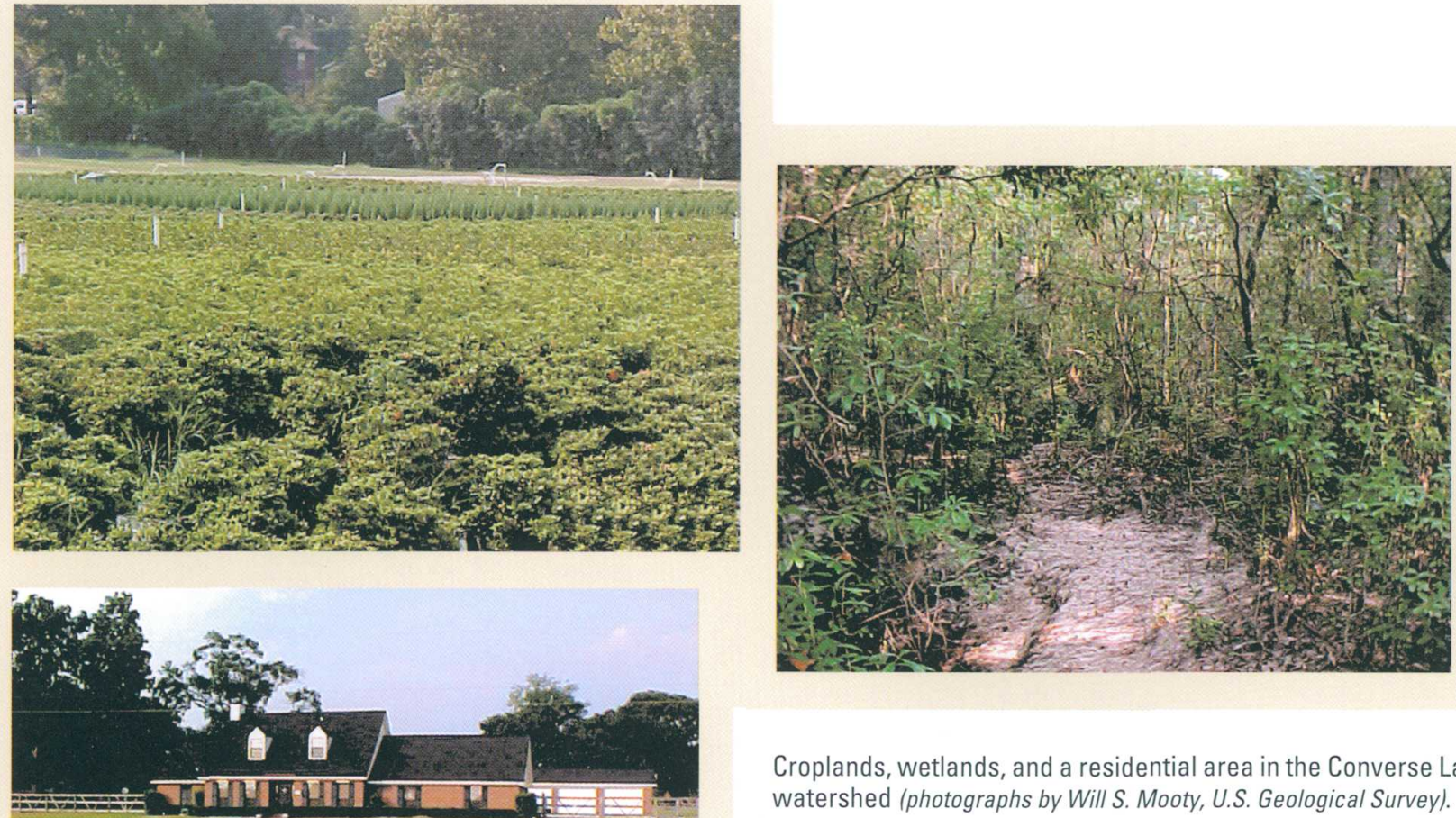

Croplands, wetlands, and a residential area in the Converse Lake watershed (photographs by Will S. Mooty, U.S. Geological Survey). 


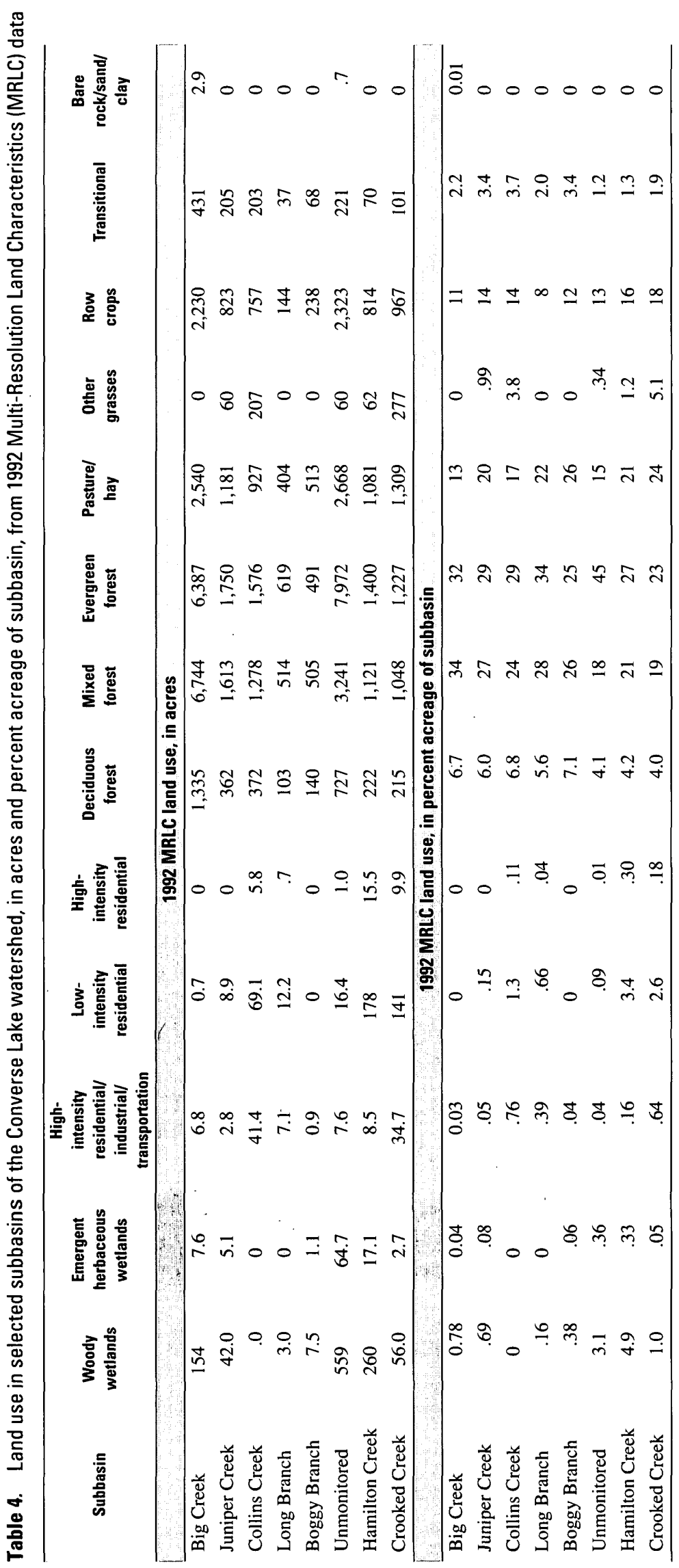




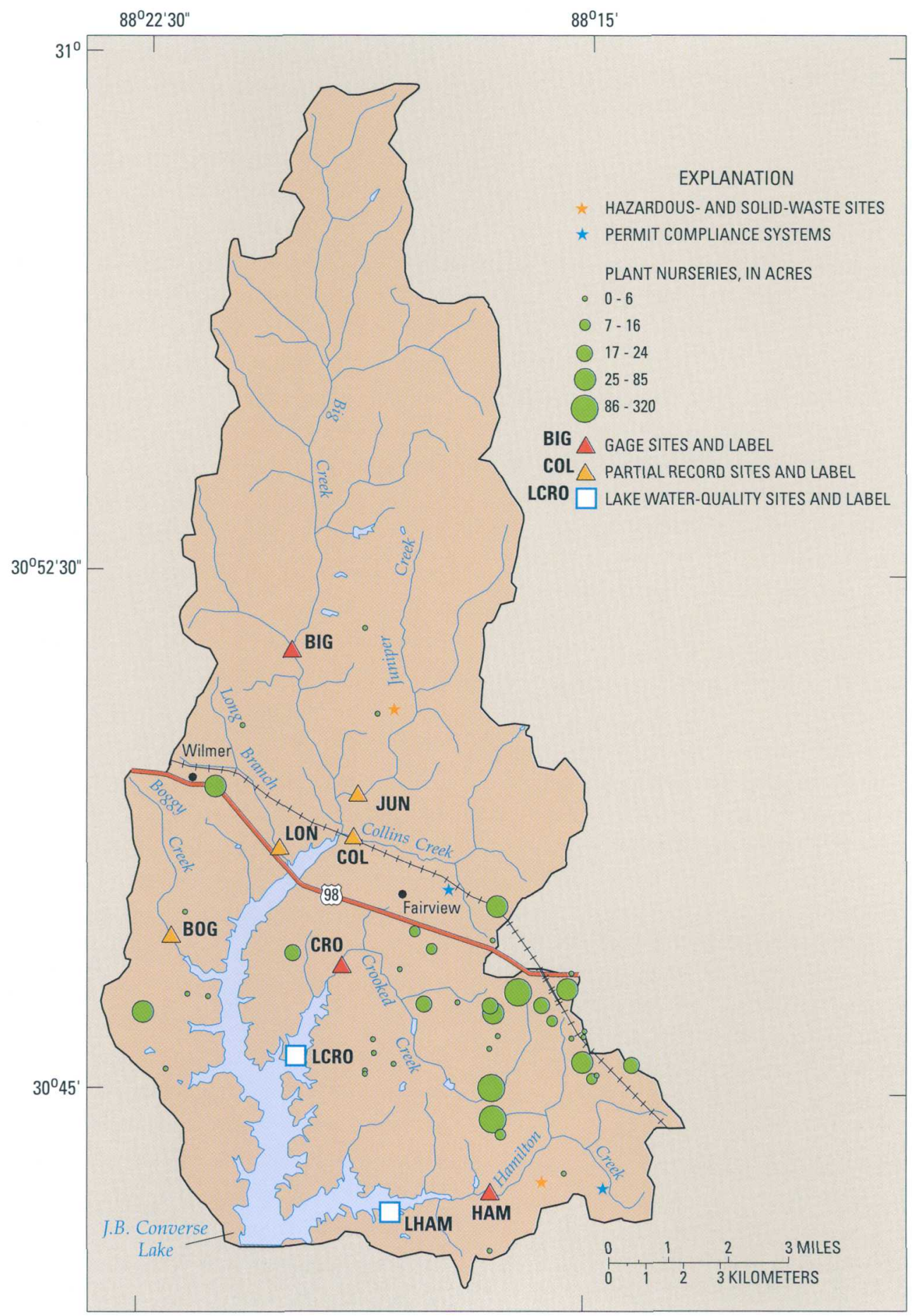

Figure 11. Locations of permitted point sources and plant nurseries in the Converse Lake watershed, 1997. 


\section{BASIC WATER CHEMISTRY}

The major dissolved constituents that give water its characteristic chemistry are cations (positively charged ions) of calcium, magnesium, sodium, and potassium; and anions (negatively charged ions) of chloride, sulfate, and nitrate. Dissolved silica also is a major constituent of most waters, especially in sandstone bedrock and acidic, deeply weathered soils such as those in the Converse Lake watershed. Concentrations of major dissolved ions generally are measured in parts per million or milligrams per liter.

The chemistry of natural surface waters is the result of interactions between precipitation, ground water, rocks, and soils near the Earth's surface. Human activity, however, can alter naturally occurring water chemistry by contributing additional ions, most commonly sodium and chloride. While basic cations and anions are not considered contaminants, elevated ion concentrations occurring near human activities may provide a clue to potential sources of more problematic contaminants (nutrients, trace elements, synthetic organic compounds).

The term "trace elements" relates to constituents in water at levels that generally are measured in parts per billion or micrograms per liter. Trace elements include metals, such as beryllium, cadmium, chromium, copper, lead, mercury, and nickel; and nonmetals, such as arsenic. These listed trace elements are considered priority pollutants by the USEPA because of their potential harm to humans and aquatic health at elevated concentrations. Iron and manganese are commonly occurring trace elements that are nonpriority pollutants. All trace elements can be derived from natural sources, such as rocks, soils, and ground water, as well as anthropogenic sources.

Other measures of the physical and chemical nature of water provide further information to assess the quality of the water. Specific conductance, water temperature, dissolved-oxygen concentration, and $\mathrm{pH}$ are important physical and chemical factors when assessing water-quality conditions.

\section{Water-Quality Analysis Methods and Approach}

Water-quality samples have been collected quarterly since 1991 at the tributary sites (sites BIG, JUN, COL, LON, BOG, CRO, and HAM; fig. 1) and in the lake at the pump station (site LHAM, fig. 1). Waterquality samples were collected at the tributary sites using a multiple vertical technique; a DH-81 sampler was used in wadeable water and a weighted-bottle sampler was used in unwadeable water. The lowgradient, slow flowing tributaries prevented the collection of true isokinetic samples (Wilde and others, 1999a). Water-quality samples were processed in the field according to procedures described in Wilde and others (1999b), and shipped to the USGS Quality Water Service Unit Laboratory in Ocala, Florida, for analysis. The samples were analyzed for major ions (calcium, magnesium, sodium, potassium, nitrate, chloride, sulfate, silica), and for iron, manganese, and boron. The analytical results are stored in the USGS National Water Information System (NWIS) database.

Streamflow gages provided continuous streamflow record at three tributary sites during the study period (sites BIG, CRO, and HAM; fig. 1). Instantaneous streamflow, water temperature, dissolved oxygen (concentration and percent saturation), $\mathrm{pH}$, alkalinity, and specific conductance were measured in the field at the time of sampling, according to techniques described in Wilde and Radtke (1998).

The chemical data are summarized statistically for this report in appendix 1. Computed statistics include maximum, minimum, mean, and the $95 \mathrm{th}$, 75th, 50 th, 25 th, and 5 th percentiles. The $n$th percentile is a data value that exceeds no more than $n$ percent of the data and is exceeded by no more than 100 minus $n$ percent of the data (Helsel and Hirsch, 1992). These statistics were used to construct boxplots of concentration data for constituents of interest. A "boxplot is a concise graphical summary of the data distribution, displaying the median, interquartile range (75th-25th percentile), skewness, and extreme values" (Helsel, 1987). The median values (50th percentile of the measured values) were used to compare between tributary subbasins and between tributary sites and the lakes to identify major differences in water chemistry. The data were compared graphically by using radial plots of the major ion concentrations converted to milliequivalents per liter. The relation between $\mathrm{pH}$ levels and land use (1992 MRLC land-use categories) in the watershed was determined by computing Spearman rho correlation coefficients and probability values to identify significant relations between the median $\mathrm{pH}$ and the percentage of land-use category in the watershed. 


\section{Results of Water-Quality Analysis}

The waters in Converse Lake and its tributaries have low $\mathrm{pH}$ and low specific conductance, which is typical of waters in humid climates that drain highly resistant sands and gravels (Hem, 1985; Drever, 1988; fig. 12). The basic chemistry of surface water in the Converse Lake watershed varies slightly among subbasins but basically is a calcium-sodium-chloridedominated water.

The presence of electrically charged dissolved constituents in water makes the water conductive; therefore, specific conductivity provides an estimate of the total dissolved constituents in water. In natural freshwater systems, specific conductance values near $50 \mu \mathrm{S} / \mathrm{cm}$ are considered low and indicative of watersheds draining resistant rocks (Drever, 1988). In the Converse Lake watershed, median specific conductance values ranged from 23 (site COL) to $43 \mu \mathrm{S} / \mathrm{cm}$ (site LON) during the study period (fig. 12; appendix 1).

Water is considered saturated with oxygen when its concentration is exactly equal to the expected solubility concentration at a particular temperature and air pressure. Commonly, the dissolved-oxygen concentration in water is measured in milligrams per liter, but a saturation percentage - percent ratio of the dissolved-oxygen concentration measured in the water to the saturated dissolved-oxygen concentration based on oxygen solubility-also can be used.

Photosynthesis from aquatic plants and reaeration from streamflow can raise the dissolved-oxygen concentration above saturated levels in natural waters, whereas respiration and bacterial decay of organic matter in these waters can reduce the dissolved-oxygen concentration below saturated levels. The degree of influence of these processes on dissolved-oxygen levels varies daily and seasonally. Photosynthesis dominates during the day because it requires sunlight; respiration dominates at night. Cooler temperatures in the winter allow for greater solubility of dissolved oxygen (solubility increases as temperature decreases), and increased streamflow during wet periods provides greater reaeration.

The ADEM criterion for minimum dissolvedoxygen concentration is $5 \mathrm{mg} / \mathrm{L}$ for the water-use classification in the Converse Lake watershed (Alabama Department of Environmental Management, 1994a). During this investigation, all tributary sites in the watershed had minimum dissolved-oxygen concentrations above $5 \mathrm{mg} / \mathrm{L}$ except for site BOG (fig. 1), which had a minimum dissolved-oxygen concentration of $3.7 \mathrm{mg} / \mathrm{L}$. Median dissolved-oxygen concentrations at tributary sites ranged from $6.9 \mathrm{mg} / \mathrm{L}$ (site BOG) to $8.6 \mathrm{mg} / \mathrm{L}$ (sites JUN and LON), and median saturation percentages ranged from 74 to 94 percent.

Reservoirs, such as Converse Lake, stratify thermally during the late summer months.

Stratification prevents mixing of the warmer, upper layer of water (epilimnion) with the cooler, denser, lower layer of water (hypolimnion). Because of the lack of mixing, solubility and photosynthetic processes in the upper layer, which produce dissolved oxygen, are unable to replenish the dissolved oxygen in the lower layer, resulting in a depletion of dissolved oxygen in the lower layer by respiration and decay of organic matter. Converse Lake typically becomes strongly stratified during August and September, and dissolvedoxygen concentrations generally fall below $1 \mathrm{mg} / \mathrm{L}$ at depths greater than $20 \mathrm{ft}$ (Journey and others, 1995; Bayne and others, 1998).

\section{Major lons}

Differences in the major ionic composition among subbasins were evaluated by constructing radial plots of median ion concentrations, in milliequivalents per liter, for the seven tributary sites and the two lake sites (fig. 13). These plots were used to illustrate variations in water composition by visually comparing the shape of the plots (sites with similar water compositions exhibit similar shapes) and the size of the plots (sites with the greater ionic concentrations exhibit larger sizes). The diagramming software plots a polygon that represents the major anion (sulfate, chloride, nitrate, and bicarbonate) and major cation (calcium, magnesium, sodium, and potassium) concentrations as a point on individual axes.

Big Creek had one of the most dilute and strongly sodium-chloride types of ionic compositions of all the sites (fig. 13). All other sites exhibited a greater calcium-bicarbonate component than Big Creek. Boggy Branch had a similar ionic composition to Collins Creek, except for a much greater chloride and magnesium component. Long Branch and Crooked Creek had ionic compositions with the greatest overall concentrations and strongest calcium-bicarbonate component. The ionic composition of Hamilton Creek was similar to Crooked Creek, but Hamilton Creek had a greater sodium-chloride component and less magnesium. The ionic composition at the lake sites 

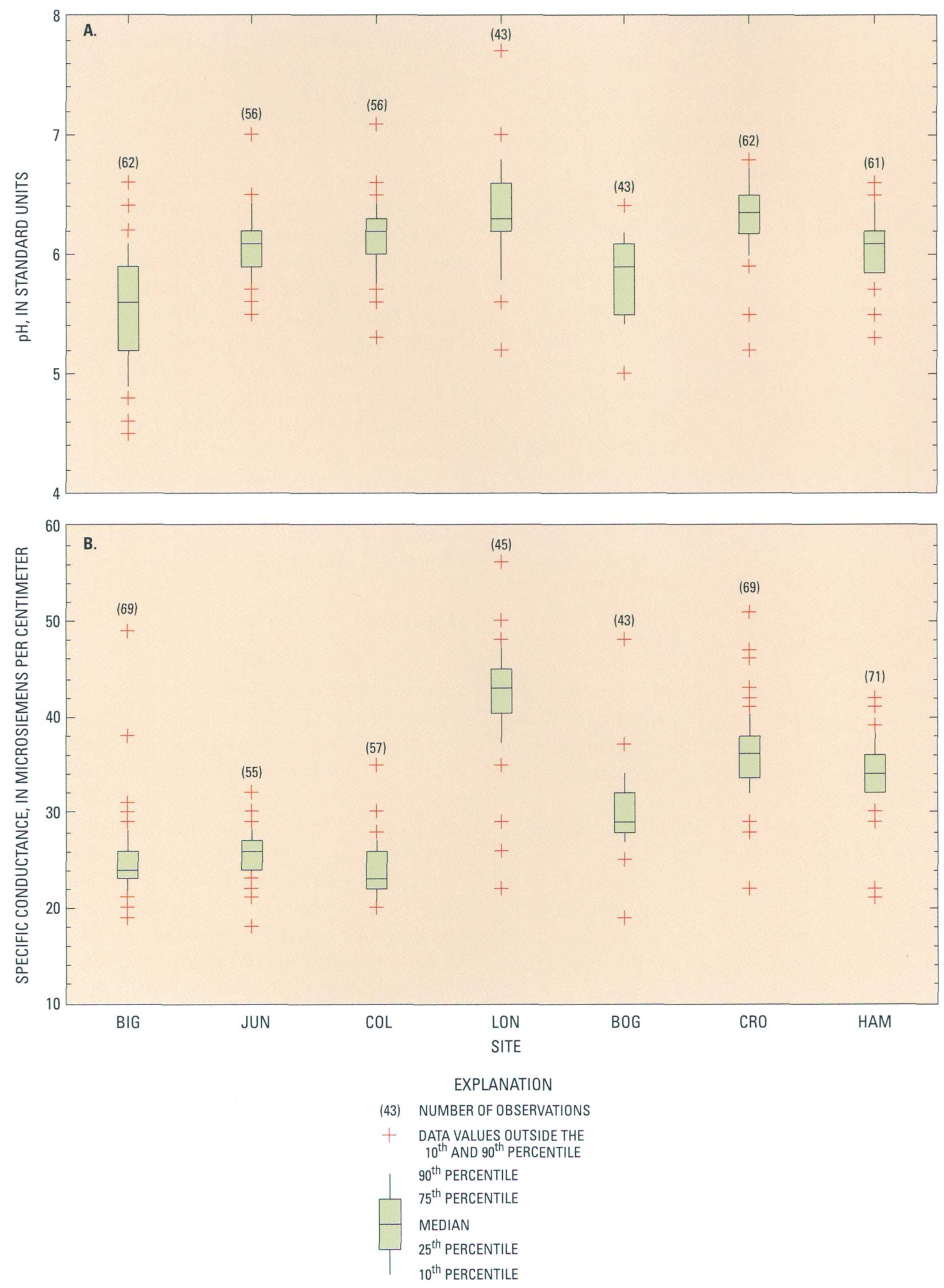

Figure 12. (A) pH and (B) specific conductance values at selected sites in the Converse Lake watershed, 1990-98. 

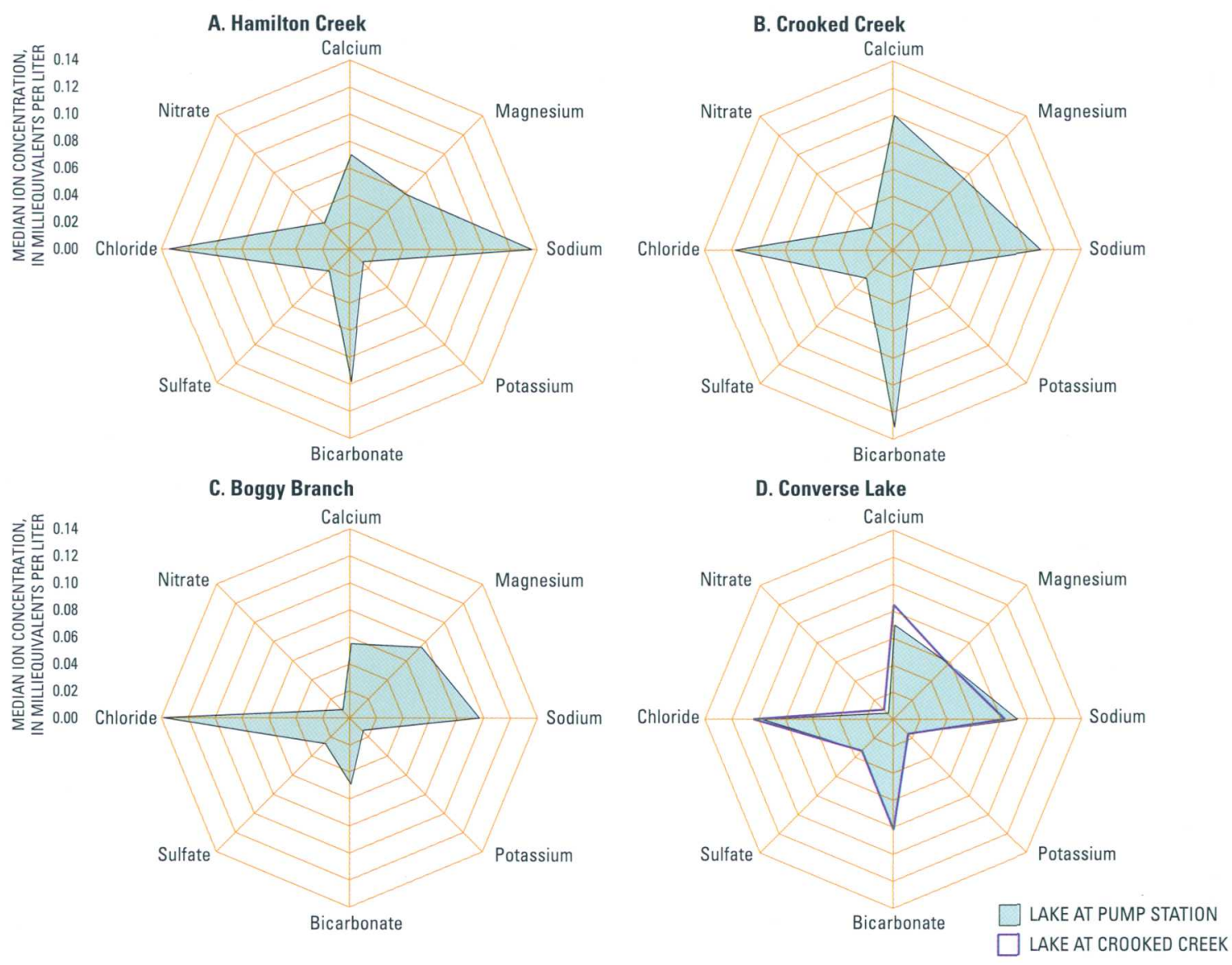

E. Long Branch

F. Juniper Creek

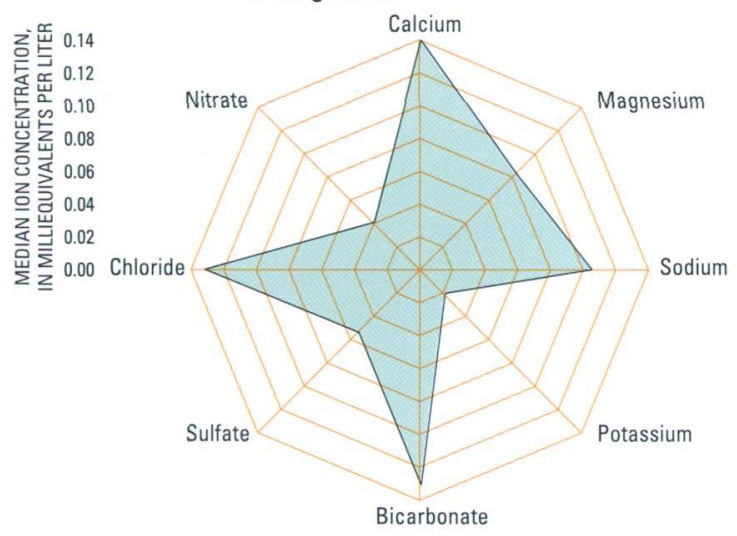

G. Collins Creek

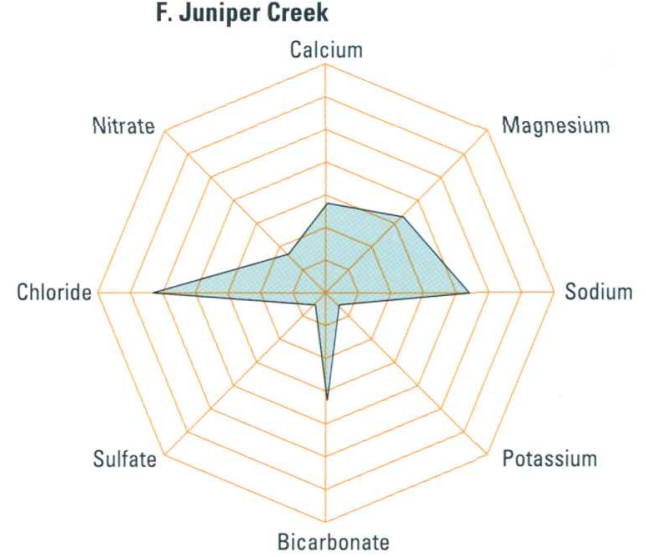

G. Collins Creek
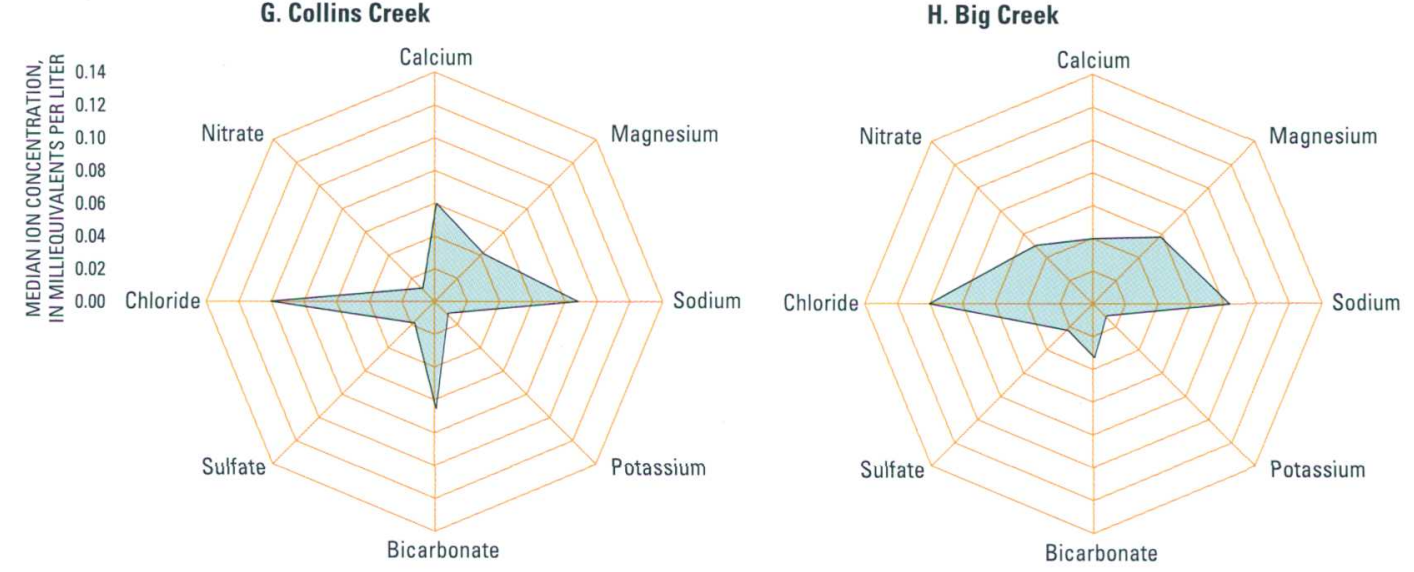

Figure 13. Radial plots of median ion concentrations, in milliequivalents per liter, at (A) Hamilton Creek, (B) Crooked Creek, (C) Boggy Branch, (D) Converse Lake, (E) Long Branch, (F) Juniper Creek, (G) Collins Creek, and (H) Big Creek in the Converse Lake watershed, 1990-98. 
appeared to be most like the composition of tributary waters in the central and southern parts of the watershed (Long Branch, Crooked Creek, and Hamilton Creek) and less similar to sites in the headwaters portion of the watershed. This similarity was especially evident in the proportion of cations (calcium, magnesium, sodium). The sulfate component of the overall ionic composition was minimal at all sites.

The chemistry of streamwater varies with flow conditions because of changes in the flow pathways in the watershed. During and immediately after a storm, the water in a stream is a mixture of surface runoff, shallow subsurface flow through the soil zone, and ground-water discharge. During base-flow conditions, streamwater is predominantly ground-water discharge. Ion concentrations during periods of base flow and high streamflow were plotted for Big Creek (site BIG, fig. 1), Hamilton Creek (site HAM), and Crooked Creek (site CRO) to identify changes in ionic composition with flow conditions (fig. 14). Big Creek exhibited effects of dilution during high streamflow conditions. The greatest nitrate and bicarbonate concentrations were during base flow at this site. Hamilton Creek exhibited slight dilution effects on silica and chloride, and an increase in the calciumbicarbonate component during high streamflow conditions. Crooked Creek had a similar response-decreased nitrate and increased calciumbicarbonate during high streamflow conditions as well as increased chloride.

In summary, no dramatic differences in ionic composition were observed among tributary and lake sites. The greatest difference was observed at Big Creek, which had proportionally lower calciumbicarbonate component than the other sites. Bicarbonate and nitrate fractions of the ionic composition in Big Creek were highest during baseflow periods, suggesting a ground-water source. Runoff and shallow soil-zone flow during high streamflow conditions contributed more dilute waters, causing a decrease in ionic concentration at Big Creek. Median ion concentrations of calcium and bicarbonate in Crooked Creek and Hamilton Creek depicted an increase in overall ion concentrations compared to Big Creek. The calcium-bicarbonate component of these increased ion concentrations occurred during high streamflow periods, suggesting ion introduction to the streamwater from runoff and soil-zone flushing. Higher concentrations of nitrate were evident during base flow in both Crooked and Hamilton Creeks, suggesting a ground-water source.

\section{pH and Alkalinity}

Hydrogen ions contribute acidity in water. Although hydrogen-ion $(\mathrm{H}+)$ concentrations in water can be measured in milligrams per liter, the extremely low hydrogen-ion concentrations in natural aquatic systems require measurement and reporting in logarithmic units. The term " $\mathrm{pH}$ " represents the negative base- $10 \log$ of the hydrogen-ion concentration or, specifically, the activity. The $\mathrm{pH}$ of natural systems generally ranges from 6 to about 9 , representing hydrogen-ion concentrations that range from $1 \times 10^{-6}$ to $1 \times 10^{-9}$ milligrams per liter (trace constituents). The ability or capacity of water to absorb hydrogen ions (neutralize acid) without a substantial change in $\mathrm{pH}$ is called the acid-neutralizing capacity (ANC) of the water. The ANC is a measure of the alkalinity of unfiltered water.

When the $\mathrm{pH}$ of aquatic systems falls below 4 or 5 , the diversity of the endemic aquatic species (plants and animals) can be severely restricted. Some influences related to human activities that can have an adverse effect on the $\mathrm{pH}$ of surface water are commercial and industrial discharges, urban runoff, acidic drainage from mines, and acid rain. The ADEM established a $\mathrm{pH}$ range of 6 to 8.5 to prevent aquaticspecies diversity restrictions in most natural water systems of the State (Alabama Department of Environmental Management, 2000). If, however, the $\mathrm{pH}$ range naturally falls below the criteria range, as in the case of waters draining resistant sandstone and granitic bedrocks or deeply weathered soils, the naturally occurring range is acceptable.

Although all sites in the Converse Lake watershed had $\mathrm{pH}$ levels that periodically fell below the ADEM lower level criterion of 6, only two streams had median $\mathrm{pH}$ levels below that level—sites BIG and BOG (fig. 1) had median pH values of 5.6 and 5.9, respectively. The remaining tributary and lake sites had median $\mathrm{pH}$ values that were within the criteria range (appendix 1; fig. 12). The highest median $\mathrm{pH}$ levels were recorded at tributary sites LON and CRO and at lake sites LCRO and LHAM, where the median $\mathrm{pH}$ levels were $6.3,6.4,6.2$, and 6.2 , respectively. Alkalinity and ANCs corresponded well with $\mathrm{pH}$ levels. Site BIG had the lowest median alkalinity ( $2 \mathrm{mg} / \mathrm{L}$ ), and sites $\mathrm{LON}$ and $\mathrm{CRO}$ had the highest 


\section{A. Big Creek - High flow}

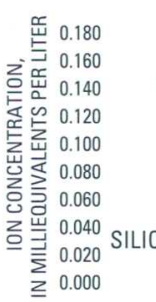

SILICA

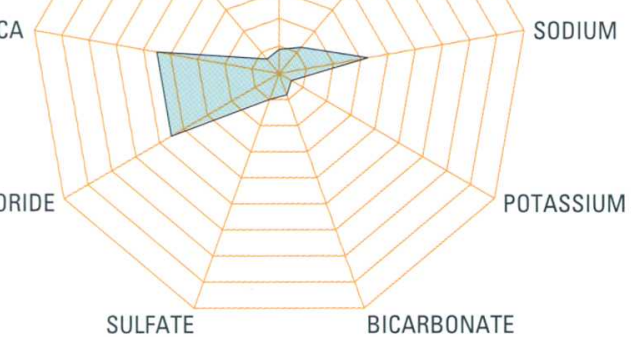

\section{Hamilton Creek - High flow}

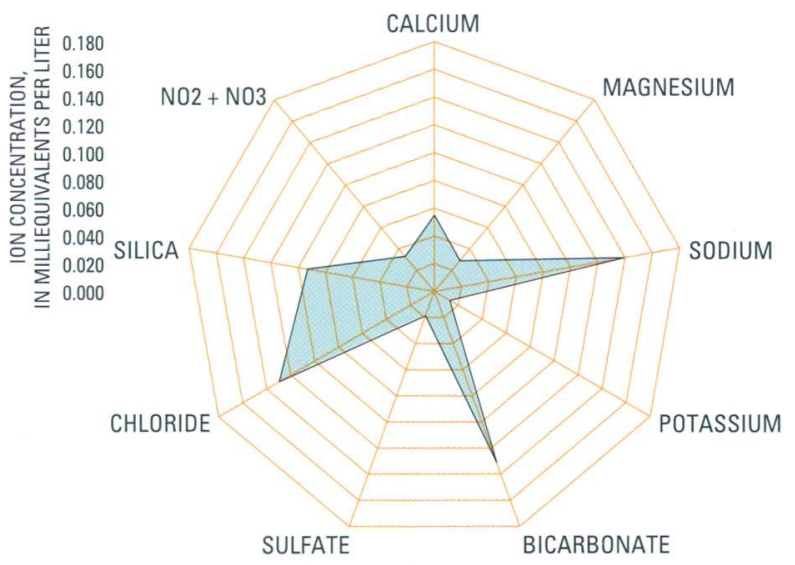

\section{E. Crooked Creek - High flow}

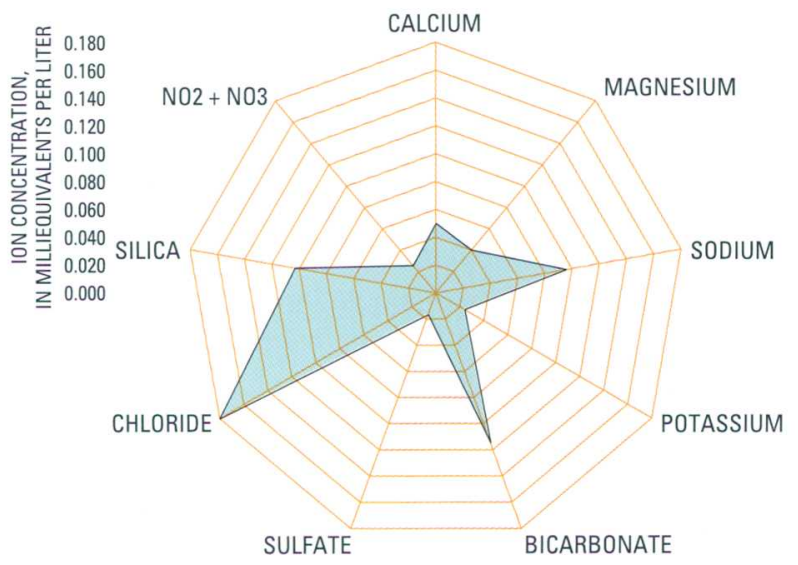

B. Big Creek - Baseflow

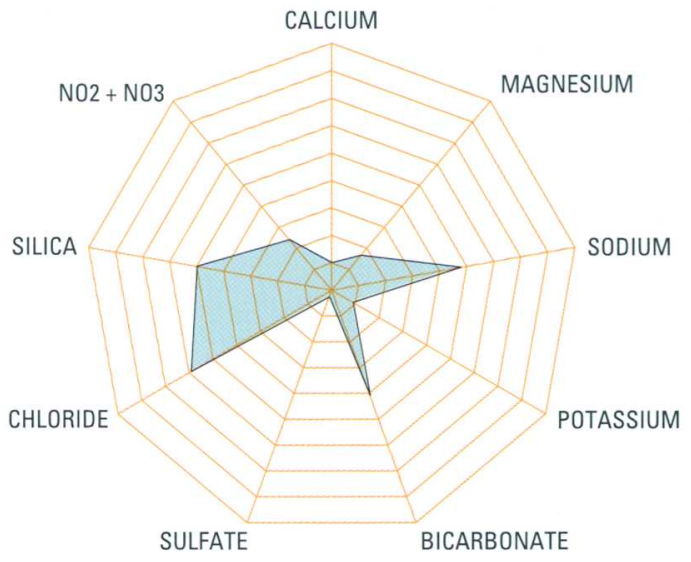

\section{Hamilton Creek - Baseflow}

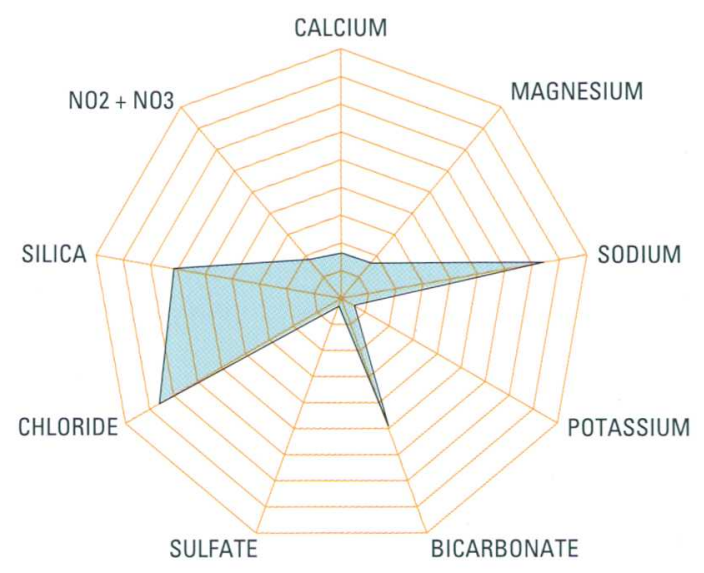

\section{F. Crooked Creek - Baseflow}

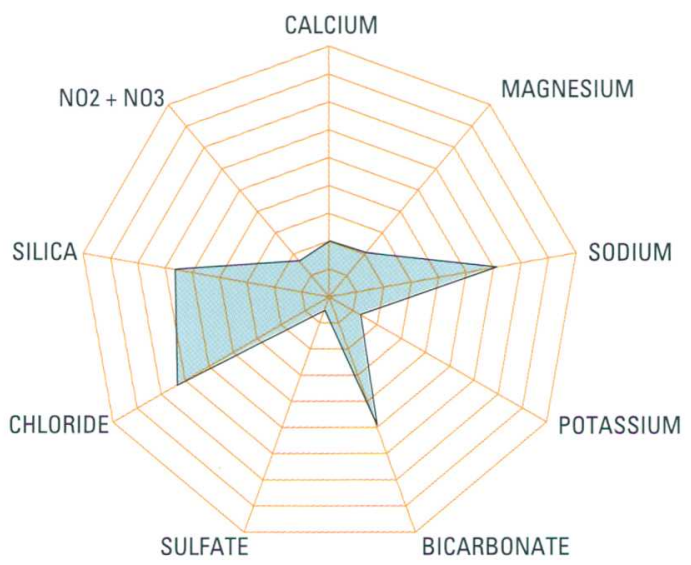

Figure 14. Radial plots of ionic concentrations, in milliequivalents per liter, at Big Creek, Hamilton Creek, and Crooked Creek during high streamflow conditions ( $A, C$, and $E$, respectively) and base-flow conditions ( $B, D$, and $F$, respectively) in the Converse Lake watershed, 1990-98. 
alkalinity ( $7 \mathrm{mg} / \mathrm{L})$. Median ANCs ranged from 3 (site BIG) to $8 \mathrm{mg} / \mathrm{L}$ (sites LON, CRO).

Percentages of land in each land-use category were computed for each subbasin in the 1992 MRLC coverage. The computed land-use percentages were correlated with median $\mathrm{pH}$ levels and ANCs for the tributary subbasins to determine if the more acidic $\mathrm{pH}$ levels were related to natural (forested) or anthropogenic (agricultural, residential) conditions in the watershed (table 5; fig. 15). Negative correlation coefficients indicate an inverse relation between land use and the median $\mathrm{pH}$ or ANC (when one increases,

Table 5. Spearman rho correlation coefficients for percentage of land use and median levels of pH, acid-neutralizing capacity, and specific conductance in the Converse Lake watershed

[MRLC, multi-resolution land characteristic. Coefficients that are statistically significant are bold $(p$-value $<0.05)]$

\begin{tabular}{lccc}
\hline \multicolumn{1}{c}{ MRLC land-use category } & PH & Water-quality constituent \\
\cline { 2 - 4 } & & $\begin{array}{c}\text { Acid-neutralizing } \\
\text { capacity }\end{array}$ & $\begin{array}{c}\text { Specific } \\
\text { conductance }\end{array}$ \\
\hline Evergreen forest & -0.1261 & -0.2245 & -0.7186 \\
Deciduous forest & -0.6126 & -0.7485 & -0.6786 \\
Mixed forest & -0.5225 & -0.5052 & -0.2143 \\
Transitional & -0.2883 & -0.6175 & -0.7143 \\
Row crops & 0.3964 & 0.2994 & 0 \\
Pasture and hay & 0.3434 & 0.6175 & 0.7143 \\
High-intensity residential & 0.6171 & 0.6602 & 0.3706 \\
Low-intensity residential & 0.6727 & 0.6797 & 0.3604 \\
Industrial/commercial/high-intensity residential & $\mathbf{0 . 8 8 2 9}$ & 0.1786 \\
Other grasses & 0.6171 & 0.6175 & -0.0371 \\
Wetlands & -0.1261 & 0.3690 & 0.2857 \\
\hline
\end{tabular}

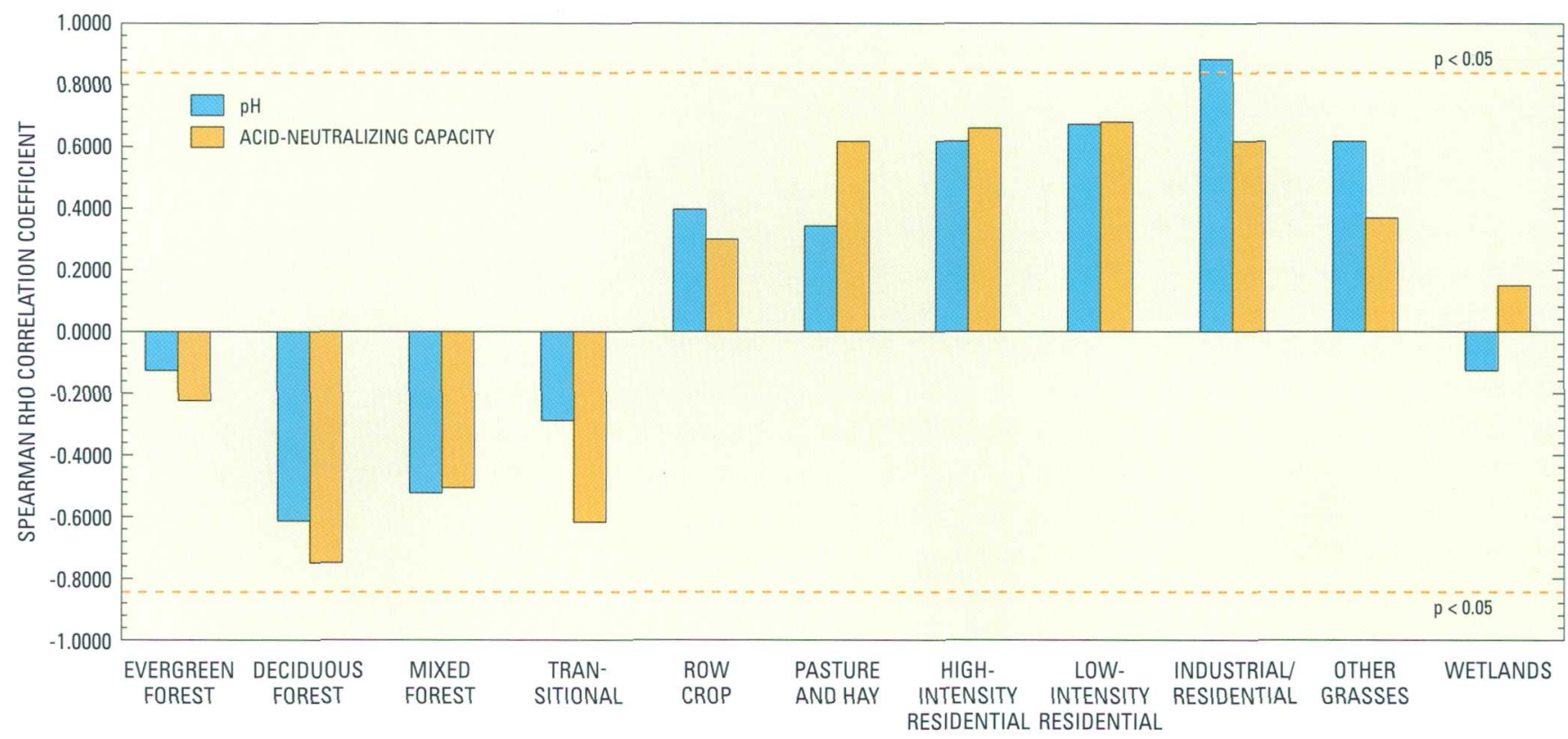

LAND-USE CATEGORY

Figure 15. Correlation between land-use category and median $\mathrm{pH}$ and acid-neutralizing capacity in tributary subbasins in the Converse Lake watershed. 
the other decreases); positive coefficients indicate direct relation (when one increases, the other also increases). No statistically significant relation was found among the agricultural land-use categories of row crops, pasture and hay, residential land use, other grasses (parks, fields), and forested land. The only significant relation $(p$-value $<0.05$ ) was between $\mathrm{pH}$ and commercial, industrial, and residential land (table 5). This relation was positive, suggesting the greater the amount of developed land, the less acidic the $\mathrm{pH}$.

In summary, Big Creek (site BIG) and Boggy Branch (site BOG) had median $\mathrm{pH}$ levels below the ADEM criterion of 6 and relatively low ANCs. Statistical correlations indicate that the greater the amount of commercial, industrial, and residential development (human influenced), the greater the tendency for the streamwater to have a more neutral median $\mathrm{pH}$ and a greater capacity to neutralize acid. This correlation, in conjunction with the environmental factors of resistant rock types and acidic soil in the watershed, provides a strong indication that low $\mathrm{pH}$ and low ANCs are of natural origin, not anthropogenic. In 1996, the ADEM 305(b) Water-Quality Report to Congress stated that Converse Lake, listed as Big Creek Lake, had $\mathrm{pH}$ values that fell below the criteria range of 6 to 8 , but also stated that the "Low $\mathrm{pH}$ values measured in Big Creek...are determined to be of natural origin and are considered unlikely to cause adverse impacts" (Alabama Department of Environmental Management, 1999).

\section{Trace Elements}

Iron and manganese are two trace elements that were monitored quarterly in the Converse Lake watershed. Water samples were analyzed for both total and dissolved species. These elements adversely affect the taste and odor of water; therefore, the ADEM has set secondary standards for acceptable levels of less than $300 \mu \mathrm{g} / \mathrm{L}$ for total iron and $50 \mu \mathrm{g} / \mathrm{L}$ for total manganese in drinking water, after filtration and treatment (Alabama Department of Environmental Management, 2000).

Converse Lake and its tributaries had median total iron concentrations that exceeded the National secondary drinking-water standard of $300 \mu \mathrm{g} / \mathrm{L}$ (fig. 16; appendix 1). However, this raw water would be filtered and treated prior to distribution in the drinking-water system, resulting in iron concentrations below these limits. Median dissolved iron concentrations generally were one-half to one-third of the total iron value. The highest median concentrations of total iron were 940 and $725 \mu \mathrm{g} / \mathrm{L}$ in Boggy Branch (site BOG) and Crooked Creek (site CRO), respectively; the lowest median concentrations of 315 and $320 \mu \mathrm{g} / \mathrm{L}$ were in the lake sites LCRO and LHAM, respectively. Boggy Branch was the only site with a median total manganese concentration $(79 \mu \mathrm{g} / \mathrm{L})$ that exceeded the secondary standard of $50 \mu \mathrm{g} / \mathrm{L}$. Collins Creek (site COL) and the lake site at the pump station (site LHAM) had the lowest median concentrations of total manganese (23 and $20 \mu \mathrm{g} / \mathrm{L}$, respectively).

\section{NUTRIENT LOADING AND TROPHIC RESPONSE}

The amount of biologically available nutrients, mainly phosphorus and nitrogen compounds, contributes to the trophic state of a water body. Nutrient enrichment accelerates the process of eutrophication, which results in excessive growth of algae (algal blooms) and other aquatic plants. Nuisance algal production causes a variety of associated water-quality problems, including increased biochemical oxygen demand, extreme vertical changes in dissolved-oxygen concentrations (from oversaturated to depleted), high turbidity, unpleasant odors and tastes, and blockages of water-purification systems at treatment facilities. Globally, the process of eutrophication has increased rapidly as a result of human activities, including runoff (nonpoint) from agricultural areas and the discharge of industrial wastes and treated municipal sewage, that contribute excess nutrients to streams, rivers, lakes, and estuaries.

The relation between the annual input of nutrients and the in-lake phosphorus and nitrogen concentrations is central to understanding and managing eutrophication problems. This complex relation involves the interaction of physical and chemical processes and biological responses, requiring a distinction between trophic potential and trophic response. The trophic potential of a reservoir is the carrying or assimilating capacity of the ecosystem, and is a function of physical and chemical properties, such as nutrient concentrations, light penetration, climate, and hydraulic regime. The trophic response of a reservoir refers to the amount, type, and rate of biomass production and the water-quality variations that occur as a result of nutrient inputs. In order to predict or monitor the trophic response of a reservoir and its 


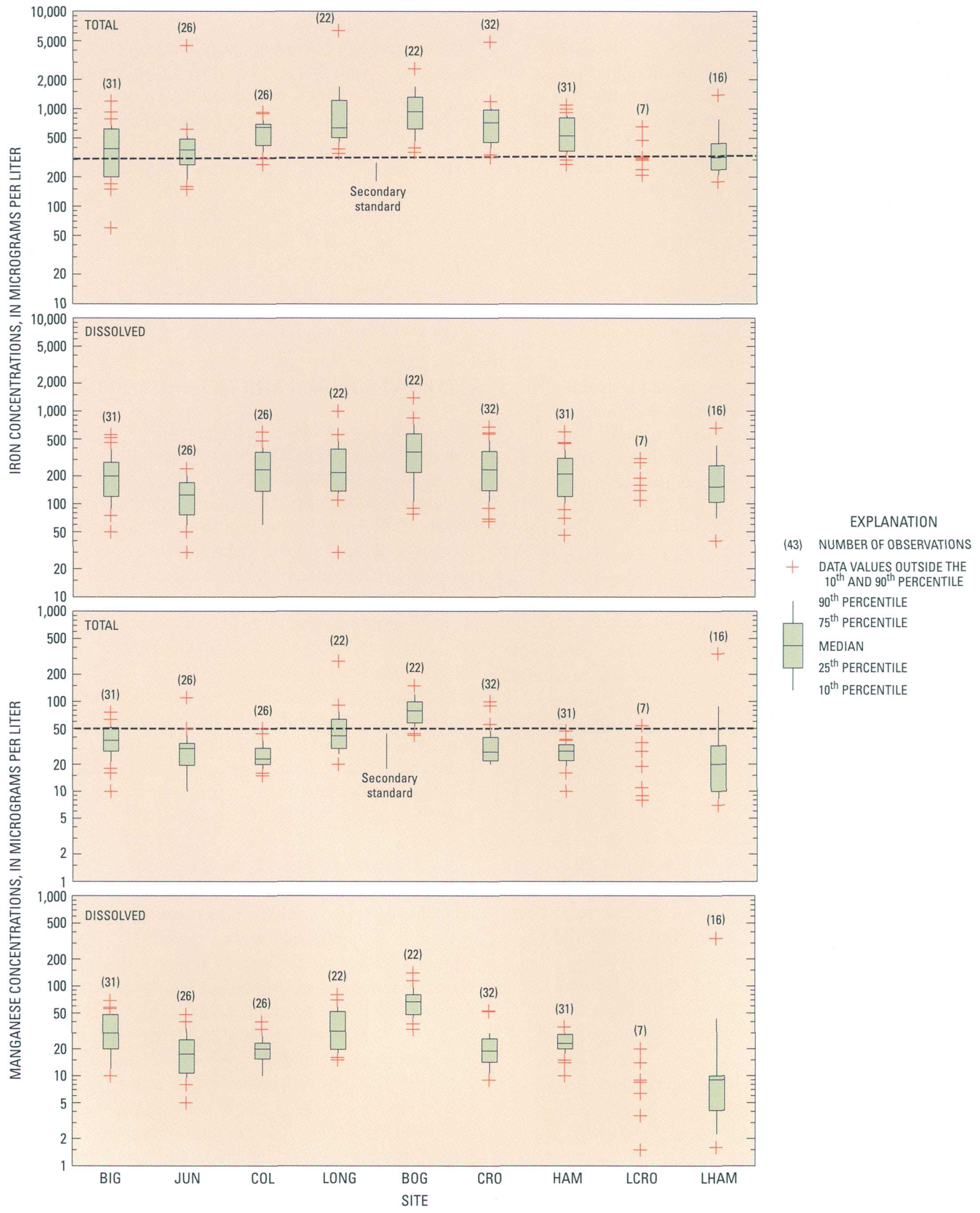

Figure 16. Boxplots of total and dissolved iron and manganese concentrations at selected sites in the Converse Lake watershed, 1990-98 
associated water-quality changes, easily measured trophic potential factors (nutrient concentration, inflow) must be correlated with the trophic response variables (transparency, chlorophyll, hypolimnetic dissolved oxygen).

An index that estimates the trophic state can be computed from empirically derived equations determined from trophic response and trophic potential data from different lake systems. One of the most commonly used indices is Carlson's Trophic State Index (TSI), which is based on transparency, phosphorus concentrations, and chlorophyll $a$ levels in a lake during the summer months (Carlson, 1977). Chlorophyll $a$ is a pigment found in algae, and is considered an estimate of the amount of algae present in the water. Greater algal production generally is related to enrichment of lake water with plant nutrients, such as nitrogen and phosphorus. A TSI value of less than 40 is indicative of oligotrophic or nutrient-poor conditions (table 6). A TSI value of 40 to 50 is indicative of mesotrophic or nutrient-balanced conditions. A TSI value of 50 to 70 is indicative of eutrophic or nutrient-enriched conditions. Eutrophic conditions in a lake can lead to a variety of waterquality problems, including unpleasant tastes and odors, depletion of dissolved oxygen (anoxia), and nuisance algal blooms. A TSI value above 70 indicates hypertrophic or extremely nutrient-rich conditions. In hypertrophic conditions, eutrophic water-quality problems become more pronounced, algal blooms are more common, and fish communities become dominated by bottom dwellers.

The results of ADEM's Reservoir Water Quality Monitoring Program were reported in the Alabama 305(b) Water-Quality Reports to Congress (Alabama Department of Environmental Management, 1996, 1999). More than two-thirds of the lakes that were assessed in Alabama were classified as eutrophic. In

Table 6. Potential changes in lake characteristics related to trophic state (modified from Rast and Lee, 1978) $[<$, less than; $>$, greater than]

\begin{tabular}{|c|c|c|}
\hline Trophic state index ${ }^{a}$ & $\begin{array}{l}\text { Trophic state } \\
\text { classification }\end{array}$ & Potential changes in lake characteristics \\
\hline$<30$ & Oligotrophic & $\begin{array}{l}\text { Clear water, oxygen in hypolimnion (deepest part of lake) year round. Sparse } \\
\text { macrophyte (rooted aquatic plants) growth. Many algal species but low } \\
\text { production. }\end{array}$ \\
\hline $30-40$ & & Hypolimnion of shallower lakes becomes anoxic (lacking in oxygen). \\
\hline $40-50$ & Mesotrophic & $\begin{array}{l}\text { Water moderately clear but increasing probability of anoxic hypolimnion } \\
\text { during summer. Increased iron and manganese levels evident during the } \\
\text { summer months. }\end{array}$ \\
\hline $50-60$ & Eutrophic & $\begin{array}{l}\text { Anoxic hypolimnion. Greater potential for iron and manganese, taste and } \\
\text { odor problems. Increase in macrophyte growth. Algal species become less } \\
\text { diverse. Surface-dwelling warm-water fish dominate, such as perch and } \\
\text { bass, but bottom-dwellers, such as catfish and carp, are present. }\end{array}$ \\
\hline $60-70$ & & $\begin{array}{l}\text { Dominant algal groups change from greens and diatoms to blue-greens; algal } \\
\text { scums and macrophyte problems. }\end{array}$ \\
\hline$>70$ & Hypertrophic & $\begin{array}{l}\text { Light limited due to lack of transparency and high turbidity. Dense algae and } \\
\text { macrophyte growth. Bottom-dwelling fish, such as catfish and carp, domi- } \\
\text { nate. }\end{array}$ \\
\hline
\end{tabular}

"Carlson, 1977. 
the 305(b) report, concern was expressed over the trophic state of Converse Lake, listed by its former name, Big Creek Lake. Although Converse Lake was considered stable and supportive of both its designated uses (aquatic life and water supply), a noticeable increase in the trophic state condition of Converse Lake was reported.

Defining the exact concentration of nitrogen or phosphorus that causes nutrient enrichment and an associated trophic response in a water body is difficult. The USEPA developed guidelines in 1975 for nutrient, chlorophyll $a$, and hypolimnetic dissolved-oxygen levels that can be used for trophic state determination as part of the National Eutrophication Survey (Gakstatter and others, 1975; table 7). The guidelines were developed from data collected at 96 lakes in the United States.

As part of a global effort by the Organization for Economic Cooperation and Development (OECD) project, data were collected and the relation between nutrient load and a lake's trophic response was quantified. The project consisted of four regional studies-Alpine, Nordic, Reservoir, and North American. The OECD index was developed based on the average value for each parameter for each trophic state. The results were summarized using a statistical approach to quantify the ranges of several parameters within the three trophic state conditions (Vollenweider and Kerekes, 1980; table 8). The results of the OECD study emphasized that lakes can have similar nutrient

Table 7. National Eutrophication Survey guidelines for trophic state determination (modified from Gakstatter and others, 1975) [mg/L, milligram per liter; <, less than; >, greater than; $\mu \mathrm{g} / \mathrm{L}$, microgram per liter; $\mathrm{m}$, meter]

\begin{tabular}{lccc}
\hline \multicolumn{1}{c}{ Parameter } & Oligotrophic & Mesotrophic & Eutrophic \\
\hline Total phosphorus $(\mathrm{mg} / \mathrm{L})$ & $<0.01$ & $0.01-0.02$ & $>0.02$ \\
Chlorophyll $a(\mu \mathrm{g} / \mathrm{L})$ & $<4$ & $4-10$ & $>10$ \\
Secchi depth $(\mathrm{m})$ & $>3.7$ & $2.0-3.7$ & $<2.0$ \\
$\begin{array}{l}\text { Hypolimnetic dissolved oxygen } \\
\text { (percent saturation) }\end{array}$ & $>80$ & $10-80$ & $<10$ \\
\hline
\end{tabular}

Table 8. Organization for Economic Cooperation and Development indices for trophic state determination based on scientific opinion (from Vollenweider and Kerekes, 1980)

[mg/L, milligram per liter; $\mu \mathrm{g} / \mathrm{L}$, microgram per liter; $\mathrm{m}$, meter]

\begin{tabular}{|c|c|c|c|c|c|c|}
\hline \multirow{2}{*}{ Parameter } & \multicolumn{2}{|c|}{ Oligotrophic } & \multicolumn{2}{|c|}{ Mesotrophic } & \multicolumn{2}{|c|}{ Eutrophic } \\
\hline & $\begin{array}{c}\text { Geometric } \\
\text { mean }\end{array}$ & Range & $\begin{array}{c}\text { Geometric } \\
\text { mean }\end{array}$ & Range & $\begin{array}{c}\text { Geometric } \\
\text { mean }\end{array}$ & Range \\
\hline $\begin{array}{l}\text { Total phosphorus } \\
\qquad(\mathrm{mg} / \mathrm{L})\end{array}$ & 0.008 & $0.003-0.018$ & 0.027 & $0.011-0.096$ & 0.084 & $0.016-0.39$ \\
\hline $\begin{array}{l}\text { Total nitrogen } \\
\quad(\mathrm{mg} / \mathrm{L})\end{array}$ & 0.66 & $0.31-1.60$ & 0.75 & $0.36-1.40$ & 1.9 & $0.39-6.1$ \\
\hline $\begin{array}{l}\text { Chlorophyll } a \\
(\mu \mathrm{g} / \mathrm{L})\end{array}$ & 1.7 & $0.3-4.5$ & 4.7 & $3-11$ & 14 & $2.7-78$ \\
\hline $\begin{array}{l}\text { Peak chlorophyll } a \\
\quad(\mu \mathrm{g} / \mathrm{L})\end{array}$ & $4.2^{\mathrm{a}}$ & $1.3-11$ & $16^{\mathrm{a}}$ & $5-50$ & $43^{a}$ & $10-280$ \\
\hline $\begin{array}{l}\text { Secchi depth } \\
\text { (m) }\end{array}$ & 9.9 & $5.4-28$ & 4.2 & $1.5-8.1$ & 2.4 & $0.8-7.0$ \\
\hline
\end{tabular}

\footnotetext{
${ }^{\mathrm{a}}$ This value is an arithmetic mean, not a geometric mean.
} 
and chlorophyll $a$ concentrations, yet be placed in different trophic states.

Nitrogen occurs in natural waters in several different forms-dissolved molecular nitrogen $\left(\mathrm{N}_{2}\right)$, organic compounds (amino acids, amines, proteins, and refractory humic compounds of low nitrogen content), ammonia $\left(\mathrm{NH}_{4}{ }^{+}\right)$, nitrite $\left(\mathrm{NO}_{2}{ }^{-}\right)$, and nitrate $\left(\mathrm{NO}_{3}{ }^{+}\right)$. Total Kjeldahl nitrogen (TKN) is the sum of total organic nitrogen and total ammonia species. For this report, total inorganic nitrogen (TIN) is the sum of total nitrate and nitrite species.

Nitrogen from specific sources enters the hydrologic cycle in characteristic forms. Sources of TKN include the decay of organic material, such as vegetation (algae), animal wastes, and urban sewage. Large amounts of ammonia and organic nitrogen are applied to cropland as fertilizers, but are relatively immobile in soils because of adsorption to soil surfaces. Under oxygen-rich conditions, however, TKN can be converted to the extremely mobile forms of nitrate and nitrite, which readily enter the groundand surface-water systems.

A biologically catalyzed cycle converts one form of nitrogen into another. Bacteria and blue-green algae can transform atmospheric nitrogen into ammonia by the process called nitrogen fixation. Other bacteria catalyze the oxidation of ammonium to nitrite, then to nitrate by the process called nitrification; this process occurs rapidly in the oxygen-rich environment of most streams. Ammonia is the preferred form for algal uptake, followed by nitrate and nitrite, then dissolved molecular nitrogen (Wetzel, 1983). These nitrogen species can be taken up by organisms and incorporated into organic materials, which in turn decay and release nitrogen in the form of ammonia.

Like nitrogen, phosphorus exists in the aquatic environment in several forms, including inorganic and organic species. The most important form of inorganic phosphorus is orthophosphate $\left(\mathrm{PO}_{4}{ }^{-3}\right)$ which is the form of phosphorus that is available for use by biota (Wetzel, 1983). Approximately 30 to 60 percent of the phosphorus in many natural waters is organically bound (Snoeyink and Jenkins, 1980). Phosphorus tends to adsorb strongly to particles in soils, suspended solids, and bed sediments.

Potential sources of nutrients in the Converse Lake watershed are from nonpoint contributions from atmospheric deposition, fertilizer applications on agricultural and residential land, livestock wastes, residential runoff, failing septic systems, contaminated ground water, and natural sources. No known point sources are located in the Converse Lake watershed.

\section{Nutrient Analysis Methods and Approach}

Trends in concentrations of total nitrogen and phosphorus, total inorganic nitrogen, total Kjeldahl nitrogen, and total orthophosphate (as phosphorus) were determined for one lake and seven tributary sites from water-quality data collected during the period October 1990 to June 1998. Trend analyses were performed on actual concentrations and concentrations adjusted for streamflow by using a statistical technique known as Locally Weighted Regression and Smoothing of Scatter Plots (LOWESS). This technique produces a continuous curvilinear line through the data points. Flow adjustment of concentration data eliminates variations in concentrations related to streamflow, allowing for a more accurate detection of trends in water quality over time. The actual concentrations and the residuals from the LOWESS relation were subjected to a trend analysis known as a seasonal Kendall trends test (Hirsch and others, 1982; Helsel and Hirsch, 1992), which accounts for seasonal variations in the constituent concentrations.

Annual and monthly in-stream loads of nitrogen, phosphorus, and silica were calculated as the product of the daily streamflow and estimated daily concentrations for the three continuous-record surfacewater stations (Big Creek, Crooked Creek, and Hamilton Creek). Daily constituent concentration data were estimated by using Cohn's estimator model (Cohn and others, 1989; Gilroy and others, 1990; Cohn and others, 1992). This model includes a seven-constituent log-linear regression analysis of constituent concentrations against measured environmental variables.

$$
\begin{gathered}
\ln (C)=\beta_{0}+\beta_{1}\left\langle\ln \left[Q-Q^{\prime}\right]\right\rangle+\beta_{2}\left(\ln \left[Q-Q^{\prime}\right]\right)^{2} \\
+\beta_{3}\left[t-t^{\prime}\right]+\beta_{4}\left[t-t^{\prime}\right]^{2}+\beta_{5} \sin [2 \pi t] \\
+\beta_{6} \cos [2 \pi t]+\varepsilon
\end{gathered}
$$

where

$$
\begin{aligned}
\ln = & \text { natural logarithm function }, \\
C= & \text { concentration (in milligrams per liter) }, \\
Q= & \text { instantaneous discharge (in cubic feet per } \\
& \text { second) }, \\
t= & \text { time (in decimal years) },
\end{aligned}
$$




$$
\begin{aligned}
\sin = & \text { sine function, } \\
\cos = & \text { cosine function, } \\
\pi= & 3.14169, \\
\beta_{0} \text { to } \beta_{6}= & \text { coefficients of the regression model, } \\
\varepsilon= & \text { model errors, } \\
Q^{\prime}= & \text { centering variable defined so that } \beta_{1} \text { and } \beta_{2} \\
t^{\prime}= & \text { are statistically independent, and } \\
& \text { are statistically independent. }
\end{aligned}
$$

The regression analysis assumes that model errors $(\varepsilon)$ are independent and normally distributed, with zero mean and variance. The Minimum Variance Unbiased Estimator (MVUE) (Bradu and Mundlak, 1970) was included in the model to correct for the retransformation bias associated with log-linear regression models; the model also employs the Adjusted Maximum Likelihood Estimator (Cohn, 1988), which statistically adjusts for censored data and multiple reporting limits.

Equation 1 results in an estimate of the daily logarithmic constituent concentrations. The estimated daily constituent concentrations are then multiplied by the daily mean discharge to produce a daily mean load by using the following equation.

$$
\ln \left[L_{i}\right]=Q_{i} \times \ln \left[C_{i}\right] \times K,
$$

where

$\ln =$ the natural logarithm function,

$L_{i}=$ the daily mean load (in kilograms per day),

$i=$ any interval,

$Q_{i}=$ the daily mean discharge for that interval (in cubic feet per second),

$C_{i}=$ the mean concentration (in milligrams per liter), and

$K=2.447$, the correction factor for unit conversion.

Yields allow easy comparison among sites with differing drainage areas; yields were computed by dividing the estimated load by the drainage area of the subbasin.

\section{Results of Nutrient Analysis}

Annual and monthly nutrient loads were estimated at three tributary sites in the Converse Lake watershed by using regression techniques. Nutrient yields also were computed from the estimated loads to allow for comparison among sites. Nutrient concentrations from October 1990 to June 1998 were analyzed to determine if any trends existed at the seven tributary sites and one lake site (site LHAM). The trophic response of the lake to the nutrient loads also was evaluated.

\section{Nutrient Loads}

Regression analyses were performed on seven species of nutrients-total inorganic nitrogen, ammonia, organic nitrogen, total Kjeldahl nitrogen, total nitrogen, total phosphorus, and orthophosphate. Regression summaries for the input data of nutrient concentrations are listed in table 9. Data used as input to the logarithmic-linear regression model are statistically summarized in appendix 1 . Regression summaries include the variance $(s)$ and the coefficient of determination $\left(\mathrm{r}^{2}\right)$ for each constituent, the model variables, and the coefficients used to determine the concentration for each variable.

The $T$ value is the measure of the significance of the coefficients in the seven-parameter model. A model value with an absolute $T$ value greater than 2 is considered to be significant, with the exception of the sine and cosine variables ( $\beta_{5}$ and $\beta_{6}$, respectively). Because these variables together indicate seasonality, if either variable is significant, the other is considered significant. A significant variable indicates a relation to constituent concentration. For example, the statistical significance of variable $\beta_{1}$ indicates that streamflow, independent of other influences, is a good predictor of concentration. Temporal trends in nutrient concentrations are interpreted based on the statistical significance of $\beta_{3}$. Significant coefficients based on $\mathrm{T}$ values (not listed) are shown in bold in table 9 .

The $\mathrm{r}^{2}$, or coefficient of determination, is the percentage of the variation explained by the regression equation. For example, an $r^{2}$ of 74 indicates that approximately 74 percent of the variation in the actual data is explained by the equation. Because the data sets used to develop these equations cover only 1 year for Long and Boggy Branch and 2 years for Juniper and Collins Creek, the equations have relatively higher variance, as represented by the $s$ values. Errors associated with predicted concentrations decrease as the number of samples collected increases.

The relative influence of nonpoint sources and point sources on water quality in the selected tributary subbasins can be examined by comparing the statistical significance of the streamflow regression coefficient, 
Table 9. Regression summary for the seven-parameter, log-linear model used to estimate nutrient concentrations at selected sites in the Converse Lake watershed

[s, standard deviation of the residuals from ordinary least squares fit; $r^{2}$, coefficient of determination; $n$, number of observations used to fit the model; $\beta_{0}$, constant; $\beta_{1}$, coefficient of natural logarithm of streamflow; $\beta_{2}$, coefficient of natural logarithm of streamflow, squared; $\beta_{3}$, coefficient of time; $\beta_{4}$, coefficient of time, squared; $\beta_{5}$, coefficient of sine (time); $\beta_{6}$, coefficient of cosine (time); bold indicates coefficients with an absolute T value greater than 2 , which indicates significance; - , no data]

Big Creek at County Road 63 near Wilmer, 02479945 (site BIG)

\begin{tabular}{|c|c|c|c|c|c|c|c|c|c|}
\hline $\mathbf{s}$ & $r^{2}$ & $\mathbf{n}$ & $\beta_{0}$ & $\beta_{1}$ & $\beta_{2}$ & $\beta_{3}$ & $\beta_{4}$ & $\beta_{5}$ & $\beta_{6}$ \\
\hline \multicolumn{10}{|c|}{ Total nitrogen } \\
\hline 0.17462 & 0.952 & 36 & 4.5788 & 0.9617 & 0.0654 & -0.0381 & 0.0128 & -0.1205 & -0.0886 \\
\hline \multicolumn{10}{|c|}{ Total Kjeldahl nitrogen } \\
\hline 0.25928 & 0.944 & 45 & 3.8143 & 1.3822 & 0.0548 & -0.0789 & -0.0059 & -0.1280 & -0.2428 \\
\hline \multicolumn{10}{|c|}{ Total organic nitrogen } \\
\hline 0.45647 & 0.619 & 45 & 1.3867 & 0.5916 & -0.2125 & -0.0826 & -0.0036 & 0.1227 & -0.0300 \\
\hline \multicolumn{10}{|c|}{ Total ammonia nitrogen } \\
\hline 0.23379 & 0.954 & 35 & 3.8086 & 1.4066 & 0.0416 & -0.0087 & 0.0132 & -0.2075 & -0.2683 \\
\hline \multicolumn{10}{|c|}{ Total inorganic nitrogen } \\
\hline 0.65873 & 0.370 & 46 & 3.4199 & 0.3984 & 0.0886 & -0.1155 & 0.0256 & 0.0654 & 0.0854 \\
\hline \multicolumn{10}{|c|}{ Total phosphorus } \\
\hline 0.79814 & 0.564 & 47 & 0.8598 & 1.2094 & - & 0.0384 & - & -0.1885 & 0.0852 \\
\hline \multicolumn{10}{|c|}{ Total orthophosphorus } \\
\hline 0.00000 & 1.000 & 46 & 0.3698 & 1.0000 & - & 0.0000 & - & 0.0000 & 0.0000 \\
\hline
\end{tabular}

Juniper Creek at Glenwood Road near Fairview, 02479948 (site JUN)

\begin{tabular}{|c|c|c|c|c|c|c|c|c|c|}
\hline $\mathbf{s}$ & $r^{2}$ & n & $\beta_{0}$ & $\beta_{1}$ & $\beta_{2}$ & $\beta_{3}$ & $\beta_{4}$ & $\beta_{5}$ & $\beta_{6}$ \\
\hline \multicolumn{10}{|c|}{ Total nitrogen } \\
\hline 0.21120 & 0.914 & 15 & 3.6186 & 1.2182 & -0.2516 & 0.1828 & 0.3444 & -0.0197 & -0.0604 \\
\hline \multicolumn{10}{|c|}{ Total Kjeldahl nitrogen } \\
\hline 0.48771 & 0.780 & 22 & 2.5123 & 1.9145 & -0.3111 & 0.0472 & 0.5640 & -0.0030 & -0.1662 \\
\hline \multicolumn{10}{|c|}{ Total organic nitrogen } \\
\hline 0.50111 & 0.736 & 21 & -0.2969 & 1.8449 & -0.3239 & 0.2984 & 0.4448 & -0.1841 & 0.2092 \\
\hline \multicolumn{10}{|c|}{ Total ammonia nitrogen } \\
\hline 0.35746 & 0.902 & 14 & 2.6389 & 1.7567 & -0.9557 & 0.0969 & 1.7190 & -0.2388 & -0.1634 \\
\hline \multicolumn{10}{|c|}{ Total inorganic nitrogen } \\
\hline 0.14268 & 0.865 & 22 & 2.9863 & 0.5089 & -0.0527 & 0.1211 & -0.3242 & 0.0556 & 0.0087 \\
\hline \multicolumn{10}{|c|}{ Total phosphorus } \\
\hline 1.6806 & 0.559 & 22 & -0.0208 & 3.0008 & - & 1.1154 & - & -0.5257 & 0.5632 \\
\hline \multicolumn{10}{|c|}{ Total orthophosphorus } \\
\hline - & - & - & - & - & - & - & - & - & - \\
\hline
\end{tabular}

Collins Creek at Glenwood Road near Fairview, 02479950 (site COL)

\begin{tabular}{|c|c|c|c|c|c|c|c|c|c|}
\hline $\mathbf{s}$ & $r^{2}$ & n & $\beta_{0}$ & $\beta_{1}$ & $\beta_{2}$ & $\beta_{3}$ & $\beta_{4}$ & $\beta_{5}$ & $\beta_{6}$ \\
\hline \multicolumn{10}{|c|}{ Total nitrogen } \\
\hline 0.18147 & 0.947 & 15 & 3.0989 & 1.2212 & 0.2776 & -0.0434 & -0.1851 & -0.0271 & -0.0545 \\
\hline \multicolumn{10}{|c|}{ Total Kjeldahl nitrogen } \\
\hline 0.27668 & 0.889 & 22 & 2.5112 & 1.5333 & 0.4112 & -0.0011 & -0.1261 & -0.0030 & -0.1979 \\
\hline \multicolumn{10}{|c|}{ Total organic nitrogen } \\
\hline 0.35532 & 0.842 & 22 & -0.1938 & 1.8439 & -0.7371 & 0.2604 & 0.3858 & -0.2329 & -0.3952 \\
\hline \multicolumn{10}{|c|}{ Total ammonia nitrogen } \\
\hline 0.22210 & 0.945 & 15 & 2.5664 & 1.3756 & 0.5555 & -0.0960 & -0.2207 & 0.0444 & -0.1052 \\
\hline \multicolumn{10}{|c|}{ Total inorganic nitrogen } \\
\hline 0.17477 & 0.839 & 23 & 1.9871 & 0.8225 & -0.3740 & 0.0536 & -0.1092 & -0.0998 & 0.0874 \\
\hline \multicolumn{10}{|c|}{ Total phosphorus } \\
\hline 0.69307 & 0.504 & 24 & -0.3192 & 1.5228 & 0.3541 & 0.4934 & -0.0690 & 0.0052 & 0.2477 \\
\hline \multicolumn{10}{|c|}{ Total orthophosphorus } \\
\hline 一 & - & - & - & - & - & - & - & - & - \\
\hline
\end{tabular}


Table 9. Regression summary for the seven-parameter, log-linear model used to estimate nutrient concentrations at selected sites in the Converse Lake watershed-Continued

[s, standard deviation of the residuals from ordinary least squares $\mathrm{fit} ; \mathrm{r}^{2}$, coefficient of determination; $\mathrm{n}$, number of observations used to fit the model; $\beta_{0}$, constant; $\beta_{1}$, coefficient of natural logarithm of streamflow; $\beta_{2}$, coefficient of natural logarithm of streamflow, squared; $\beta_{3}$, coefficient of time; $\beta_{4}$, coefficient of time, squared; $\beta_{5}$, coefficient of sine (time); $\beta_{6}$, coefficient of cosine (time); bold indicates coefficients with an absolute T value greater than 2 , which indicates significance; - , no data]

Long Branch near Wilmer, 02479955 (site LON)

\begin{tabular}{|c|c|c|c|c|c|c|c|c|c|}
\hline $\mathbf{s}$ & $r^{2}$ & n & $\beta_{0}$ & $\beta_{1}$ & $\beta_{2}$ & $\beta_{3}$ & $\beta_{4}$ & $\beta_{5}$ & $\beta_{6}$ \\
\hline \multicolumn{10}{|c|}{ Total nitrogen } \\
\hline 0.32975 & 0.915 & 10 & 4.0791 & 1.1099 & -0.0016 & 0.8848 & -16.9089 & -1.4540 & 0.2904 \\
\hline \multicolumn{10}{|c|}{ Total Kjeldahl nitrogen } \\
\hline 0.61057 & 0.694 & 12 & 1.5759 & 1.5055 & - & 0.8309 & 一 & -0.2587 & -0.1209 \\
\hline \multicolumn{10}{|c|}{ Total organic nitrogen } \\
\hline 0.51128 & 0.715 & 11 & -0.3187 & 1.7021 & - & 1.0415 & - & -0.3502 & 0.5939 \\
\hline \multicolumn{10}{|c|}{ Total ammonia nitrogen } \\
\hline 0.64878 & 0.583 & 10 & 1.6432 & 1.2254 & - & -0.0024 & - & -0.1950 & -0.4100 \\
\hline \multicolumn{10}{|c|}{ Total inorganic nitrogen } \\
\hline 0.20918 & 0.948 & 12 & 2.1060 & 1.4223 & - & 0.2951 & - & 0.1310 & 0.2797 \\
\hline \multicolumn{10}{|c|}{ Total phosphorus } \\
\hline 0.87464 & 0.303 & 12 & -1.6383 & 0.7019 & - & 1.2450 & - & -0.2464 & 0.1349 \\
\hline \multicolumn{10}{|c|}{ Total orthophosphorus } \\
\hline- & - & - & - & - & - & - & - & - & - \\
\hline
\end{tabular}

Boggy Branch near Wilmer, 02479960 (site BOG)

\begin{tabular}{|c|c|c|c|c|c|c|c|c|c|}
\hline $\mathbf{s}$ & $r^{2}$ & n & $\beta_{0}$ & $\beta_{1}$ & $\beta_{2}$ & $\beta_{3}$ & $\beta_{4}$ & $\beta_{5}$ & $\beta_{6}$ \\
\hline \multicolumn{10}{|c|}{ Total nitrogen } \\
\hline 0.33084 & 0.949 & 12 & 1.4754 & 1.2912 & 0.3733 & -0.0992 & -1.3389 & -0.2691 & -0.2252 \\
\hline \multicolumn{10}{|c|}{ Total Kjeldahl nitrogen } \\
\hline 0.38391 & 0.912 & 12 & 1.2347 & 1.3736 & - & -1.1838 & - & -0.1122 & -0.6940 \\
\hline \multicolumn{10}{|c|}{ Total organic nitrogen } \\
\hline 0.58766 & 0.720 & 11 & -1.7646 & 0.8351 & - & 1.0541 & - & 0.0528 & -0.1367 \\
\hline \multicolumn{10}{|c|}{ Total ammonia nitrogen } \\
\hline 0.41959 & 0.929 & 11 & 1.9234 & 1.1463 & 0.7731 & 0.0081 & -11.8689 & -1.0106 & -0.1948 \\
\hline \multicolumn{10}{|c|}{ Total inorganic nitrogen } \\
\hline 0.30845 & 0.921 & 12 & 0.1871 & 1.3184 & - & 0.3513 & - & -0.3106 & 0.2623 \\
\hline \multicolumn{10}{|c|}{ Total phosphorus } \\
\hline 0.35835 & 0.461 & 12 & -1.6876 & 0.2324 & - & 0.4350 & - & 0.0446 & 0.0386 \\
\hline \multicolumn{10}{|c|}{ Total orthophosphorus } \\
\hline- & - & - & - & - & - & - & - & - & - \\
\hline
\end{tabular}

Crooked Creek near Fairview, 02479980 (site CRO)

\begin{tabular}{|c|c|c|c|c|c|c|c|c|c|}
\hline $\mathbf{s}$ & $r^{2}$ & n & $\beta_{0}$ & $\beta_{1}$ & $\beta_{2}$ & $\beta_{3}$ & $\beta_{4}$ & $\beta_{5}$ & $\beta_{6}$ \\
\hline \multicolumn{10}{|c|}{ Total nitrogen } \\
\hline 0.27019 & 0.831 & 33 & 3.6626 & 1.2274 & -0.0626 & -0.0019 & -0.0078 & -0.1549 & -0.0960 \\
\hline \multicolumn{10}{|c|}{ Total Kjeldahl nitrogen } \\
\hline 0.49310 & 0.697 & 48 & 2.5244 & 1.5384 & 0.0311 & -0.0803 & -0.0009 & -0.0303 & -0.3407 \\
\hline \multicolumn{10}{|c|}{ Total organic nitrogen } \\
\hline 0.46168 & 0.715 & 47 & 0.0032 & 1.4031 & -0.0448 & 0.0501 & -0.0225 & 0.2067 & -0.1162 \\
\hline \multicolumn{10}{|c|}{ Total ammonia nitrogen } \\
\hline 0.44554 & 0.753 & 31 & 2.9074 & 1.5571 & -0.0208 & -0.0181 & -0.0033 & -0.2773 & -0.2374 \\
\hline \multicolumn{10}{|c|}{ Total inorganic nitrogen } \\
\hline 0.47087 & 0.374 & 48 & 2.4798 & 0.7253 & 0.0558 & -0.0406 & 0.0168 & 0.0326 & -0.0527 \\
\hline \multicolumn{10}{|c|}{ Total phosphorus } \\
\hline 0.71127 & 0.560 & 48 & 0.0566 & 1.7386 & - & -0.0052 & 一 & 0.1320 & 0.0004 \\
\hline \multicolumn{10}{|c|}{ Total orthophosphorus } \\
\hline 0.37663 & 0.683 & 45 & -0.7975 & 1.2952 & - & -0.0546 & - & -0.0929 & 0.0463 \\
\hline
\end{tabular}


Table 9. Regression summary for the seven-parameter, log-linear model used to estimate nutrient concentrations at selected sites in the Converse Lake watershed-Continued

[s, standard deviation of the residuals from ordinary least squares fit; $\mathrm{r}^{2}$, coefficient of determination; $\mathrm{n}$, number of observations used to fit the model; $\beta_{0}$, constant; $\beta_{1}$, coefficient of natural logarithm of streamflow; $\beta_{2}$, coefficient of natural logarithm of streamflow, squared; $\beta_{3}$, coefficient of time; $\beta_{4}$, coefficient of time, squared; $\beta_{5}$, coefficient of sine (time); $\beta_{6}$, coefficient of cosine (time); bold indicates coefficients with an absolute T value greater than 2 , which indicates significance; - , no data]

Hamilton Creek at Snow Road near Semmes, 02480002 (site HAM)

\begin{tabular}{|c|c|c|c|c|c|c|c|c|c|}
\hline $\mathbf{s}$ & $r^{2}$ & $\mathrm{n}$ & $\beta_{0}$ & $\beta_{1}$ & $\beta_{2}$ & $\beta_{3}$ & $\beta_{4}$ & $\beta_{5}$ & $\beta_{6}$ \\
\hline \multicolumn{10}{|c|}{ Total nitrogen } \\
\hline 0.12143 & 0.930 & 28 & 4.0483 & 0.8320 & 0.0846 & -0.0389 & -0.0025 & -0.0174 & -0.0070 \\
\hline \multicolumn{10}{|c|}{ Total Kjeldahl nitrogen } \\
\hline 0.34478 & 0.789 & 47 & 3.0790 & $\begin{array}{l}1.5212 \\
\text { Total or }\end{array}$ & $\begin{array}{c}-0.0292 \\
\text { c nitroge }\end{array}$ & -0.0974 & -0.0051 & -0.0541 & -0.1981 \\
\hline 0.44160 & 0.706 & 46 & 1.0568 & \multicolumn{5}{|c|}{ Total ammonia nitrogen } & -0.0826 \\
\hline 0.30069 & \multicolumn{8}{|c|}{ Total inorganic nitrogen } & -0.0766 \\
\hline \multicolumn{10}{|c|}{ Total phosphorus } \\
\hline 0.77744 & \multicolumn{8}{|c|}{ Total orthophosphorus } & -0.2391 \\
\hline 0.24929 & 0.788 & 45 & -0.3123 & 1.0960 & - & -0.0172 & - & 0.0790 & -0.0700 \\
\hline
\end{tabular}

$\beta_{1}$ (table 9). A significant, positive relation between streamflow and nutrient concentration indicates that nonpoint sources are the dominant source of input. If the relation is significantly negative, the primary source of nutrients is point sources. Total nitrogen (except at site LON), total Kjeldahl nitrogen (except at site HAM), total organic nitrogen (except at site BOG), ammonia (except at site LON), total inorganic nitrogen, and total phosphorus (except at sites LON and BOG) exhibited a significant, positive relation with streamflow, indicating that the dominant source of nutrient input to the watershed is from nonpoint sources.

The seasonal variation of nutrient concentrations has been attributed to several natural and cultural factors, including seasonal changes in algal or aquatic macrophyte uptake, fertilizer applications, or temperature-driven nitrification processes. A significant seasonal pattern, independent of flow variation, was observed for total nitrogen, total Kjeldahl nitrogen, and ammonia at sites BIG and CRO; for total Kjeldahl nitrogen and total organic nitrogen at site COL; and for total Kjeldahl and inorganic nitrogen at site HAM.

Different land-use practices contribute different levels of nutrients by nonpoint sources. A study by Reckhow and others (1980) summarized literature values of nutrient export from a variety of nonpoint sources (table 10). The range in nutrient yields is due to differences in climate, soils, and land-management practices for each category.

Annual yields at all monitored sites in the Converse Lake watershed were computed for total phosphorus, total inorganic nitrogen, total Kjeldahl nitrogen, and total nitrogen for the 1991 water year when all sites had continuous streamflow record (table 11). The total phosphorus yields ranged from 0.10 (site LON) to 0.52 (site CRO) $(\mathrm{kg} / \mathrm{ha}) / \mathrm{yr}$, and total nitrogen yields ranged from 3.83 (site COL) to 8.45 (site BIG) (kg/ha)/yr (table 11). When compared to table 10, the computed total phosphorus yields for Big Creek, Collins Creek, Long Branch, and Boggy Branch are within the expected range for forested land with minor agriculture (pasture, crops, mixed agriculture). Crooked Creek (site CRO) and Hamilton Creek (site HAM) subbasins had higher residential and nonrow crop (plant nurseries) land use (table 4) and higher total phosphorus yields $(0.52$ and $0.40[\mathrm{~kg} / \mathrm{ha}] / \mathrm{yr}$, respectively) than the other tributary subbasins. Juniper Creek (site JUN) subbasin had a total phosphorus yield of $0.45(\mathrm{~kg} / \mathrm{ha}) / \mathrm{yr}$, which was within the range observed at Crooked and Hamilton Creek; however, little to no residential influence is present in Juniper Creek (table 4). The total nitrogen 
Table 10. Range in nutrient yields from nonpoint sources (modified from Reckhow and others, 1980)

\begin{tabular}{|c|c|c|c|c|}
\hline \multirow{2}{*}{$\begin{array}{l}\text { Dominant } \\
\text { land use }\end{array}$} & \multicolumn{4}{|c|}{ Nutrient yields, in kilograms per hectare per year } \\
\hline & Mean & Minimum & Median & Maximum \\
\hline & \multicolumn{3}{|c|}{ Total phosphorus export } & Th: \\
\hline Forest & 0.24 & 0.02 & 0.21 & 0.83 \\
\hline Row crops & 4.46 & 0.26 & 2.24 & 18.6 \\
\hline Nonrow crops & 1.08 & 0.10 & 0.76 & 2.90 \\
\hline Pasture & 1.50 & 0.14 & 0.81 & 4.90 \\
\hline Feedlots & 301 & 21.3 & 224 & 795 \\
\hline Mixed agriculture & 1.13 & 0.08 & 0.91 & 3.25 \\
\hline Urban & 1.91 & 0.19 & 1.10 & 6.23 \\
\hline \multicolumn{5}{|c|}{ Total nitrogen export } \\
\hline Forest & 2.86 & 1.38 & 2.46 & 6.26 \\
\hline Row crops & 16.1 & 2.10 & 9.00 & 79.6 \\
\hline Nonrow crops & 5.19 & 0.97 & 6.08 & 7.82 \\
\hline Pasture & 8.65 & 1.48 & 5.19 & 30.9 \\
\hline Feedlot & 3,110 & 681 & 2,920 & 7,980 \\
\hline Mixed agriculture & 16.5 & 2.82 & 14.3 & 41.5 \\
\hline Urban & 9.97 & 1.48 & 5.50 & 38.5 \\
\hline
\end{tabular}

Table 11. Annual nutrient loads and yields for selected tributary sites in the Converse Lake watershed for water year 1991 $[$-, no data $]$

\begin{tabular}{|c|c|c|c|c|c|c|c|c|c|}
\hline \multirow{2}{*}{$\begin{array}{c}\text { Site } \\
\text { label } \\
\text { (fig. 1) }\end{array}$} & \multirow[b]{2}{*}{$\begin{array}{l}\text { Station } \\
\text { name }\end{array}$} & \multicolumn{4}{|c|}{$\begin{array}{l}\text { Annual nutrient loads, } \\
\text { in kilograms }\end{array}$} & \multicolumn{4}{|c|}{$\begin{array}{c}\text { Annual nutrient yields, } \\
\text { in kilograms per hectare per year }\end{array}$} \\
\hline & & $\begin{array}{c}\text { Total } \\
\text { phosphorus }\end{array}$ & $\begin{array}{c}\text { Total } \\
\text { inorganic } \\
\text { nitrogen }\end{array}$ & $\begin{array}{c}\text { Total } \\
\text { Kjeldahl } \\
\text { nitrogen }\end{array}$ & $\begin{array}{l}\text { Total } \\
\text { nitrogen }\end{array}$ & $\begin{array}{c}\text { Total } \\
\text { phosphorus }\end{array}$ & $\begin{array}{c}\text { Total } \\
\text { inorganic } \\
\text { nitrogen }\end{array}$ & $\begin{array}{c}\text { Total } \\
\text { Kjeldahl } \\
\text { nitrogen }\end{array}$ & $\begin{array}{l}\text { Total } \\
\text { nitrogen }\end{array}$ \\
\hline $\mathrm{BIG}$ & Big Creek & 1,880 & 27,300 & 58,800 & 69,000 & 0.23 & 3.35 & 7.19 & 8.45 \\
\hline JUN & Juniper Creek & 1,080 & 6,360 & 6,390 & 2,410 & 0.45 & 2.66 & 2.68 & 5.59 \\
\hline COL & Collins Creek & 270 & 2,260 & 6,360 & 8,510 & 0.12 & 1.02 & 2.88 & 3.83 \\
\hline LON & Long Branch & 87.7 & 4,640 & 2,710 & 5,440 & 0.10 & 5.62 & 3.30 & 6.61 \\
\hline BOG & Boggy Branch & 76.7 & 1,580 & 5,520 & - & 0.11 & 2.14 & 7.45 & - \\
\hline $\mathrm{CRO}$ & Crooked Creek & 1,080 & 6,900 & 10,800 & 15,200 & 0.52 & 3.29 & 5.16 & 7.24 \\
\hline \multirow[t]{2}{*}{ HAM } & Hamilton Creek & 847 & 8,620 & 8,840 & 17,400 & 0.40 & 4.04 & 4.14 & 8.16 \\
\hline & TOTAL & 5,245 & 57,660 & 99,420 & 118,000 & - & - & - & - \\
\hline
\end{tabular}

yields at the tributary sites fell within the published range of forested, agricultural (pasture, nonrow crops), and urban land use.

The total annual nutrient loads to Converse Lake for the 1991 water year were $5,245 \mathrm{~kg}$ for total phosphorus, $57,660 \mathrm{~kg}$ for total inorganic nitrogen, $99,420 \mathrm{~kg}$ for total Kjeldahl nitrogen, and $118,000 \mathrm{~kg}$ for total nitrogen (table 11). The nutrient loads at Big Creek, Crooked Creek, and Hamilton Creek accounted for over 70 percent of the total load in the watershed. Big Creek had the highest nutrient loads, accounting for almost 60 percent of the total nitrogen and total Kjeldahl nitrogen, 47 percent of the total inorganic nitrogen, and 36 percent of total phosphorus loads. Crooked and Juniper Creeks each contributed
21 percent of the total phosphorus load in 1991, and Hamilton Creek contributed about 16 percent. Total phosphorus yields from the Crooked, Juniper, and Hamilton Creek subbasins are 2 to 5 times those of the other tributary subbasins.

Annual loads were computed for the 1991 to 1998 water years at the three gaged sites-Big Creek (table 12), Crooked Creek (table 13), and Hamilton Creek (table 14). During the study period, nutrient loads and yields at all three sites were highest in the 1991 and 1998 water years; nutrient loads and yields were lowest in the 1992 and 1994 water years, except for total inorganic nitrogen in 1995. The mean annual loads and yields represent the average annual contribution of nutrients to Converse Lake for the study 
Table 12. Annual and mean annual nutrient loads and yields for Big Creek (site BIG), Converse Lake watershed, water years 1991-98

[kg/d, kilogram per day; g/d, gram per day; (kg/ha)/yr, kilogram per hectare per year]

\begin{tabular}{|c|c|c|c|c|c|c|}
\hline \multicolumn{7}{|c|}{ Annual loads } \\
\hline Water year & $\begin{array}{l}\text { Orthophosphate } \\
\text { (kg/d) }\end{array}$ & $\begin{array}{c}\text { Total } \\
\text { phosphorus } \\
(\mathbf{k g} / \mathbf{d})\end{array}$ & $\begin{array}{c}\text { Total } \\
\text { inorganic } \\
\text { nitrogen } \\
(\mathrm{kg} / \mathrm{d})\end{array}$ & $\begin{array}{c}\text { Total } \\
\text { ammonia } \\
(\mathrm{g} / \mathrm{d})\end{array}$ & $\begin{array}{c}\text { Total } \\
\text { Kjeldahl } \\
\text { nitrogen } \\
\text { (kg/d } \\
\end{array}$ & $\begin{array}{c}\text { Total } \\
\text { nitrogen } \\
(\mathbf{k g} / \mathrm{d})\end{array}$ \\
\hline 1991 & 840 & 1,880 & 27,300 & 49.7 & 58,700 & 69,000 \\
\hline 1992 & 472 & 1,050 & 18,000 & 16.7 & 19,700 & 33,800 \\
\hline 1993 & 748 & 1,850 & 17,400 & 34.3 & 39,200 & 51,500 \\
\hline 1994 & 442 & 1,020 & 12,400 & 15.5 & 16,300 & 29,100 \\
\hline 1995 & 550 & 1,340 & 12,000 & 23.6 & 22,900 & 36,000 \\
\hline 1996 & 747 & 2,060 & 13,100 & 34.6 & 29,800 & 49,200 \\
\hline 1997 & 543 & 1,380 & 12,000 & 23.6 & 16,200 & 37,000 \\
\hline 1998 & 816 & 2,530 & 13,400 & 64.5 & 35,800 & 66,300 \\
\hline Mean annual & 645 & 1,640 & 15,700 & 32.8 & 29,800 & 46,500 \\
\hline \multicolumn{7}{|c|}{ Annual yields ([kg/hal/yr) } \\
\hline Water year & Orthophosphate & $\begin{array}{c}\text { Total } \\
\text { phosphorus }\end{array}$ & $\begin{array}{c}\text { Total } \\
\text { inorganic } \\
\text { nitrogen }\end{array}$ & $\begin{array}{c}\text { Total } \\
\text { ammonia }\end{array}$ & $\begin{array}{c}\text { Total } \\
\text { Kjeldahl } \\
\text { nitrogen }\end{array}$ & $\begin{array}{c}\text { Total } \\
\text { nitrogen }\end{array}$ \\
\hline 1991 & 0.103 & 0.230 & 3.35 & 0.0061 & 7.19 & 8.45 \\
\hline 1992 & 0.058 & 0.129 & 2.20 & 0.0020 & 2.42 & 4.15 \\
\hline 1993 & 0.092 & 0.226 & 2.13 & 0.0042 & 4.81 & 6.31 \\
\hline 1994 & 0.054 & 0.125 & 1.52 & 0.0019 & 2.00 & 3.56 \\
\hline 1995 & 0.067 & 0.164 & 1.48 & 0.0029 & 2.80 & 4.41 \\
\hline 1996 & 0.092 & 0.252 & 1.60 & 0.0042 & 3.65 & 6.03 \\
\hline 1997 & 0.067 & 0.169 & 1.48 & 0.0029 & 1.99 & 4.52 \\
\hline 1998 & 0.100 & 0.311 & 1.64 & 0.0079 & 4.38 & 8.13 \\
\hline Mean annual & 0.079 & 0.201 & 1.93 & 0.0040 & 3.66 & 5.70 \\
\hline
\end{tabular}

Table 13. Annual and mean annual nutrient loads and yields for Crooked Creek (site CRO), Converse Lake watershed, water years 1991-98

[kg/d, kilogram per day; g/d, gram per day; $(\mathrm{kg} / \mathrm{ha}) / \mathrm{yr}$, kilogram per hectare per year]

\begin{tabular}{|c|c|c|c|c|c|c|}
\hline \multicolumn{7}{|c|}{ Annual loads } \\
\hline Water year & $\begin{array}{l}\text { Orthophosphate } \\
(\mathbf{k g} / \mathrm{d})\end{array}$ & $\begin{array}{c}\text { Total } \\
\text { phosphorus } \\
\text { (kg/d) }\end{array}$ & $\begin{array}{c}\text { Total } \\
\text { inorganic } \\
\text { nitrogen } \\
\text { (kg/d) }\end{array}$ & $\begin{array}{c}\text { Total } \\
\text { ammonia } \\
(\mathrm{g} / \mathrm{d})\end{array}$ & $\begin{array}{c}\text { Total } \\
\text { Kjeldahl } \\
\text { nitrogen } \\
\text { (kg/d) }\end{array}$ & $\begin{array}{c}\text { Total } \\
\text { nitrogen } \\
(\mathbf{k g} / \mathbf{d})\end{array}$ \\
\hline 1991 & 283 & 1,080 & 6,890 & 9.49 & 10,800 & 15,200 \\
\hline 1992 & 154 & 480 & 4,620 & 4.93 & 4,820 & 9,580 \\
\hline 1993 & 210 & 850 & 4,860 & 7.12 & 6,630 & 13,300 \\
\hline 1994 & 115 & 366 & 3,600 & 4.62 & 3,970 & 8,800 \\
\hline 1995 & 173 & 913 & 3,970 & 6.34 & 5,420 & 11,600 \\
\hline 1996 & 212 & 1,030 & 4,570 & 7.79 & 5,820 & 14,200 \\
\hline 1997 & 215 & 1,130 & 5,150 & 10.5 & 7,890 & 16,300 \\
\hline 1998 & 306 & 1,890 & 5,880 & 10.0 & 6,690 & 17,570 \\
\hline Mean annual & 208 & 967 & 4,940 & 7.59 & 6,510 & 13,300 \\
\hline \multicolumn{7}{|c|}{ Annual yields ([kg/hal/yr) } \\
\hline Water year & Orthophosphate & $\begin{array}{c}\text { Total } \\
\text { phosphorus }\end{array}$ & $\begin{array}{c}\text { Total } \\
\text { inorganic } \\
\text { nitrogen }\end{array}$ & $\begin{array}{c}\text { Total } \\
\text { ammonia }\end{array}$ & $\begin{array}{c}\text { Total } \\
\text { Kjeldahl } \\
\text { nitrogen }\end{array}$ & $\begin{array}{c}\text { Total } \\
\text { nitrogen }\end{array}$ \\
\hline 1991 & 0.135 & 0.517 & 3.29 & 0.0045 & 5.16 & 7.24 \\
\hline 1992 & 0.0733 & 0.229 & 2.21 & 0.0024 & 2.30 & 4.58 \\
\hline 1993 & 0.100 & 0.406 & 2.32 & 0.0034 & 3.17 & 6.34 \\
\hline 1994 & 0.0549 & 0.179 & 1.72 & 0.0022 & 1.90 & 4.21 \\
\hline 1995 & 0.0826 & 0.436 & 1.89 & 0.0030 & 2.59 & 5.54 \\
\hline 1996 & 0.101 & 0.492 & 2.18 & 0.0037 & 2.78 & 6.80 \\
\hline 1997 & 0.103 & 0.540 & 2.46 & 0.0050 & 3.77 & 7.79 \\
\hline 1998 & 0.146 & 0.903 & 2.81 & 0.0048 & 3.19 & 8.40 \\
\hline Mean annual & 0.100 & 0.462 & 2.36 & 0.0036 & 3.11 & 6.36 \\
\hline
\end{tabular}


Table 14. Annual and mean annual nutrient loads and yields for Hamilton Creek (site HAM), Converse Lake watershed, water years 1991-98

[kg/d, kilogram per day; g/d, gram per day; (kg/ha)/yr, kilogram per hectare per year]

\begin{tabular}{|c|c|c|c|c|c|c|}
\hline \multicolumn{7}{|c|}{ Annual loads } \\
\hline Water year & $\begin{array}{l}\text { Orthophosphate } \\
\text { (kg/d) }\end{array}$ & $\begin{array}{c}\text { Total } \\
\text { phosphorus } \\
\text { (kg/d) }\end{array}$ & $\begin{array}{c}\text { Total } \\
\text { inorganic } \\
\text { nitrogen } \\
(\mathrm{kg} / \mathrm{d})\end{array}$ & $\begin{array}{c}\text { Total } \\
\text { ammonia } \\
(g / d)\end{array}$ & $\begin{array}{c}\text { Total } \\
\text { Kjeldahı } \\
\text { nitrogen } \\
(\mathbf{k g} / \mathrm{d})\end{array}$ & $\begin{array}{c}\text { Total } \\
\text { nitrogen } \\
(\mathbf{k g} / \mathrm{d})\end{array}$ \\
\hline 1991 & 225 & 857 & 8,610 & 8.41 & 8,820 & 17,400 \\
\hline 1992 & 171 & 469 & 8,120 & 5.44 & 5,300 & 14,100 \\
\hline 1993 & 196 & 686 & 8,080 & 6.22 & 6,230 & 15,300 \\
\hline 1994 & 142 & 405 & 7,470 & 4.08 & 3,990 & 12,150 \\
\hline 1995 & 191 & 795 & 7,700 & 5.51 & 5,630 & 14,300 \\
\hline 1996 & 237 & 960 & 8,450 & 6.56 & 6,350 & 16,300 \\
\hline 1997 & 211 & 901 & 8,400 & 5.64 & 5,720 & 14,700 \\
\hline 1998 & 342 & 1,950 & 9,010 & 6.93 & 6,340 & 20,300 \\
\hline Mean annual & 214 & 876 & 8,230 & 6.09 & 6,050 & 15,600 \\
\hline \multicolumn{7}{|c|}{ Annual yields ([kg/hal/yr) } \\
\hline Water year & Orthophosphate & $\begin{array}{c}\text { Total } \\
\text { phosphorus }\end{array}$ & $\begin{array}{c}\text { Total } \\
\text { inorganic } \\
\text { nitrogen }\end{array}$ & $\begin{array}{c}\text { Total } \\
\text { ammonia }\end{array}$ & $\begin{array}{c}\text { Total } \\
\text { Kjeldahi } \\
\text { nitrogen }\end{array}$ & $\begin{array}{c}\text { Total } \\
\text { nitrogen }\end{array}$ \\
\hline 1991 & 0.106 & 0.398 & 4.04 & 0.0039 & 4.14 & 8.16 \\
\hline 1992 & 0.0801 & 0.221 & 3.81 & 0.0026 & 2.49 & 6.64 \\
\hline 1993 & 0.0920 & 0.322 & 3.79 & 0.0029 & 2.93 & 7.17 \\
\hline 1994 & 0.0667 & 0.190 & 3.51 & 0.0019 & 1.87 & 5.71 \\
\hline 1995 & 0.0896 & 0.374 & 3.62 & 0.0026 & 2.64 & 6.73 \\
\hline 1996 & 0.111 & 0.451 & 3.97 & 0.0030 & 2.98 & 7.67 \\
\hline 1997 & 0.0993 & 0.423 & 3.95 & 0.0027 & 2.69 & 6.91 \\
\hline 1998 & 0.161 & 0.914 & 4.23 & 0.0033 & 2.98 & 9.54 \\
\hline Mean annual & 0.101 & 0.412 & 3.87 & 0.0029 & 2.84 & 7.32 \\
\hline
\end{tabular}

period. A combined mean annual load of $75,400 \mathrm{~kg}$ of total nitrogen, $36,950 \mathrm{~kg}$ of total Kjeldahl nitrogen, $28,870 \mathrm{~kg}$ of total inorganic nitrogen, and $3,480 \mathrm{~kg}$ of total phosphorus was contributed to the lake by these sites during the 1991 to 1998 water years. Of the combined loads, 62 percent of the total nitrogen, 70 percent of the total Kjeldahl nitrogen, 54 percent of the total inorganic nitrogen, and 47 percent of the total phosphorus originated from the forested subbasin of Big Creek. The more residential and agricultural subbasins of Crooked Creek and Hamilton Creek, however, yielded over twice the total phosphorus per hectare of land use (fig. 17). Crooked and Hamilton Creek subbasins also had higher total inorganic nitrogen yields. The mean annual nutrient yields for the three sites were averaged to obtain a watershed yield for each nutrient species- $0.0933(\mathrm{~kg} / \mathrm{ha}) / \mathrm{yr}$ for orthophosphate, $0.358(\mathrm{~kg} / \mathrm{ha}) / \mathrm{yr}$ for total phosphorus, $2.72(\mathrm{~kg} / \mathrm{ha}) / \mathrm{yr}$ for total inorganic nitrogen, $0.0035(\mathrm{~kg} / \mathrm{ha}) / \mathrm{yr}$ for total ammonia, $3.20(\mathrm{~kg} / \mathrm{ha}) / \mathrm{yr}$ for total Kjeldahl nitrogen, and $6.46(\mathrm{~kg} / \mathrm{ha}) / \mathrm{yr}$ for total nitrogen (fig. 17). The $103-\mathrm{mi}^{2}$ drainage area of the Converse Lake watershed is equivalent to 26,677 hectares. These estimated values were used to compute a mean annual nutrient contribution to Converse Lake (table 15).

Table 15. Estimated mean annual nutrient contributions to Converse Lake

[(kg/ha)/yr, kilogram per hectare per year; kg/yr, kilogram per year]

\begin{tabular}{|c|c|c|}
\hline \multirow{2}{*}{ Nutrient } & \multicolumn{2}{|c|}{$\begin{array}{c}\text { Nutrient contributions } \\
\text { to the watershed }\end{array}$} \\
\hline & $\begin{array}{c}\text { Yield }^{\mathrm{a}} \\
([\mathrm{kg} / \mathrm{ha}] / \mathrm{yr})\end{array}$ & $\begin{array}{l}\text { Load }^{6} \\
\text { (kg/yr) }\end{array}$ \\
\hline Orthophosphate & 0.0933 & 2,490 \\
\hline Total phosphorus & 0.358 & 9,550 \\
\hline Total inorganic nitrogen & 2.72 & 72,600 \\
\hline Total ammonia & 0.0035 & 93 \\
\hline Total Kjeldahl nitrogen & 3.20 & 85,400 \\
\hline Total nitrogen & 6.46 & 172,000 \\
\hline $\begin{array}{l}{ }^{\mathrm{a}} \text { Estimated by averagin } \\
\text { utrients listed in tables } 12,1 \\
{ }^{\mathrm{b}} \text { Estimated by multiply } \\
\text { vatershed). }\end{array}$ & $\begin{array}{l}\text { ean annual } \\
4 . \\
d \text { by } 26,677\end{array}$ & $\begin{array}{l}\text { he selected } \\
\text { (drainage area of }\end{array}$ \\
\hline
\end{tabular}




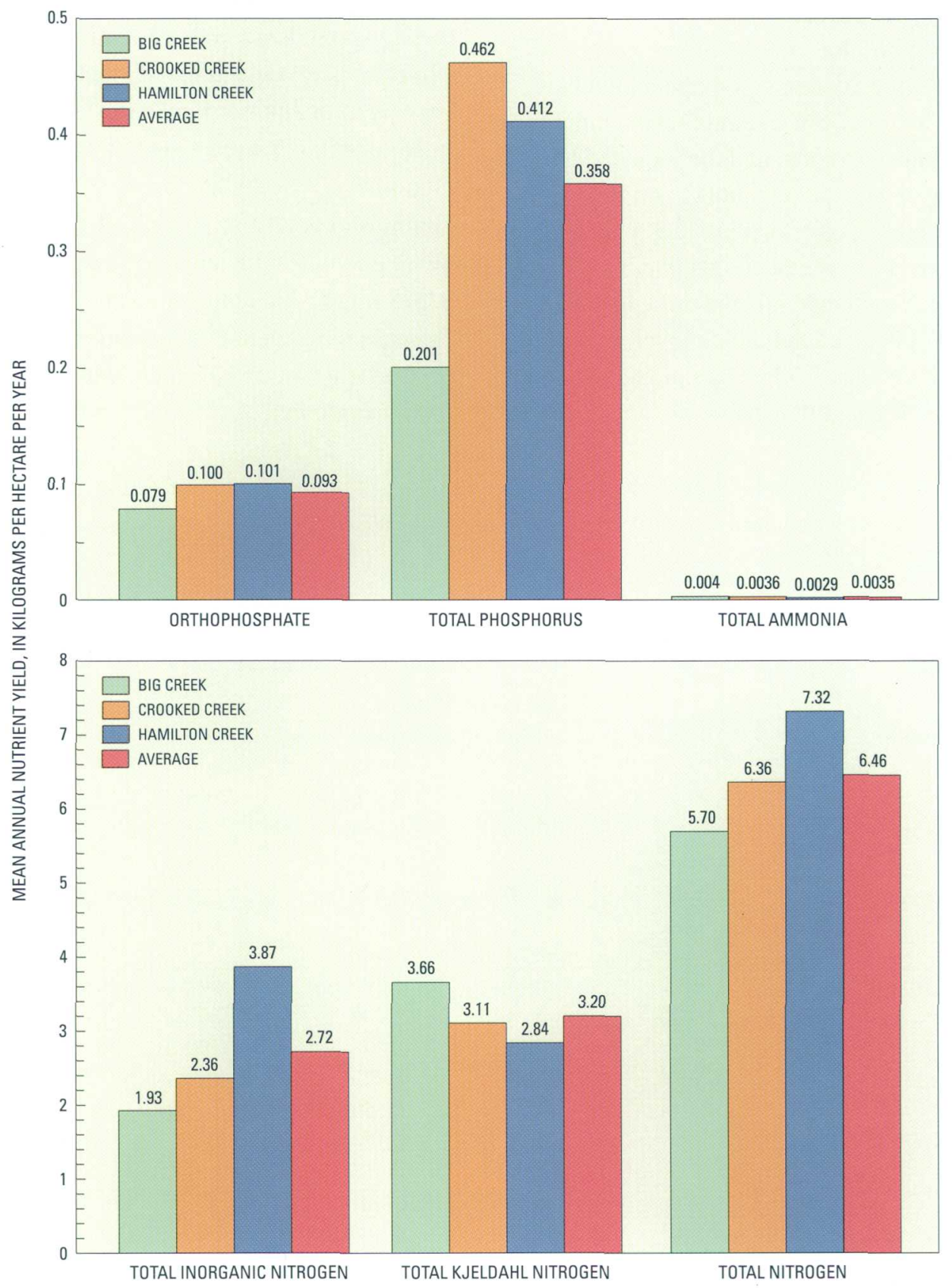

Figure 17. Mean annual nutrient yields for three sites in the Converse Lake watershed, 1990-98. 


\section{Eight-Year Trend Analysis}

Statistical significance levels were determined for each variable by the Kendall tau trend test, which accounts for seasonal variations in the constituent concentrations. The unadjusted trends were computed by using actual concentrations, and the adjusted trends were computed by using the residuals from the LOWESS relation (table 16). A two-sided probability or $p$-value was used to describe the attained significance level. Trend analysis was considered significant at a 95-percent confidence level when the trend test detected an actual or real trend and the estimate had a $p$-value less than 0.05 .
The trend analysis indicated little or no change in nutrient concentrations at the tributary and lake sites in the Converse Lake watershed from 1990 to 1998. Minimal decreases in total organic nitrogen were observed for Juniper Creek $(0.005[\mathrm{mg} / \mathrm{L}] / \mathrm{yr}-$ unadjusted), Crooked Creek (0.007 [mg/L]/yr), and Hamilton Creek (0.003 [mg/L]/yr). Collins Creek and Hamilton Creek also had small, but significant, decreases in total Kjeldahl nitrogen $(0.011$ and $0.005[\mathrm{mg} / \mathrm{L}] / \mathrm{yr}$, respectively). The only significant increase in nutrient concentrations was for total phosphorus at Long Branch, which was less than $0.001(\mathrm{mg} / \mathrm{L}) / \mathrm{yr}$.

Table 16. Results of the seasonal Kendall tau test for trends in unadjusted and flow-adjusted nutrient concentrations at selected sites in the Converse Lake watershed, 1990-98

[Trends reported in units of milligrams per liter per year; bold values represent significant trends with $p$-value less than or equal to 0.05 ; $<$, less than; -, not applicable]

\begin{tabular}{|c|c|c|c|c|c|c|}
\hline \multirow{2}{*}{ Constituent } & \multicolumn{3}{|c|}{ Unadjusted } & \multicolumn{3}{|c|}{ Adjusted } \\
\hline & Trend & tau value & $p$-value & Trend & tau value & $p$-value \\
\hline \multicolumn{7}{|c|}{ BIG CREEK (SITE BIG) } \\
\hline Total inorganic nitrogen & 0.010 & 0.22 & 0.180 & -0.004 & -0.13 & 0.431 \\
\hline Dissolved inorganic nitrogen & 0.010 & 0.24 & 0.158 & -0.002 & -0.09 & 0.603 \\
\hline Total ammonia & 0 & -0.15 & 0.358 & -0.001 & -0.16 & 0.347 \\
\hline Total organic nitrogen & -0.007 & -0.19 & 0.363 & -0.003 & -0.05 & 0.856 \\
\hline Total nitrogen & -0.005 & -0.10 & 0.692 & -0.038 & -0.15 & 0.497 \\
\hline Total Kjeldahl nitrogen & -0.009 & -0.13 & 0.530 & -0.008 & -0.21 & 0.287 \\
\hline Total phosphorus & 0 & 0.22 & 0.303 & 0.0011 & 0.28 & 0.240 \\
\hline \multicolumn{7}{|c|}{ JUNIPER CREEK (SITE JUN) } \\
\hline Total inorganic nitrogen & 0.006 & 0.13 & 0.506 & -0.001 & -0.03 & 0.933 \\
\hline Dissolved inorganic nitrogen & 0.005 & 0.13 & 0.506 & 0.002 & 0.04 & 0.868 \\
\hline Total ammonia & 0 & 0.18 & 0.278 & 0.0001 & 0.03 & 0.933 \\
\hline Total organic nitrogen & -0.005 & -0.39 & 0.022 & -0.004 & -0.17 & 0.362 \\
\hline Total nitrogen & -0.004 & -0.11 & 0.559 & 0.004 & 0.14 & 0.455 \\
\hline Total Kjeldahl nitrogen & 0 & -0.25 & 0.113 & -0.004 & -0.21 & 0.244 \\
\hline Total phosphorus & 0 & 0.29 & 0.052 & 0.00004 & 0.28 & 0.107 \\
\hline \multicolumn{7}{|c|}{ COLLINS CREEK (SITE COL) } \\
\hline Total inorganic nitrogen & 0.005 & 0.24 & 0.180 & 0.005 & 0.19 & 0.278 \\
\hline Dissolved inorganic nitrogen & 0.005 & 0.31 & 0.079 & 0.006 & 0.25 & 0.156 \\
\hline Total ammonia & 0 & -0.03 & 0.925 & 0 & 0 & 1.000 \\
\hline Total organic nitrogen & 0.001 & 0.04 & 1.000 & -0.030 & -0.42 & 0.151 \\
\hline Total nitrogen & -0.023 & -0.16 & 0.704 & -0.015 & -0.21 & 0.561 \\
\hline Total Kjeldahl nitrogen & -0.008 & -0.28 & 0.092 & -0.011 & -0.43 & 0.013 \\
\hline Total phosphorus & 0 & 0 & 1.000 & 0.0002 & 0.14 & 0.452 \\
\hline \multicolumn{7}{|c|}{ LONG BRANCH (SITE LON) } \\
\hline Total inorganic nitrogen & -0.013 & -0.04 & 0.911 & -0.029 & -0.20 & 0.374 \\
\hline Dissolved inorganic nitrogen & -0.013 & -0.04 & 0.911 & -0.035 & -0.20 & 0.374 \\
\hline Total ammonia & 0.0007 & 0.11 & 0.649 & -0.003 & 0.20 & 0.374 \\
\hline Total organic nitrogen & -0.009 & -0.13 & 0.581 & -0.008 & -0.15 & 0.505 \\
\hline Total nitrogen & -0.016 & -0.02 & 1.000 & -0.021 & -0.17 & 0.440 \\
\hline Total Kjeldahl nitrogen & -0.002 & -0.09 & 0.733 & -0.003 & -0.13 & 0.581 \\
\hline Total phosphorus & 0.002 & 0.41 & 0.023 & 0.0009 & 0.54 & 0.008 \\
\hline
\end{tabular}


Table 16. Results of the seasonal Kendall tau test for trends in unadjusted and flow-adjusted nutrient concentrations at selected sites in the Converse Lake watershed, 1990-98-Continued

[Trends reported in units of milligrams per liter per year; bold values represent significant trends with $p$-value less than or equal to $0.05 ;<$, less than; -, not applicable]

\begin{tabular}{|c|c|c|c|c|c|c|}
\hline \multirow{2}{*}{ Constituent } & \multicolumn{3}{|c|}{ Unadjusted } & \multicolumn{3}{|c|}{ Adjusted } \\
\hline & Trend & tau value & $p$-value & Trend & tau value & p-value \\
\hline \multicolumn{7}{|c|}{ BOGGY BRANCH (SITE BOG) } \\
\hline Total inorganic nitrogen & 0.001 & 0.12 & 0.644 & 0.001 & 0.13 & 0.618 \\
\hline Dissolved inorganic nitrogen & 0.002 & 0.11 & 0.653 & -0.001 & -0.07 & 0.812 \\
\hline Total ammonia & 0 & -0.02 & 1.000 & 0 & 0 & 1.000 \\
\hline Total organic nitrogen & 0.005 & 0.07 & 0.877 & 0.018 & 0.30 & 0.311 \\
\hline Total nitrogen & 0.002 & 0.07 & 0.881 & 0.004 & 0.20 & 0.515 \\
\hline Total Kjeldahl nitrogen & -0.003 & -0.08 & 0.880 & 0.005 & 0.04 & 1.000 \\
\hline Total phosphorus & 0.003 & 0.60 & 0.149 & 0.0004 & 0.25 & 0.743 \\
\hline \multicolumn{7}{|c|}{ CROOKED CREEK (SITE CRO) } \\
\hline Total inorganic nitrogen & -0.006 & -0.23 & 0.133 & -0.009 & -0.21 & 0.176 \\
\hline Dissolved inorganic nitrogen & -0.010 & -0.31 & 0.048 & -0.011 & -0.31 & $\mathbf{0 . 0 5 0}$ \\
\hline Total ammonia & 0 & 0.17 & 0.221 & 0.001 & 0.30 & 0.055 \\
\hline Total organic nitrogen & -0.005 & -0.21 & 0.1655 & -0.007 & -0.32 & 0.042 \\
\hline Total nitrogen & -0.011 & -0.17 & 0.274 & -0.017 & -0.28 & 0.079 \\
\hline Total Kjeldahl nitrogen & -0.001 & -0.12 & 0.441 & -0.006 & -0.27 & 0.091 \\
\hline Total phosphorus & 0 & 0.18 & 0.195 & 0.0003 & 0.15 & 0.343 \\
\hline \multicolumn{7}{|c|}{ HAMILTON CREEK (SITE HAM) } \\
\hline Total inorganic nitrogen & 0.004 & 0.11 & 0.524 & 0.003 & 0.15 & 0.362 \\
\hline Dissolved inorganic nitrogen & 0.001 & 0.04 & 0.832 & 0.003 & 0.09 & 0.624 \\
\hline Total ammonia & 0 & 0.03 & 0.880 & -0.001 & -0.15 & 0.360 \\
\hline Total organic nitrogen & -0.008 & -0.041 & 0.008 & -0.003 & -0.33 & 0.041 \\
\hline Total nitrogen & -0.010 & -0.24 & 0.137 & -0.008 & -0.22 & 0.183 \\
\hline Total Kjeldahl nitrogen & -0.008 & -0.40 & 0.195 & -0.005 & -0.40 & 0.011 \\
\hline Total phosphorus & 0 & 0.15 & 0.195 & 0 & 0.18 & 0.131 \\
\hline \multicolumn{7}{|c|}{ J.B. CONVERSE LAKE AT THE PUMP STATION (SITE LHAM) } \\
\hline Total inorganic nitrogen & 0.007 & 0.41 & 0.155 & - & - & - \\
\hline Dissolved inorganic nitrogen & 0.006 & 0.50 & 0.063 & - & - & - \\
\hline Total ammonia & 0.002 & 0.27 & 0.350 & - & - & - \\
\hline Total organic nitrogen & -0.012 & -0.45 & 0.115 & - & - & - \\
\hline Total nitrogen & 0 & 0 & 1.000 & - & - & - \\
\hline Total Kjeldahl nitrogen & -0.010 & -0.27 & 0.367 & - & - & - \\
\hline Total phosphorus & 0.002 & 0.32 & 0.248 & - & - & - \\
\hline
\end{tabular}

Trend analysis results suggest nutrient contributions from land-use activities have little effect on the reported increase in the trophic state of Converse Lake from 1984 to 1995. Evidence for this is the decreasing or insignificant change in nutrient concentrations from 1990 to 1998 identified in the trend analysis in conjunction with little or no substantial change in land use in the watershed from 1985 to 1995 (Reutebuch and others, 1997).

\section{Spatial and Temporal Distribution}

Nutrient concentrations at the tributary sites in the Converse Lake watershed showed only minor spatial variations (fig. 18). Long Branch had the greatest range in and median concentrations of total inorganic nitrogen $(0.57 \mathrm{mg} / \mathrm{L})$ and total nitrogen $(0.93 \mathrm{mg} / \mathrm{L})$ in the Converse Lake watershed. Collins Creek and the lake at the pump station (site LHAM) had the lowest median concentration of total nitrogen $(0.43 \mathrm{mg} / \mathrm{L})$. The lowest median concentrations of total inorganic nitrogen were at Boggy Branch $(0.12 \mathrm{mg} / \mathrm{L})$ and Converse Lake at the pump station $(0.09 \mathrm{mg} / \mathrm{L})$. Median concentrations of total Kjeldahl nitrogen were highest at Boggy Branch, Long Branch, and Big Creek $(0.30 \mathrm{mg} / \mathrm{L})$. Hamilton Creek, Juniper Creek, and Collins Creek had the lowest median concentrations of 

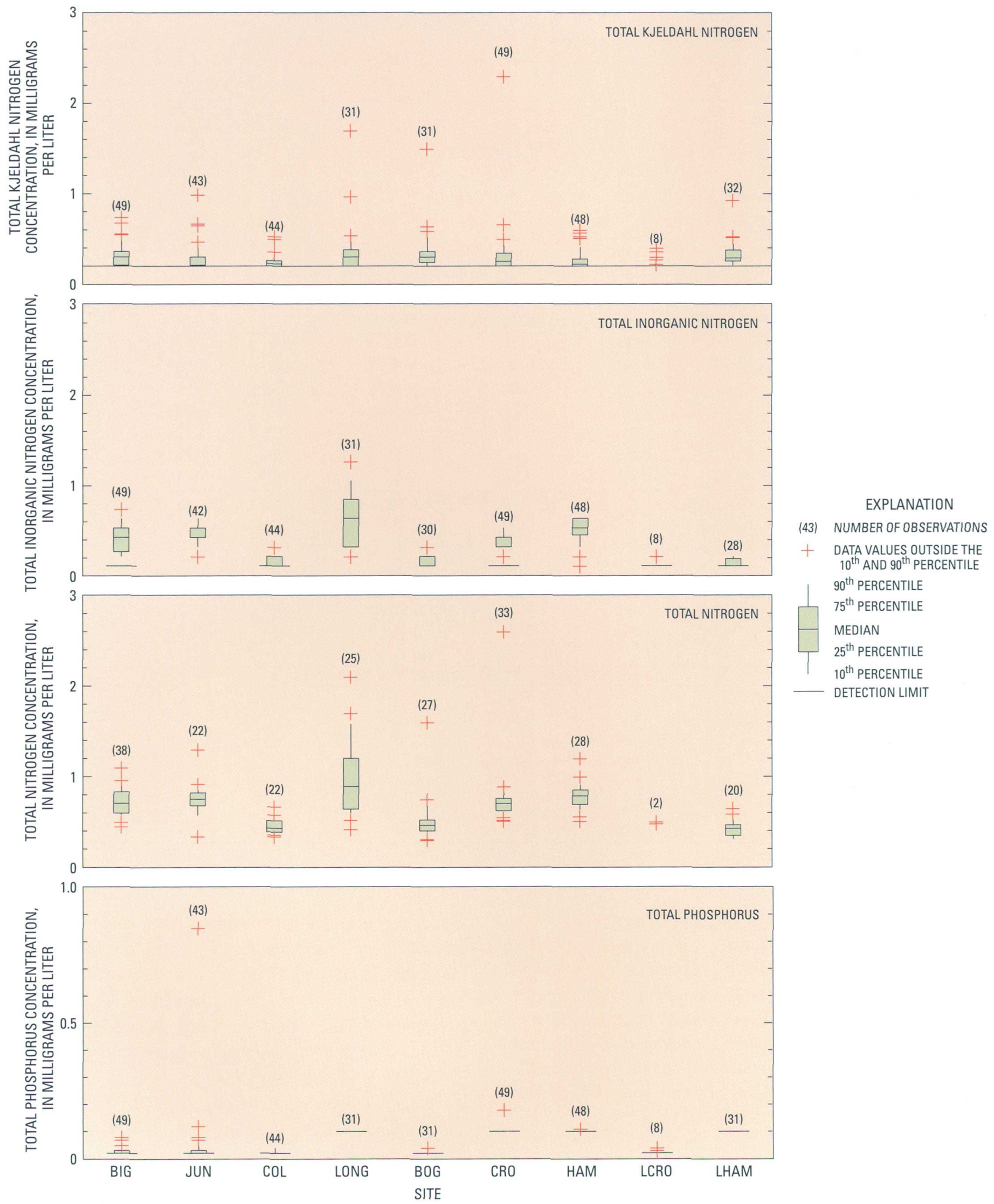

Figure 18. Boxplots of total Kjeldahl nitrogen, total inorganic nitrogen, total nitrogen, and total phosphorus concentrations at selected sites in the Converse Lake watershed, 1990-98. 
total Kjeldahl nitrogen $(0.22 \mathrm{mg} / \mathrm{L})$. Hamilton and Crooked Creeks had the highest median concentrations of total phosphorus $(0.02 \mathrm{mg} / \mathrm{L})$. The lake site at the pump station had similar median concentrations of total phosphorus (0.012).

Seasonal changes in nutrient concentrations related to biological uptake were not strongly evident at the tributary sites because of the added influence of streamflow. Within the lake, however, nutrient concentrations demonstrated seasonal patterns related to algal production (fig. 19). From 1996 to 1998 , chlorophyll $a$ levels in Converse Lake at the pump station increased from below $2 \mu \mathrm{g} / \mathrm{L}$ in February and March 1997 to a maximum of $9.7 \mu \mathrm{g} / \mathrm{L}$ in June 1997, indicating the period of greatest algal production. Beginning in August 1997, chlorophyll $a$ levels gradually decreased to a minimum of below $0.1 \mu \mathrm{g} / \mathrm{L}$ in January and February 1998. A second peak also was noted in October 1997 when chlorophyll $a$ levels increased to more than $6 \mu \mathrm{g} / \mathrm{L}$. During the summer and
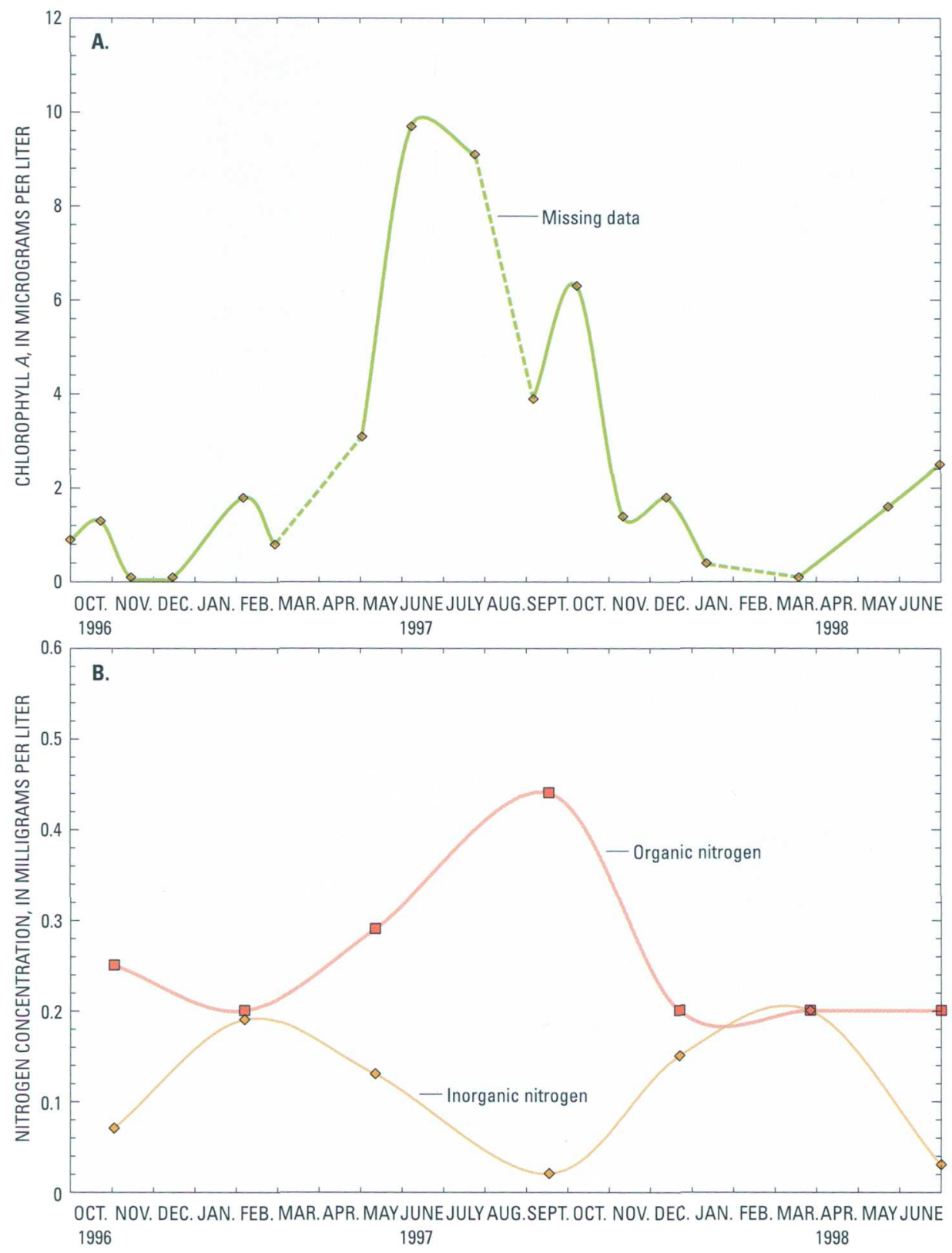

Figure 19. Seasonal variations in (A) chlorophyll $a$, and (B) organic and inorganic nitrogen concentrations in the Converse Lake watershed, 1996-98. 
fall of 1997 when algal production was greatest, total inorganic nitrogen concentration decreased to a minimum of less than $0.1 \mathrm{mg} / \mathrm{L}$ at the same time total organic nitrogen increased to a maximum of $0.44 \mathrm{mg} / \mathrm{L}$. This pattern suggests that during the peak of chlorophyll $a$ production, inorganic forms of nitrogen were assimilated by photoplankton and converted to the organic form (fig. 19).

\section{Comparison of Nutrient Loads with Trophic State of Lake}

The results of ADEM's Reservoir Water Quality Monitoring Program indicated that the trophic state of Converse Lake apparently increased from a TSI value of 37 (oligotrophic) in 1985 to a TSI value of 62 (eutrophic) in 1995 (table 17). The mean TSI for 1985 to 1995 was 50, which placed the average trophic state of Converse Lake between eutrophic and mesotrophic conditions. In 1997, the TSI for the lake decreased to
51 (Alabama Department of Environmental Management, 1999; table 17).

A simple trophic response of the lake to the nutrient loadings from the tributary subbasins was not evident during the study period. A surface phosphorus concentration of more than $0.024 \mathrm{mg} / \mathrm{L}$ in a lake is considered to indicate eutrophic conditions (Vollendweider, 1976), and would produce a Carlson's TSI of over 50 . To obtain a TSI of over 60 , the total phosphorus and nitrogen concentrations must be greater than 0.048 and $0.333 \mathrm{mg} / \mathrm{L}$, respectively, according to Carlson's TSI (Carlson, 1977) and the Lake Evaluation Index (Porcella and others, 1980). Converse Lake at the pump station (site LHAM) had a mean total phosphorus concentration of $0.02 \mathrm{mg} / \mathrm{L}$ and a mean total nitrogen concentration of $0.43 \mathrm{mg} / \mathrm{L}$, which categorizes the trophic state as mesotrophic during the study period 1990-98. These mean nutrient concentrations, however, do not include 1995 data

Table 17. Seasonal and annual change in trophic potential and response variables in Converse Lake, 1992-97

[-, no data; $\mu \mathrm{g} / \mathrm{L}$, microgram per liter; $\mathrm{mL}$, milliliter; $\mathrm{mg} / \mathrm{L}$, milligram per liter; $\mathrm{kg} / \mathrm{d}$, kilogram per day]

\begin{tabular}{|c|c|c|c|c|c|c|}
\hline \multirow{2}{*}{$\begin{array}{c}\text { Trophic potential } \\
\text { or } \\
\text { response variable }\end{array}$} & \multicolumn{2}{|c|}{1992} & \multicolumn{2}{|c|}{1995} & \multicolumn{2}{|c|}{1997} \\
\hline & Spring & Summer & Spring & Summer & Spring & Summer \\
\hline Carlson's Trophic State Index & - & $51^{\mathrm{a}}$ & - & $62^{\mathrm{a}}$ & - & $51^{b}$ \\
\hline Chlorophyll $a(\mu \mathrm{g} / \mathrm{L})$ & - & - & - & - & $\begin{array}{l}1.4^{\mathrm{c}} \\
2.9^{\mathrm{d}}\end{array}$ & $\begin{array}{l}7.1^{\mathrm{c}} \\
8.0^{\mathrm{d}}\end{array}$ \\
\hline $\begin{array}{l}\text { Phytoplankton density } \\
\text { (organisms } / \mathrm{mL} \text { ) }\end{array}$ & - & - & - & - & $1,886^{\mathrm{d}}$ & $1,485^{\mathrm{d}}$ \\
\hline In-lake total phosphorus $(\mathrm{mg} / \mathrm{L})$ & $0.013^{\mathrm{c}}$ & $0.020^{\mathrm{c}}$ & - & - & $\overline{-}^{\mathrm{c}} .009^{\mathrm{d}}$ & $\begin{array}{l}0.010^{\mathrm{c}} \\
0.013^{\mathrm{d}}\end{array}$ \\
\hline In-lake total orthophosphorus (mg/L) & $0.007^{\mathrm{c}}$ & $0.007^{\mathrm{c}}$ & - & - & $\begin{array}{l}0.005^{\mathrm{c}} \\
0.008^{\mathrm{d}}\end{array}$ & $\begin{array}{l}0.005^{\mathrm{c}} \\
0.006^{\mathrm{d}}\end{array}$ \\
\hline In-lake total nitrogen $(\mathrm{mg} / \mathrm{L})$ & $0.45^{\mathrm{c}}$ & $0.42^{\mathrm{c}}$ & - & - & $\begin{array}{l}0.42^{\mathrm{c}} \\
0.39^{\mathrm{d}}\end{array}$ & $\begin{array}{l}0.45^{\mathrm{c}} \\
0.37^{\mathrm{d}}\end{array}$ \\
\hline In-lake total inorganic nitrogen $(\mathrm{mg} / \mathrm{L})$ & $0.15^{\mathrm{c}}$ & $0.03^{\mathrm{c}}$ & - & - & $\begin{array}{l}0.13^{\mathrm{c}} \\
0.16^{\mathrm{d}}\end{array}$ & $\begin{array}{l}0.01^{c} \\
0.03^{d}\end{array}$ \\
\hline $\begin{array}{l}\text { Mean monthly total nitrogen loading } \\
(\mathrm{kg} / \mathrm{d})\end{array}$ & 107 & 101 & 259 & 176 & 156 & 314 \\
\hline $\begin{array}{l}\text { Mean monthly total phosphorus loading } \\
(\mathrm{kg} / \mathrm{d})\end{array}$ & 3.99 & 3.41 & 17.5 & 7.05 & 7.39 & 19.3 \\
\hline $\begin{array}{l}\text { Mean monthly total inorganic nitrogen } \\
\text { loading }^{\mathrm{e}}(\mathrm{kg} / \mathrm{d})\end{array}$ & 82.9 & 66.6 & 78.2 & 60.8 & 67.8 & 79.0 \\
\hline Land-use changes ${ }^{\mathrm{f}}$ & \multicolumn{2}{|c|}{ Forest re-growth } & \multicolumn{2}{|c|}{ Net loss of forest } & \multicolumn{2}{|c|}{ Forest re-growth } \\
\hline
\end{tabular}

${ }^{\mathrm{a}}$ From Alabama Department of Environmental Management (1996).

${ }^{\mathrm{b}}$ From Alabama Department of Environmental Management (1999).

${ }^{c}$ Average seasonal concentration at the lake for the pump station (USGS site LHAM).

${ }^{\mathrm{d}}$ Computed as an average of three sites in the Hamilton Creek embayment in Bayne and others (1998).

${ }^{\text {e}}$ From appendix 2; spring is the average of the monthly load rates for March, April, and May at Big, Hamilton, and Crooked Creeks; these averages are summed to get the mean monthly load. Summer is the average of the monthly load rates for June, July, and August.

${ }^{f}$ From Reutebuch and others (1997). 
when the TSI was over 60 because no data were collected in the lake from 1993 to 1995.

Nutrient concentrations and trophic response in the lake varied seasonally as well as annually (table 17). Trophic response variables and nutrient concentrations in the lake during the growing season were compared to the average monthly loading rates to the lake for spring and summer (computed from appendix 2 for Big, Crooked, and Hamilton Creeks) for 1992, 1995, and 1997. In general, nutrient loads were least in the fall, and greatest in the winter and spring. Monthly total nitrogen and total phosphorus loading rates to the lake from the tributaries for 1997 were much higher than for 1992; however, the higher rates appeared to have minimal influence on the in-lake concentrations and trophic response (fig. 20; table 17). The only differences between the TSI in 1995, when a value of 62 was well within eutrophic conditions, and the other 2 years when the TSI was 51, are relatively high total phosphorus and total nitrogen loading rates of 17.5 and $259 \mathrm{~kg} / \mathrm{d}$, respectively, in the spring of 1995. Although the rates of monthly loadings of total phosphorus and nitrogen were actually higher in the summer of 1997 (19.3 and $314 \mathrm{~kg} / \mathrm{d}$, respectively) than in the spring of 1995, the lake did not display a similar trophic response to the 1997 loadings.

Although the relation between the annual input of nutrients and the in-lake phosphorus and nitrogen concentrations can be complex, an attempt was made to identify a relation between these two conditions. The annual in-lake phosphorus concentrations can be estimated by empirical models developed from information collected by several researchers for a variety of lake types in a variety of geographic and climatic regions (Kirchner and Dillon, 1975; Vollenweider, 1975; Larsen and Mercier, 1976; Reckhow and Clements, 1984). Vollenweider (1968, 1969) developed an input-output (black box) model based on data from 20 natural lakes that established a correlation between annual areal nutrient loading and the mean lake depth for a given trophic state of the lake. Vollenweider (1975) modified the model to provide a measure of the phosphorus sedimentation or the amount of total phosphorus entering the lake that is

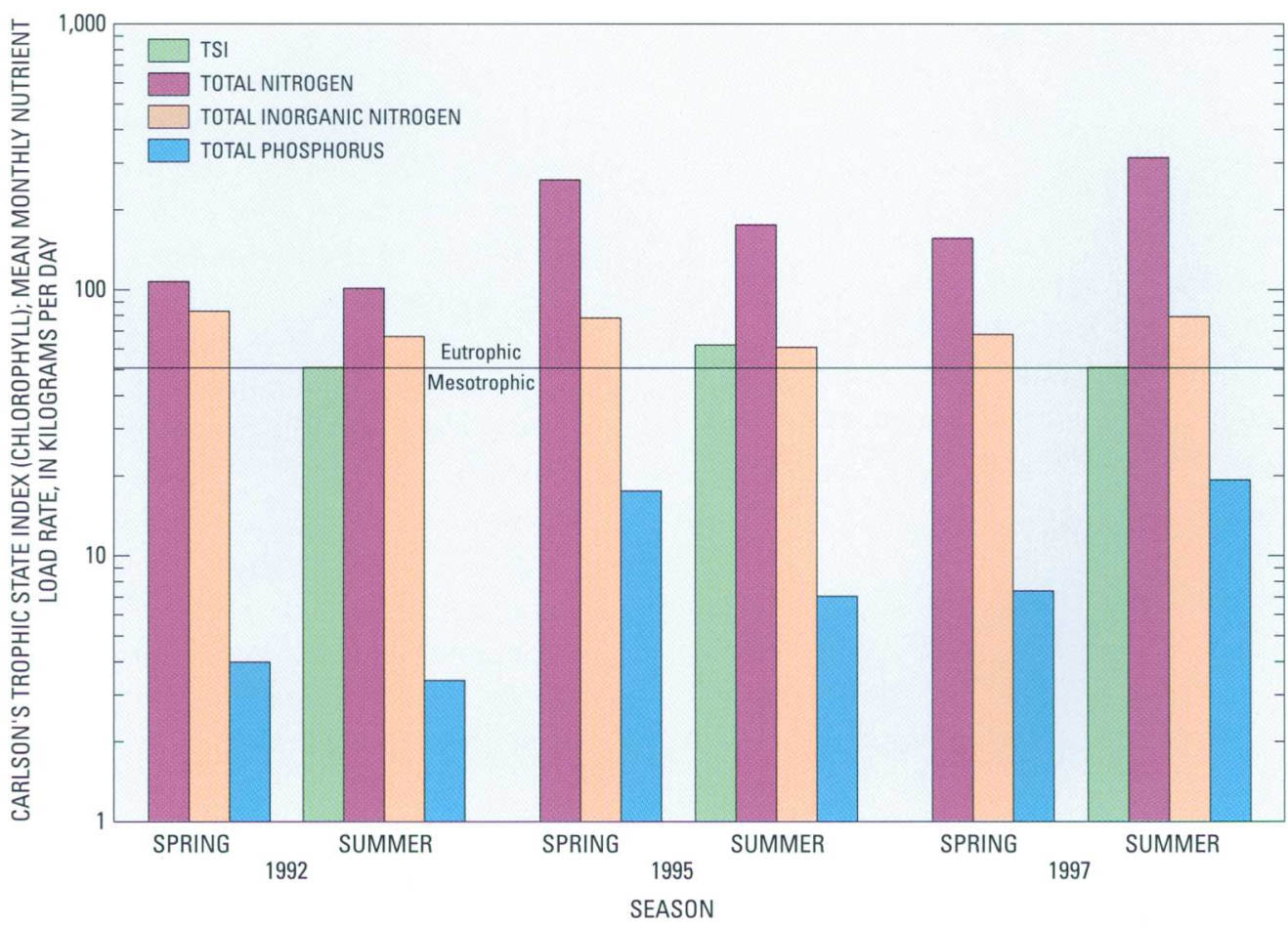

Figure 20. Temporal variations in nutrient loadings to the lake during the growing season and the lake response to these loadings. 
retained. This model computes the lake phosphorus concentration $(P)$, in milligrams per liter, by the formula

$$
P=\frac{L}{v_{s}+z / \tau}
$$

where

$L$ is the areal phosphorus loading (in grams per square meter per year),

$v_{s}$ is the apparent settling velocity (in meters per year),

$z$ is the mean lake depth (in meters), and

$\tau$ is the hydraulic residence time (in years).

The areal phosphorus loading $(L)$ is computed by the annual mass rate of phosphorus inflow $(M$; mean annual phosphorus load), in grams per year divided by the lake surface area $(A)$, in square meters. The model assumes immediate and complete mixing of the input phosphorus in the lake, outflow concentrations equal to lake concentrations, phosphorus sedimentation rate proportional to its concentration, and negligible seasonal fluctuations in loading.

Additional studies showed that the retention coefficient $(R)$ could be described as

$$
R=\frac{v_{s}}{\left(v_{s}+q_{s}\right)}
$$

where $q_{s}$ is the areal water loading, in meters per year (Chapra, 1975; Dillon and Kirchner, 1975). The areal water loading can be defined as the mean lake depth $(z)$, in meters, divided by the hydraulic residence time $(\tau)$, in years (Reckhow, 1979). The general model then becomes:

$$
P=\frac{L \tau}{z}(1-R)
$$

Vollenweider (1975) estimated the apparent settling velocity $\left(v_{s}\right)$ as $10 \mathrm{~m} / \mathrm{yr}$.

The mean annual total phosphorus load to Converse Lake was estimated to be $9,600 \mathrm{~kg} / \mathrm{yr}$ (table 15) or 9,600,000 g/yr. The areal water loading $\left(q_{s}\right)$ is $9.98 \mathrm{~m} / \mathrm{yr}$ (a mean depth of $14.4 \mathrm{ft}$ is equivalent to $4.39 \mathrm{~m}$; hydraulic residence time is 0.44 years). The lake surface area of 3,600 acres was converted to $14,569,200 \mathrm{~m}^{2}$. The areal water loading and apparent settling velocity were used as input to equation 4 to get a retention coefficient of 0.50 . The mean annual total phosphorus load was used in equation 5 to provide an estimated annual in-lake phosphorus concentration of $0.034 \mathrm{mg} / \mathrm{L}$, which was about twice as high as the observed mean concentration of $0.020 \mathrm{mg} / \mathrm{L}$ (appendix 1).

In summary, the lack-of-fit of the estimated in-lake phosphorus concentration from a simple inputoutput empirical model to the observed value in Converse Lake accentuates the need for a more robust model of lake water quality and trophic response. A more robust model would better explain the relation between annual nutrient contributions to Converse Lake from the tributaries and the lake's ability to assimilate these contributions by biomass uptake, sedimentation, and outflow.

\section{MICROBIOLOGICAL ASSESSMENT}

Fecal indicator bacteria are useful in assessing water quality because they are strongly correlated to the presence of waterborne pathogens (Myers and Wilde, 1999). Simple field methods are available to culture and enumerate fecal indicator bacteria; therefore, areas of possible fecal contamination can be readily identified. Two groups of bacteria commonly used as indicators are the fecal coliforms and fecal streptococci. These groups usually occur in the intestines of warm-blooded animals, but they also are able to live in other environments. Escherichia coli (E. coli), a subgroup of the fecal coliforms, is enteric in origin. The presence of $E$. coli in water is direct evidence of fecal contamination from warm-blooded animals and the possible presence of pathogens (Dufour, 1977).

Giardia and Cryptosporidium are protozoan parasites that infect the digestive tracts of human beings and other animals. Excretion of infected animals may contain resistant cysts (Giardia) or oocysts (Cryptosporidium) that can persist in the environment and remain infective after leaving the host (Rose, 1990).

Giardia is the cause of giardiasis, currently the most common waterborne disease in human beings (Hibler and Hancock, 1990). Cryptosporidium was first identified as a cause of disease in human beings in 1980 (Rose, 1990). Symptoms of infection by these protozoans are diarrhea and abdominal discomfort (U.S. Environmental Protection Agency, 1993). 
Documented waterborne occurrences include a 1987 outbreak in Carrollton, Ga., from a conventionally treated water supply (Rose, 1990), and another in Milwaukee, Wis., in 1993, which sickened 400,000 people and killed more than 100 people (Conrad, 1998). Because of the possibility of other outbreaks, the USEPA included testing of drinking water throughout the treatment and distribution process for Giardia cysts and Cryptosporidium oocysts in requirements for the Information Collection Rule (ICR; U.S. Environmental Protection Agency, 1999).

\section{Microbiological Analysis Methods and Approach}

Water samples were analyzed for fecal coliform and fecal streptococci bacteria quarterly from 1990 to 1996 and monthly from October 1996 to June 1998. Monthly analysis for $E$. coli was added in October 1996. All bacteria were cultured and enumerated using membrane filtration techniques described in chapter 7.1 of the USGS National Field Manual (Myers and Wilde, 1999). The following media were used for culturing: $\mathrm{m}$-FC for fecal coliforms, KF for fecal streptococci, and m-TEC for E. coli. Results were reported in colonies per 100 milliliters of water.

Basic summary statistics of fecal bacteria concentrations at each of the sites in the Converse Lake watershed were calculated (appendix 1). Boxplots of bacteria concentrations illustrate the range in concentrations found at each site. To further compare bacteria data to existing standards, the geometric mean concentration of each bacteria type was calculated. The geometric mean $(G)$ of a series of numbers $\left(x_{1}, x_{2}\right.$, $\mathrm{x}_{3} \ldots \mathrm{x}_{\mathrm{n}}$ ) is defined as follows:

$$
G=\left(x_{1} x_{2} x_{3} \ldots x_{n}\right)^{1 / n}
$$

Geometric means are used in many water-quality standards and criteria for concentrations of bacteria because the effects of outlier values on the mean are reduced.

The trends in concentrations of fecal coliform and fecal streptococcus were determined at one lake and seven tributary sites from bacteria data collected during the period October 1990 to June 1998. Trend analysis was performed by using the same LOWESS statistical technique described in the previous section. Statistical significance was set for trend estimates with a $p$-value of less than 0.05 .
The Converse Lake water-quality monitoring program included quarterly sampling for Giardia and Cryptosporidium at sites in the lake and in the watersupply system. Giardia sampling began in November 1990, and Cryptosporidium sampling began in June 1993. Water samples were shipped to BioVir Laboratories in Benicia, California, for analysis. Most of the samples collected during the study were analyzed for Giardia lamblia, the species of Giardia known to infect human beings, and for Cryptosporidium by using Standard Method 9711B; FA (Greenberg and others, 1992b). The Information Collection Rule (ICR) method, EPA 600/R-95/178, was used to detect Giardia sp. and Cryptosporidium in samples collected during May 1998. ICR results are reported as cysts per 100 liters of raw water, rather than a direct count of cysts observed. Methods information and analytical data for June 1993 to May 1998 are presented in appendix 3.

\section{Results of Microbiological Analysis}

The USEPA and the ADEM established standards and criteria for concentrations of fecal coliform bacteria for waters of varying uses (table 18). The ADEM established a use-classification system for State waters. Tributaries to Converse Lake are designated as suitable for fish and wildlife habitats, and the lake is classified as a public water supply.

The drinking-water standards are the maximum allowable levels of fecal bacteria in finished water, and are enforceable. The ADEM and USEPA criteria values are suggested limits or goals for fecal bacteria. All water-use classifications have criteria based on the maximum geometric mean bacterial density of five or more samples collected over 30 days at intervals of not less than 24 hours. Seasonal geometric mean criteria, which are effective June through September, apply to fish and wildlife and public water-supply uses. Even though geometric mean criteria were developed for use with several samples per month, the levels can provide a benchmark to assess the water quality of the Converse Lake watershed. Public water-supply, fish and wildlife, and agricultural and industrial water-supply water-use classifications also have maximum single-sample fecal coliform concentrations.

The USEPA-suggested criteria for $E$. coli for areas where swimming and whole-body contact sports occur are included in table 18. The USEPA suggests that the geometric mean of samples collected at a site 
Table 18. Standards and criteria for concentrations of fecal bacteria set by the Alabama Department of Environmental Management and the U.S. Environmental Protection Agency for various water-use classifications (U.S. Environmental Protection Agency, 1986; Alabama Department of Environmental Management, 2000)

[-, not applicable]

\begin{tabular}{|c|c|c|c|c|c|c|}
\hline \multirow[b]{2}{*}{ Type of bacteria } & \multirow[b]{2}{*}{$\begin{array}{l}\text { Drinking-water } \\
\text { standard }\end{array}$} & \multicolumn{5}{|c|}{$\begin{array}{l}\text { Fecal bacterial concentrations by water-use classifications, } \\
\text { in colonies per } 100 \text { milliliters }\end{array}$} \\
\hline & & $\begin{array}{l}\text { Outstanding } \\
\text { Alabama } \\
\text { water }\end{array}$ & $\begin{array}{l}\text { Public water } \\
\text { supply }\end{array}$ & $\begin{array}{l}\text { Swimming and } \\
\text { other whole-body } \\
\text { water contact } \\
\text { sports }\end{array}$ & $\begin{array}{c}\text { Fish } \\
\text { and } \\
\text { wildlife }\end{array}$ & $\begin{array}{c}\text { Agricultural and } \\
\text { industrial water } \\
\text { supply }\end{array}$ \\
\hline Fecal coliform & 0 & $200^{\mathrm{a}}$ & $\begin{array}{c}1,000^{a} \\
(200)^{b} \\
2,000^{c}\end{array}$ & $200^{\mathrm{a}}$ & $\begin{array}{c}1,000^{\mathrm{a}} \\
(200)^{\mathrm{b}} \\
2,000^{\mathrm{c}}\end{array}$ & $\begin{array}{l}2,000^{\mathrm{a}} \\
4,000^{\mathrm{c}}\end{array}$ \\
\hline Escherichia coli & 0 & - & - & $\begin{array}{c}126^{\mathrm{a}} \\
235 \text { to } 576^{\mathrm{d}}\end{array}$ & - & - \\
\hline
\end{tabular}

${ }^{\mathrm{a} B a c t e r i a l}$ concentrations shall not exceed a geometric mean of this value. The geometric mean shall be calculated from no less than five samples collected at a given station over a 30-day period at intervals not less than 24 hours.

${ }^{b}$ Values in parentheses are seasonal geometric mean limits effective during June through September to account for incidental water contact and recreational uses.

${ }^{\mathrm{c}}$ Maximum bacterial concentration not to be exceeded in any sample.

${ }^{\mathrm{d}}$ Range in U.S. Environmental Protection Agency recommended single-sample maximum allowable density for whole-body contact recreation for different frequencies of use, from designated beach areas to infrequently used whole-body contact recreational areas.

should not exceed $126 \mathrm{col} / 100 \mathrm{~mL}$, and that singlesample concentrations should not exceed $235 \mathrm{col} / 100$ $\mathrm{mL}$ in designated beach areas, or $576 \mathrm{col} / 100 \mathrm{~mL}$ in areas where waters are infrequently used for wholebody contact recreation (U.S. Environmental Protection Agency, 1986).

Summary statistics were calculated for each bacteria type at each site (appendix 1). Boxplots of the concentration data for each bacteria type, sorted by site, represent the data distribution graphically (fig. 21). Percentile values of bacterial concentrations were used to describe how often individual measurements exceeded criteria levels. Seventy-five percent of all measured fecal coliform concentrations at each of the sites were less than $1,000 \mathrm{col} / 100 \mathrm{~mL}$, the geometric mean criterion for public water supply and fish and wildlife water uses (red line, fig. 21A). Fifty percent of all measured fecal coliform concentrations at all sites except JUN and CRO were less than $200 \mathrm{col} / 100 \mathrm{~mL}$, the geometric mean criterion for swimming and wholebody contact water uses (blue line, fig. 21A).

Maximum fecal coliform levels at the two lake sites were below public water-supply criteria, but the maximum at site LHAM was above the criterion for swimming. At each of the tributary sites, at least 50 percent of all measured $E$. coli concentrations exceeded $126 \mathrm{col} / 100 \mathrm{~mL}$, the geometric mean criterion for swimmable waters (blue line, fig. 21C). At sites COL, CRO, HAM, and JUN, at least 50 percent of all measured $E$. coli concentrations exceeded $235 \mathrm{col} / 100 \mathrm{~mL}$, the single-sample criterion for designated beach areas (brown line, fig. 21C). At site JUN, 50 percent of all measured concentrations of E. coli exceeded $576 \mathrm{col} / 100 \mathrm{~mL}$, the single-sample limit for infrequent body contact (green line, fig. 21C). Concentrations of all bacteria types were lower at the two lake sites (LCRO and LHAM) than at the tributary sites (fig. 21). Also, the concentration range of $E$. coli appears to be higher at Juniper Creek (site JUN) than at other sites in the watershed.

Boxplots illustrate the seasonal concentrations of each bacteria type for all sites (fig. 22). Fecal coliform and $E$. coli had only minor variations in concentrations between seasons, whereas fecal streptococcus concentrations were somewhat greater during spring and summer. The difference in concentrations between seasons is probably due to temperature changes, which affect the survival rates of the fecal streptococci.

Median concentrations of each bacteria type were calculated by season for each site to examine seasonal effects on bacteria concentrations (table 19). At the majority of the sites, fecal coliform bacteria seem to be more abundant in summer than during the other seasons. Fecal streptococci were more abundant during spring and summer at individual sites. 

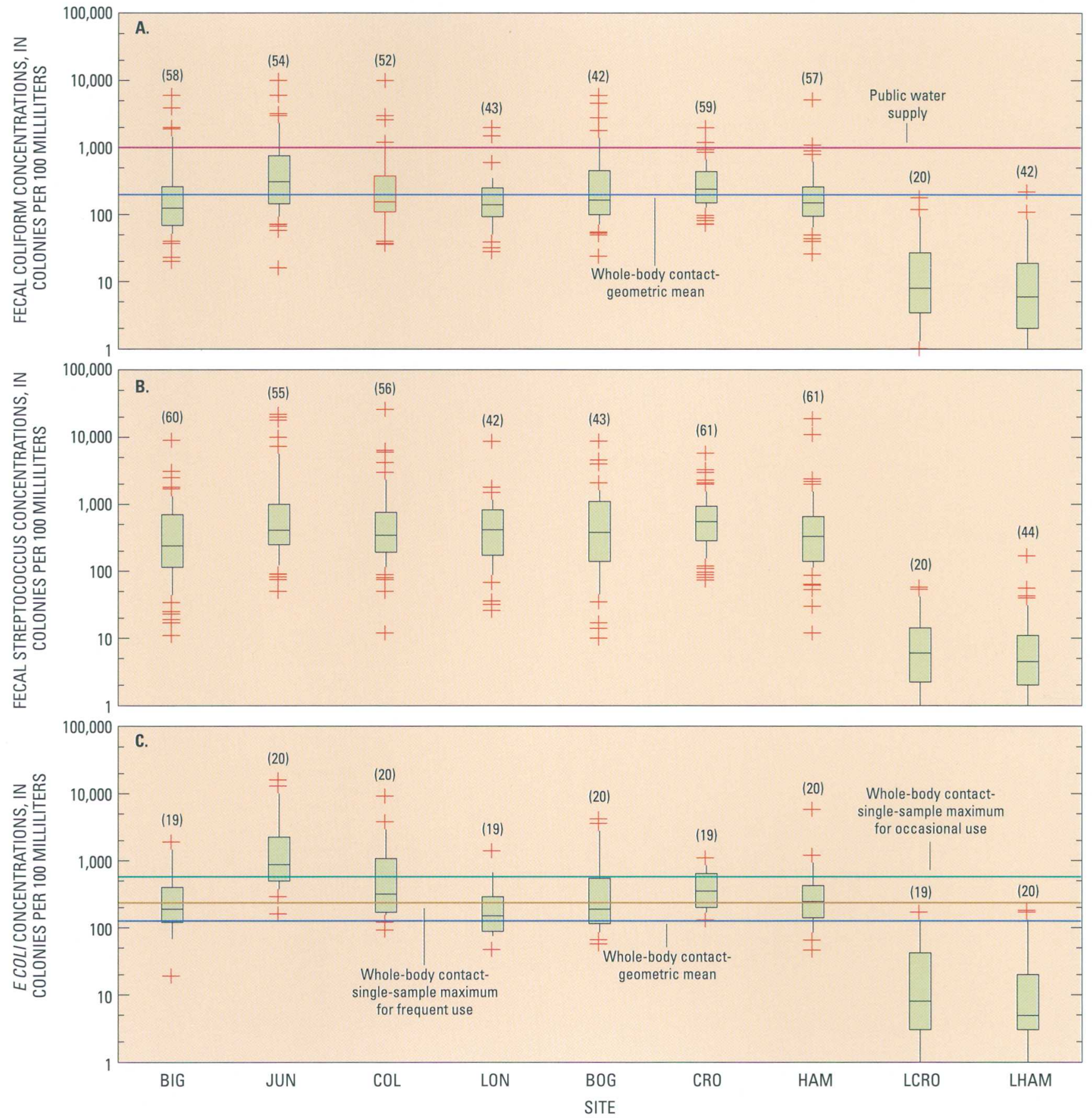

EXPLANATION

(19) NUMBER OF OBSERVATIONS

$+\quad$ Data VAlUES OUTSIDE THE $10^{\text {th }}$ AND $90^{\text {th }}$ PERCENTILE

$90^{\text {th }}$ PERCENTILE $75^{\text {th }}$ PERCENTILE

MEDIAN

$25^{\text {th }}$ PERCENTILE

$10^{\text {th }}$ PERCENTILE

Figure 21. Boxplots showing ranges of (A) fecal coliform, (B) fecal streptococcus, and (C) E. coli concentrations at selected sites in the Converse Lake watershed, 1990-98. 

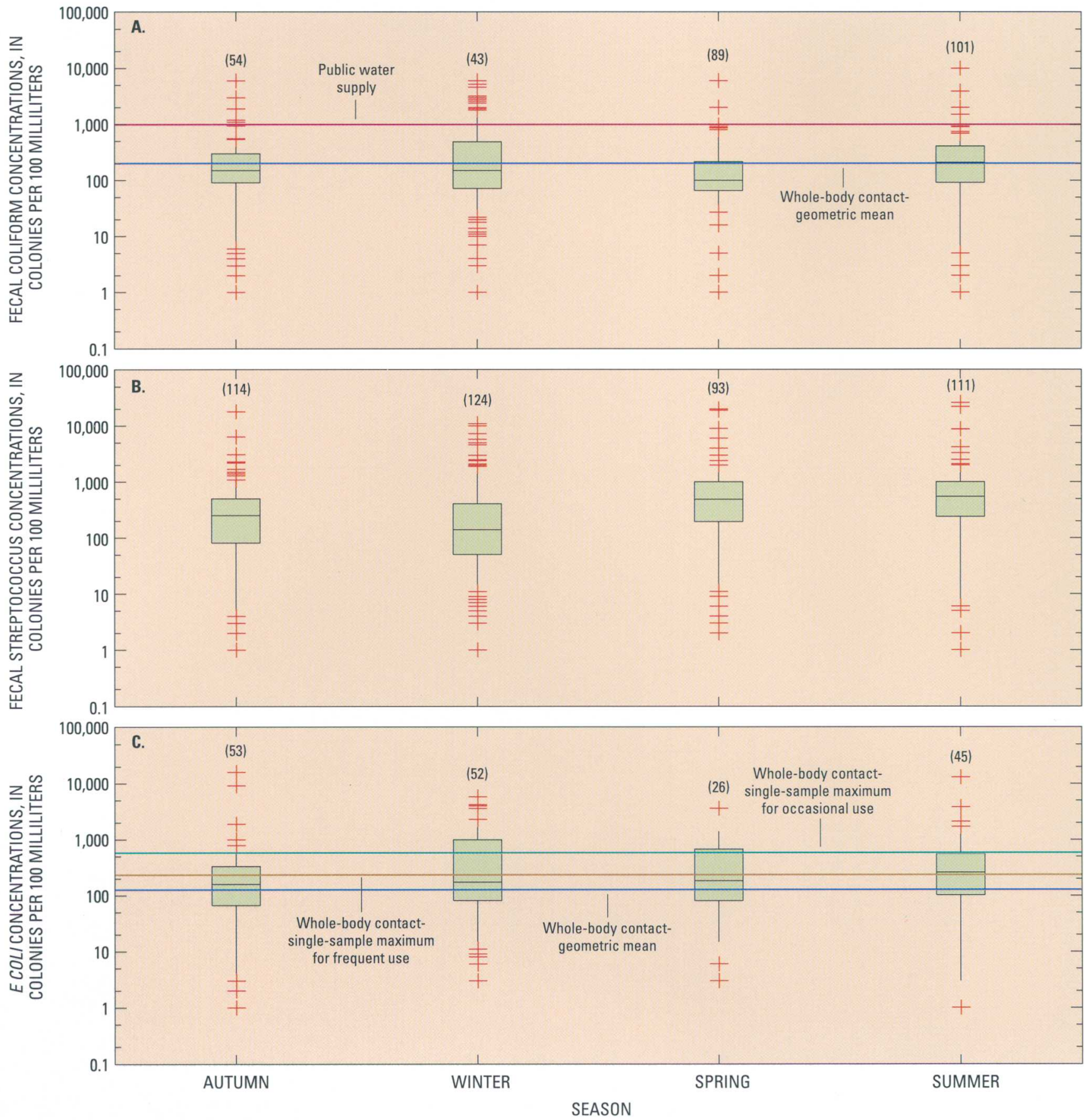

EXPLANATION

(19) NUMBER OF OBSERVATIONS

$+\quad$ data VAlues outside the $10^{\text {th }}$ AND $90^{\text {th }}$ PERCENTILE $90^{\text {th }}$ PERCENTILE $75^{\text {th }}$ PERCENTILE MEDIAN $25^{\text {th }}$ PERCENTILE $10^{\text {th }}$ PERCENTILE

Figure 22. Boxplots showing seasonal (A) fecal coliform, (B) fecal streptococcus, and (C) E. coli concentrations at selected sites in the Converse Lake watershed, 1990-98. 
Table 19. Seasonal median bacterial concentrations for selected sites in the Converse Lake watershed, 1990-98 [col/100 mL, colonies per 100 milliliters]

\begin{tabular}{|c|c|c|c|c|c|c|c|c|}
\hline \multirow[b]{2}{*}{$\begin{array}{l}\text { Site label } \\
\text { (fig. 1) }\end{array}$} & \multicolumn{2}{|c|}{ Spring } & \multicolumn{2}{|c|}{ Summer } & \multicolumn{2}{|c|}{ Autumn } & \multicolumn{2}{|c|}{ Winter } \\
\hline & $\begin{array}{c}\begin{array}{c}\text { Number } \\
\text { of } \\
\text { observations }\end{array} \\
\end{array}$ & Median & $\begin{array}{c}\begin{array}{c}\text { Number } \\
\text { of } \\
\text { observations }\end{array} \\
\end{array}$ & Median & $\begin{array}{c}\begin{array}{c}\text { Number } \\
\text { of } \\
\text { observations }\end{array} \\
\end{array}$ & Median & $\begin{array}{c}\text { Number } \\
\text { of } \\
\text { observations }\end{array}$ & Median \\
\hline & \multicolumn{8}{|c|}{ Fecal coliforms (col/100mL) } \\
\hline $\mathrm{BIG}$ & 13 & 69 & 14 & 200 & 15 & 130 & 16 & 145 \\
\hline JUN & 11 & 190 & 13 & 340 & 14 & 300 & 16 & 460 \\
\hline $\mathrm{COL}$ & 10 & 120 & 12 & 240 & 14 & 180 & 16 & 145 \\
\hline LON & 10 & 105 & 10 & 250 & 10 & 145 & 13 & 110 \\
\hline BOG & 9 & 150 & 10 & 205 & 10 & 160 & 13 & 170 \\
\hline CRO & 13 & 120 & 14 & 360 & 15 & 310 & 17 & 180 \\
\hline LCRO & 3 & 27 & 5 & 2 & 6 & 7 & 6 & 24 \\
\hline HAM & 12 & 140 & 13 & 160 & 15 & 140 & 17 & 160 \\
\hline \multirow[t]{2}{*}{ LHAM } & 8 & 2 & 10 & 6 & 12 & 5 & 12 & 13 \\
\hline & \multicolumn{8}{|c|}{ Fecal streptococci (col/100 mL) } \\
\hline BIG & 13 & 260 & 15 & 520 & 16 & 235 & 16 & 86 \\
\hline JUN & 12 & 670 & 14 & 935 & 13 & 250 & 16 & 295 \\
\hline $\mathrm{COL}$ & 12 & 630 & 14 & 370 & 14 & 260 & 16 & 245 \\
\hline LON & 9 & 660 & 11 & 700 & 10 & 295 & 12 & 102 \\
\hline BOG & 9 & 540 & 11 & 500 & 10 & 375 & 13 & 140 \\
\hline $\mathrm{CRO}$ & 13 & 700 & 15 & 740 & 16 & 530 & 17 & 220 \\
\hline LCRO & 3 & 9 & 5 & 1 & 6 & 6 & 6 & 13 \\
\hline HAM & 13 & 490 & 15 & 550 & 16 & 170 & 17 & 190 \\
\hline \multirow[t]{2}{*}{ LHAM } & 9 & 6 & 11 & 2 & 13 & 3 & 11 & 6 \\
\hline & \multicolumn{8}{|c|}{ Escherichia coli (col/100 mL) } \\
\hline BIG & 3 & 140 & 5 & 200 & 6 & 160 & 5 & 160 \\
\hline JUN & 3 & 790 & 5 & 1,600 & 6 & 485 & 6 & 2,150 \\
\hline $\mathrm{COL}$ & 3 & 170 & 5 & 1,500 & 6 & 210 & 6 & 620 \\
\hline LON & 3 & 83 & 5 & 290 & 5 & 120 & 6 & 140 \\
\hline BOG & 3 & 130 & 5 & 210 & 6 & 240 & 6 & 190 \\
\hline CRO & 3 & 350 & 5 & 540 & 6 & 370 & 5 & 300 \\
\hline LCRO & 2 & 24 & 5 & 3 & 6 & 7 & 6 & 48 \\
\hline HAM & 3 & 480 & 5 & 280 & 6 & 195 & 6 & 500 \\
\hline LHAM & 3 & 22 & 5 & 3 & 3 & 4 & 3 & 12 \\
\hline
\end{tabular}

Seasonal median values also can be compared to criteria to help determine when exceedances occur. At all sites in the watershed, median fecal coliform concentrations measured in spring were less than $200 \mathrm{col} / 100 \mathrm{~mL}$, the geometric mean criterion for swimmable waters. Median fecal coliform concentrations measured in summer were greater than or equal to $200 \mathrm{col} / 100 \mathrm{~mL}$ at sites BIG, JUN, COL, LON, BOG, and CRO. Median fecal coliform concentrations in autumn were greater than $200 \mathrm{col} / 100 \mathrm{~mL}$ at sites JUN and CRO. In winter, only site JUN had a median fecal coliform concentration above $200 \mathrm{col} / 100 \mathrm{~mL}$. None of the seasonal median fecal coliform concentrations was greater than $1,000 \mathrm{col} / 100 \mathrm{~mL}$, the public water-supply and fish and wildlife geometric mean criterion. Median values of fecal coliform concentrations in the lake sites were below all criteria throughout the year.

Median E. coli concentrations exceeded the geometric mean criterion of $126 \mathrm{col} / 100 \mathrm{~mL}$ at sites BIG, JUN, COL, BOG, CRO, and HAM during all seasons, and at site LON during summer and winter. Median E. coli concentrations exceeded the designated beach single-sample criterion of $235 \mathrm{col} / 100 \mathrm{~mL}$ at 
sites JUN and CRO during all seasons, at site HAM during spring, summer, and winter, at site COL during summer and winter, at site LON during summer, and at site BOG during autumn (table 19). Median concentrations exceeded the single-sample maximum of $576 \mathrm{col} / 100 \mathrm{~mL}$ for infrequently used whole-body contact recreation areas at site JUN during spring, summer, and winter and at site COL during summer. For all seasons, median $E$. coli concentrations at lake sites LCRO and LHAM were below all criteria.

Median concentrations of $E$. coli were lower at the lake sites in summer and autumn than during winter and spring, possibly because low flows in the tributaries prevented the bacteria from being transported to the lake before they naturally died off.

For comparison to criteria, geometric means of the measured concentrations of each bacteria type were calculated. Geometric means are summarized in table 20 , and geometric mean bacterial density is shown in figure 23.

Geometric mean concentrations of fecal coliform for the entire period of record were below all criteria levels at tributary sites BIG, LON, and HAM, and lake sites LCRO and LHAM (fig. 23A). Sites JUN, COL, BOG, and CRO exceeded the whole-body contact geometric mean criterion of $200 \mathrm{col} / 100 \mathrm{~mL}$. The geometric mean concentrations of fecal streptococci for the entire period of record are shown in figure 23B. Though no criteria currently (2001) exist for fecal streptococci, the high geometric mean concentrations found at sites JUN, COL, and CRO should be noted, as well as the low geometric means at the two lake sites, LCRO and LHAM.

The geometric mean of $E$. coli concentrations for the period October 1996 to June 1998 at all tributary sites exceeded the whole-body contact geometric mean criterion of $126 \mathrm{col} / 100 \mathrm{~mL}$; however, the geometric mean concentrations at the lake sites, LCRO and LHAM, were well below all criteria levels (fig. 23C). Sites JUN, COL, BOG, CRO, and HAM had geometric mean concentrations greater than the whole-body contact single-sample exceedance criterion for beach areas $(235 \mathrm{col} / 100 \mathrm{~mL})$. Site JUN had higher concentrations of $E$. coli than the other tributary sites (table 20).

To determine if criteria exceedances for fecal coliform were occurring at the same sites as $E$. coli exceedances, geometric mean concentrations for fecal coliform concentrations were determined for the same time period as that for the $E$. coli concentrations (figs. 23C, D). Six of the seven tributary sites exceeded the whole-body contact geometric mean criterion of $200 \mathrm{col} / 100 \mathrm{~mL}$ for fecal coliform. The geometric mean fecal coliform density of $921 \mathrm{col} / 100 \mathrm{~mL}$ at Juniper Creek (site JUN) approached the public watersupply and the fish and wildlife geometric mean criteria of $1,000 \mathrm{col} / 100 \mathrm{~mL}$.

Concentrations of fecal bacteria in the tributaries were elevated during the study period and may be cause for concern, especially in Juniper Creek.

Concentrations of indicator bacteria at the lake sites, however, were below all criteria, indicating the lake water was an acceptable source for drinking-water supply. Trend analyses of the fecal coliform and fecal streptococcus data showed significant increases in concentrations at Juniper Creek (site JUN; table 21) from 1990 to 1998 . These trends are of particular concern because median fecal coliform concentrations at Juniper Creek were already above the whole-body contact criteria during the same period (appendix 1).

Table 20. Geometric means of bacterial concentrations at sites in the Converse Lake watershed for the period October 1990-June 1998

\begin{tabular}{lrrrrrrrrr}
\hline \multirow{2}{*}{ Type of bacteria } & \multicolumn{10}{c}{ Concentrations, by site, in colonies per 100 milliliters } \\
\cline { 2 - 10 } & BIG & JUN & COL & LON & B0G & CRO & LCRO & HAM & LHAM \\
\hline Fecal coliform & 168 & 358 & 202 & 150 & 225 & 257 & 10 & 165 & 7 \\
Fecal streptococci & 263 & 573 & 407 & 361 & 361 & 522 & 7 & 346 & 5 \\
Escherichia coli & 216 & 1,185 & 454 & 173 & 262 & 375 & 10 & 272 & 8 \\
Fecal coliform 1996-98 & 245 & 921 & 395 & 199 & 285 & 313 & 10 & 231 & 10 \\
\hline
\end{tabular}




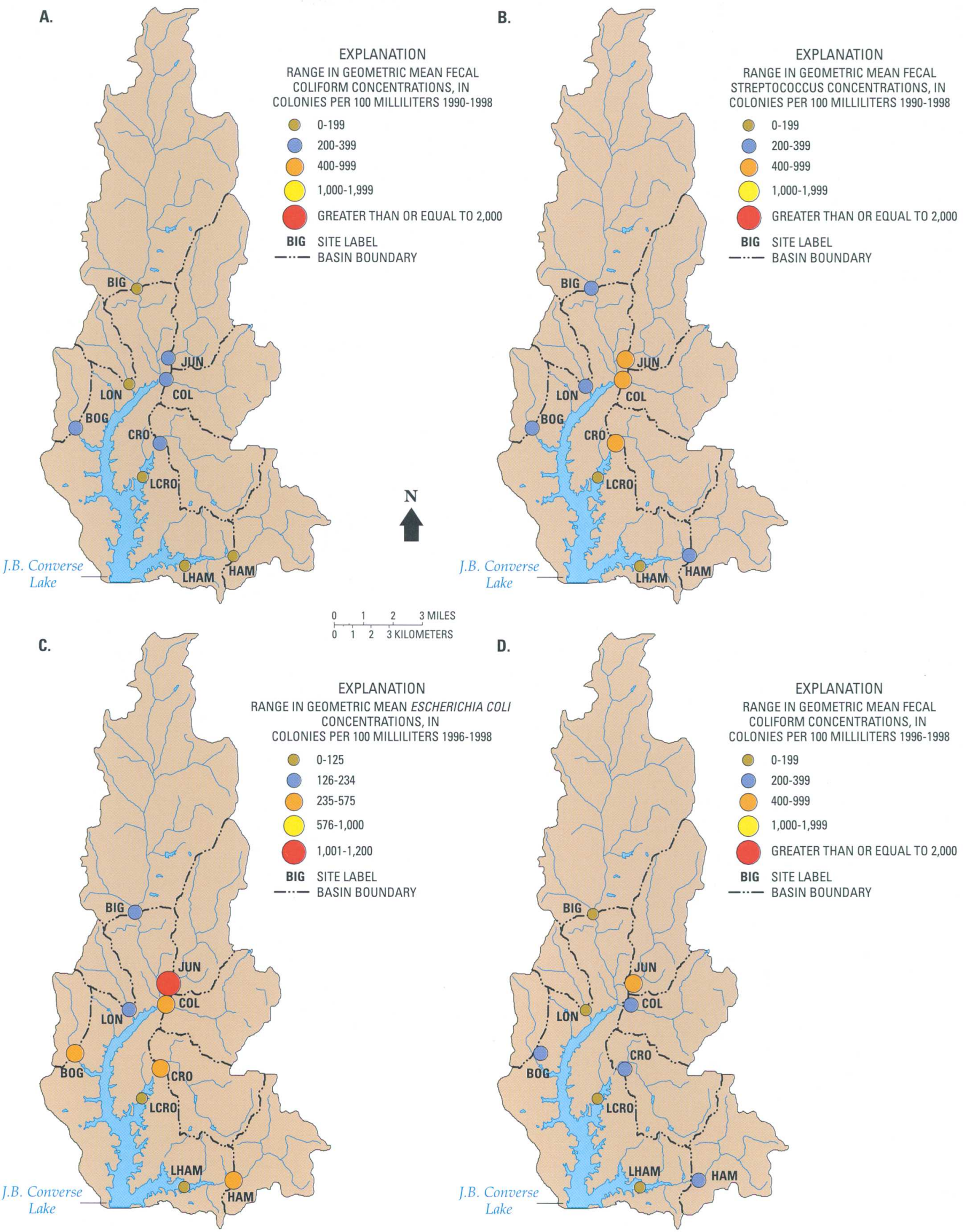

Figure 23. Ranges in geometric mean concentrations of fecal coliform and fecal streptococcus for 1990-98, and $E$. coli and fecal coliform for 1996-98. 
Table 21. Results of the seasonal Kendall tau test for trends in unadjusted and flow-adjusted bacterial concentrations at selected sites in the Converse Lake watershed, 1990-98

[Trends reported in units of colonies per 100 milliliters per year; bold values represent significant trends with $p$-value less than or equal to 0.05 ; -, not applicable]

\begin{tabular}{|c|c|c|c|c|c|c|}
\hline \multirow{2}{*}{ Fecal bacteria } & \multicolumn{3}{|c|}{ Unadjusted } & \multicolumn{3}{|c|}{ Adjusted } \\
\hline & Trend & tau value & $p$-value & Trend & tau value & $p$-value \\
\hline \multicolumn{7}{|c|}{ BIG CREEK (SITE BIG) } \\
\hline Fecal coliform & 8.25 & 0.27 & 0.090 & 6.075 & 0.11 & 0.5279 \\
\hline Fecal streptococcus & 15.17 & 0.16 & 0.3250 & 44.42 & 0.20 & 0.2332 \\
\hline \multicolumn{7}{|c|}{ JUNIPER CREEK (SITE JUN) } \\
\hline Fecal coliform & 76.67 & 0.40 & 0.0198 & 52.55 & 0.28 & 0.1150 \\
\hline Fecal streptococcus & 96.61 & 0.42 & 0.0161 & 82.15 & 0.42 & 0.0161 \\
\hline \multicolumn{7}{|c|}{ COLLINS CREEK (SITE COL) } \\
\hline Fecal coliform & 31.93 & 0.27 & 0.1319 & 19.95 & 0.18 & 0.3334 \\
\hline Fecal streptococcus & 64.50 & 0.23 & 0.2165 & -25.50 & -0.21 & 0.2530 \\
\hline \multicolumn{7}{|c|}{ LONG BRANCH (SITE LON) } \\
\hline Fecal coliform & 11.67 & 0.33 & 0.1198 & 8.371 & 0.22 & 0.3203 \\
\hline Fecal streptococcus & -2.067 & -0.08 & 0.7923 & 20.35 & 0.13 & 0.5808 \\
\hline \multicolumn{7}{|c|}{ BOGGY BRANCH (SITE BOG) } \\
\hline Fecal coliform & -8.071 & -0.07 & 0.8241 & -4.526 & -0.09 & 0.7404 \\
\hline Fecal streptococcus & -24.80 & -0.04 & 0.9121 & -45.12 & -0.17 & 0.4395 \\
\hline \multicolumn{7}{|c|}{ CROOKED CREEK (SITE CRO) } \\
\hline Fecal coliform & 10.00 & 0.14 & 0.4390 & 12.02 & 0.20 & 0.2509 \\
\hline Fecal streptococcus & 60.00 & 0.21 & 0.2068 & 46.00 & 0.18 & 0.2998 \\
\hline \multicolumn{7}{|c|}{ HAMILTON CREEK AT SNOW ROAD (SITE HAM) } \\
\hline Fecal coliform & 7.750 & 0.14 & 0.3989 & 9.150 & 0.14 & 0.3989 \\
\hline Fecal streptococcus & -15.83 & -0.15 & 0.3596 & -36.02 & -0.30 & 0.0583 \\
\hline \multicolumn{7}{|c|}{ HAMILTON CREEK AT PUMP STATION (SITE LHAM) } \\
\hline Fecal coliform & -0.7500 & -0.16 & 0.6203 & - & - & - \\
\hline Fecal streptococcus & -0.1667 & -0.20 & 0.5030 & - & - & - \\
\hline
\end{tabular}

Spearman rank correlation coefficients for median concentrations of each type of bacteria and the percentage of each type of land use were calculated to identify possible links between land use and fecal contamination. Scatter plots are useful to illustrate the relations between the percentages of various land-use types and the median concentrations of selected bacteria (fig. 24). No significant correlations between percentages of land-use types and median concentrations of bacteria were observed.

Protozoan monitoring detected very few encysted protozoans during the study period. Assay results from November 1990 through August 1992 are presented in the report by Journey and others (1995). Results from June 1993 to May 1998 are shown in appendix 3 and summarized here. In August 1993, one Giardia cyst was found during the Cryptosporidium assay of the site LHAM sample. The species of Giardia could not be determined from this assay, and no Giardia cysts were found during the Giardia lamblia assay. One Cryptosporidium oocyst was detected in the January 1996 sample from the holding reservoir at the filtration plant. In June 1996, six Giardia cysts and one Cryptosporidium oocyst were detected at Highway 98 , and six Giardia cysts were detected at site LHAM.

The low number of Giardia cyst and Cryptosporidium oocyst detections in the water samples makes it difficult to draw conclusions about actual concentrations of these pathogenic protozoans in the water supply or about factors that may influence 


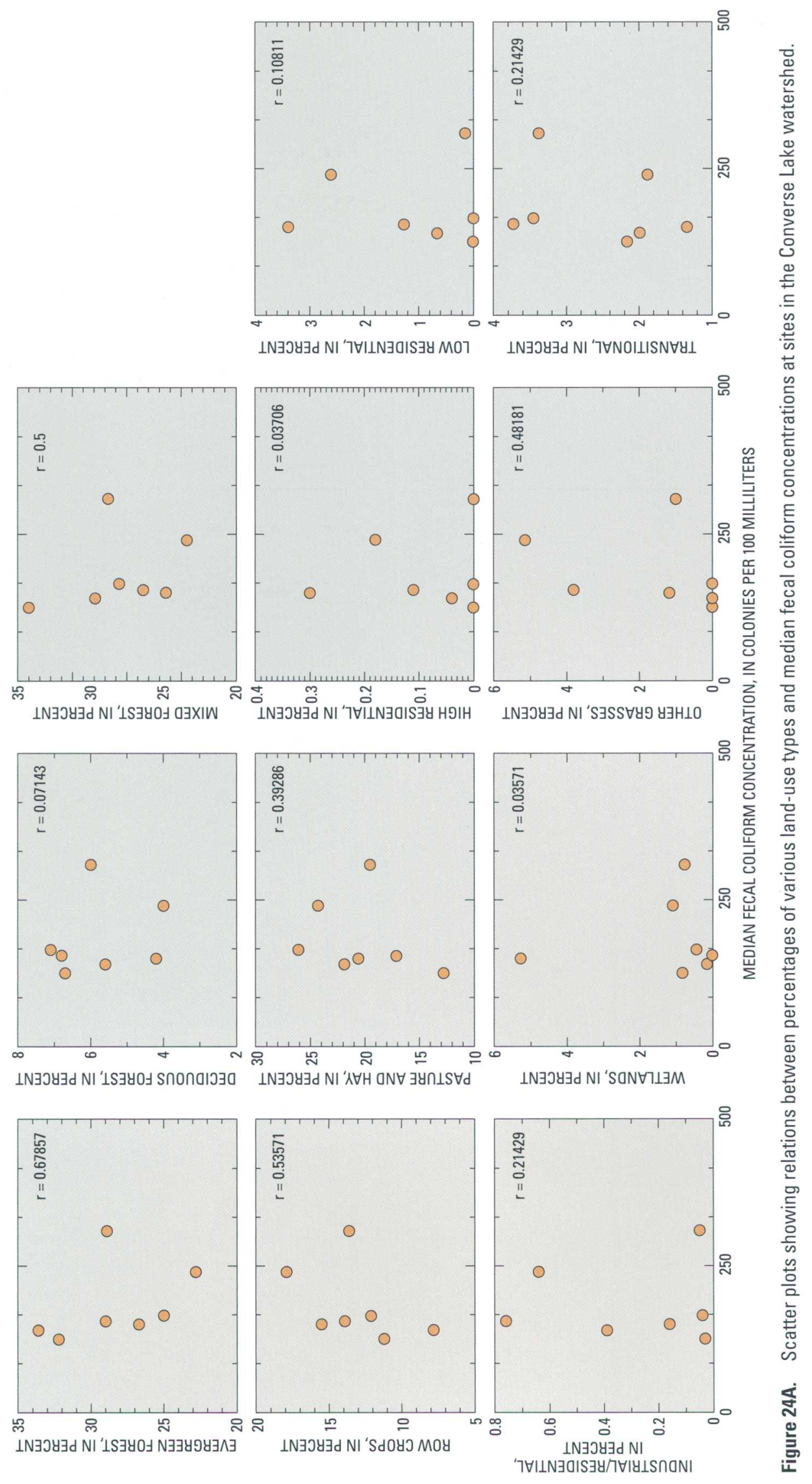




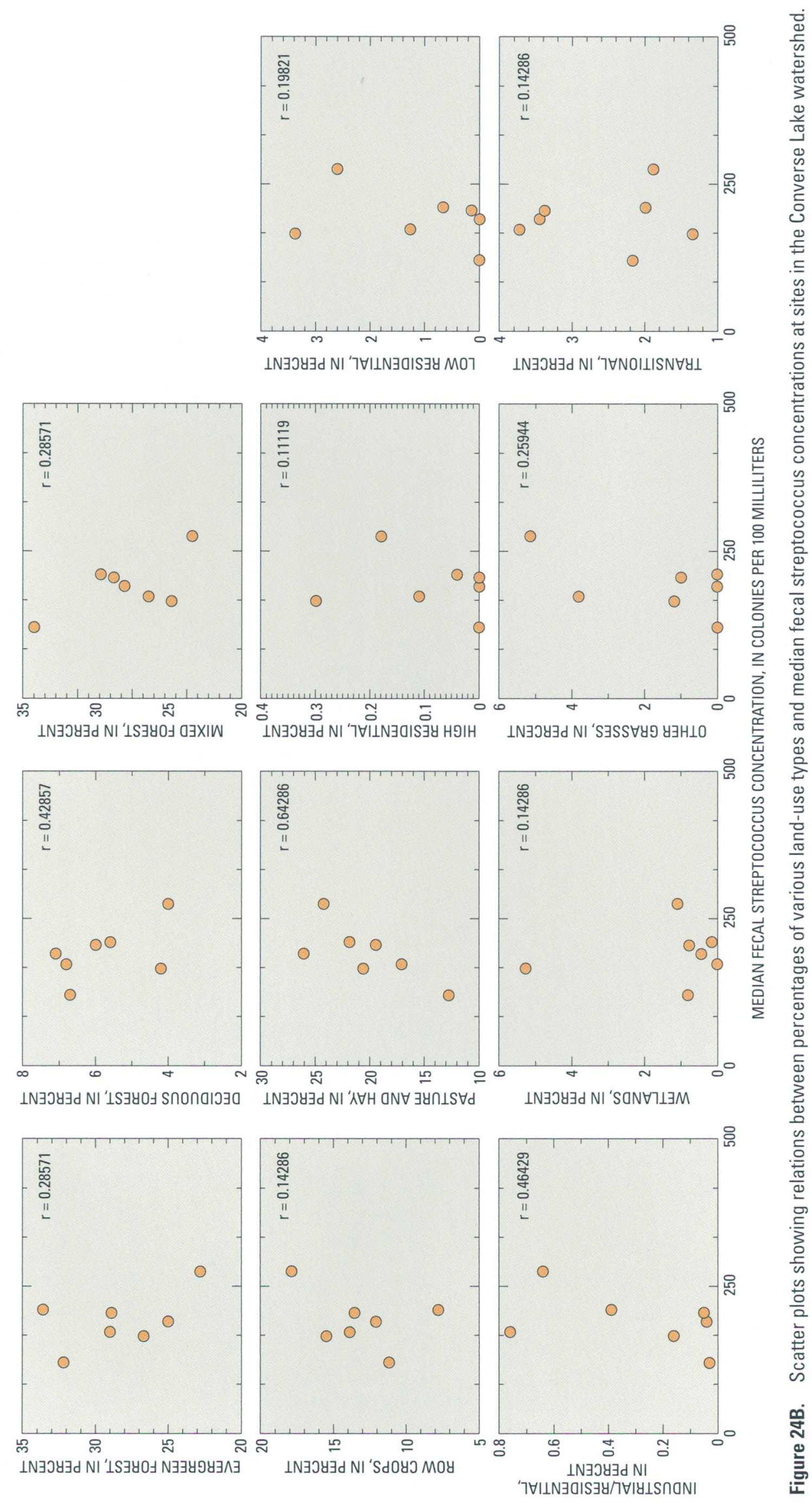




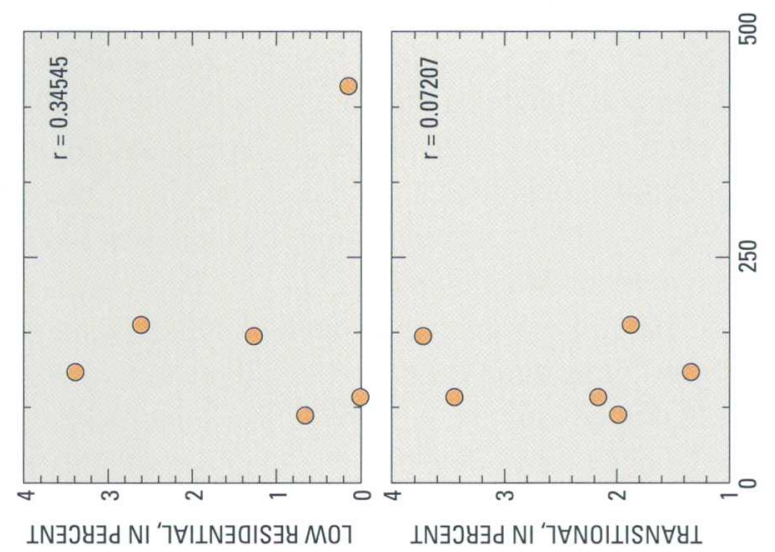

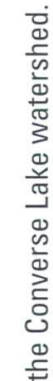
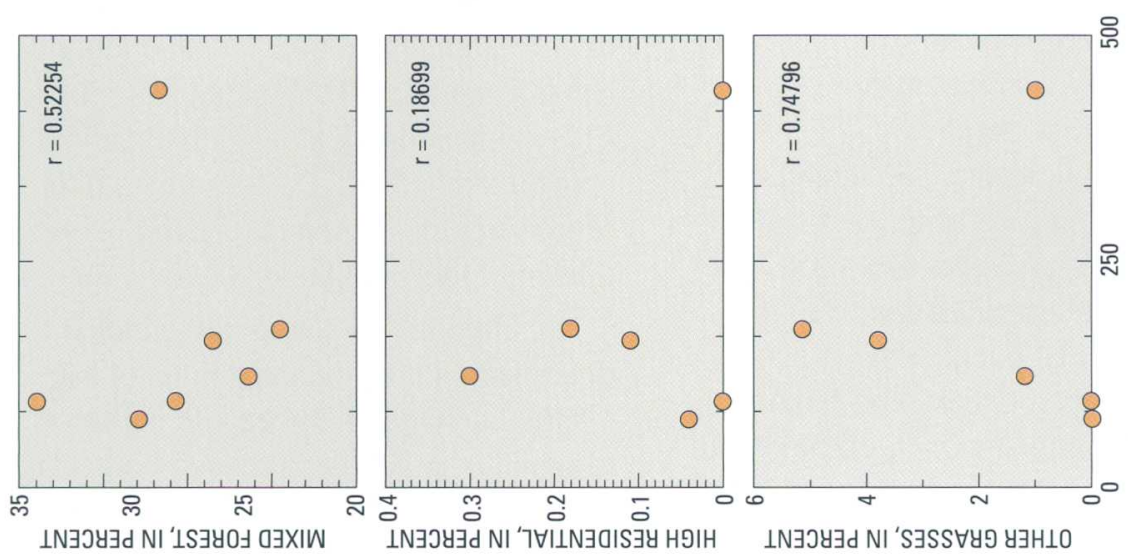

은

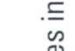
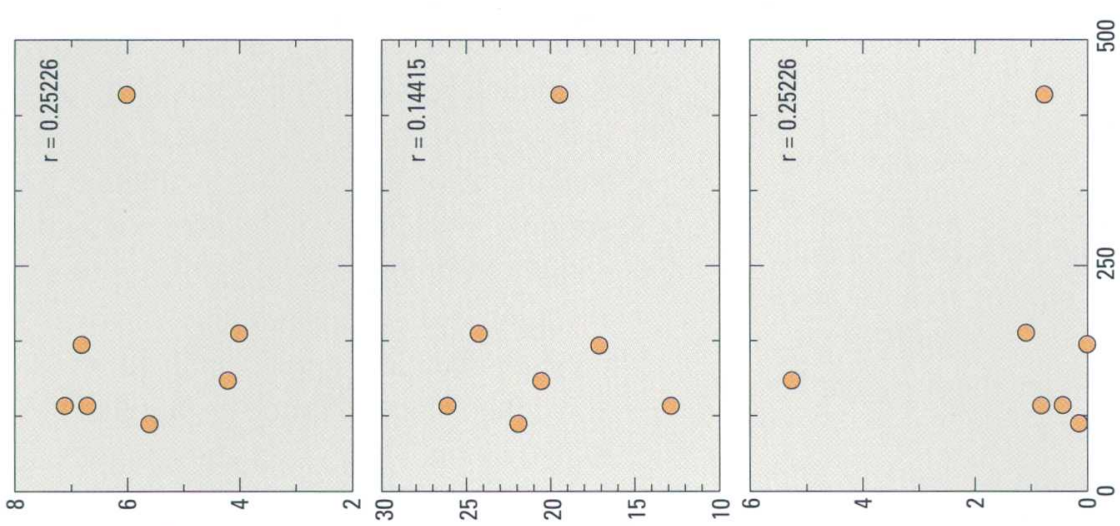

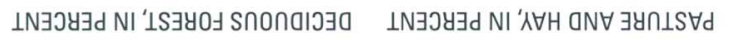

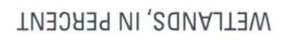
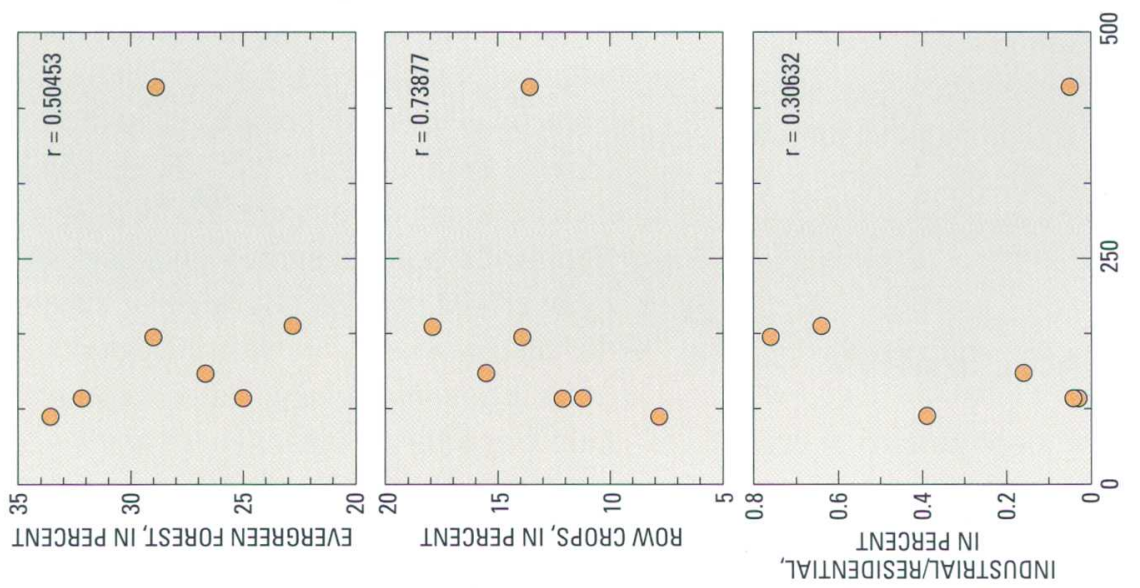

8

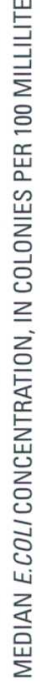

. 
these concentrations. Although concentrations of Giardia and Cryptosporidium seem to be small in the water supply, false negatives are possible with the sampling methods that were used. According to Rose (1990), "The interpretation of negative samples may be difficult and does not necessarily signify the absence of contaminating oocysts." More detections of Giardia and Cryptosporidium in Converse Lake occurred during spring and summer (May, June, and August) than during autumn and winter, suggesting a seasonality in the occurrence of cysts and oocysts. Continued monitoring of protozoan pathogen concentrations at the intake to the drinking-water system combined with bacteriological sampling may help define relations between concentrations of bacteria and pathogens in the watershed.

In summary, monitoring in the Converse Lake watershed for fecal contamination shows that some tributaries to Converse Lake have concentrations of fecal bacteria above existing criteria for whole-body contact uses. Concentrations of bacteria at lake sites LCRO (mouth of Crooked Creek) and LHAM (Hamilton Creek at pump station) were well below all criteria levels. Elevated concentrations of bacteria in the tributaries did not seem to cause elevated levels in the lake.

Juniper Creek (site JUN) had the highest geometric mean concentrations for all bacteria types during the study. Trend analyses show that flowadjusted concentrations of fecal streptococcus were increasing at site JUN during the 8 years of data collection. This apparent increasing trend in bacteria is cause for concern because the current (2001) bacteria levels in Juniper Creek are above the suggested criteria levels.

Detections of Giardia and Cryptosporidium were few at sites in the lake and the raw-water intake during the monitoring period. The low number of detections makes it difficult to draw any conclusions about actual cyst concentrations in the water supply. Most of the detections occurred during the summer months, but so few cysts were detected that it is not clear if there is a seasonal influence on cyst density.

\section{ORGANIC CARBON CHARACTERIZATION}

The naturally occurring organic carbon present in Converse Lake and its tributaries was characterized by estimating the reactivity and identifying the general source of the organic carbon. This characterization was based on past research of the factors that control the reactive nature and occurrence of organic matter in a watershed (Rook, 1977; de Leer and Erkelens, 1989; Amy and others, 1990; Miller and others, 1990; Reckhow and others, 1990; Nieminski and others, 1993; Krasner and others, 1994; Aiken and Cotsaris, 1995; Singer and others, 1995; Korshin and others, 1996; Summers and others, 1996). An understanding of the reactive nature and source of organic carbon is needed to minimize the formation of disinfection byproducts (DBPs), which are produced from a reaction between naturally occurring organic matter and chlorine when chlorine is added to water for disinfection. The DBPs of regulatory concern are trihalomethanes (THMs) and haloacetic acids (HAAs). This study addresses only THM formation-the sum of chloroform $\left(\mathrm{CHCl}_{3}\right)$, bromoform $\left(\mathrm{CHBr}_{3}\right)$, bromodichloromethane $\left(\mathrm{CHBrCl}_{2}\right)$, and dibromochloromethane $\left(\mathrm{CHBr}_{2} \mathrm{Cl}\right)$.

Organic matter in raw water is measured by determining the concentrations of total organic carbon (TOC) and dissolved organic carbon (DOC). TOC is the total of all organic carbon compounds, both dissolved and particulate, present in the raw water. DOC is the organic carbon that passes through a 0.45 micron filter and may include colloidal organic matter. Oxidants, including chlorine, chlorine dioxide, and monochloroamine, are added to raw water during water treatment for the purpose of disinfecting the water supply. In addition to disinfection, chlorine reacts by cleaving the aromatic rings of organic carbon compounds in the water and releasing halogenated byproducts that are a potential health risk. However, not all of the organic carbon compounds in organic matter have aromatic rings and, thus, may be less reactive and less a risk for THM formation.

Hydrology, soil type, and climate of the watershed affect the occurrence of naturally occurring reactive organic matter which, in turn, influences the occurrence of DBP precursors in the water supply (Aiken and Cotsaris, 1995). Hydrologic processes include transport of terrestrially derived, tannin- and lignin-rich organic carbon into a stream, river, or lake by overland flow and flushing of the shallow soil zone during rain events. Terrestrially derived (allochthonous) organic carbon compounds include humic and fulvic acids. These acids generally constitute about 50 to 60 percent of the dissolved organic carbon found in river and lake waters; these acids also have a high reactivity with chlorine (de Leer 
and Erkelens, 1989). Algal growth and microbial processes occur within the aquatic environment (autochthonous) and produce organic carbon compounds, such as carbohydrates, pigments, proteins, lipids, polysaccharides, and amino acids, which are not as reactive with chlorine (de Leer and Erkelens, 1989). Algal and microbial processes can dominate in slower moving waters, such as reservoirs. Ground-water discharge is a negligible source of organic carbon because concentrations generally are low.

Soils can influence the transport of organic carbon to streams or lakes. Iron-rich lateritic soils tend to adsorb the organic carbon in the deeper soil layers causing the organic carbon to slowly leach into the stream. Sandy soils do not hold or sorb the organic carbon as readily, thus allowing for quick flushing during rain events.

The tendency of naturally occurring organic carbon to react with chlorine is a function of several factors (Aiken and Cotsaris, 1995). Source, geochemistry, and degradation by microbial processes influence the reactivity of the organic carbon. Research on organic geochemistry of naturally occurring organic matter has shown that the ability of the organic carbon to react with chlorine depends, in part, on the aromaticity (the number of aromatic rings present in the organic matter) and the carbon-to-nitrogen ratio in the organic carbon (table 22). In general, terrestrial, lignin-rich vegetation (such as trees) has a higher carbon content and, consequently, higher carbon-tonitrogen ratios than aquatic vegetation (such as emergent wetland plants); therefore, organic matter that is derived from terrestrial sources tends to react more readily with chlorine to form DBPs than organic matter from aquatic sources.

Absorption of light by natural waters provides a semiqualitative indicator of the concentration of naturally occurring organic matter in the water, especially ultraviolet light absorbance at 254 nanometer wavelength (Korshin and others, 1997). Most organic matter molecules that absorb light at ultraviolet ranges are aromatic groups, including phenols and aromatic acids (found in high concentrations in humic and fulvic acids). Previous studies have shown a good correlation between ultraviolet light absorbance at 254 nanometers and trihalomethane-formation potential (Reckhow and others, 1990).

\section{Organic Carbon Analysis Methods and Approach}

Sampling water for organic carbon, which may be precursors to disinfection by-products, consisted of collecting monthly surface-water samples over an 18-month period at seven tributary sites and two lake

Table 22. General geochemical characteristics of naturally occurring organic carbon compounds in surface water derived from lignin-derived (allochthonous) or microbial/algal-derived (autochthonous) sources (modified from Aiken and Cotsaris, 1995)

\begin{tabular}{ll}
\hline \multicolumn{1}{c}{$\begin{array}{c}\text { Source of naturally occurring organic matter in rivers and lakes } \\
\text { Lignin-derived } \\
\text { (allochthonous) }\end{array}$} & \multicolumn{1}{c}{$\begin{array}{c}\text { Microbial/algal-derived } \\
\text { (autochthonous) }\end{array}$} \\
\hline Low in nitrogen & High in nitrogen \\
High in aromatic carbon; low in aliphatic carbon & Low in aromatic carbon; high in aliphatic carbon \\
High phenolic content & Low phenolic content \\
Greater absorbance of ultraviolet light at 254 nanometers & Less absorbance of ultraviolet light at 254 nanometers \\
More reactive & Less reactive \\
\hline
\end{tabular}


sites in the Converse Lake watershed (table 23). Samples were analyzed for TOC, DOC, tannin and lignin, and chlorophyll $a$ and $b$ concentrations (site LHAM only) at the USGS Laboratory in Ocala, Florida. Field blanks of organic-free water were processed for TOC, DOC, and tannin and lignin following the same quality assurance and quality control procedures used for surface-water samples. Streamflow, water temperature, dissolved oxygen (concentration and percent saturation), $\mathrm{pH}$, alkalinity, Secchi disk depth (at lake sites), and specific conductance were measured in the field at the time of sampling.

Table 23. Types and potential sources of organic carbon in surface-water samples collected in the Converse Lake watershed

\begin{tabular}{|c|c|}
\hline Samples measured & Potential sources \\
\hline $\begin{array}{l}\text { Total and dissolved organic } \\
\text { carbon }\end{array}$ & $\begin{array}{l}\text { Concentrations of all organic } \\
\text { carbon compounds }\end{array}$ \\
\hline Tannin and lignin & $\begin{array}{l}\text { Estimate of the amount of } \\
\text { organic carbon compounds } \\
\text { derived from terrestrial plant } \\
\text { material (humics) }\end{array}$ \\
\hline Chlorophyll $a, b$ & $\begin{array}{l}\text { Estimate of the amount of algae } \\
\text { in water }\end{array}$ \\
\hline $\begin{array}{l}\text { Ultraviolet absorbance at } \\
254 \text { nanometers }\end{array}$ & $\begin{array}{l}\text { Estimate of the reactivity of the } \\
\text { organic carbon }\end{array}$ \\
\hline $\begin{array}{l}\text { Trihalomethane-formation } \\
\text { potential }\end{array}$ & $\begin{array}{l}\text { Measure of the amount of } \\
\text { trihalomethanes formed as a } \\
\text { result of chlorination }\end{array}$ \\
\hline Trihalomethane yield & $\begin{array}{l}\text { Measure of the amount of } \\
\text { trihalomethanes formed per } \\
\text { unit of organic carbon }\end{array}$ \\
\hline $\begin{array}{l}\text { Specific absorbance (ultra- } \\
\text { violet absorbance/ } \\
\text { dissolved organic carbon) }\end{array}$ & $\begin{array}{l}\text { Estimate of the humic content of } \\
\text { the dissolved organic carbon }\end{array}$ \\
\hline
\end{tabular}

Quarterly surface-water samples were collected at the three continuous-record stations and at the one lake site at the pumping station, and were analyzed for trihalomethane-formation potential (THM-FP) at the USGS National Water Quality Laboratory in Denver, Colorado. Surface-water samples were analyzed according to Standard Method 5710 by purge and trap gas chromatography/mass spectroscopy and by solidphase microextraction for THMs (Symons and others, 1981; Greenberg and others, 1992a). Filtered and unfiltered water samples were analyzed for ultraviolet absorbance at 254 nanometers (UVA) at the USGS Alabama District Office using a Bucks Scientific CE
2041 ultraviolet-visible spectrum (UV-Vis)

spectrophotometer and a 4-cell changer that contained quartz cells with $1-\mathrm{cm}$ pathlength. The filtered sample data represented the reactivity of DOC; the unfiltered samples represented the reactivity of TOC. Each sample was analyzed in triplicate, and the UVA results were averaged to obtain the final results for the filtered (UVA-DOC) and unfiltered (UVA-TOC) samples, which had units of absorbance per centimeter ${ }^{-1}\left(\mathrm{~cm}^{-1}\right)$. Laboratory blanks of organic-free water were analyzed in all cells before and after sample analysis for quality assurance and quality control. Specific ultraviolet absorbance (SUVA) was determined as the ratio of ultraviolet absorbance to DOC concentration in units of liters per milligram per centimeter.

Characterizing the origin of the reactive organic carbon at each tributary and lake site involved several interpretive approaches, including statistical, graphical, and spatial analyses of the data. The results were used to evaluate the reactivity of the organic carbon and the relation of sources and spatial distribution of the reactive organic carbon to land use in the watershed. Statistical summaries of these data are presented in appendix 1 . The tendency of the organic carbon at each site to react with chlorine to form disinfection byproducts was estimated by the UVA of the water sample at that site. Trihalomethane-formation potential was compared to UVA levels for verification of the UVAestimated reactivity of the organic carbon. Seasonal variability of reactive organic carbon in the lake and its tributaries was determined. Spearman rho correlation coefficients (previously described) were determined for the total and dissolved organic carbon concentrations, tannin and lignin (terrestrial plant material) concentrations, Secchi disk depth, and chlorophyll (aquatic plant material) concentrations to identify a probable source of the organic carbon (table 23). The spatial distribution of median TOC, DOC, tannin and lignin, and UVA levels were determined to identify the subbasin(s) contributing the greatest amount of reactive organic carbon to the lake.

\section{Results of Organic Carbon Analysis}

The USEPA set a maximum contaminant level (MCL), effective in 1999, of $80 \mu \mathrm{g} / \mathrm{L}$ for total THMs in finished water (U.S. Environmental Protection Agency, 1998), a reduction from the previous MCL of $100 \mu \mathrm{g} / \mathrm{L}$. The MAWSS submitted quarterly monitoring information to the USEPA on the formation of THM in 
treated water samples collected from July 1997 to June 1988, as mandated in the ICR of the Safe Drinking Water Act (U.S. Environmental Protection Agency, 1996a,b,c). Municipal surface-water supply systems in Birmingham, Tuscaloosa, and Huntsville, Alabama, also submitted quarterly THM information. During the monitored period, the treated water from the MAWSS (Mobile) and Birmingham exceeded the $80-\mu \mathrm{g} / \mathrm{L} \mathrm{MCL}$ during the summer and fall (fig. 25; U.S.

Environmental Protection Agency, 2000). The results of the monitoring indicated that the greatest mean THM concentration was in treated water from the
MAWSS $(76 \mu \mathrm{g} / \mathrm{L})$, followed by mean THM concentrations in treated water for Birmingham $(67 \mu \mathrm{g} / \mathrm{L})$, Tuscaloosa $(54 \mu \mathrm{g} / \mathrm{L})$, and Huntsville $(46 \mu \mathrm{g} / \mathrm{L})$. These mean THM concentrations are similar to those reported for municipal water supplies in North Carolina (Singer and others, 1995), but are lower than levels reported in Ohio and Florida (Summers and others, 1996; fig. 26). Nieminski and others (1993) reported a range of 1 to $97 \mu \mathrm{g} / \mathrm{L}$ of THM concentrations in treated water from 35 water-supply utilities in Utah.

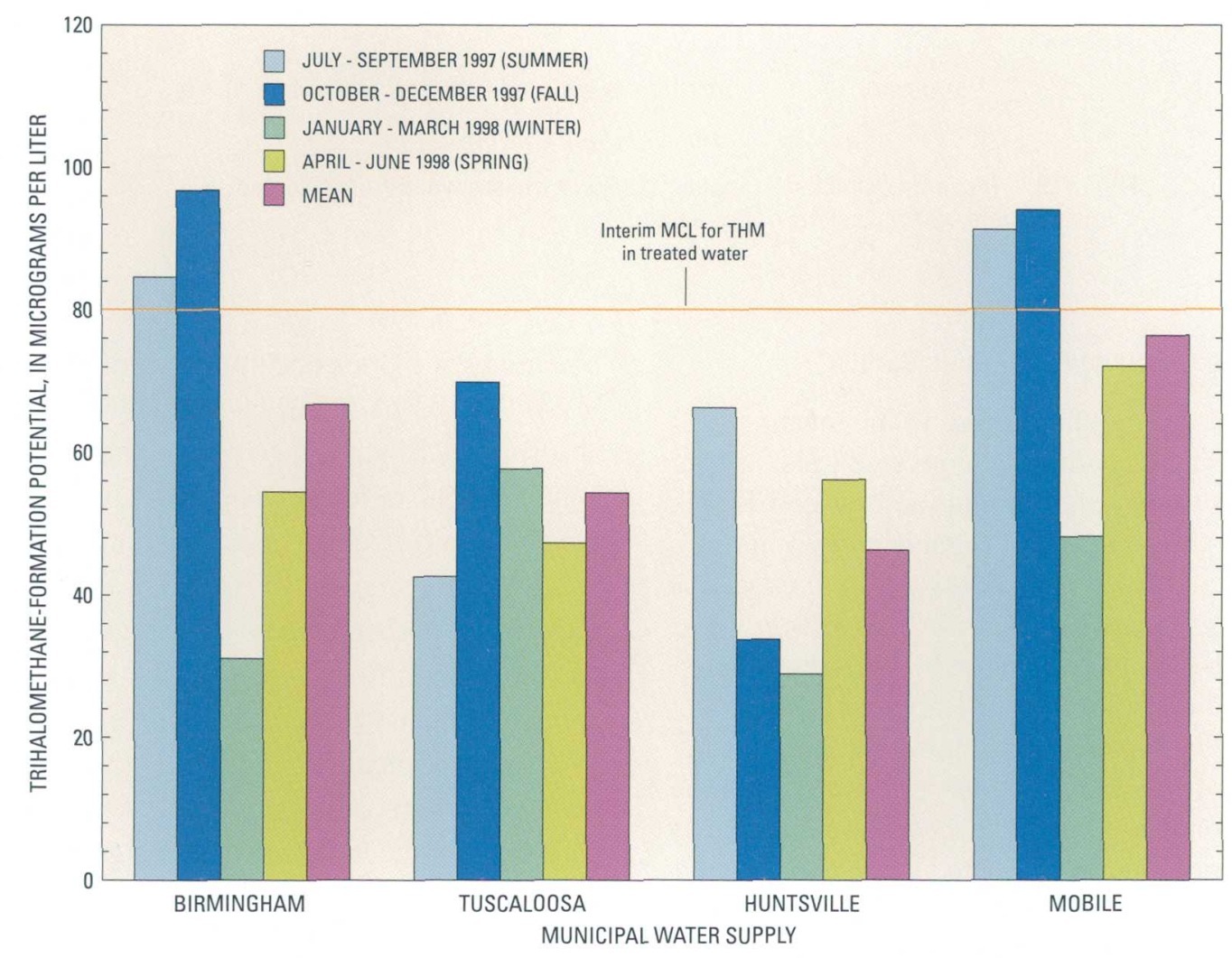

Figure 25. Quarterly and mean results of monitoring for trihalomethane concentrations in treated water at four municipal water supplies in Alabama as part of the Information Collection Rule requirements. 


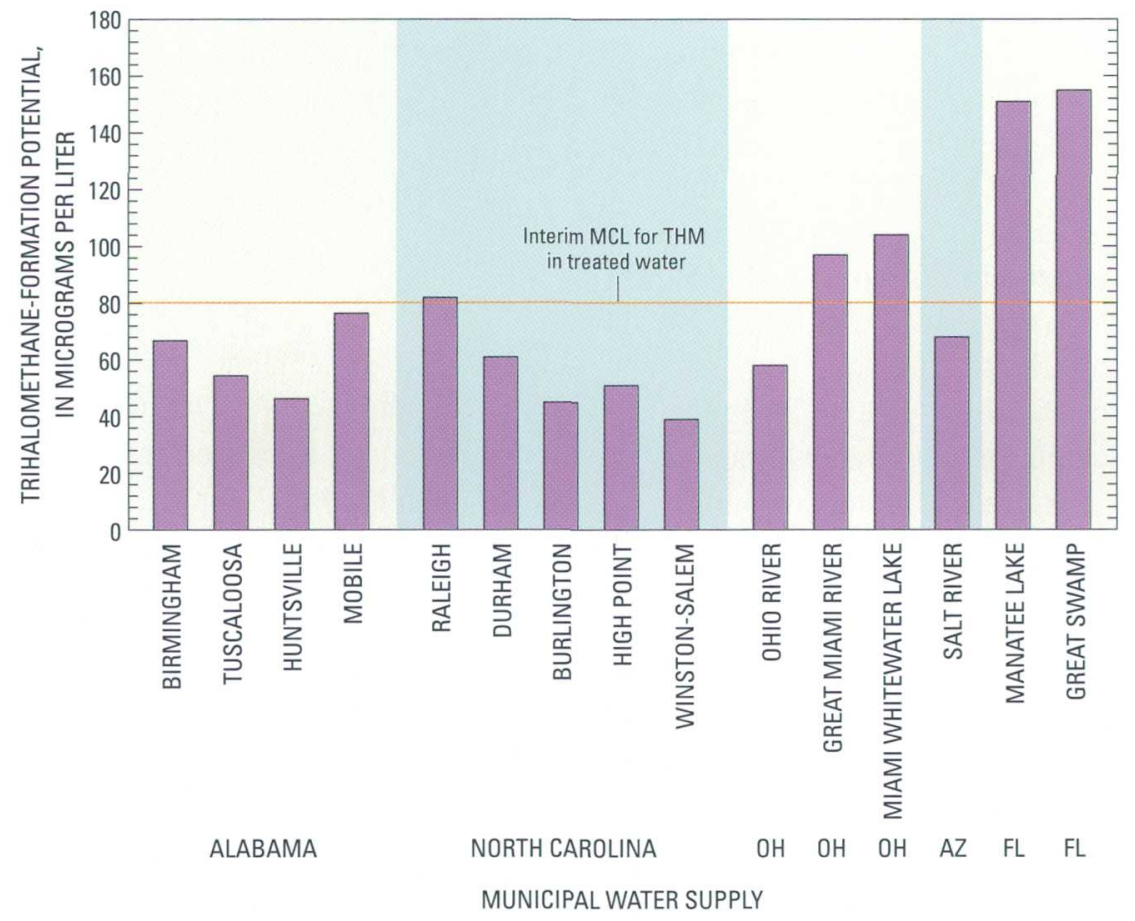

Figure 26. Mean trihalomethane concentrations in treated water from selected municipal water supplies in the United States.

\section{Estimation of Reactivity of the Organic Carbon}

The first step in understanding the reactive nature of the organic carbon in Converse Lake and its tributaries was to identify the relation between THM formation and the presence of organic carbon in the water. If TOC and DOC were consistently of a reactive nature, a strong, statistically significant relation between THM-FP and organic carbon concentrations could be expected. The reactive fraction of TOC and DOC in the lake and tributaries, however, could vary with season or flow; thus, a better indication might be the aromatic content of the organic carbon estimated by UVA or algal production estimated by chlorophyll. In this study, the relation between THM-FP and UVA was stronger and statistically more significant than the relation between THM-FP and TOC or DOC.

When water samples were collected for THM-FP analyses, concurrent water samples were analyzed for potential surrogate concentrations of TOC, DOC, UVA-TOC, UVA-DOC, tannin and lignin, and specific absorbance, which is a computed value of the UVADOC to DOC ratio. The degree of correlation among the potential surrogate concentrations (sampled monthly at all sites) and THM-FP (sampled quarterly at four sites) was determined by using Spearman rho correlation coefficients. This statistical analysis was applied to the data to establish the best surrogate for THM-FP, which allowed monthly extrapolation of the reactive carbon data. The results of the statistical correlation indicated statistically significant relations between THM-FP and UVA-TOC, UVA-DOC, and tannin and lignin ( $p$-value $<0.05$; fig. 27$)$, with UVATOC having the strongest correlation (0.7021). Therefore, UVA was selected to be the surrogate measure of the reactive carbon in a sample. 
EXPLANATION

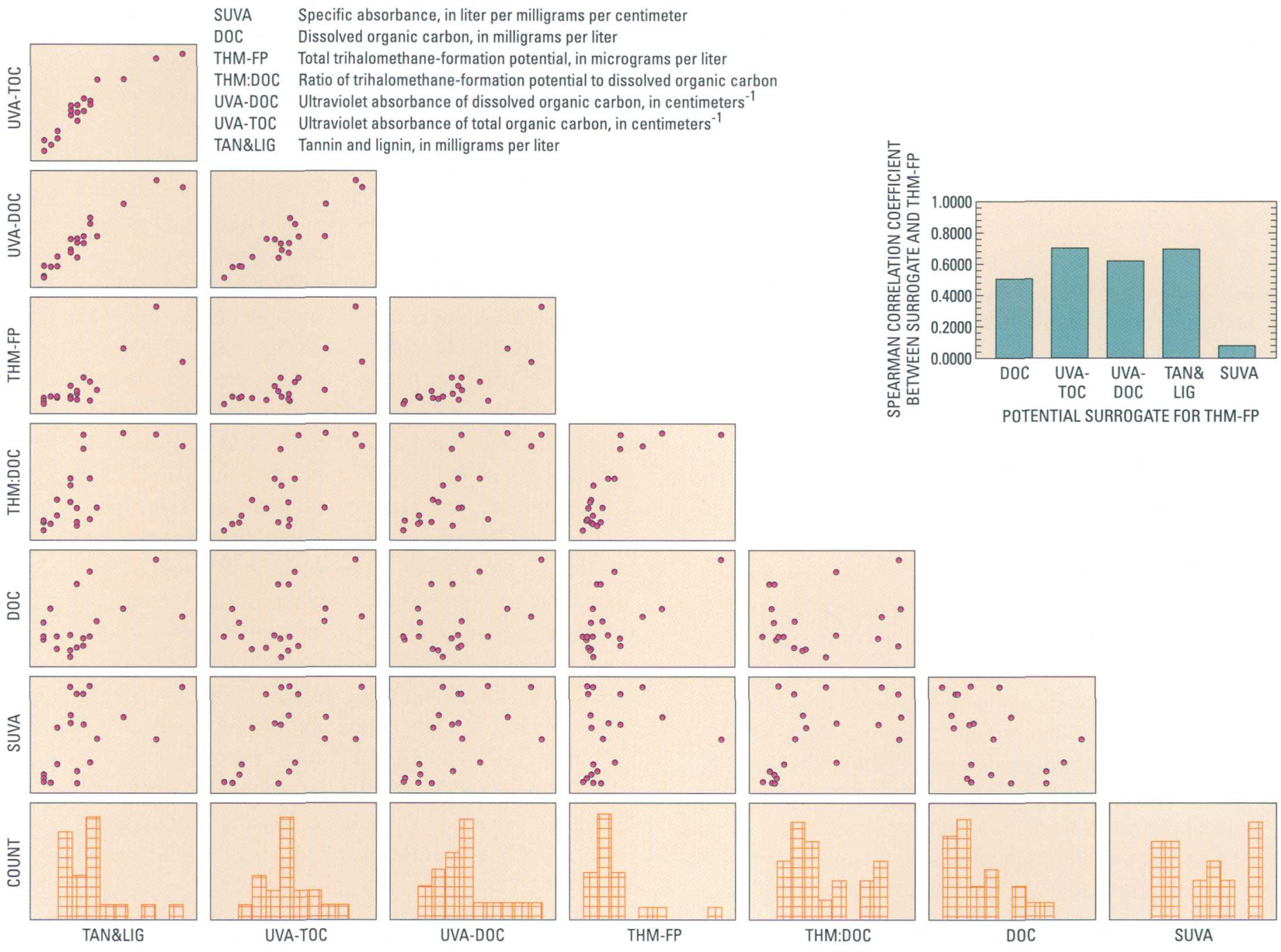

Figure 27. Correlation coefficients and scatter plots of trihalomethane-formation potential and potential surrogate concentrations in the Converse Lake watershed, 1996-98. 


\section{Spatial and Temporal Distribution}

The degree of spatial and temporal variability of TOC, DOC, tannin and lignin, UVA, specific absorbance, and THM-FP levels was determined, and differences over time and among subbasins were assessed. A combination of graphical and statistical techniques was used, and GIS coverages were developed to better evaluate spatial distribution and temporal variability of reactive organic carbon. The amount of organic carbon in the water from tributary sites varied to some degree from subbasin to subbasin and over time during the study period (October 1996 to June 1998). In general, the lake sites had intermediate organic carbon levels that were more constant spatially and temporally than the tributary sites.

Organic carbon contributions from the tributaries to the lake were evaluated. Median DOC and TOC concentrations were lowest in Crooked Creek, Long Branch, and Hamilton Creek and highest in Boggy Branch and Big Creek (appendix 1; figs. 28, 29). The greatest range in concentrations in DOC and TOC concentrations was observed in Juniper Creek; the smallest range in concentrations was observed at the lake sites (fig. 28). The dissolved fraction of the organic carbon generally accounted for more than 90 percent of the total organic carbon at all sites.

Tannin and lignin were used to estimate the terrestrial-source component of the organic carbon. Median tannin and lignin concentrations displayed a similar spatial pattern as the organic carbon, with the lowest median value found in Crooked Creek $(0.5 \mathrm{mg} / \mathrm{L})$ and the highest found in Big Creek $(1 \mathrm{mg} / \mathrm{L})$ (figs. 28, 29). The greatest interquartile range in concentrations in tannin and lignin concentrations was identified in Juniper Creek; the least, at the lake sites (fig. 28). Tannin and lignin generally accounted for about 22 percent of the dissolved organic carbon found in water from the tributary sites, and 18 and 15 percent at the lake sites at the mouth of Crooked Creek and at the pump station (sites LCRO and LHAM, respectively).

Median UVA values for water collected at tributary sites ranged from 0.165 (Crooked Creek) to $0.256 \mathrm{~cm}^{-1}$ (Boggy Branch) for unfiltered TOC samples (figs. 29, 30), and from 0.122 (Crooked Creek) to $0.204 \mathrm{~cm}^{-1}$ (Boggy Branch) for filtered, DOC samples (fig. 30). Median UVA values at the lake sites were intermediate to the range of values for Boggy Branch and Crooked Creek, and had less variability. Median UVA values for TOC samples at the lake sites were $0.168 \mathrm{~cm}^{-1}$ for the mouth of Crooked Creek (site LCRO) and $0.158 \mathrm{~cm}^{-1}$ for the pump station at the mouth of Hamilton Creek (site LHAM). Median UVA values for DOC samples at sites LCRO and LHAM were 0.151 and $0.145 \mathrm{~cm}^{-1}$, respectively. The UVA values for the DOC samples were normalized for the amount of dissolved organic carbon that was present by computing the specific ultraviolet absorbance (SUVA). Examination of the median SUVA values identified a different pattern. The highest median SUVA values were at the Crooked (site CRO) and Hamilton (site HAM) Creek sites $\left(0.062\right.$ and $0.060 \mathrm{~cm}^{-1} / \mathrm{mg} / \mathrm{L}$, respectively); the lowest median SUVA value was at the lake site (LHAM) at the pump station $\left(0.032 \mathrm{~cm}^{-1} / \mathrm{mg} / \mathrm{L}\right)$ (fig. 30 ). This suggests that the DOC in Crooked and Hamilton Creeks may be more reactive than at the other sites; and that the DOC in the lake is less reactive.

Results of the THM-FP analyses identified the highest THM-FP concentrations were in water from 

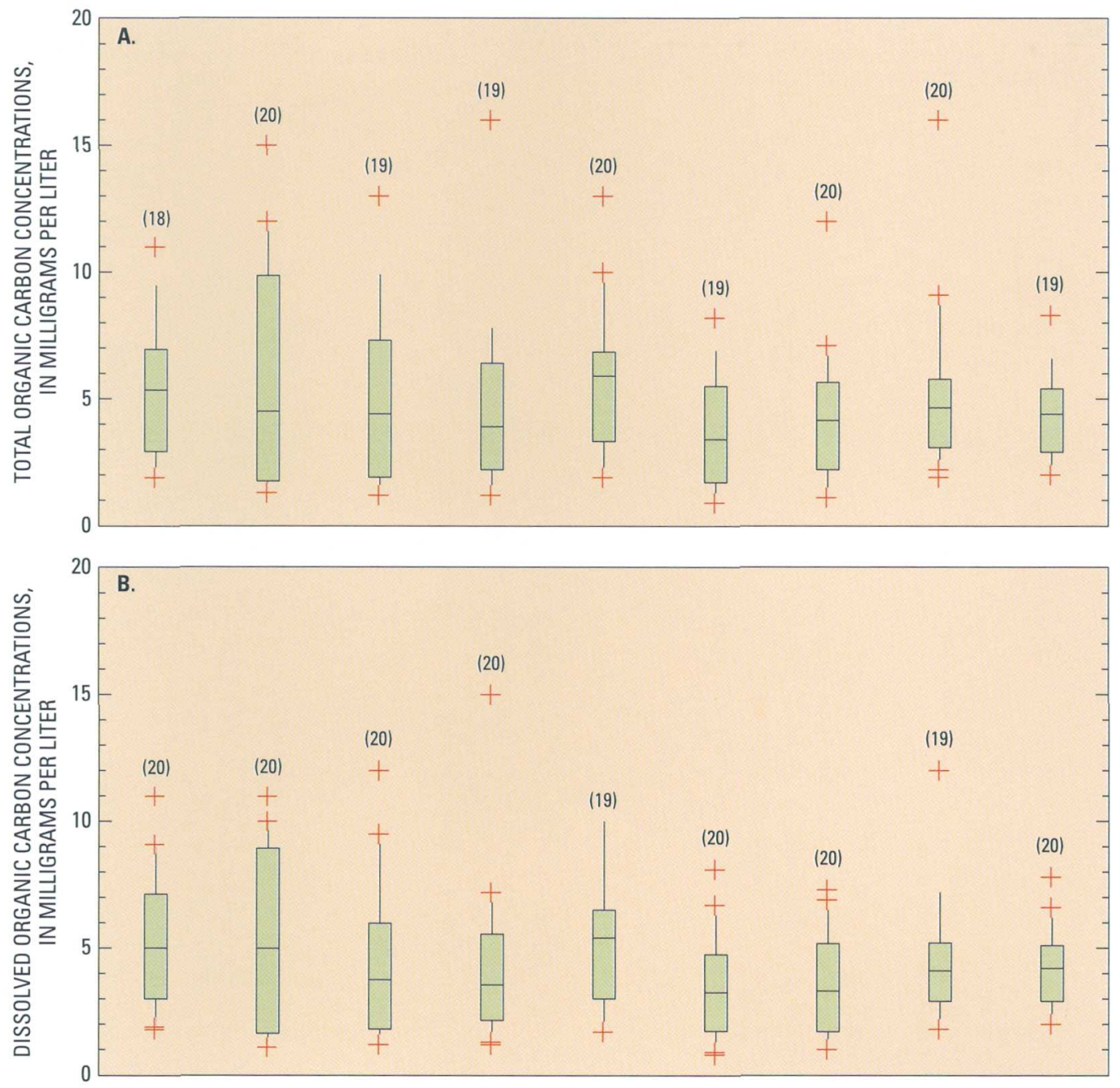

\section{EXPLANATION}

(19) NUMBER OF OBSERVATIONS

$+\quad$ DATA VAlues OUTSIDE THE $10^{\text {th }}$ AND $90^{\text {th }}$ PERCENTILE $90^{\text {th }}$ PERCENTILE $75^{\text {th }}$ PERCENTILE MEDIAN $25^{\text {th }}$ PERCENTILE $10^{\text {th }}$ PERCENTILE

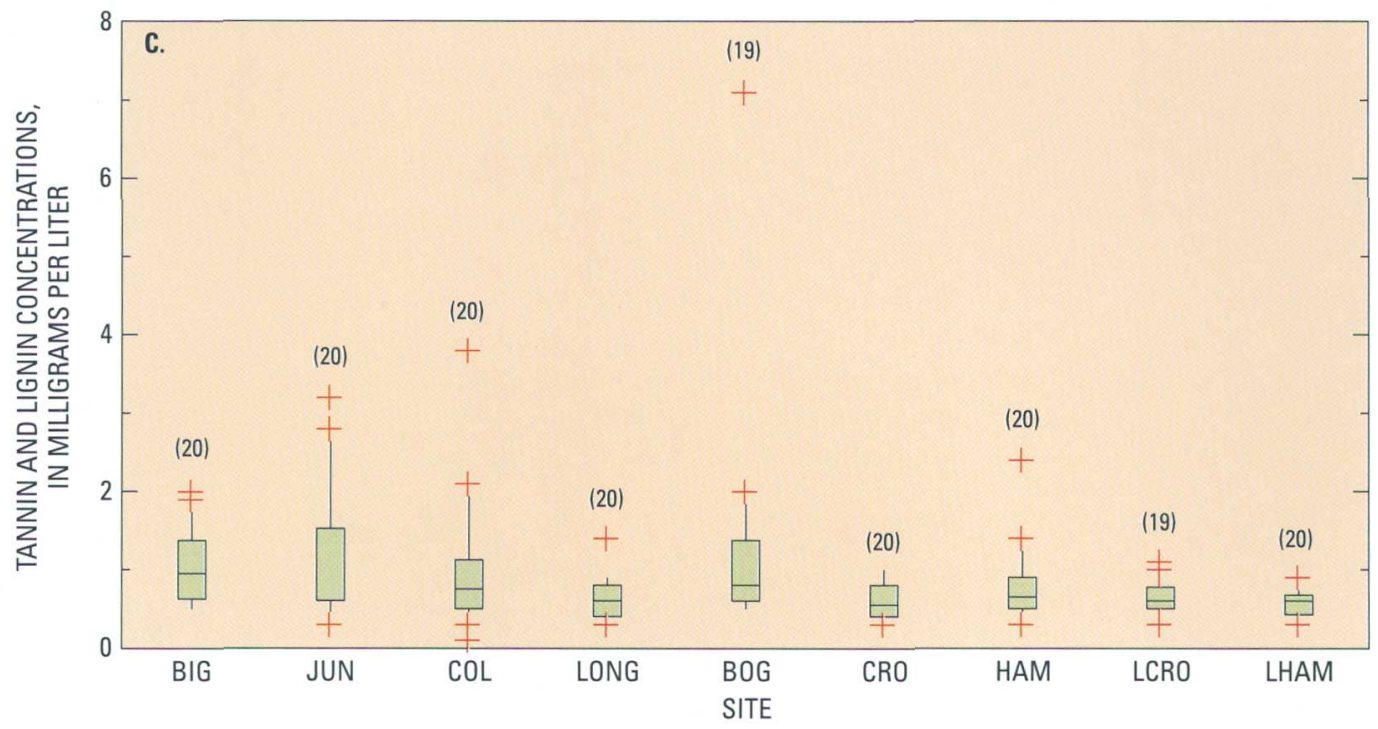

Figure 28. Boxplots of total organic carbon, dissolved organic carbon, and tannin and lignin concentrations at selected sites in the Converse Lake watershed, 1996-98. 

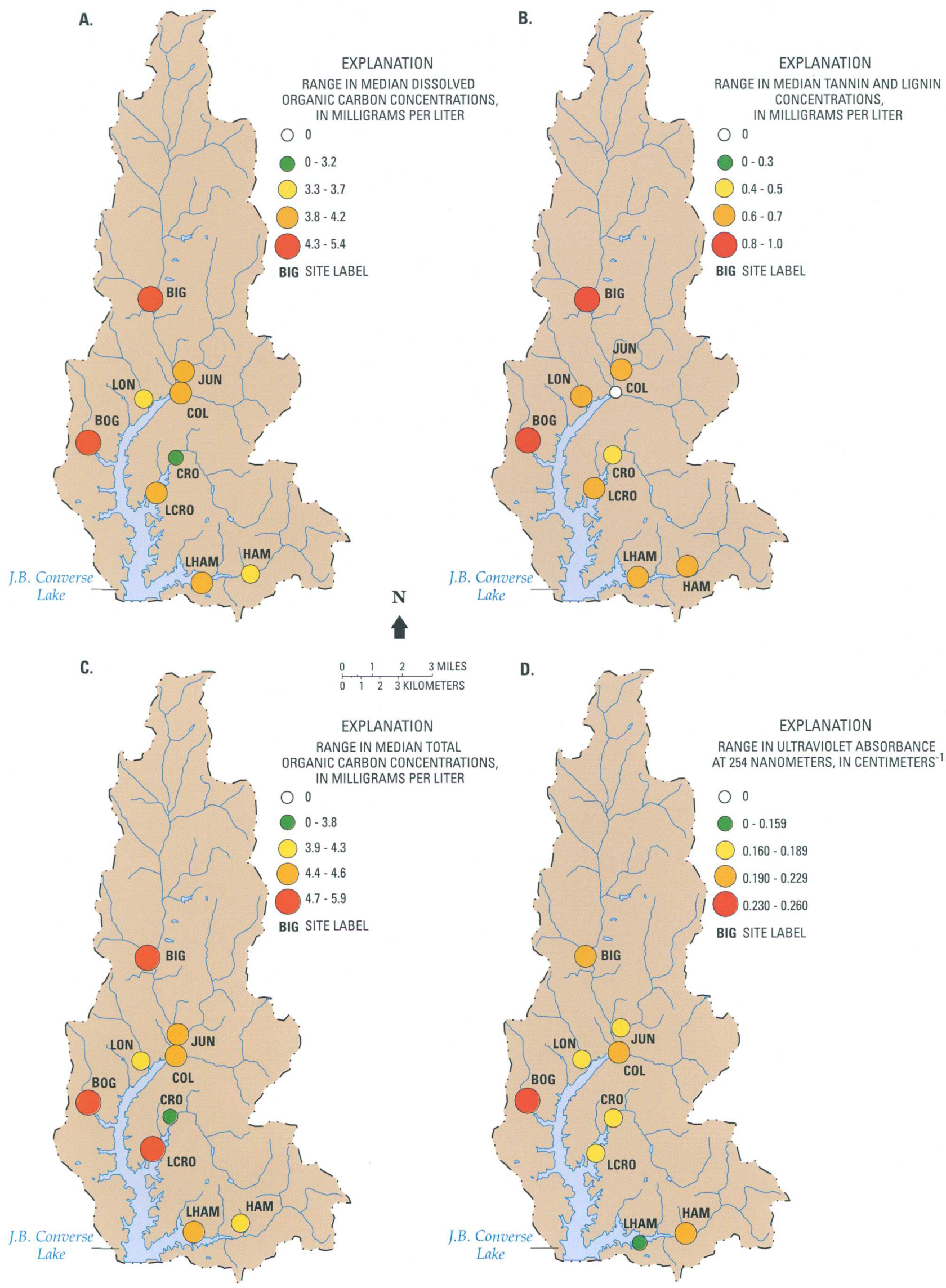

D.

\section{TETRATIONS,}

LITER
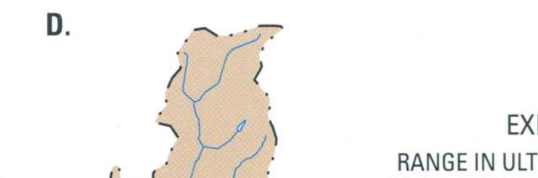

EXPLANATION

RANGE IN ULTRAVIOLET ABSORBANCE AT 254 NANOMETERS, IN CENTIMETERS ${ }^{-1}$

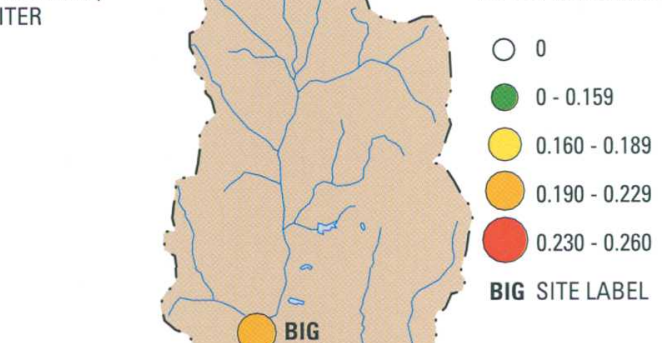

Figure 29. Range in median concentrations of dissolved organic carbon, tannin and lignin, total organic carbon, and ultraviolet absorbance at 254 nanometers in the Converse Lake watershed, 1996-98. 


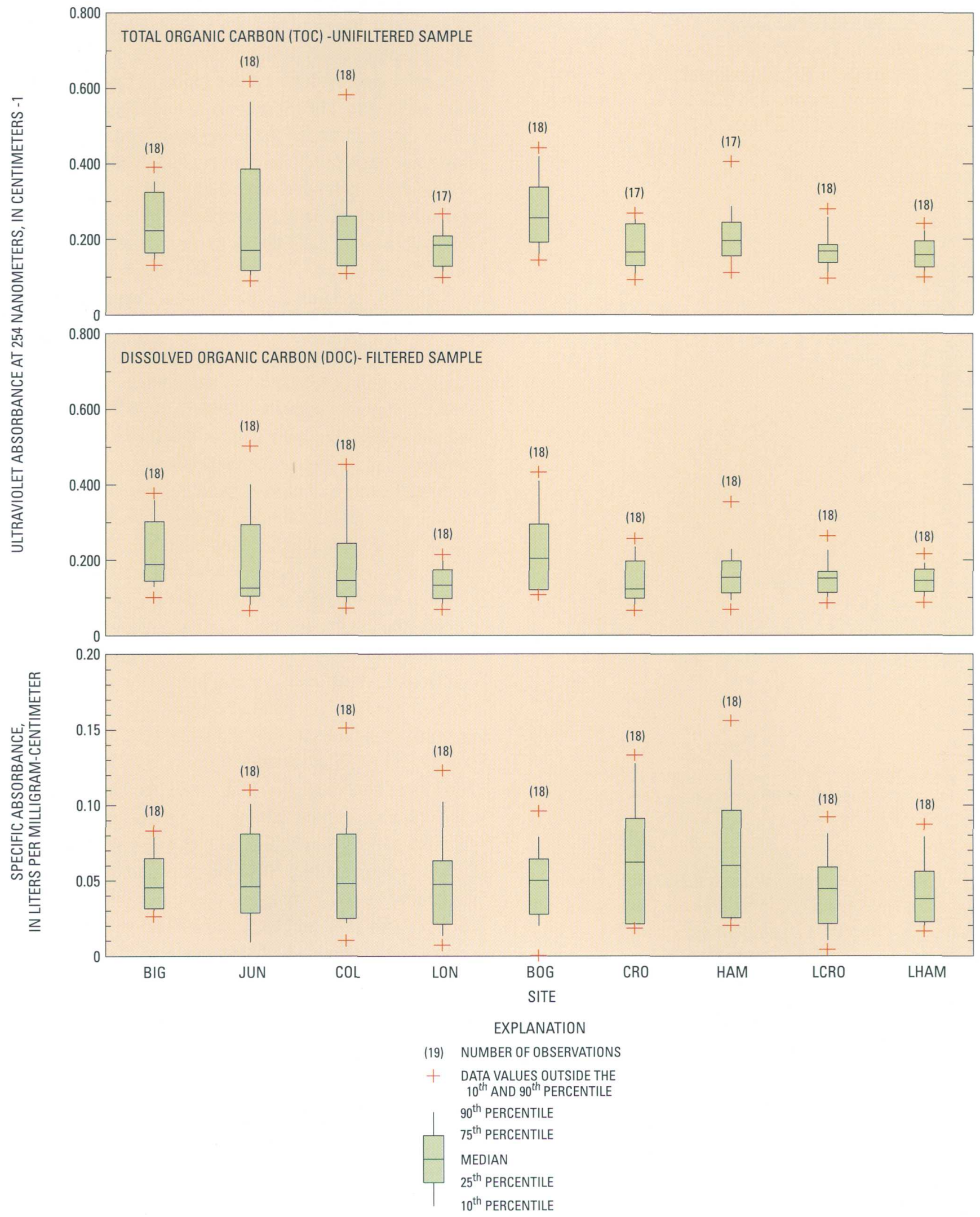

Figure 30. Boxplots of ultraviolet absorbance at 254 nanometers for unfiltered (TOC) and filtered (DOC) samples and specific absorbance at selected sites in the Converse Lake watershed, 1996-98. 
Big Creek (fig. 31). The median THM-FP concentration of five samples was $644 \mu \mathrm{g} / \mathrm{L}$ in Big Creek, $322 \mu \mathrm{g} / \mathrm{L}$ in Hamilton Creek, $318 \mu \mathrm{g} / \mathrm{L}$ in the lake at the pump station, and $277 \mu \mathrm{g} / \mathrm{L}$ in Crooked Creek (appendix 1). The highest THM-FP concentrations at all sites were found during or immediately after runoff events.

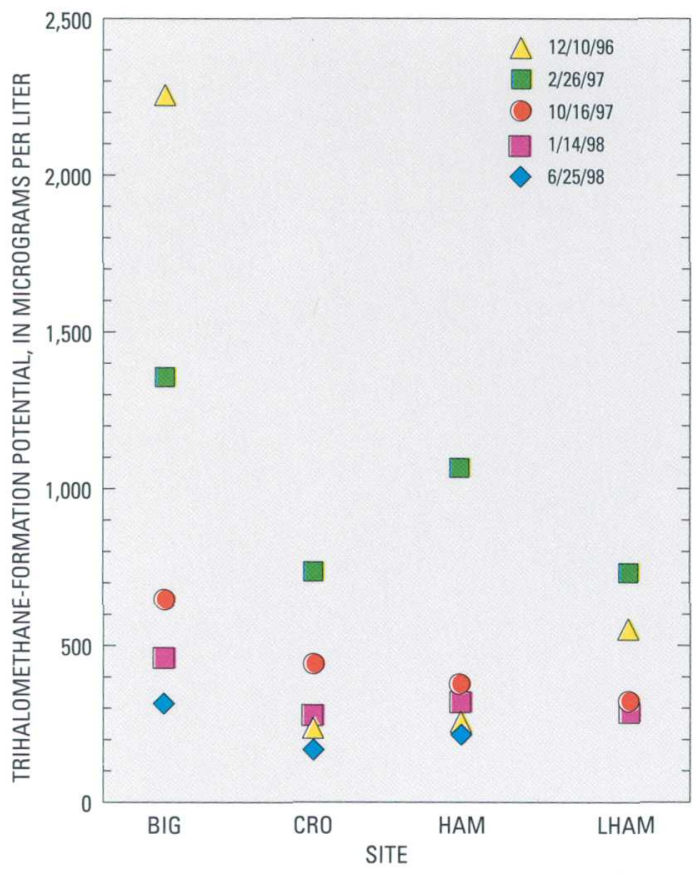

Figure 31. Range in trihalomethane-formation potential for selected tributary and lake sites in the Converse Lake watershed, 1996-98.

Previous investigations in California reported ranges in UVA from 0.255 to $1.33 \mathrm{~cm}^{-1}$ for agricultural drains and from 0.043 and $0.148 \mathrm{~cm}^{-1}$ for lakes and rivers (Amy and others, 1990; Krasner and others, 1994). In these same investigations, SUVA ranged from 0.038 to $0.060 \mathrm{~cm}^{-1} / \mathrm{mg} / \mathrm{L}$ for agricultural drains and from 0.017 to $0.034 \mathrm{~cm}^{-1} / \mathrm{mg} / \mathrm{L}$ for lakes and rivers. In the Converse Lake study, UVA and SUVA values at the lake sites, especially at the pump station, were within the same range as those values found in the California lakes and rivers. The tributary sites had UVA and SUVA values that overlapped the lower range for agricultural drains and the upper range for rivers in California. THM-FP levels ranged from 239 to $4,526 \mu \mathrm{g} / \mathrm{L}$ in agricultural drains in California, and from 144 to $360 \mu \mathrm{g} / \mathrm{L}$ in rivers and lakes. In the Converse Lake study, the levels of THM-FP in Big Creek were within the range for agricultural drains in California; the other Converse Lake study sites had THM-FP levels that overlapped the two ranges.

The computed land-use percentages from 1992 MRLC data were correlated with median TOC, UVA, and tannin and lignin concentrations for each tributary subbasin. The degree of correlation was used to identify whether the more reactive organic carbon was related to natural (forested) conditions or anthropogenic influences in the watershed (fig. 32; table 24). Negative correlation coefficients indicated an inverse relation between land-use percentages and reactive organic carbon (the greater the land-use percentages in a subbasin, the less reactive the organic carbon); positive coefficients signified a direct relation (the greater the land-use percentages, the more reactive the organic carbon). Deciduous forests had a statistically significant positive correlation ( $p$-value $<0.05)$ to DOC $(0.8829)$, TOC (0.8571), and UVA-TOC (0.8214). Unlike the California agricultural drains, the agricultural land-use categories of row crop, and pasture and hay showed no significant correlation. High-intensity and low-intensity residential land-use categories were negatively correlated to TOC and DOC but had no significant correlation to tannin and lignin or UVA. These findings suggest that forested land contributed more reactive organic carbon to the watershed than land influenced by agricultural and residential activities. 


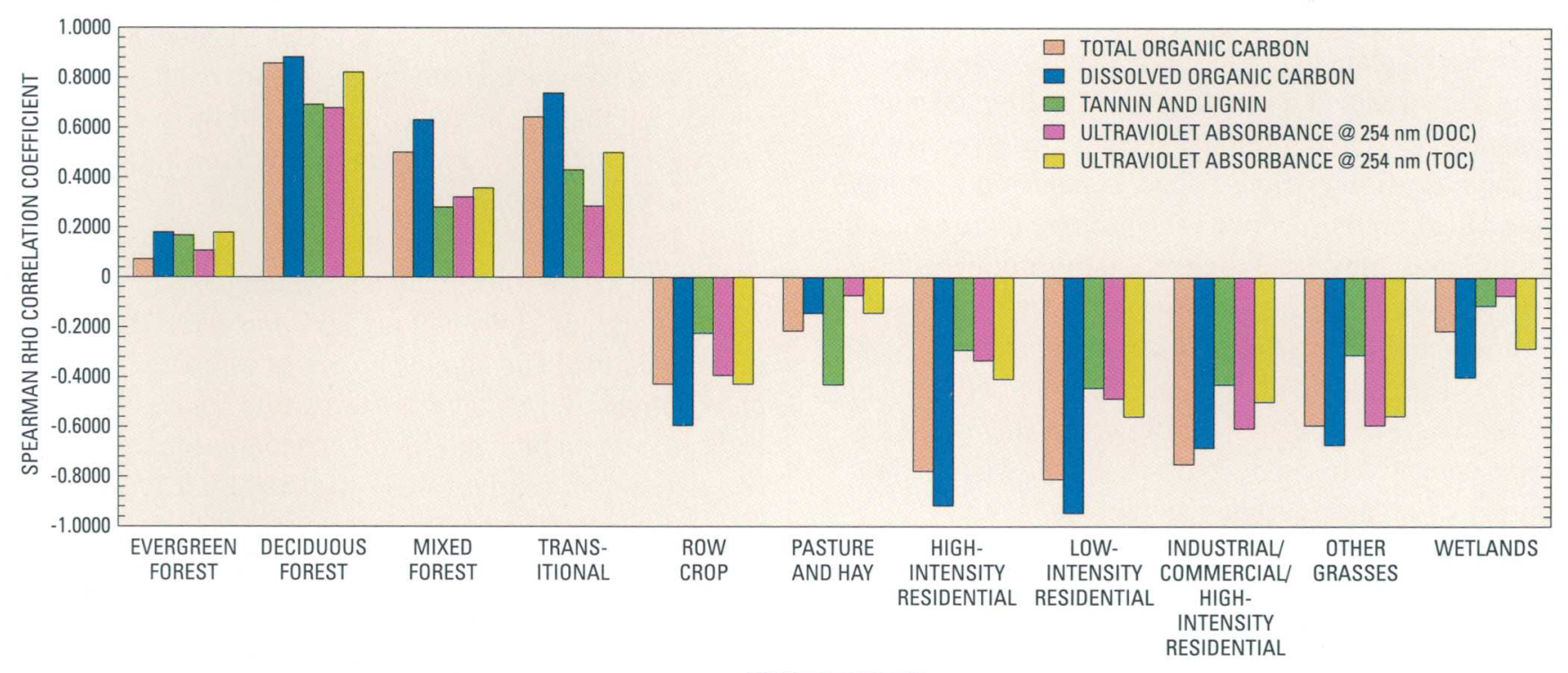

PERCENT LAND USE

Figure 32. Correlation between percent land-use categories and median concentrations of total organic carbon, dissolved organic carbon, tannin and lignin, and ultraviolet absorbance at 254 nanometers in the Converse Lake watershed, 1996-98.

Table 24. Spearman rho correlation coefficients for land-use categories and median levels of total organic carbon, dissolved organic carbon, tannin and lignin, and ultraviolet absorbance at 254 nanometers in the Converse Lake watershed

[Coefficients with statistically significant relations are bold ( $p$-value $<0.05$ ). MRLC, multi-resolution land characteristic]

\begin{tabular}{|c|c|c|c|c|c|}
\hline $\begin{array}{c}\text { MRLC } \\
\text { land-use category }\end{array}$ & $\begin{array}{c}\text { Total } \\
\text { organic } \\
\text { carbon }\end{array}$ & $\begin{array}{l}\text { Dissolved } \\
\text { organic } \\
\text { carbon }\end{array}$ & $\begin{array}{l}\text { Tannin } \\
\text { and } \\
\text { lignin }\end{array}$ & $\begin{array}{c}\text { Ultraviolet } \\
\text { absorbance at } \\
254 \text { nanometers } \\
\text { (dissolved) }\end{array}$ & $\begin{array}{c}\text { Ultraviolet } \\
\text { absorbance at } \\
254 \text { nanometers } \\
\text { (total) }\end{array}$ \\
\hline Evergreen forest & 0.0714 & 0.1802 & 0.1684 & 0.1071 & 0.1786 \\
\hline Deciduous forest & 0.8571 & 0.8829 & 0.6924 & 0.6786 & 0.8214 \\
\hline Mixed forest & 0.5000 & 0.6307 & 0.2807 & 0.3214 & 0.3571 \\
\hline Transitional & 0.6429 & 0.7388 & 0.4304 & 0.2857 & 0.5000 \\
\hline Row crops & -0.4286 & -0.5946 & -0.2245 & -0.3929 & -0.4286 \\
\hline Pasture and hay & -0.2143 & -0.1442 & -0.4304 & -0.0714 & -0.1429 \\
\hline High-intensity residential & -0.7783 & -0.9163 & -0.2912 & -0.3336 & -0.4077 \\
\hline Low-intensity residential & -0.8108 & -0.9455 & -0.4437 & -0.4865 & -0.5586 \\
\hline $\begin{array}{l}\text { Industrial/commercial/high- } \\
\text { intensity residential }\end{array}$ & -0.7500 & -0.6847 & -0.4304 & -0.6071 & -0.5000 \\
\hline Other grasses & -0.5930 & -0.6732 & -0.3107 & -0.5930 & -0.5559 \\
\hline Wetlands & -0.2143 & -0.4000 & -0.1123 & -0.0714 & -0.2857 \\
\hline
\end{tabular}




\section{Sources of Reactive Organic Carbon}

Tannin and lignin, derived from the breakdown of terrestrial plant material (leaves and crops), can enter lakes and streams by runoff or soil flushing during storm events or by continual seepage from the soil during base-flow periods. These organic compounds have a high amount of phenolic groups (more aromatic carbon) and, thus, tend to produce by-products during chlorination. Decaying organic matter in the lake sediment and algal growth also can contribute organic carbon. The organic compounds that are derived from algae have fewer phenolic groups and, therefore, a lower tendency to produce by-products. Manmade sources of organic carbon can include human wastewater (septic-tank effluent), livestock wastes, and cropland. These organic carbon compounds can vary in their tendencies to produce by-products.

At the tributary and lake sites, Spearman rho correlation coefficients were computed for UVA-TOC, UVA-DOC, specific absorbance, streamflow, TOC, $\mathrm{DOC}$, tannin and lignin, $\mathrm{pH}$, acid-neutralizing capacity, and water temperature (estimate of season) to determine the interrelations, if any, among these constituents (table 25). At all tributary sites, the strongest correlation was between UVA-TOC (selected as the best surrogate for trihalomethane-formation potential) and tannin and lignin, indicating a terrestrial source for the most reactive organic carbon. This correlation was statistically significant $(p$-value $<0.05$ ) for Big Creek (1.000), Juniper Creek (0.955), Boggy Branch (0.926), Crooked Creek (0.886), and Hamilton Creek (0.975). Statistically significant correlations $(p$-value $<0.05)$ also occurred between tannin and lignin and TOC and DOC, respectively, at Juniper Creek (0.941, 0.941), Boggy Branch (0.940, 0.926), Crooked Creek $(0.943,0.886)$, and Hamilton Creek $(0.947,0.975$; table 25$)$, indicating that the major source of all organic carbon compounds in these streams was terrestrial. No statistically significant correlation was found between streamflow and tannin and lignin concentrations, UVA-TOC, UVA-DOC, or specific absorbance at any of the tributary sites, suggesting that the reactive organic carbon reaches the streams from the soil and litter zone during both runoff and base-flow seepage.

For the lake sites, Spearman rho correlations were used to determine whether the major source of the reactive organic carbon in the lake was terrestrial or algal in nature. The algal source was estimated by chlorophyll $a$ levels, and the terrestrial source was estimated by tannin and lignin concentrations. The reactive organic carbon was estimated by UVA-TOC, which was identified as the best surrogate for THM-FP, and UVA-DOC. An extremely strong, positive, statistically significant correlation $(p$-value $<0.01)$ was found between chlorophyll $a$, TOC, and DOC (1.000; table 25), indicating that the major source of organic carbon in the lake was algae. The correlations, however, between UVA-TOC, UVA-DOC, chlorophyll $a$, TOC, and DOC were not statistically significant. UVA-TOC had the strongest correlation with tannin and lignin concentrations (0.949), indicating a terrestrial source for the most reactive organic carbon.

In summary, naturally occurring, terrestrial organic carbon compounds from decaying organic material such as fallen leaves were the major source of reactive organic carbon in the Converse Lake watershed. In the lake, algae was considered the major source of organic carbon as indicated by strong, positive, statistically significant correlations among chlorophyll $a$, TOC, and DOC. The algal-derived organic carbon, however, was not considered the major source of the reactive organic carbon as indicated by the absence of significant statistical correlations among chlorophyll $a$, TOC, DOC, and UVA (the surrogate used to represent THM-FP). 

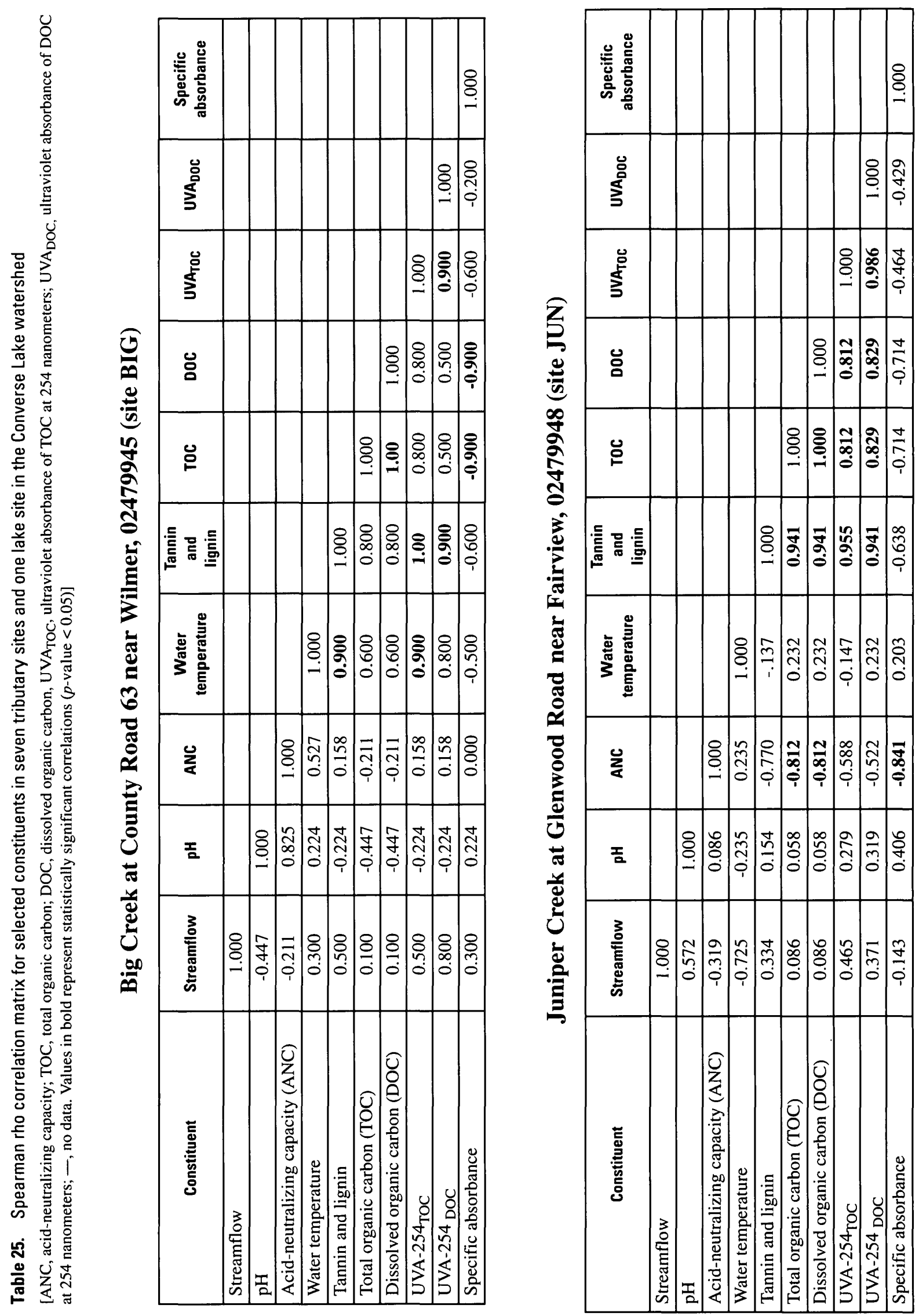

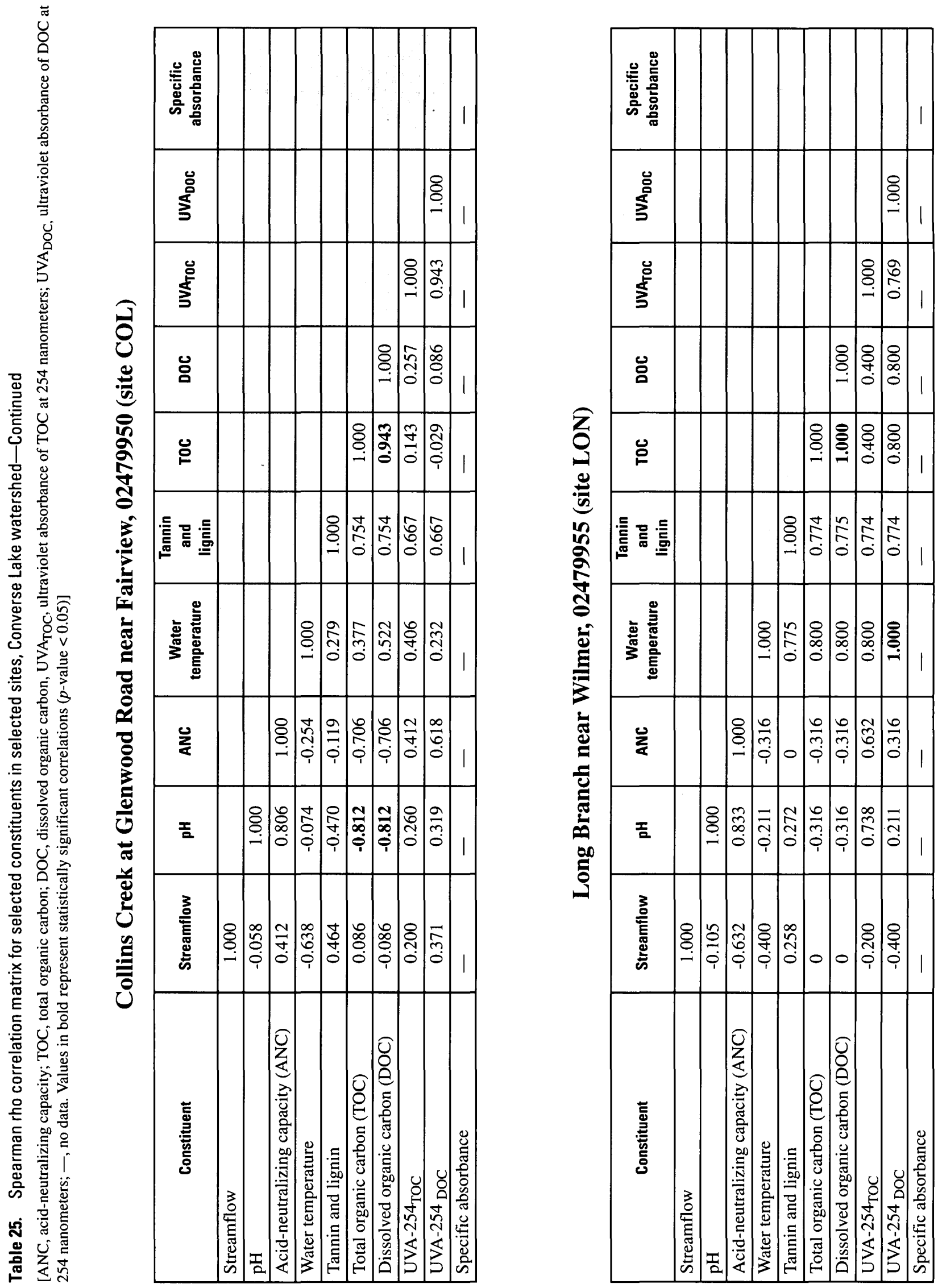

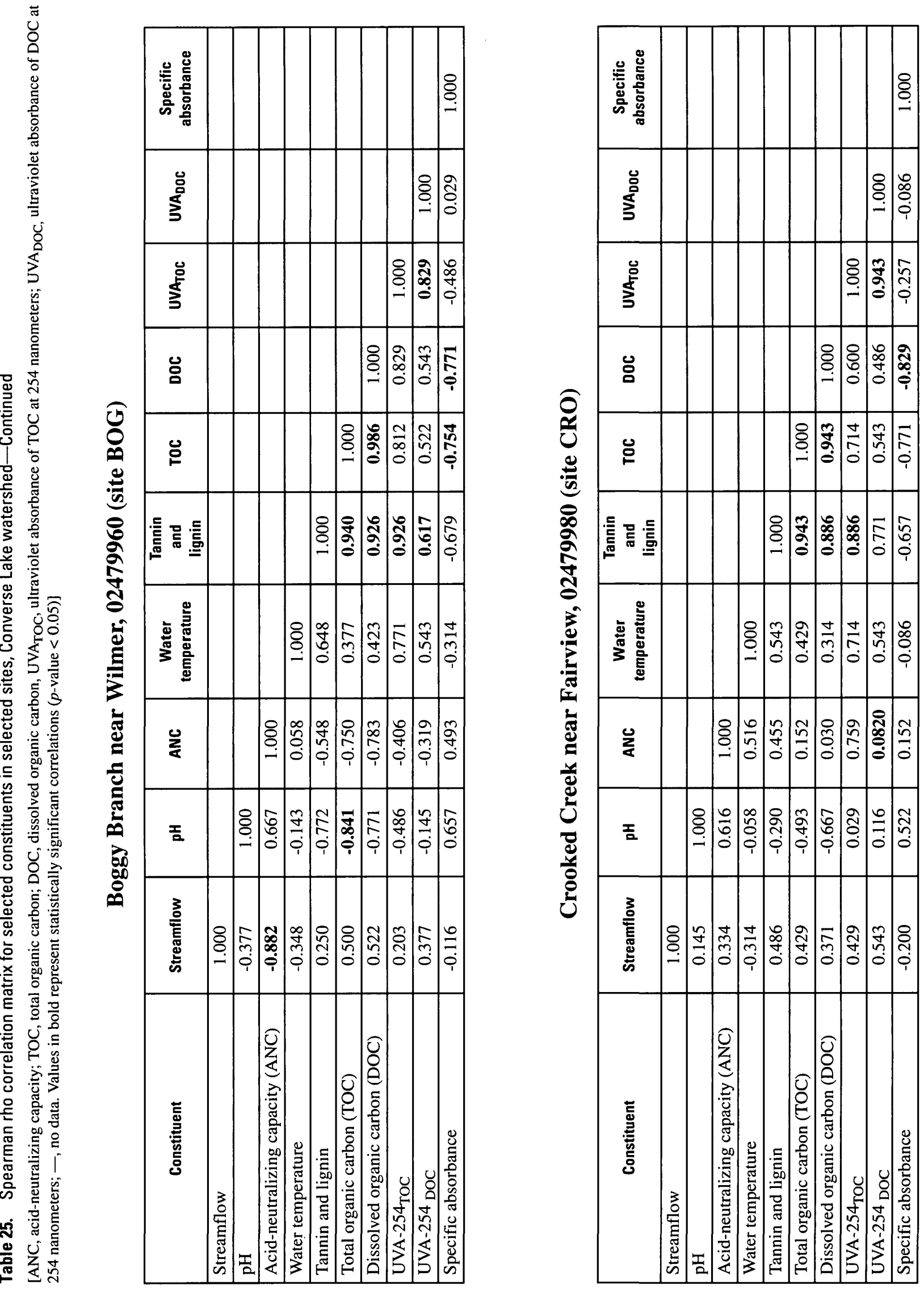

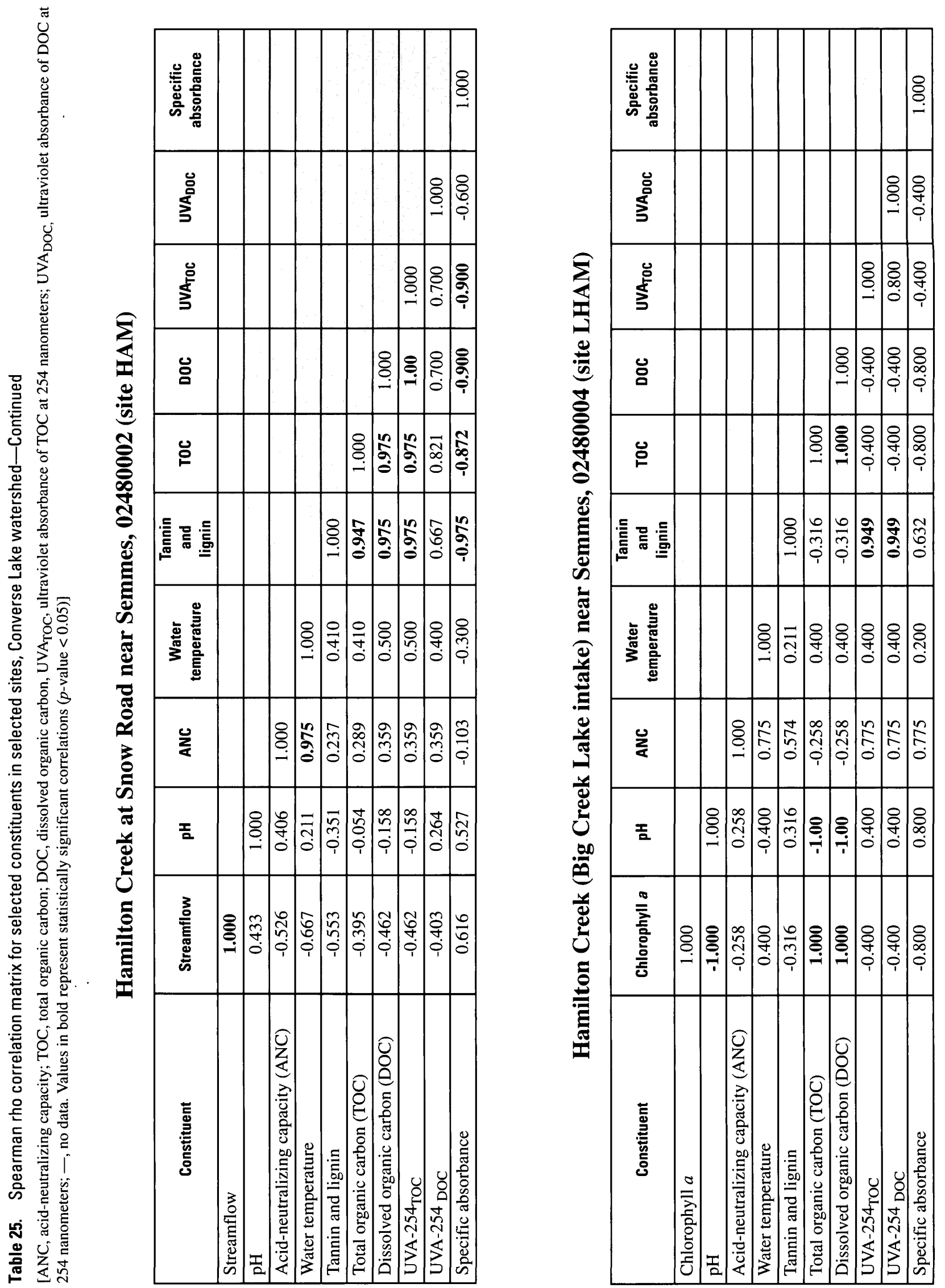


\section{SUMMARY AND CONCLUSIONS}

J.B. Converse (Converse) Lake is a 3,600-acre, tributary-storage reservoir in southwestern Alabama. The $103-\mathrm{mi}^{2}$ watershed is located in Mobile County west of the city of Mobile near the AlabamaMississippi State line. The lake is designated for aquatic-life and public-water supply use by the ADEM.

The climate in the Converse Lake watershed is subtropical. The mean annual precipitation for the Mobile area is 64 in.; the mean annual temperature is $67.5^{\circ} \mathrm{F}$. The study area lies within a single district of the Coastal Plain Physiographic Province-the Southern Pine Hills District of the East Gulf Coastal Plain Physiographic section. Two geologic units of Tertiary age, the Miocene Series undifferentiated and the Citronelle Formation of Pliocene age, underlie the watershed and consist of semiconsolidated to unconsolidated sand, silt, gravel, and clay. These units dip and thicken to the southwest.

Converse Lake receives inflow from seven major tributaries that drain about three-fourths of the total watershed; three of the tributaries are monitored by streamflow gages. Big Creek, Crooked Creek, and Hamilton Creek had mean annual streamflows of 72.2, 19.4 , and $25.0 \mathrm{ft}^{3} / \mathrm{s}$, respectively, for the period 1990 to 1998. Hamilton Creek subbasin had the greatest streamflow yield of $3.04\left(\mathrm{ft}^{3} / \mathrm{s}\right) / \mathrm{mi}^{2}$; Crooked and Big Creeks had yields of 2.40 and $2.29\left(\mathrm{ft}^{3} / \mathrm{s}\right) / \mathrm{mi}^{2}$, respectively. Hamilton Creek had better sustained flows and contributed increasingly greater percentages of the total inflow to the lake during low-flow periods, until it equaled or slightly exceeded the streamflow yield at Big Creek.

The Converse Lake watershed is forested and rural. Forests cover over 64 percent of the watershed; agricultural use accounts for about 31 percent of the watershed. Residential and commercial development account for only 1 percent of the total land use in the watershed. The Big Creek subbasin is covered by forested land with some agricultural land. The Crooked Creek subbasin has the greatest percentage of agricultural land use (42 percent) in the watershed, consisting mostly of plant nurseries. The percentage of residential area (3.4 percent) in the Crooked Creek subbasin is second only to the amount of residential land use in the Hamilton Creek subbasin (3.9 percent). Point sources in the watershed consist of two hazardous- and solid-waste sites and two permitted compliance system sites; no waste or by-product releases (to air, water, or ground water) were reported during the study period.

Waters in Converse Lake and its tributaries have low $\mathrm{pH}$ and low specific conductance values, which is typical of waters in humid climates that drain highly resistant sands and gravels. Although all sites in the Converse Lake watershed had $\mathrm{pH}$ levels that periodically fell below the ADEM criterion of 6, Big Creek and Boggy Branch had median pH values of 5.6 and 5.9, respectively. Statistical correlations indicated that the greater the amount of commercial, industrial, and residential development (human influences), the greater the tendency for the streamwater to have a more neutral median $\mathrm{pH}$ and a greater capacity to neutralize acid. This correlation, in conjunction with the environmental factors of resistant rock types and acidic soil in the watershed, provide a strong indication that low $\mathrm{pH}$ and low ANCs are natural in origin, and not anthropogenic. The median specific conductance ranged from 23 (Collins Creek) to $43 \mu \mathrm{S} / \mathrm{cm}$ (Long Branch) for the study period.

All tributary sites in the Converse Lake watershed had minimum dissolved-oxygen concentrations above the ADEM criteria of $5 \mathrm{mg} / \mathrm{L}$ except for Boggy Branch, which had a minimum dissolved-oxygen concentration of $3.7 \mathrm{mg} / \mathrm{L}$. Median dissolved-oxygen concentrations ranged from 6.9 (Boggy Branch) to $8.6 \mathrm{mg} / \mathrm{L}$ (Juniper Creek and Long Branch) for the study period. Converse Lake becomes stratified during August and September when dissolved-oxygen levels typically fall below $1 \mathrm{mg} / \mathrm{L}$ at depths greater than $20 \mathrm{ft}$.

No substantial differences were observed in water chemistry among tributary sites. Big Creek had a relatively high nitrate component, especially during base-flow periods, suggesting a ground-water source. Increases in calcium and bicarbonate concentrations in Crooked Creek and Hamilton Creek during high streamflow periods suggested a runoff or soil-zone flushing source. Converse Lake and its tributaries had median total iron concentrations that exceeded the ADEM secondary standard for drinking water of $300 \mu \mathrm{g} / \mathrm{L}$; only Boggy Branch had median total manganese concentrations that exceeded the secondary standard of $50 \mu \mathrm{g} / \mathrm{L}$.

Total nitrogen (with the exception of Long Branch), total Kjeldahl nitrogen (with the exception of Hamilton Creek), total organic nitrogen (with the exception of Boggy Branch), ammonia (with the exception of Long Branch), total inorganic nitrogen, 
and total phosphorus (with the exception of Long and Boggy Branches) exhibited a significant, positive relation with streamflow, which indicates the dominant source of nutrient input to the watershed is from nonpoint sources.

In comparison to published values, the computed total phosphorus yields for Big Creek, Collins Creek, Long Branch, and Boggy Branch were within the expected range of forested land that had minor agriculture (pasture, crops, mixed agriculture). Total phosphorus yields were higher in the Crooked and Hamilton Creek subbasins $(0.52$ and $0.40(\mathrm{~kg} / \mathrm{ha}) / \mathrm{yr}$, respectively) compared to the other tributary subbasins, probably as a result of higher percentages of residential and nonrow crop (plant nurseries) land use in these subbasins. Juniper Creek subbasin had a similar total phosphorus yield of $0.45(\mathrm{~kg} / \mathrm{ha}) / \mathrm{yr}$ present but little to no residential influence. The total nitrogen yields at the tributary sites also fell within the published ranges for forest, agriculture (pasture, nonrow crops), and urban land uses.

For the 1991 water year, the total phosphorus yields ranged from 0.10 (Long Branch) to 0.52 (kg/ha)/yr (Crooked Creek); total nitrogen yields ranged from 3.83 (Collins Creek) to $8.45(\mathrm{~kg} / \mathrm{ha}) / \mathrm{yr}$ (Big Creek). The nutrient loads at Big Creek, Crooked Creek, and Hamilton Creek accounted for over 70 percent of the total load in the watershed. Big Creek had the highest nutrient loads, accounting for almost 60 percent of the total nitrogen and total Kjeldahl nitrogen, 47 percent of the total inorganic nitrogen, and 36 percent of total phosphorus loads. Crooked and Juniper Creeks each contributed 21 percent of the total phosphorus load in 1991; Hamilton Creek contributed about 16 percent of the total phosphorus load. Total phosphorus yields from Crooked, Juniper, and Hamilton Creek subbasins were 2 to 5 times those of the other tributary subbasins.

During the study period, annual nutrient loads and yields were highest for the 1991 and 1998 water years and lowest for the 1992 and 1994 water years (with the exception of total inorganic nitrogen in 1995). A combined mean annual load of $75,400 \mathrm{~kg}$ of total nitrogen, $36,950 \mathrm{~kg}$ of total Kjeldahl nitrogen, $28,870 \mathrm{~kg}$ of total inorganic nitrogen, and $3,480 \mathrm{~kg}$ of total phosphorus were contributed to the lake by Big Creek, Hamilton Creek, and Crooked Creek. Of the combined loads, 62 percent of the total nitrogen, 81 percent of the total Kjeldahl nitrogen, 54 percent of the total inorganic nitrogen, and 47 percent of the total phosphorus originated from the forested subbasin of Big Creek. The more residential and agricultural subbasins of Crooked Creek and Hamilton Creek, however, yielded over twice the total phosphorus per hectare of land use. Crooked and Hamilton Creek subbasins also had higher total inorganic nitrogen yields. The mean annual nutrient yields were averaged to obtain a watershed yield for each nutrient species- $0.0933(\mathrm{~kg} / \mathrm{ha}) / \mathrm{yr}$ of orthophosphate, $0.358(\mathrm{~kg} / \mathrm{ha}) / \mathrm{yr}$ of total phosphorus, $2.72(\mathrm{~kg} / \mathrm{ha}) / \mathrm{yr}$ of total inorganic nitrogen, $0.0035(\mathrm{~kg} / \mathrm{ha}) / \mathrm{yr}$ of total ammonia, $3.20(\mathrm{~kg} / \mathrm{ha}) / \mathrm{yr}$ of total Kjeldahl nitrogen, and $6.46(\mathrm{~kg} / \mathrm{ha}) / \mathrm{yr}$ of total nitrogen.

The trend analysis detected little or no change in nutrient concentrations at the tributary and lake sites in the Converse Lake watershed for the 1991 to 1998 water years. A complex relation seemed to exist between annual nutrient contributions to Converse Lake from the tributaries, and the lake's ability to assimilate these contributions by biomass uptake, sedimentation, and outflow. The lack-of-fit of the estimated in-lake phosphorus concentration from a simple input-output empirical model to the observed value in Converse Lake accentuated the need for a more robust model of lake water quality and trophic response.

Monitoring in the Converse Lake watershed showed that some tributaries to the lake had fecal bacterial concentrations that were above the ADEM criteria for whole-body contact uses. Bacterial concentrations at lake sites at the mouth of Crooked Creek and Hamilton Creek at the pump station were well below ADEM criteria levels. Elevated bacterial concentrations in the tributaries did not appear to cause elevated levels in the lake.

Juniper Creek had the highest geometric mean concentrations for all bacteria types during the study. Trend analysis indicated that flow-adjusted fecal streptococcus concentrations increased at Juniper Creek during the 8 years of data collection. The increasing trend in bacteria is cause for concern because the median fecal bacteria levels in Juniper Creek for 1990-98 were above the ADEM whole-body criteria levels.

There were few detections of Giardia and Cryptosporidium at sites in the lake and in the rawwater intake during the monitoring effort. The low number of detections made it difficult to arrive at any conclusions about actual cyst concentrations in the water supply. Most of the detections occurred during 
the summer, but so few cysts were detected that it is not clear if there is a seasonal influence on cyst density.

In the Converse Lake watershed, naturally occurring, terrestrial organic carbon compounds derived from decaying organic material, such as fallen leaves, were the major source of reactive organic carbon, which tends to form trihalomethanes in the presence of chlorine. In the lake, algae was considered the major source of organic carbon as indicated by strong, positive, statistically significant correlations among chlorophyll $a$, TOC, and DOC. The algalderived organic carbon, however, was not considered a major source of the reactive organic carbon as indicated by the absence of significant statistical correlations between chlorophyll $a$, TOC, DOC, and UVA (the surrogate used to represent THM-FP).

In conclusion, water quality in Converse Lake and its tributaries meets the criteria mandated by the ADEM and the Clean Water Act, which require that all waters be "fishable and swimmable." The exceptions include natural acidic $\mathrm{pH}$ levels, iron and manganese levels above secondary or aesthetic criteria, and fecal bacterial levels in some tributaries above "swimmable" criteria. Water-management concerns also include potential sources of reactive organic carbon that form trihalomethanes when raw water is chlorinated, and excessive nutrient loads to the lake that can produce borderline mesotrophic/eutrophic conditions.

Results of this study have long-range watershed management implications. Though the low $\mathrm{pH}$ levels seem to be naturally occurring, future changes in land use could lower $\mathrm{pH}$ levels even more, especially since the soils have very little acid-neutralizing capacity. Identification of fecal bacterial sources, and implementation and evaluation of best-management practices, may be considered to prevent bacterial contamination in the lake. The major source of reactive organic carbon was determined to be from the decay of plant material from land rather than from in-lake algal production. The trophic state of the lake seems to be moving toward a more eutrophic state; however, the changes are not fully explained by nutrient contributions from the tributaries to the lake. A better understanding of the major factors affecting the trophic state of the lake is needed.

\section{SELECTED REFERENCES}

Aiken, G.R., and Cotsaris, E., 1995, Soil and hydrology-Their effect on NOM: Journal of the American Water Works Association, p. 36-45.

Alabama Department of Environmental Management, 1994a, Water quality criteria: Alabama Department of Environmental Management Administrative Code, chap. 335-6-10.

- 1994b, Water use classifications for interstate and intrastate waters: Alabama Department of Environmental Management Administrative Code, chap. 335-6-11, $47 \mathrm{p}$.

1996, 305(b) Water-quality report to Congress for calendar years 1994 and 1995: Montgomery, Alabama Department of Environmental Management, $278 \mathrm{p}$.

-1999, 305(b) Water-quality report to Congress for calendar years 1997 and 1998: Montgomery, Alabama Department of Environmental Management, Part III-7, Section G, 320 .

2000, Water quality criteria: Alabama Department of Environmental Management Administrative Code, chaps. 335-6-10 and 335-6-11.

Amy, G.L., Thompson, J.M., Tan, L., Davis, M.K., and Krasner, S.W., 1990, Evaluation of THM precursors from agricultural drains: Journal of American Water Works Association, v. 82, no. 1, p. 57-64.

Amy, G.L., Wilson, L.G., Conroy, A., Chahbandour, J., Zhai, W., and Siddiqui, M., 1993, Fate of chlorination byproducts and nitrogen species during effluent recharge and soil aquifer treatment (SAT): Water Environment Research, v. 65, no. 6, p. 726-734.

Atkins, J.B., and Pearman, J.L., 1994, Low-flow and flowduration characteristics of Alabama streams: U.S. Geological Survey Water-Resources Investigations Report 93-4186, $264 \mathrm{p}$.

Barber, L.B., II, Brown, G.K., Kennedy, K.R., Leenheer, J.A., Noyes, T.I., Rostad, C.E., Thorn, K.A., 1997, in Kendall, D.R., ed., Proceedings of the American Water Resources Association Symposium, Conjunctive use of water resources, aquifer storage and recovery: October 19-23, 1997, Long Beach, Calif., p. 261-272.

Bayne, D.R., Seesock, W.C., and Reutebuch, E.M., 1998, Limnological study of Big Creek Lake: Department of Fisheries and Allied Aquaculture, Alabama Agricultural Experiment Station, Auburn University, $74 \mathrm{p}$.

Bradu, D., and Mundlak, Y., 1970, Estimation in lognormal linear models: Journal of the American Statistical Association, v. 65, no. 329, p. 198-211.

Carlson, R.E., 1977, A trophic state index for lakes: Limnology and Oceanography, v. 22, no. 2, p. 361-369. 
Chapra, S.C., 1975, Comment on "An empirical method of estimating retention of phosphorus in lakes" by W.B. Kirchner and P.J. Dillon: Water Resources Research, v. 11, p. 1033-1034.

Cohn, T.A., 1988, Adjusted maximum likelihood estimation of the moments of lognormal populations from type 1 censored samples: U.S. Geological Survey Open-File Report 88-350, 34 p.

Cohn, T.A., Caulder, D.L., Gilroy, E.J., Zynjuk, L.D., and Summers, R.M., 1992, The validity of a simple statistical model for estimating fluvial constituent loads-An empirical study involving nutrient loads entering Chesapeake Bay: Water Resources Research, v. 28 , no. 5 , p. 937-942.

Cohn, T.A., DeLong, L.L., Gilroy, E.J., Hirsch, R.M., and Wells, D.K., 1989, Estimating constituent loads: Water Resources Research, v. 25, no. 5, p. 937-942.

Conrad, Laura, 1998, The tedious hunt for Cryptosporidium: Today's Chemist at Work, American Chemical Society, March 1998, p. 24-28.

Davis, M.E., 1987, Stratigraphic and hydrogeologic framework of the Alabama Coastal Plain: U.S. Geological Survey Water-Resources Investigations Report 87-4112, 39 p., + 17 pls.

de Leer, E.W., and Erkelens, C., 1989, Pathways for the production of organochlorine compounds in the chlorination of humic materials, in Larson, R.A., ed., Biohazards of drinking water treatment: Boca Raton, Fla., Lewis Publishers, p. 97-106.

Dillon, P.J., and Kirchner, W.B., 1975, Reply to Chapra's comment on "An empirical method of estimating retention of phosphorus in lakes" by W.B. Kirchner and P.J. Dillon: Water Resources Research, v. 11, p. 1035-1036.

Drever, J.I., 1988, The geochemistry of natural waters: Englewood Cliffs, N.J., Prentice Hall, Inc., 437 p.

Dufour, A.P., 1977, Escherichia coli-the fecal coliform, in Hoadley, A., and Dutka, B.J., eds., Bacterial indicators/health hazards associated with water, 1977: American Society for Testing and Materials, ASTM STP 635, p. 222-238.

Edminston, H.L., and Myers, V.B., 1984, Florida lakes assessment-Combining macrophyte, chlorophyll, nutrient, and public benefit parameters into a meaningful lake management scheme-Lake and Reservoir Management, Proceedings of the Third Annual Conference of the North American Lake Management Society: October 18-20, 1993, Knoxville, Tenn., U.S. Environmental Protection Agency 440.5/84-001, p. 25-39.

Gakstatter, J.H., Allum, M.O., and Omernik, J.M., 1975, Lake eutrophication-Results from the National Eutrophication Survey: United States Environmental Protection Agency, Corvallis, Oreg., Corvallis Environmental Research Lab, 32 p.
Gilroy, E.J., Hirsch, R.M., and Cohn, T.A., 1990, Mean square error of regression-based constituent transport estimates: Water Resources Research, v. 26, no. 9, p. 2069-2077.

Greenberg, A.E., Clesceri, L.S., Eaton, A.D., and Franson, M.H., eds., 1992a, Part 5710B, Trihalomethane formation potential (TFP)_-Standard methods for the examination of water and wastewater [18th ed.]: Washington, D.C., American Public Health Association, American Water Works Association, and the Water Environment Federation, p. 5-45-5-48.

- 1992b, Part 9711B, Giardia lamblia-Standard methods for the examination of water and wastewater [18th ed.]: Washington, D.C., p. 9-124-9-128.

Hajek, B.F., Gilbert, F.L., and Steers, C.A., 1975, Soil associations of Alabama: Auburn, Ala., U.S. Department of Agriculture, Agricultural Experimental Station, Agronomy and Soils Department, Series No. 24,30 p.

Helsel, D.R., 1987, Advantages of nonparametric procedures for analysis of water quality data: Hydrological Sciences, v. 32, p. 179-190.

Helsel, D.R., and Hirsch, R.M., 1992, Statistical methods in water resources: New York, Elsevier, 522 p.

Hem, J.D., 1985, Study and interpretation of the chemical characteristics of natural water: U.S. Geological Survey Water-Supply Paper 2254, 263 p.

Hibler, C.P., and Hancock, C.M., 1990, Waterborne giardiasis, in McFeters, G.A., ed., Drinking water microbiology-Progress and recent developments: New York, Springer-Verlag, p. 271-290.

Hirsch, R.M., Slack, J.R., and Smith, R.A., 1982, Techniques of trend analysis for monthly water quality data: Water Resources Research, v. 20, p. 727-732.

Journey, C.A., Psinakis, W.L., and Atkins, J.B., 1995, Streamflow in and water quality and bottom material analyses of the J.B. Converse Lake Basin, Mobile County, Alabama, 1990-1992: U.S. Geological Survey Water-Resources Investigations Report 95-4106, $69 \mathrm{p}$.

Kirchner, W.B., and Dillon, P.J., 1975, An empirical method of estimating the retention of phosphorus in lakes: Water Resources Research, v. 11, p. 182-183.

Korshin, G.V., Li, C., and Benjamin, M.M., 1997, Monitoring the properties of natural organic matter through UV spectroscopy-A consistent theory: Water Research, v. 31, no. 7, p. 1787-1795.

Krasner, S.W., Sclimenti, M.J., and Means, E.G., 1994, Quality degradation-Implications for DBP formation: Journal of American Water Works Association, v. 70, p. 653-660. 
Larsen, D.P., and Mercier, H.T., 1976, Phosphorus retention capacity of lakes: Journal of the Fisheries Research Board of Canada, v. 33, p. 1742-1750.

Larson, R.A., and Weber, E.J., 1994, Reaction mechanisms in environmental organic chemistry: Boca Raton, Fla., Lewis Publishers.

Likens, G.E., and Bormann, F.H., 1995, Biogeochemistry of a forested ecosystem, (2d ed.): New York, SpringerVerlag, 159 p.

Miller, R.E., Randtke, S.J., Hathaway, L.R., and Denne, J.E., 1990, Organic carbon and THM formation potential in Kansas groundwaters: Journal of American Water Works Association, v. 82, p. 49-62.

Mooty, W.S., 1988, Geohydrology and susceptibility of major aquifers to surface contamination in Alabama; Area 13: U.S. Geological Survey Water-Resources Investigations Report 88-4080, 29 p.

Myers, D.N., and Wilde, F.D., eds., 1999, Biological indicators-National field manual for the collection of water-quality data: U.S. Geological Survey Techniques of Water-Resources Investigations, book 9 , chap. A7.

National Oceanic and Atmospheric Administration, National Climate Data Center, 1998, U.S. monthly precipitation for cooperative and National Weather Service sites: accessed September 1, 1998, at URL http://www.ncdc.noaa.gov/ol/climate/online/ coop-precip.html for Mobile Regional Airport station 015478.

Nieminski, E.C., Chaudhuri, S., and Lamoreaux, T.J., 1993, The occurrence of DBPs in Utah drinking waters: Journal of the American Water Works Association, v. 85 , p. $98-105$.

Pearman, J.L., Sedberry, F.C., Stricklin, V.E., and Cole, P.W. 1991, Water resources data, Alabama, water year 1991: U.S. Geological Survey Water-Data Report AL-91-1, $475 \mathrm{p}$.

1992, Water resources data, Alabama, water year 1992: U.S. Geological Survey Water-Data Report AL-92-1, $457 \mathrm{p}$.

Pearman, J.L., Stricklin, V.E., and Psinakis, W.L., 1998, Water resources data, Alabama, water year 1998: U.S. Geological Survey Water-Data Report AL-98-1, 444 p.

Porcella, D.B., Peterson, S.A., and Larsen, D.P., 1980, Index to evaluate lake restoration: Proceedings of the American Society of Civil Engineers, Journal of the Environmental Engineering Division, v. 106, p. 1151-1169.

Rast, W., and Lee, G.F., 1978, Summary analysis of the North American Project (U.S. portion) OECD Eutrophication Project-Nutrient loading-lake response relationships and trophic stat indices: U.S. Environmental Protection Agency, Corvallis, Oreg., Corvallis Environmental Research Laboratory, Report EPA-600/3-78-008, 455 p.
Rathbun, R.E., 1996, Disinfection by-product yields from the chlorination of natural waters: Archives of Environmental Contamination and Toxicology, v. 31, no. 3, p. 420-425.

Reckhow, D.A., Singer, P.C., and Malcolm, R.L., 1990, Chlorination of humic materials-Byproduct formation and chemical interpretations: Journal of American Water Works Association, v. 24, p. 1655-1664.

Reckhow, K.H., 1979, Empirical lake models for phosphorus-Development, applications, uncertainty, in Scavia, D., and Robertson, A., eds., Perspectives on lake ecosystems modeling: Ann Arbor, Mich., Ann Arbor Science, p. 193-222.

Reckhow, K.H., Beaulac, M.N., and Simpson, J.T., 1980, Modeling phosphorus loading and lake response under uncertainty-A manual and compilation of export coefficients: U.S. Environmental Protection Agency, Office of Water Regulations and Standards, EPA 440/580-011, 214 p.

Reckhow, K.H., and Clements, J.T., 1984, A cross-sectional model for phosphorus in southeastern U.S. lakes-Lake and reservoir management, Proceedings of the Third Annual Conference of the North American Lake Management Society: October 18-20, 1993, Knoxville, Tenn., U.S. Environmental Protection Agency 440.5/84-001, p. 186-192.

Reed, P.C., 1971, Geology of Mobile County, Alabama: Tuscaloosa, Geological Survey of Alabama, Map 93, $8 \mathrm{p}$.

Reed, P.C., and McCain, J.F., 1972, Water availability in Mobile County, Alabama: Tuscaloosa, Geological Survey of Alabama, Map 121, 45 p.

Reutebuch, E.M., Bayne, D.R., and Seesock, W.C., 1997, Land use/land cover changes in the Big Creek watershed derived from Landsat TM data-1984-1995: Auburn, Ala., Auburn University, 16 p.

Rook, J.J., 1977, Chlorination reactions of fulvic acids in natural waters: Environmental Science and Technology, v. 11, p. $478-482$.

Rose, J.B., 1990, Occurrence and control of Cryptosporidium in drinking water, Chapter 14, in McFeters, G.A., ed., Drinking water microbiology-Progress and recent developments: New York, Springer-Verlag, p. 294-321.

Sapp, D.C., and Emplaincourt, J., 1975, Physiographic regions of Alabama: Geological Survey of Alabama, Map 168, 1 sheet.

Searcy, J.K., 1959, Flow-duration curves: U.S. Geological Survey Water-Supply Paper 1542-A, 33 p.

Silverstein, R.M., Bassler, G.C., Morrill, T.C., 1991, Spectrometric identification of organic compounds (5th ed.): New York, John Wiley \& Sons, Inc., $419 \mathrm{p}$. 
Singer, P.C., Obolensky, A., and Grenier, A.J., 1995, DBPs in chlorinated North Carolina drinking waters: Journal of the American Water Works Association, v. 87, no. 10 , p. 83-102.

Snoeyink, V.L., and Jenkins, D., 1980, Water chemistry: New York, John Wiley \& Sons, Inc., 463 p.

Stumm, W., and Morgan, J.J., 1996, Aquatic chemistry-Chemical equilibria and rates in natural waters ( $3 \mathrm{~d}$ ed.): New York, John Wiley \& Sons, Inc., $1022 \mathrm{p}$.

Summers, R.S., Hooper, S.M., Shukairy, H.M., Solarik, G., and Owen, D. J., 1996, Assessing DBP yield-Uniform formation conditions: Journal of the American Water Works Association, v. 88, no. 6, p. 80-93.

Symons, J.M., Stevens, A.A., Clark, R.M., Geldreich, E.E., Love, O.T., Jr., and DeMarco, J., 1981, Treatment techniques for controlling trihalomethanes in drinking water: U.S. Environmental Protection Agency, EPA 600/2-81-156.

U.S. Department of Agriculture, 1994, State Soil Geographic (STATSGO) database for Alabama: U.S. Department of Ágriculture, Natural Resources Conservation Service, Soil Survey Division, accessed July 31, 2001, at URL http://www.ftw.nrcs.usda.gov/ stat_data.html.

U.S. Environmental Protection Agency, 1981, Clean lakes program guidance manual: U.S. Environmental Protection Agency, EPA 440/5-81-003.

1986, Ambient water quality criteria for bacteria-1986: U.S. Environmental Protection Agency, EPA-440/5-84-002.

1989, Guidelines for the preparation of the 1990 State water quality assessment (section 305(b)): Washington, D.C., Office of Water.

1993, Preventing waterborne disease-A focus on EPA's research: U.S. Environmental Protection Agency, EPA-640/K-93/001.

1996a, Safe drinking water act amendments of 1996-General guide to provisions: U.S.

Environmental Protection Agency, Office of Water, EPA-810-S-96-001, 20 p.

1996b, Information Collection Rule-Summary for the public: U.S. Environmental Protection Agency, Office of Water, EPA 811-F-96-001, 3 p.

1996c, National primary drinking water regulations-Monitoring requirements for public drinking water supplies: Federal Register 40 CFR, part 141, v. 61, no. 94 , p. 24353-24388.

1998, National primary drinking water regulations-Disinfectants and disinfection byproducts-Final rule: Federal Register 40 CFR, parts 9, 141 , and 142 , v. 63 , no. 241, p. 69389-69476.
1999, Information Collection Rule, Office of Ground Water and Drinking Water: accessed December 6, 1999, at URL http:// www.epa.gov/ OGWDW/icr.html.

2000, Envirofacts Warehouse-Information Collection Rule, query form for the State of Alabama: accessed September 15, 2000, at URL http://www.epa.gov/enviro/html/icr/state/AL.html.

Vollenweider, R.A., 1968, Scientific fundamentals of the eutrophication of lakes and flowing waters, with particular reference to nitrogen and phosphorus as factors in eutrophication: Paris, France, OECD Technical Report DA5/C51/68.27, 159 p.

1969, Possibilities and limits of elementary models concerning the budget of substances in lakes: Arch. Hydrobiol., v. 66, p. 1-36.

1975, Input-output models with special reference to the phosphorus loading concept in limnology:

Schweizische Zeitshrift fuer Hydrologie, v. 37, p. 53-84.

1976, Advances in defining critical loading levels for phosphorus in lake eutrophication: Mem. Ist. Ital. Idrobiol, v. 33, p. 53-83.

Vollenweider, R.A., and Kerekes, J., 1980, The loading concept as basis for controlling

eutrophication-Philosophy and preliminary results of the OECD program on eutrophication: Progress in Water Technology, v. 12, p. 5-38.

Wetzel, R.G., 1983, Limnology (2d ed.): Fort Worth, Tex., Saunders College Publishing, $766 \mathrm{p}$.

Wilde, F.D., and Radtke, D.B., 1998, eds., Field measurements-National field manual for the collection of water-quality data: U.S. Geological Survey Techniques of Water-Resources Investigations, book 9, chap. A6.

Wilde, F.D., Radtke, D.B., Gibs, J., and Iwatsubo, R.T., 1998, Preparations for water sampling-National field manual for the collection of water-quality data: U.S. Geological Survey Techniques of Water-Resources Investigations, book 9, chap. A1.

1999a, Collection of water samples-National field manual for the collection of water-quality data: U.S. Geological Survey Techniques of Water-Resources Investigations, book 9, chap. A4.

1999b, Processing of water samples-National field manual for the collection of water-quality data: U.S. Geological Survey Techniques of Water-Resources Investigations, book 9, chap. A5.

Yeasted, J.G., and Moret, F.M.M., 1978, Empirical insights into lake response to nutrient loadings, with application to models of phosphorus in lakes: Environmental Science and Technology, v. 12, no. 2, p. 195-201. 


\section{Appendixes}




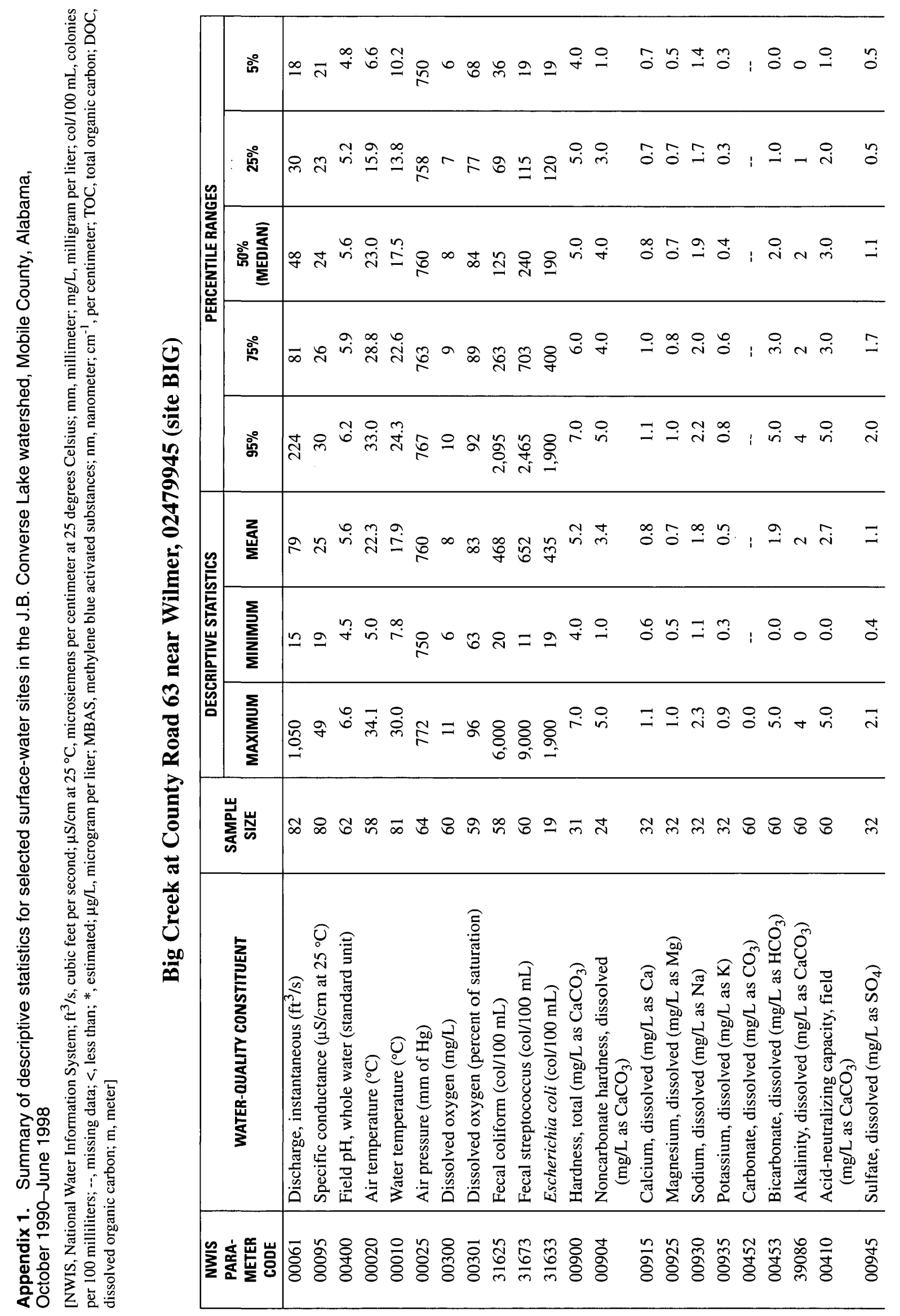




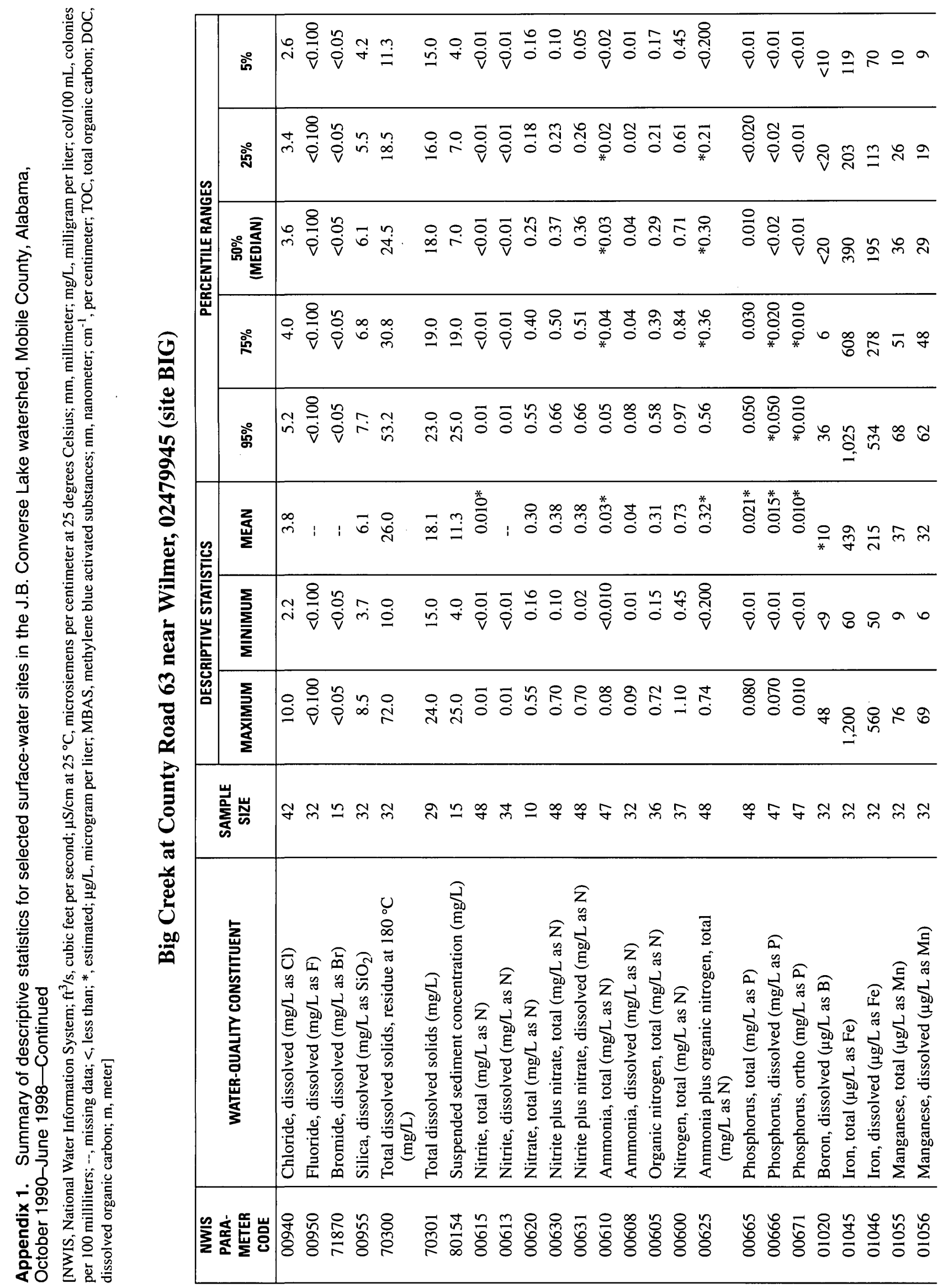




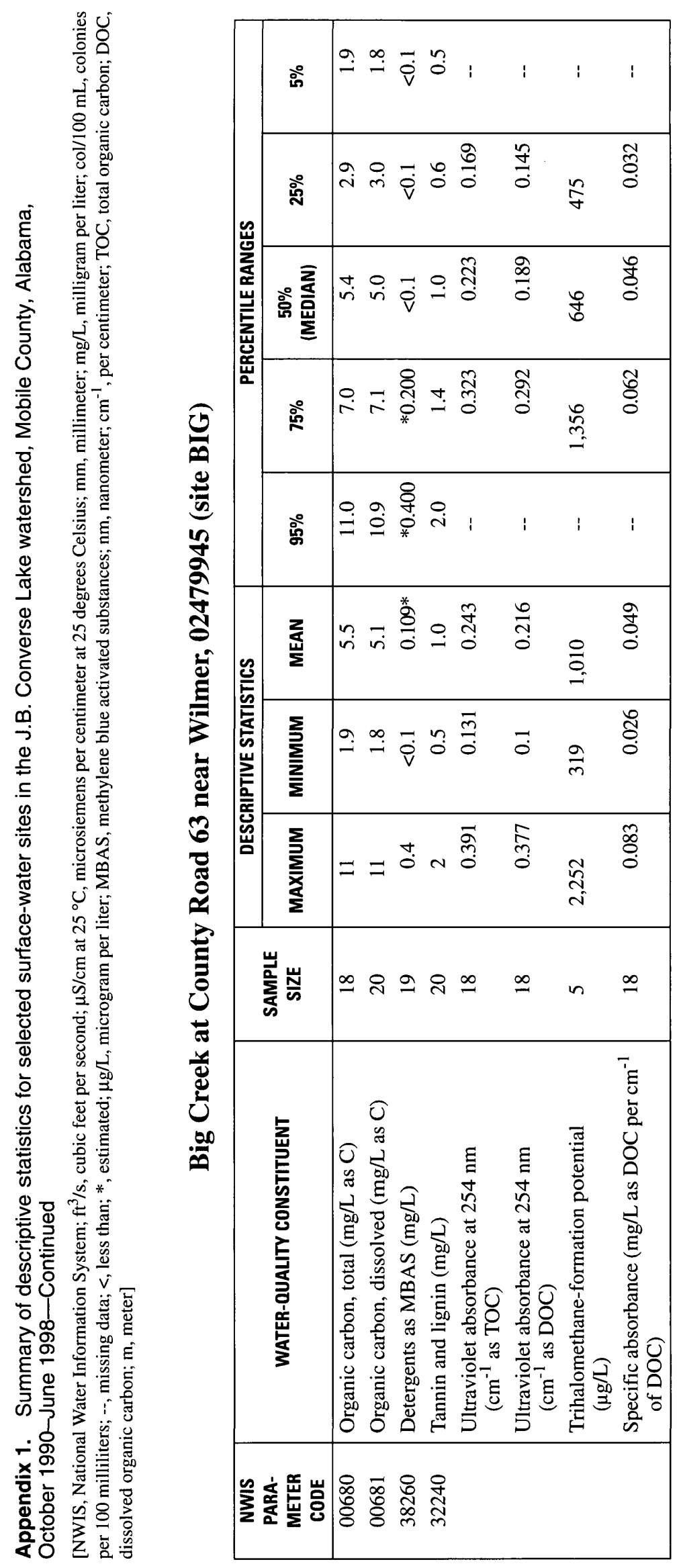




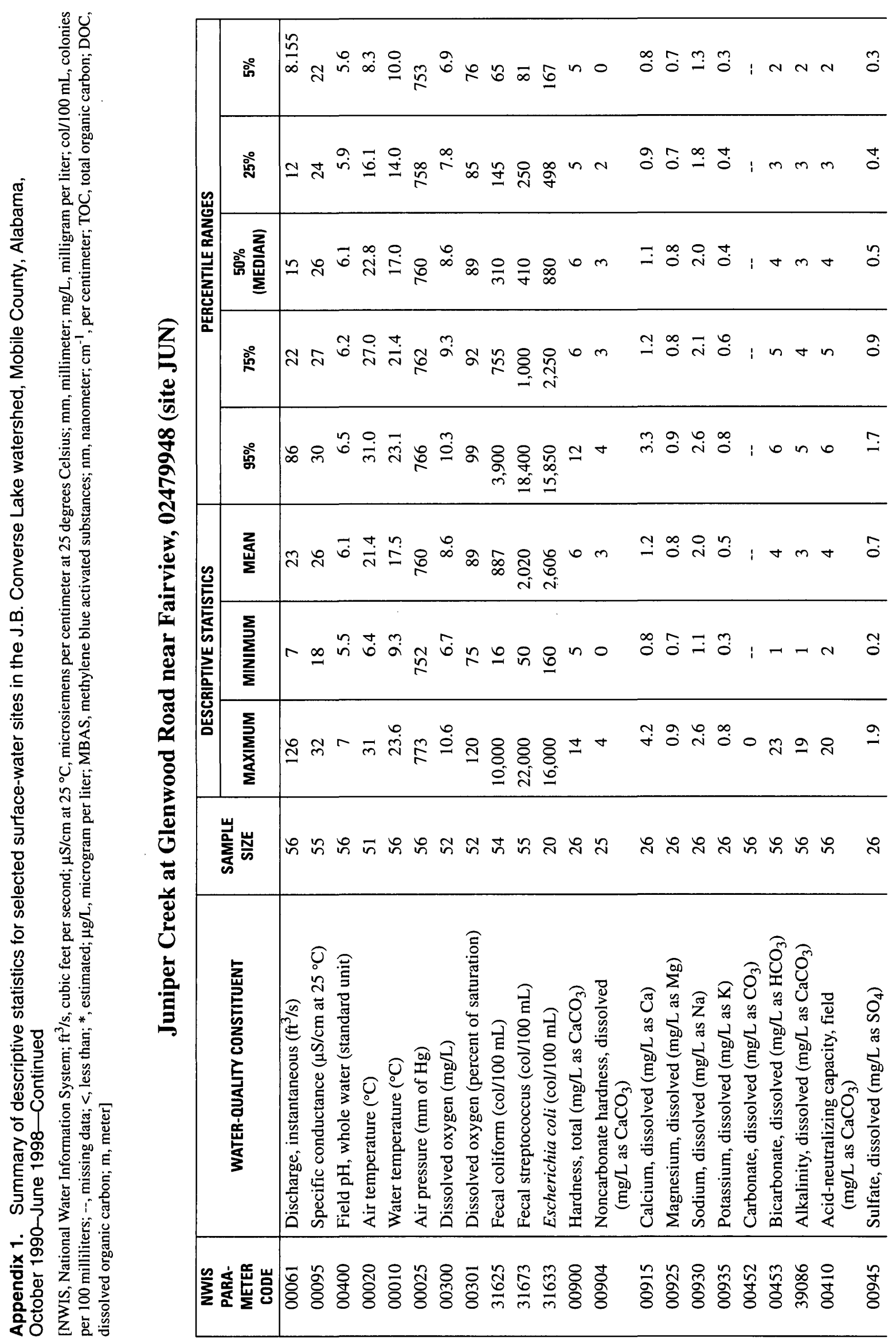




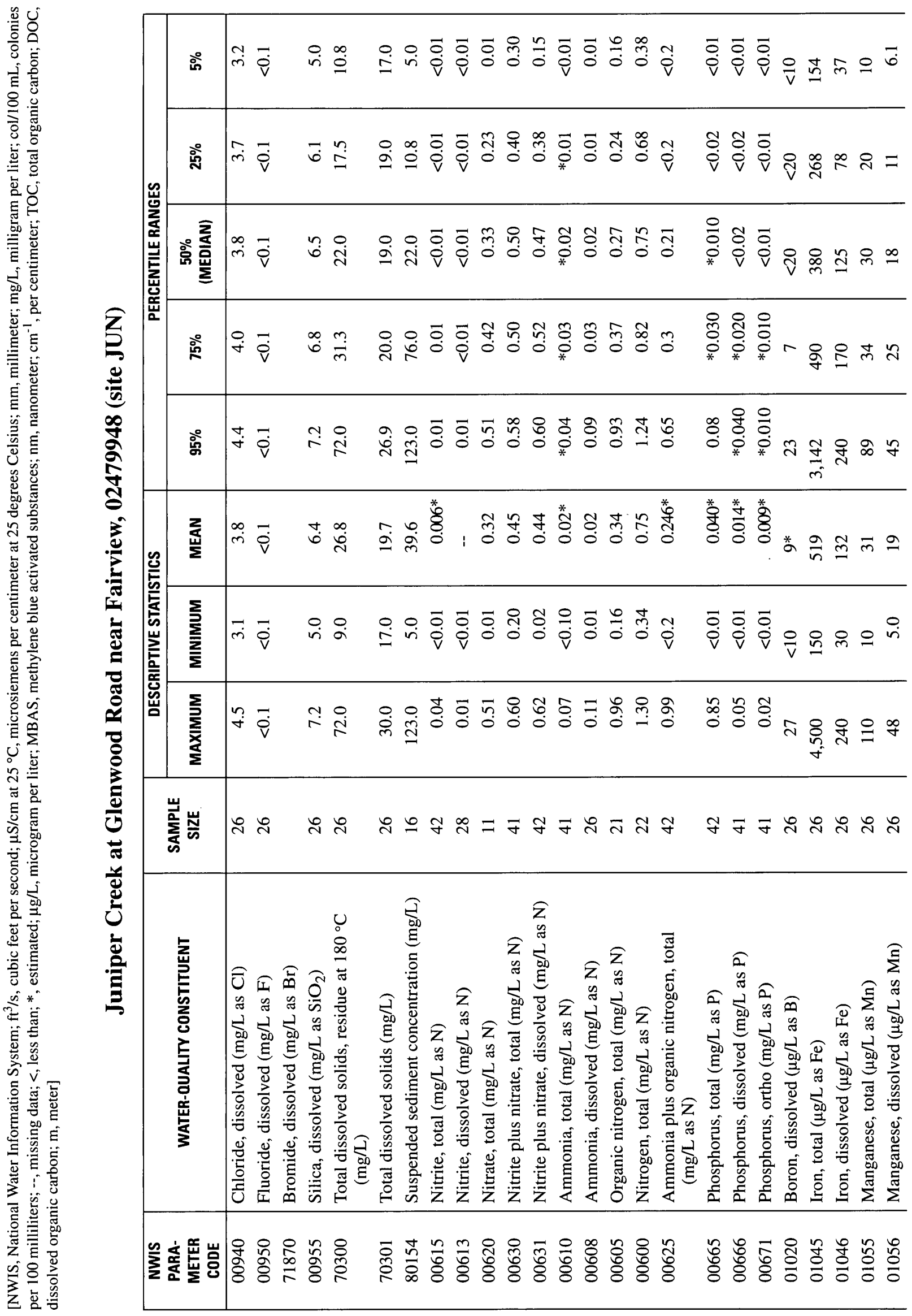




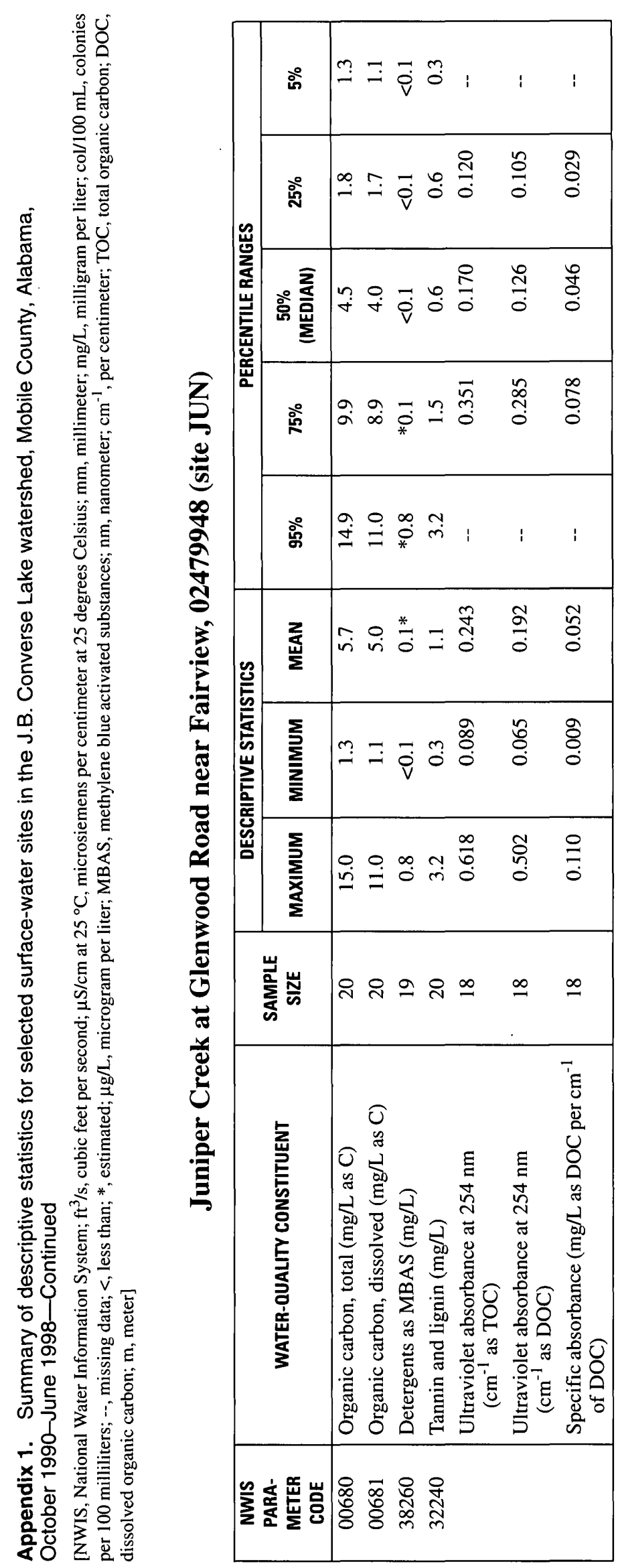




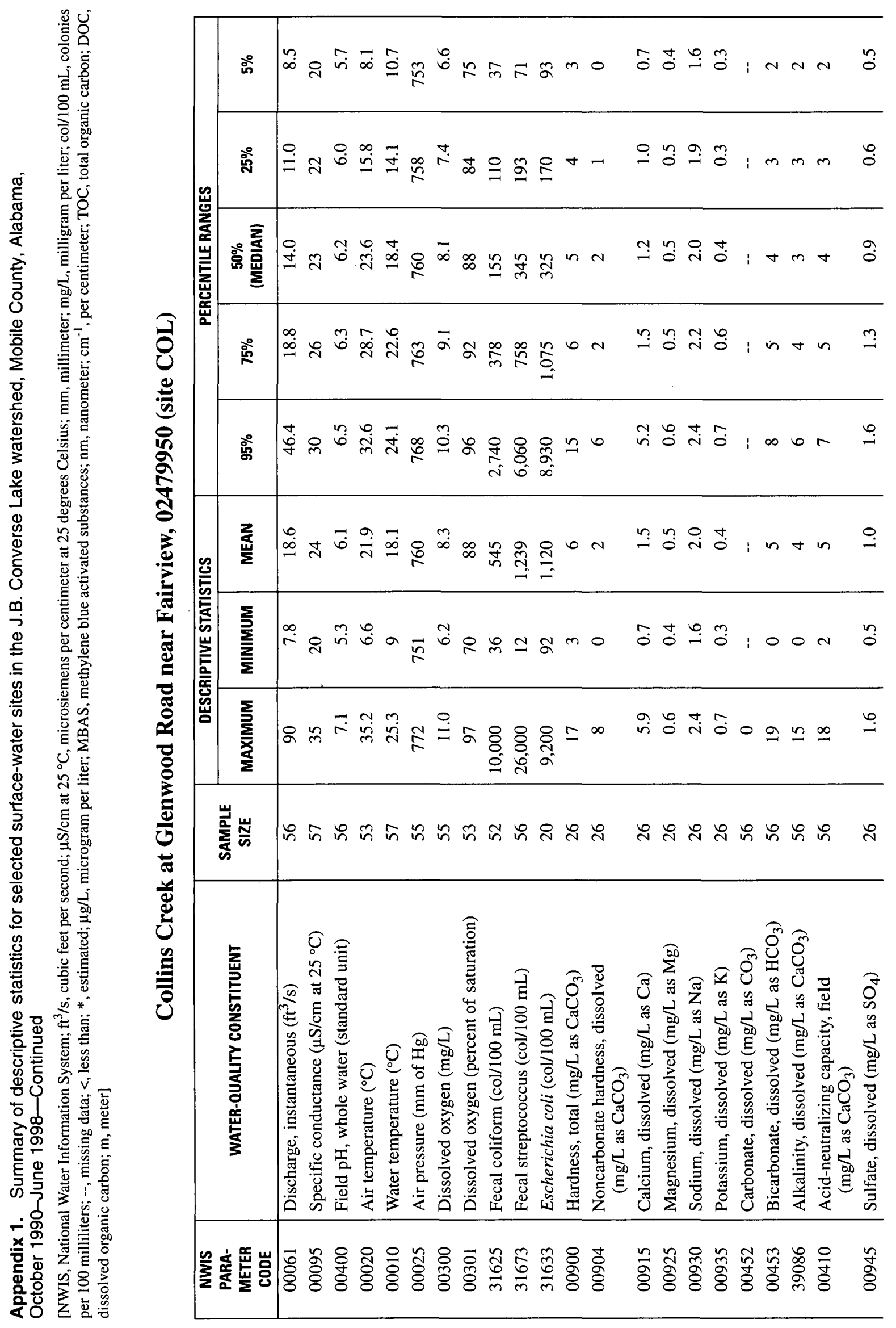




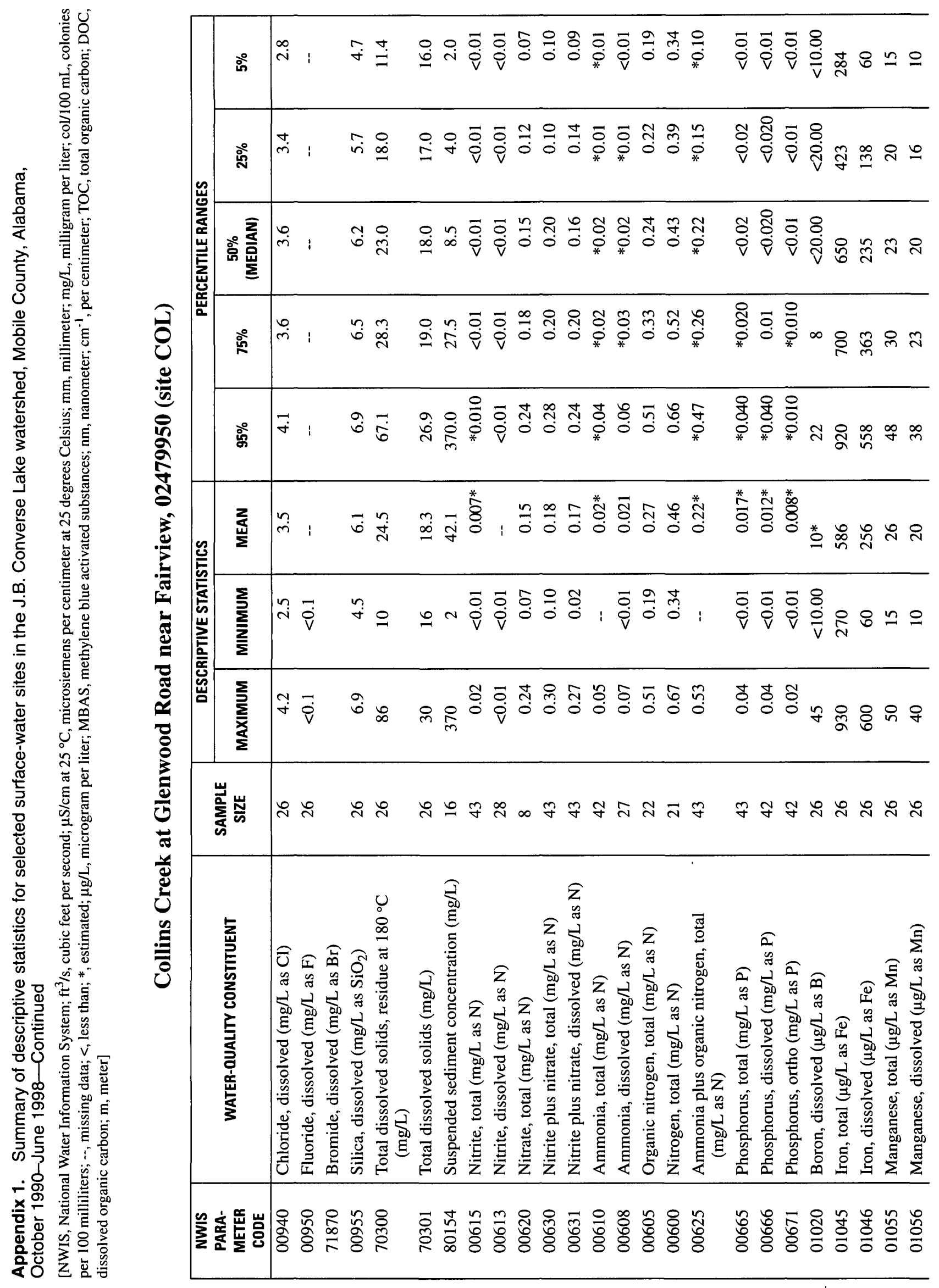




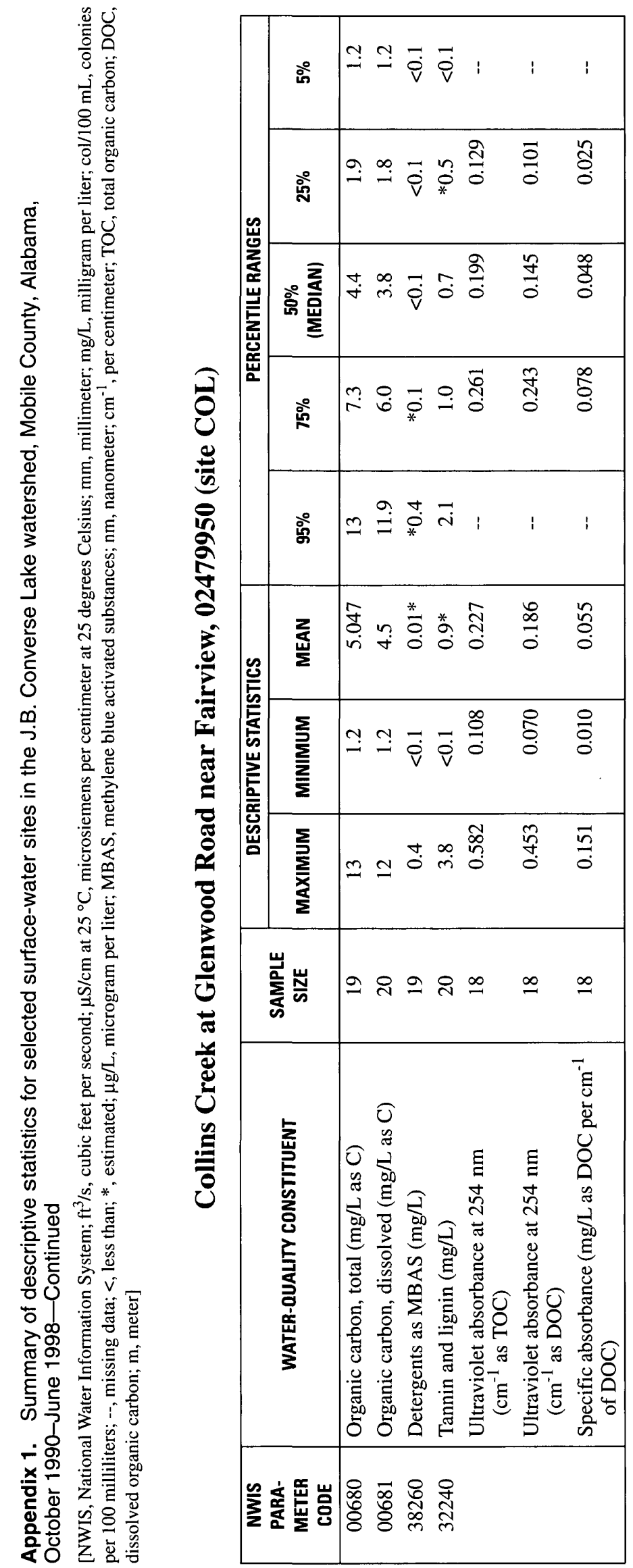




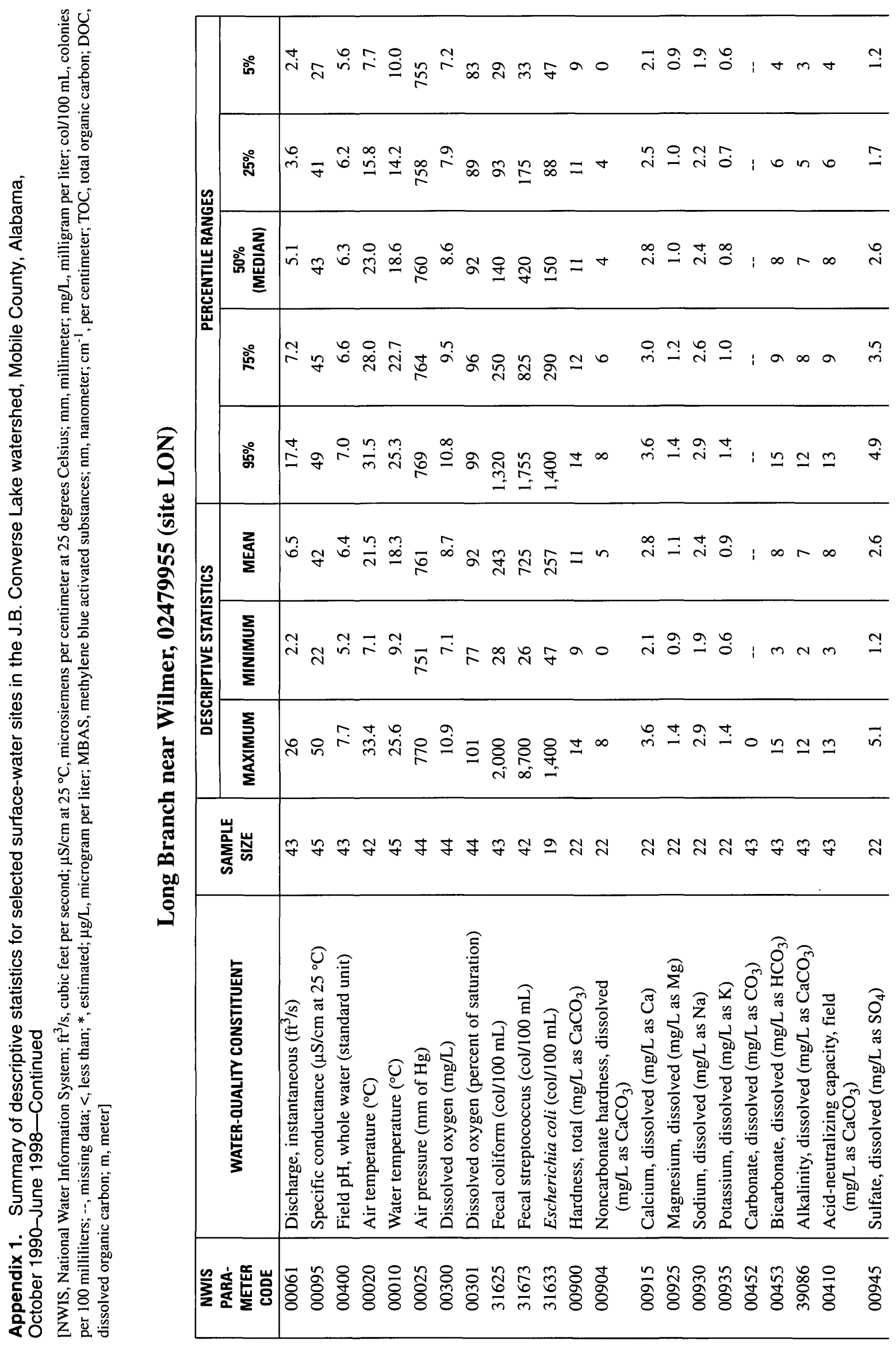




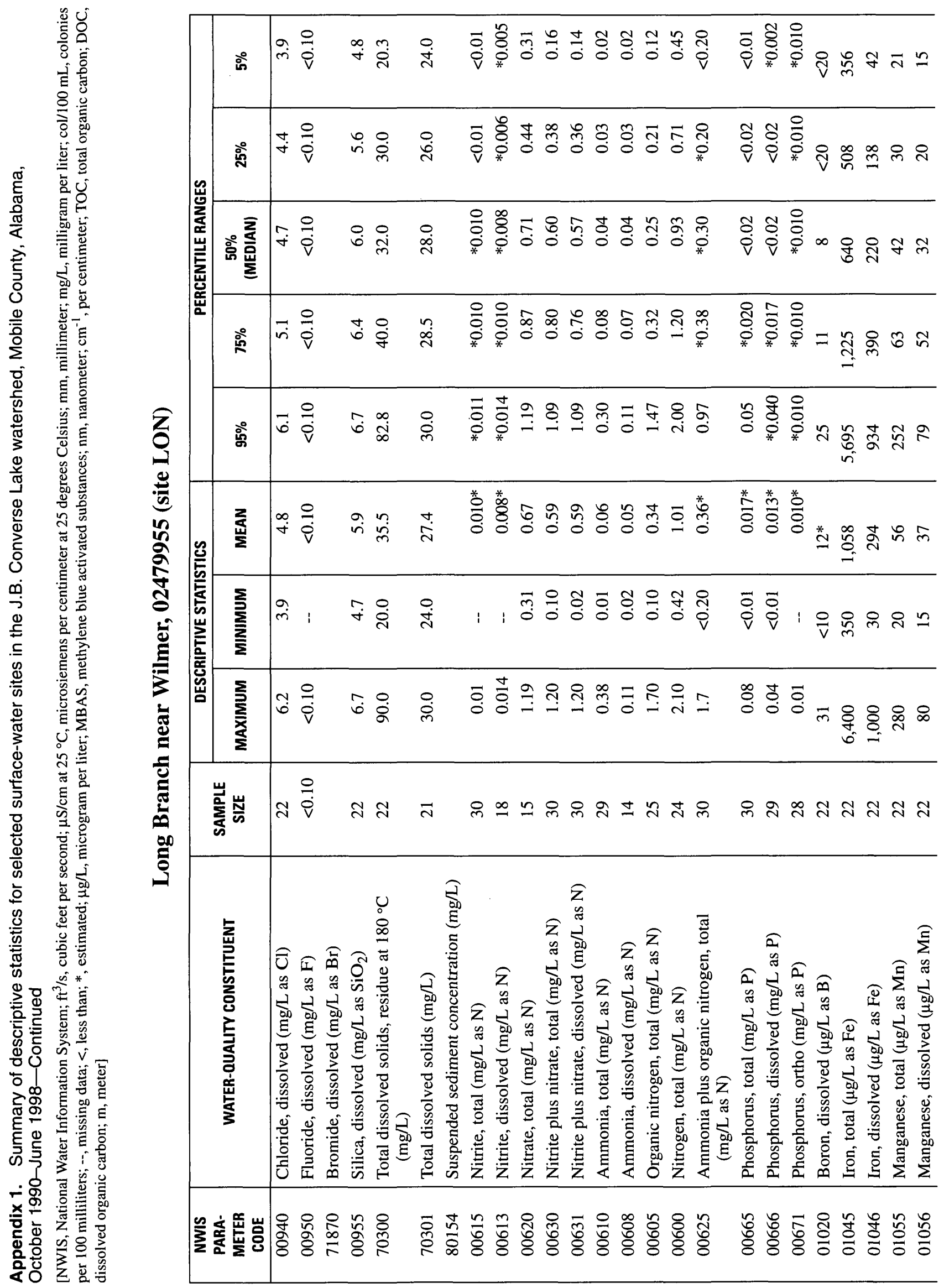




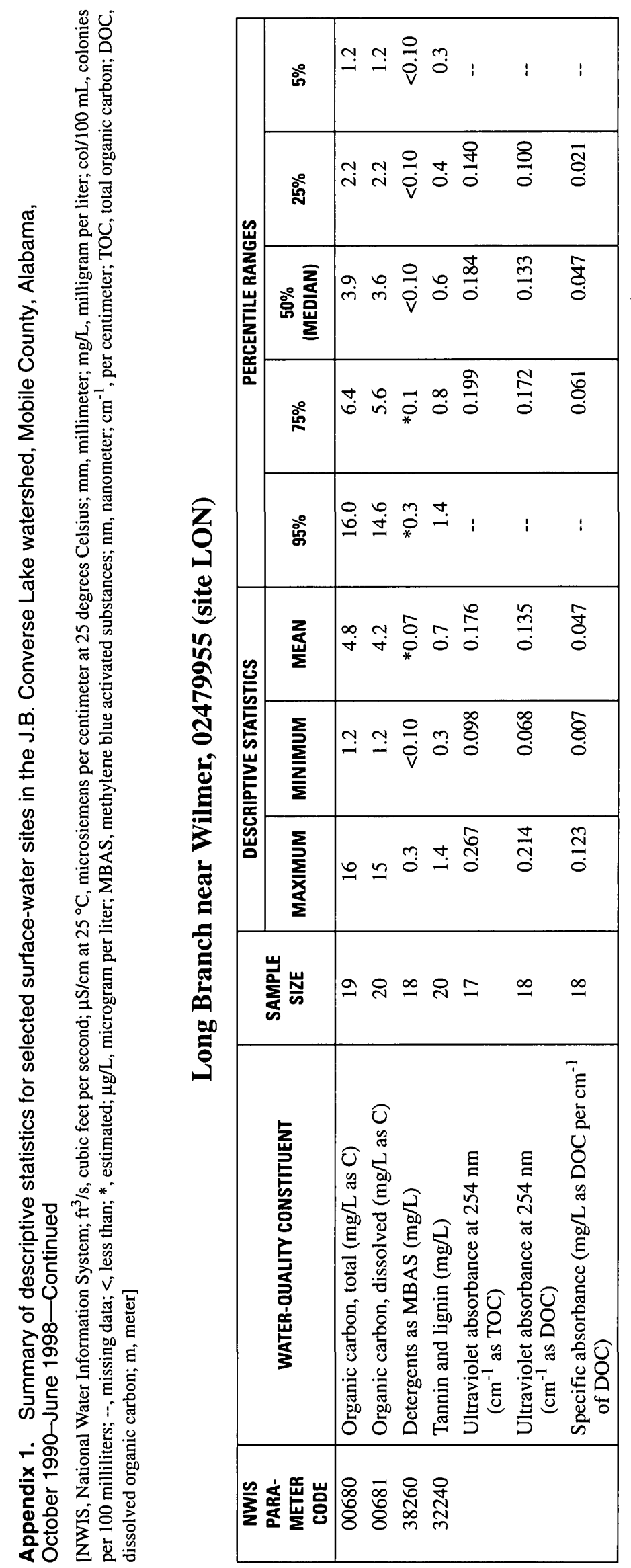




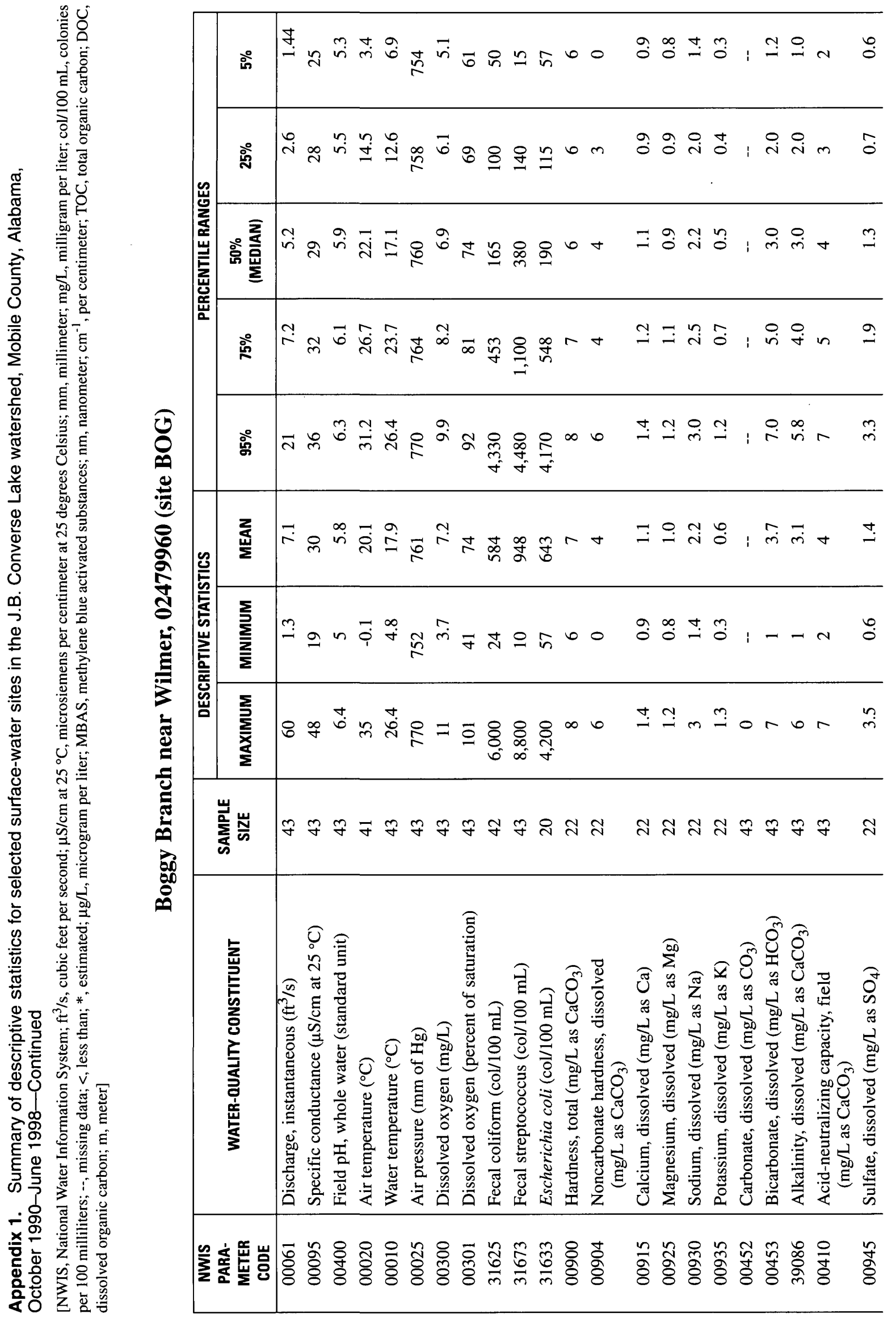




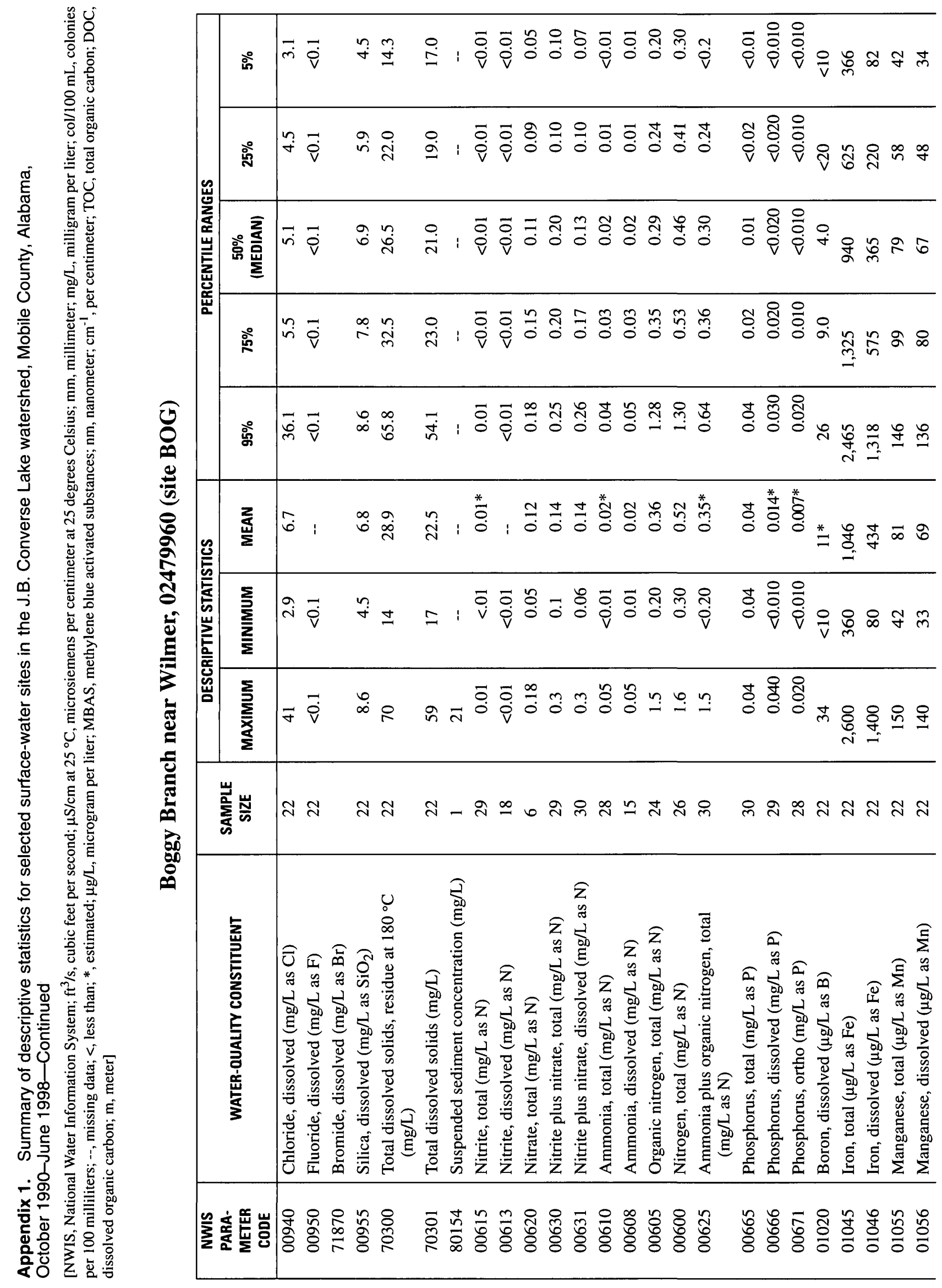




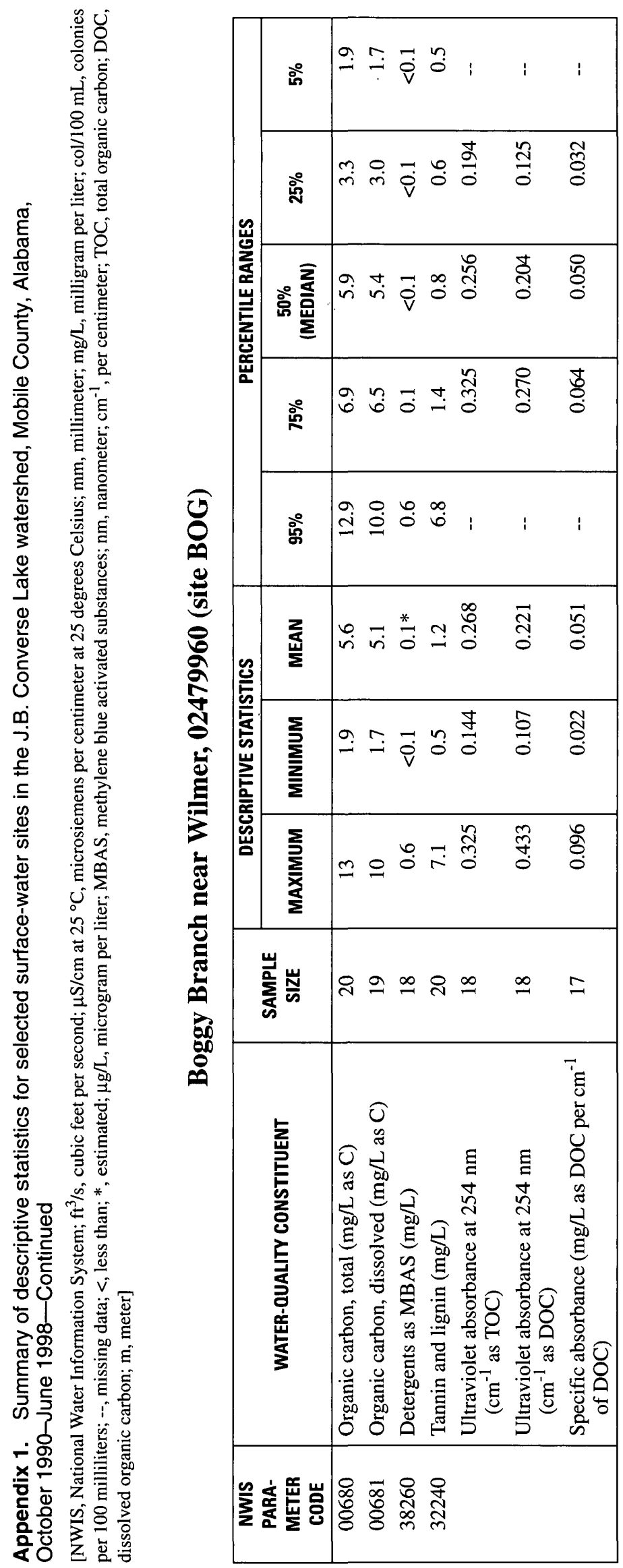




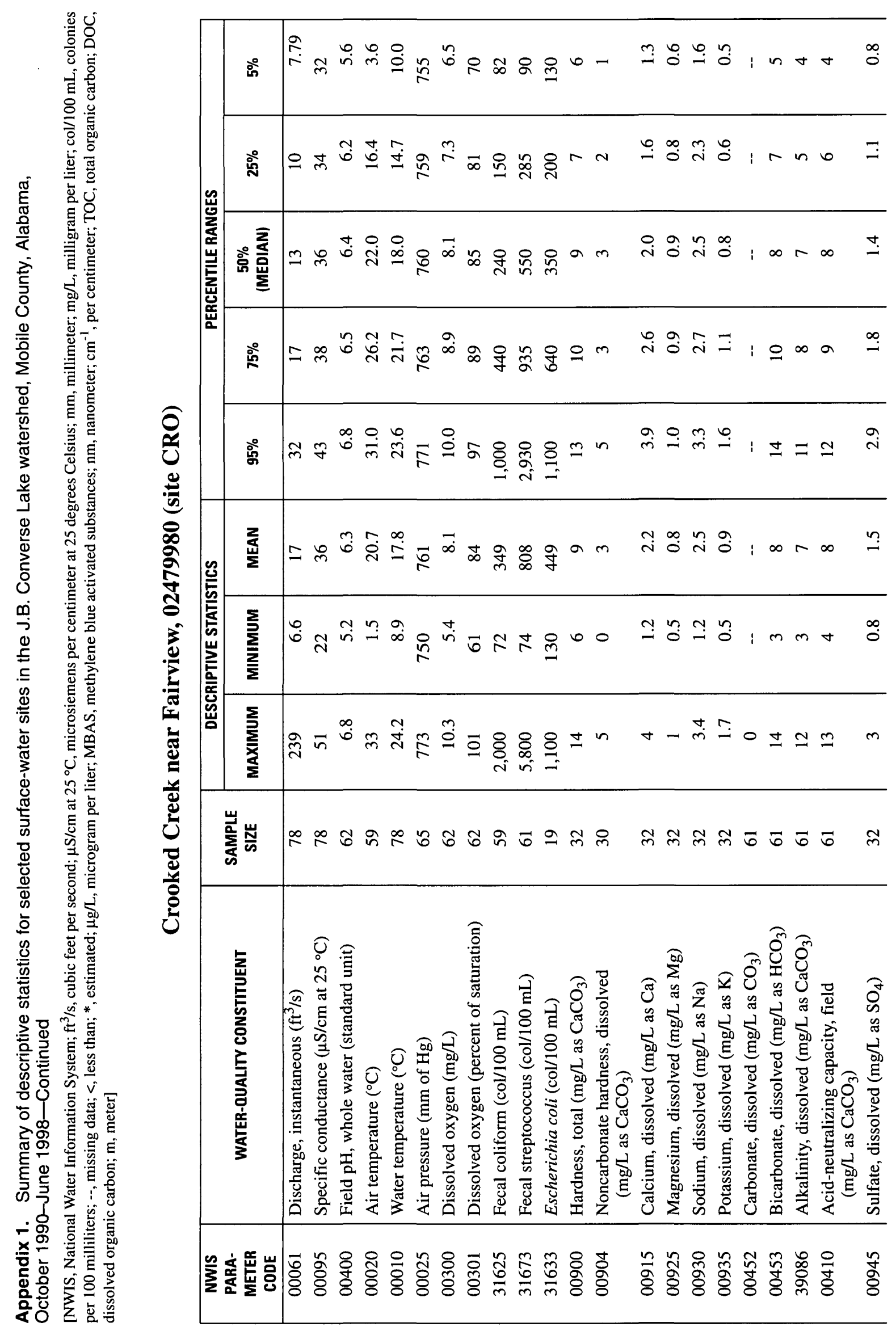




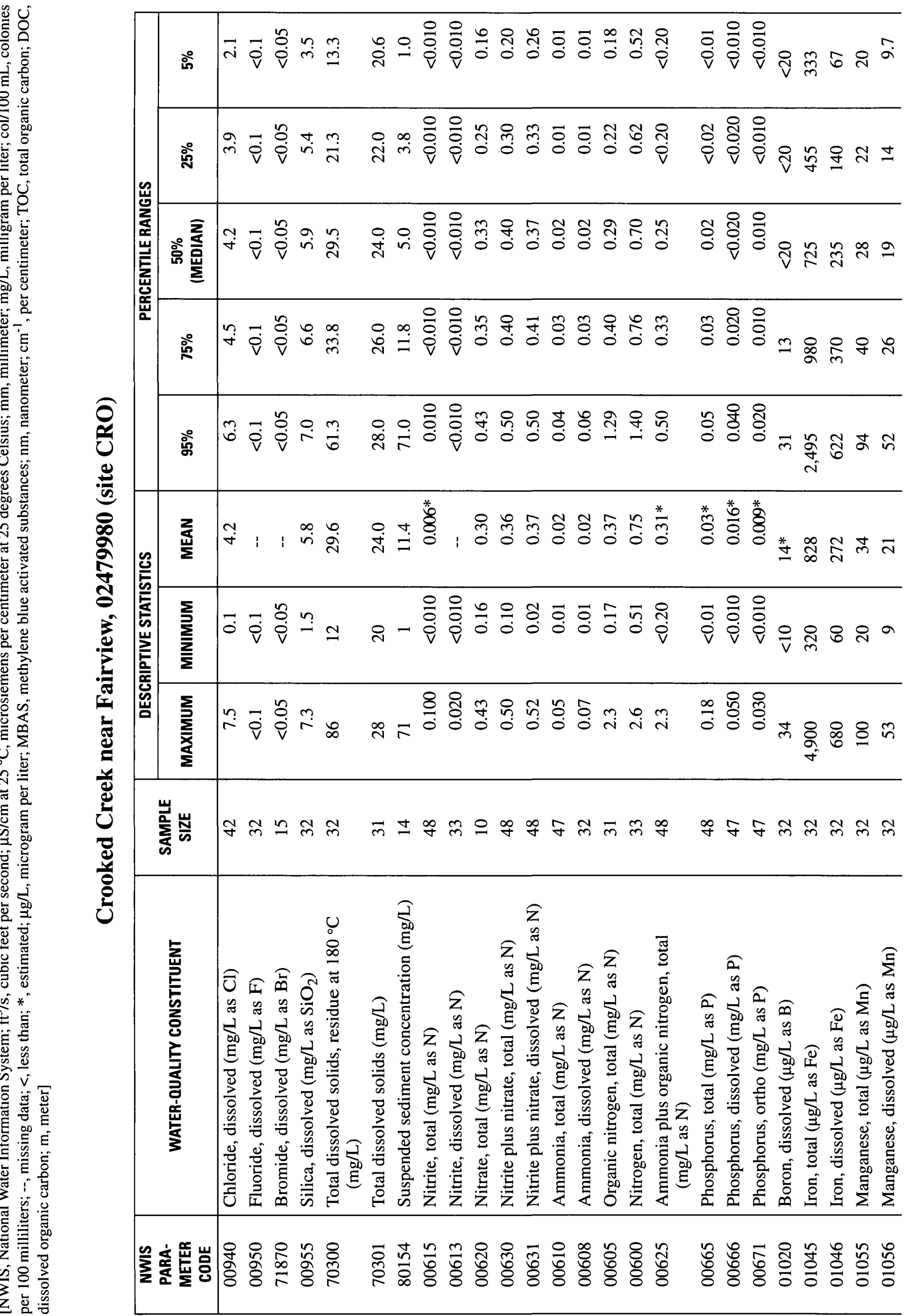




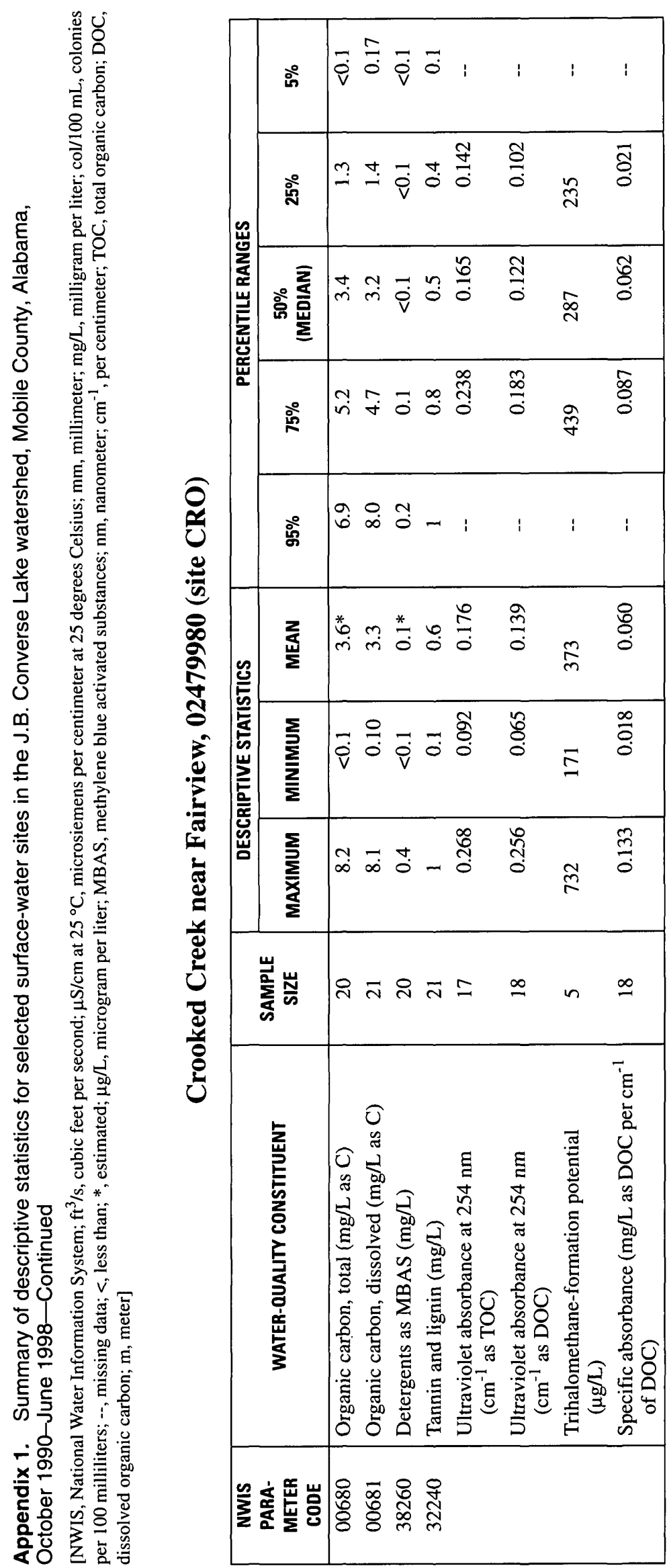




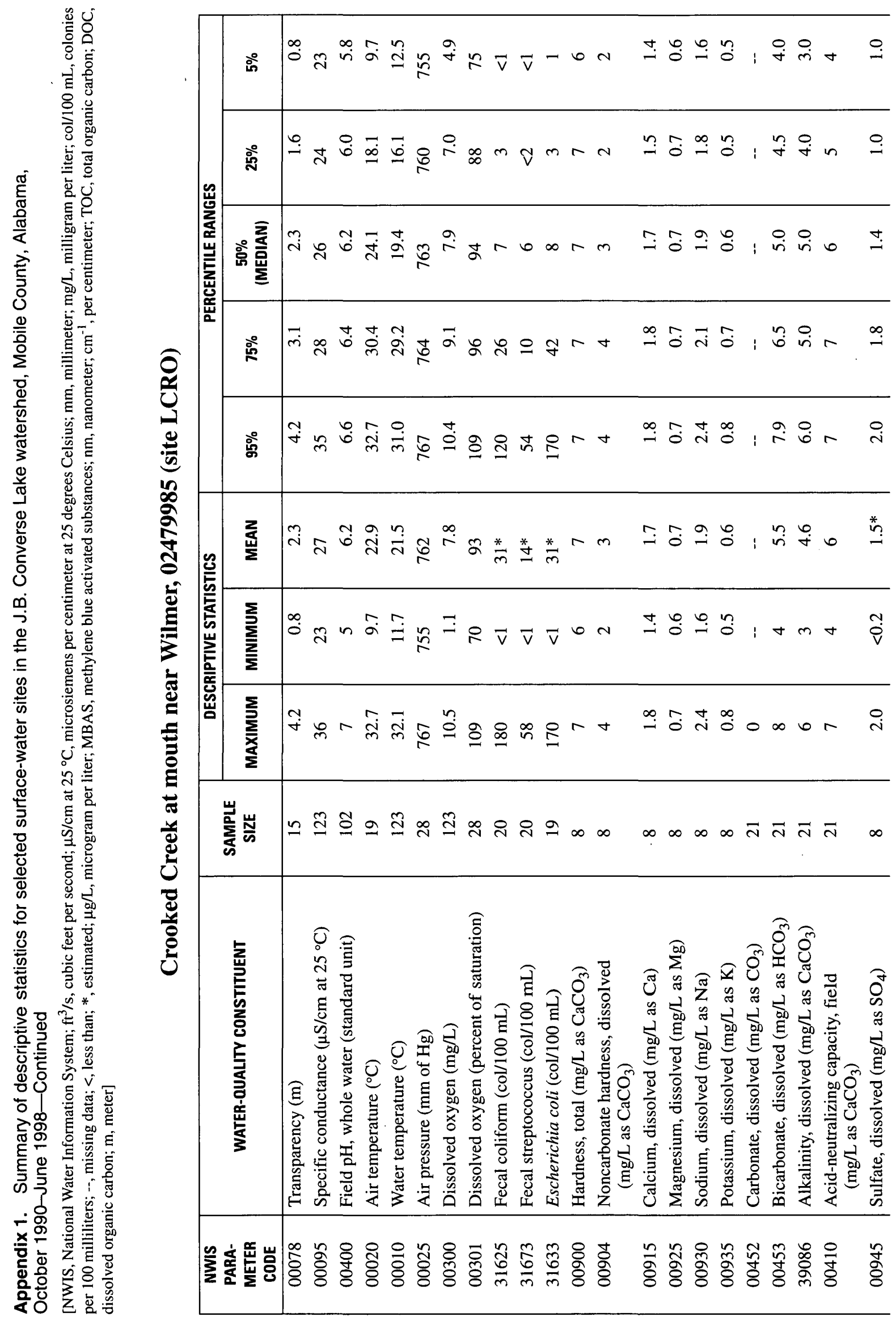




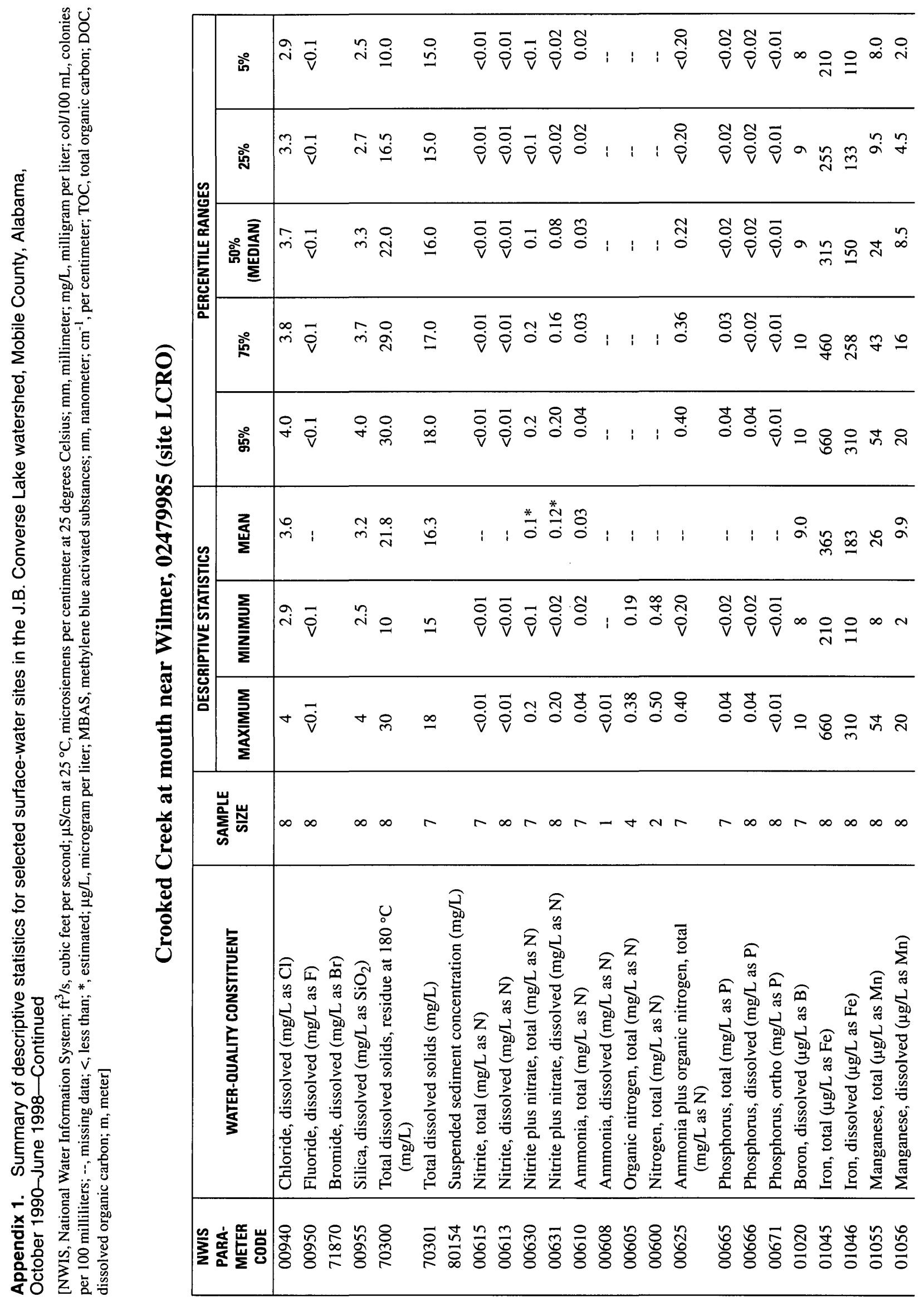




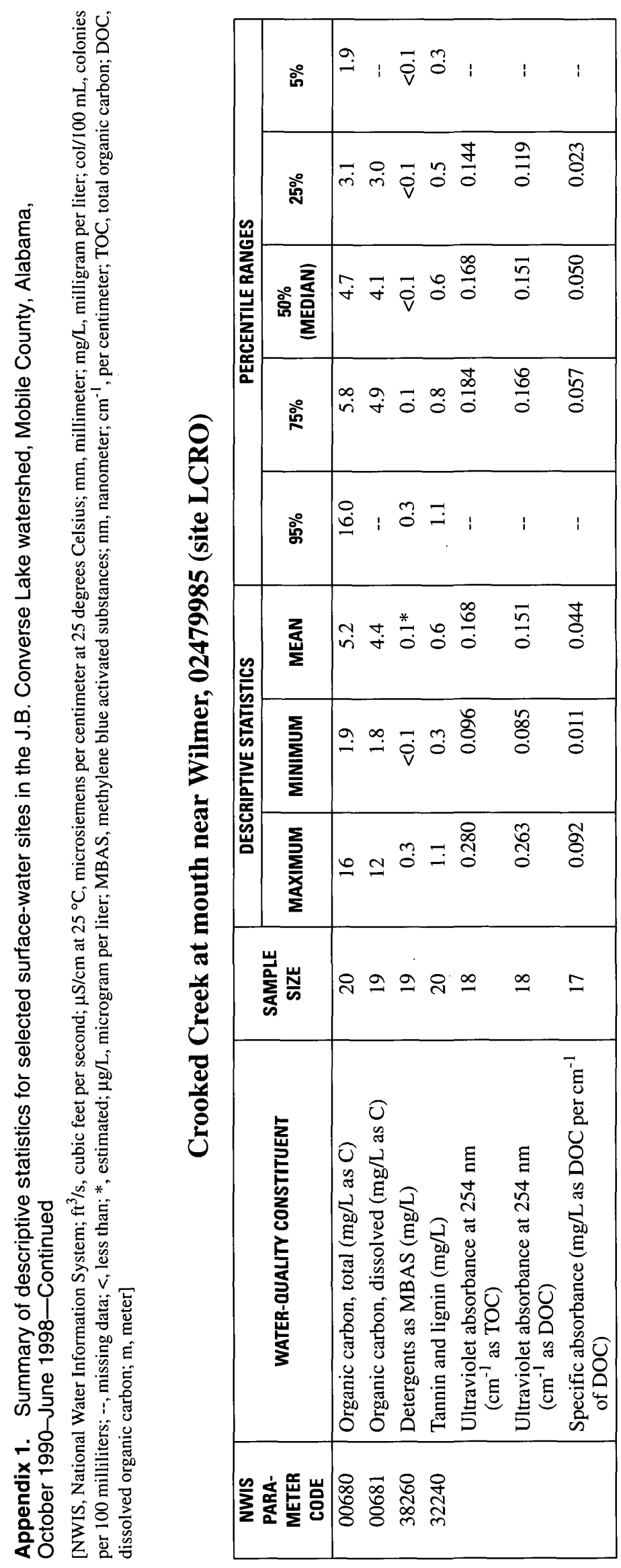




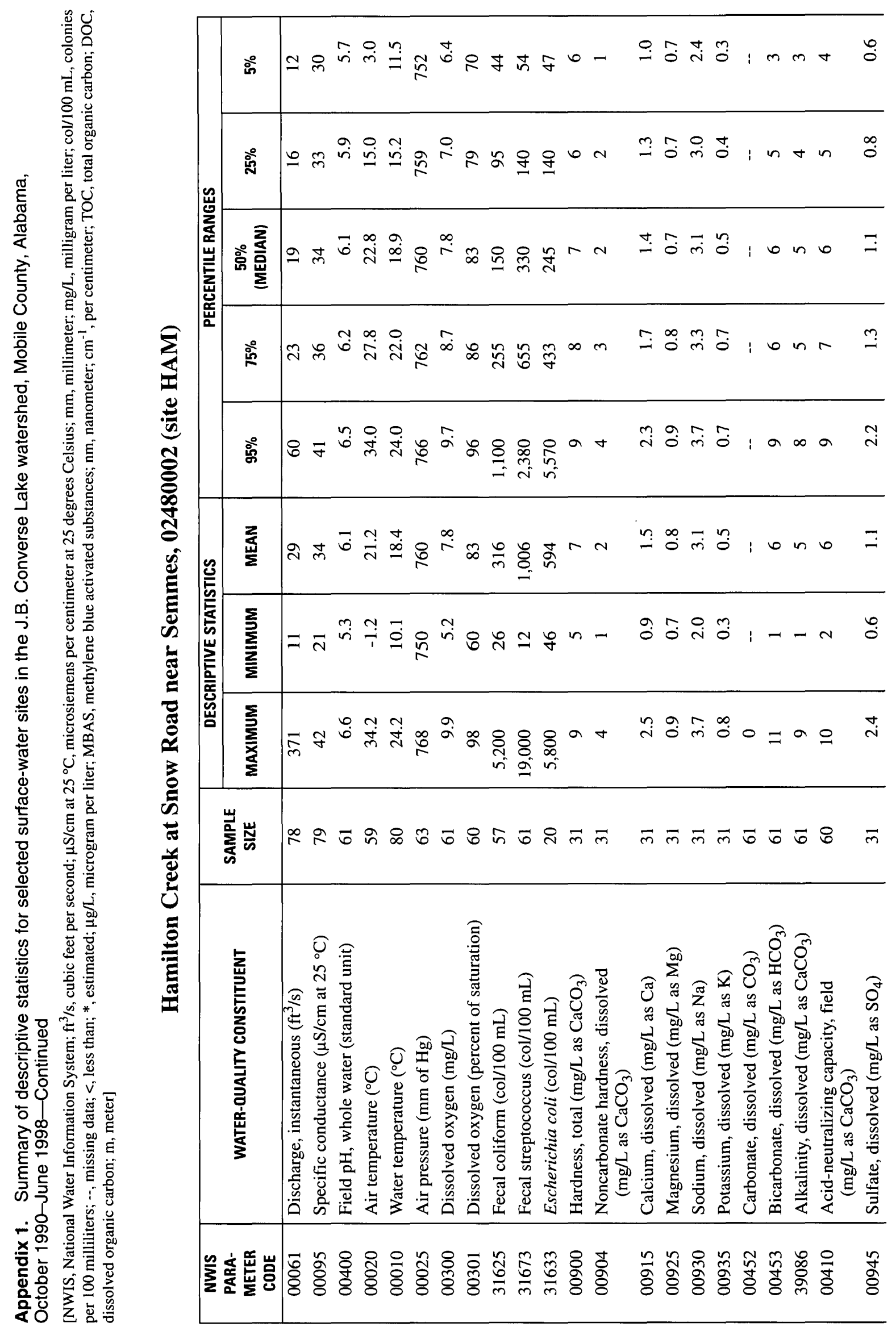




\begin{tabular}{|c|c|c|c|}
\hline 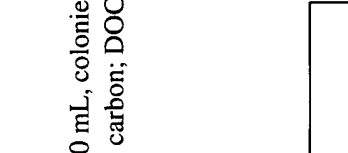 & $\stackrel{\circ}{\circ}$ & F & is \\
\hline 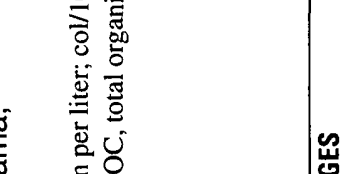 & 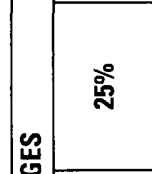 & 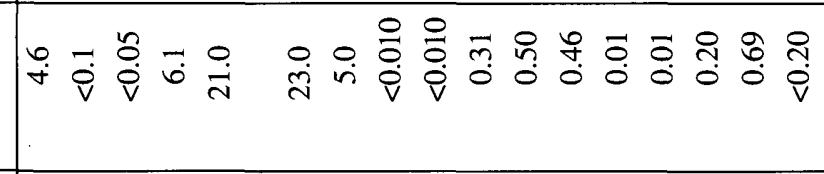 & कृष \\
\hline 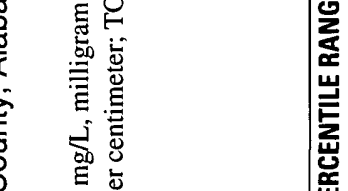 & 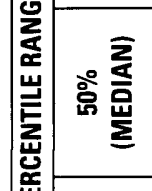 & 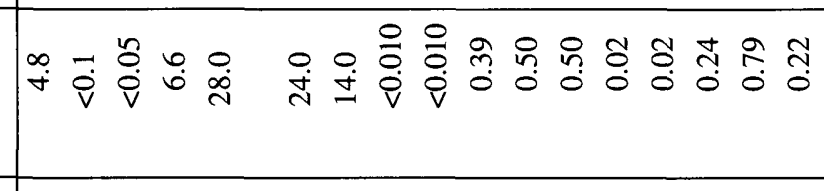 & $\stackrel{8}{\circ}$ \\
\hline 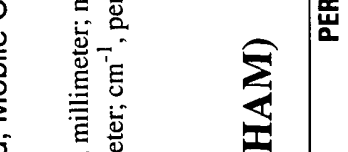 & 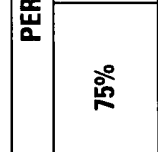 & 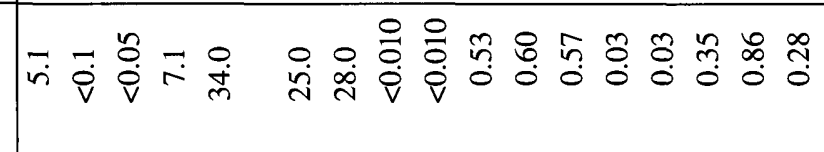 & : \\
\hline 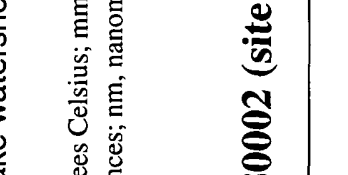 & 今. & 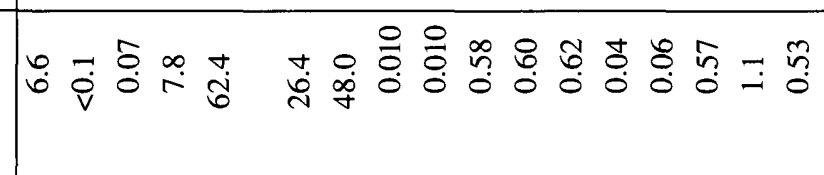 & 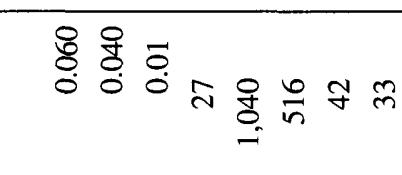 \\
\hline है. & $\underset{\underline{\underline{W}}}{z_{2}}$ & 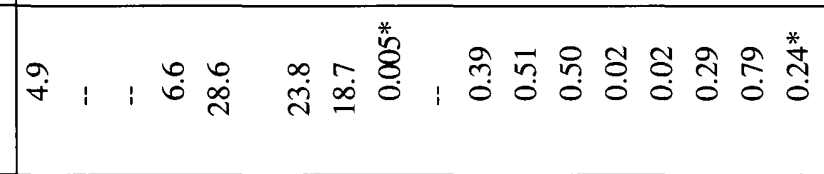 & 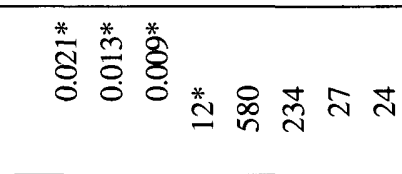 \\
\hline 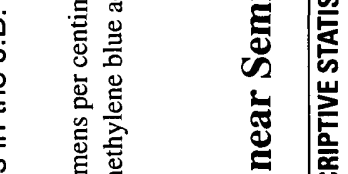 & 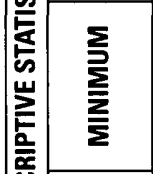 & 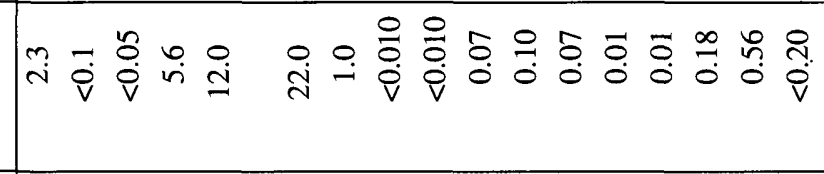 & 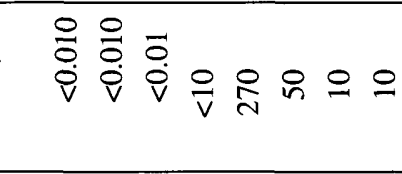 \\
\hline 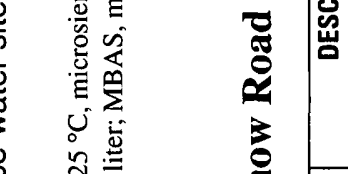 & 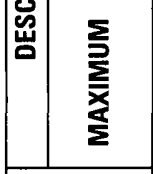 & ఇ: & 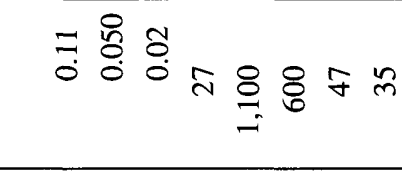 \\
\hline 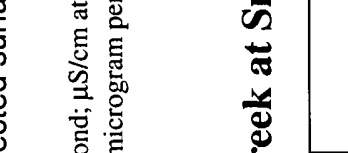 & 岕嵌 & 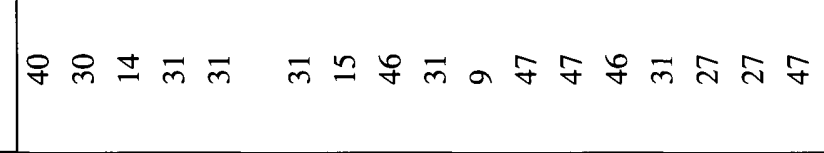 & 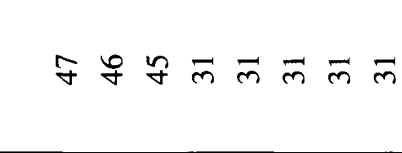 \\
\hline 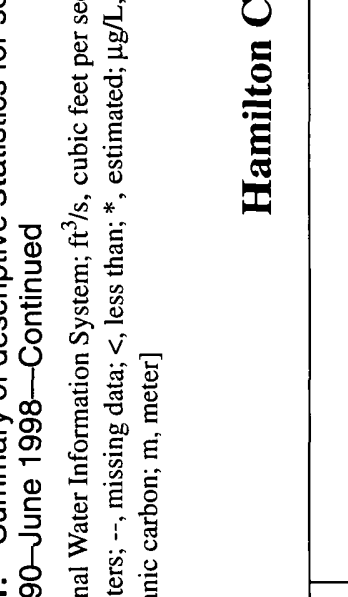 & 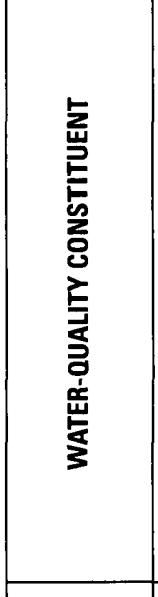 & 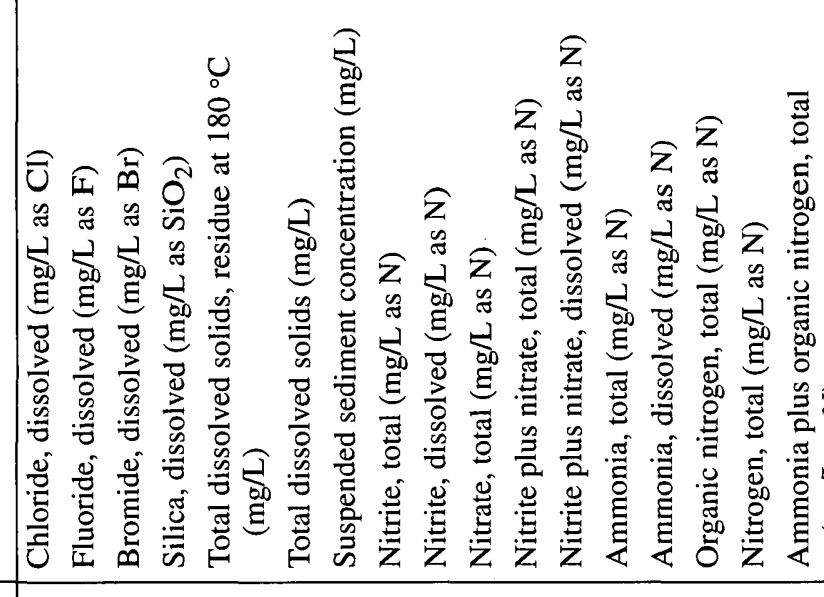 & 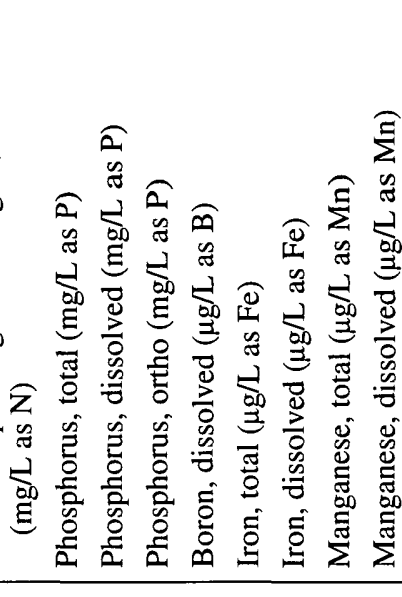 \\
\hline & & & \\
\hline
\end{tabular}




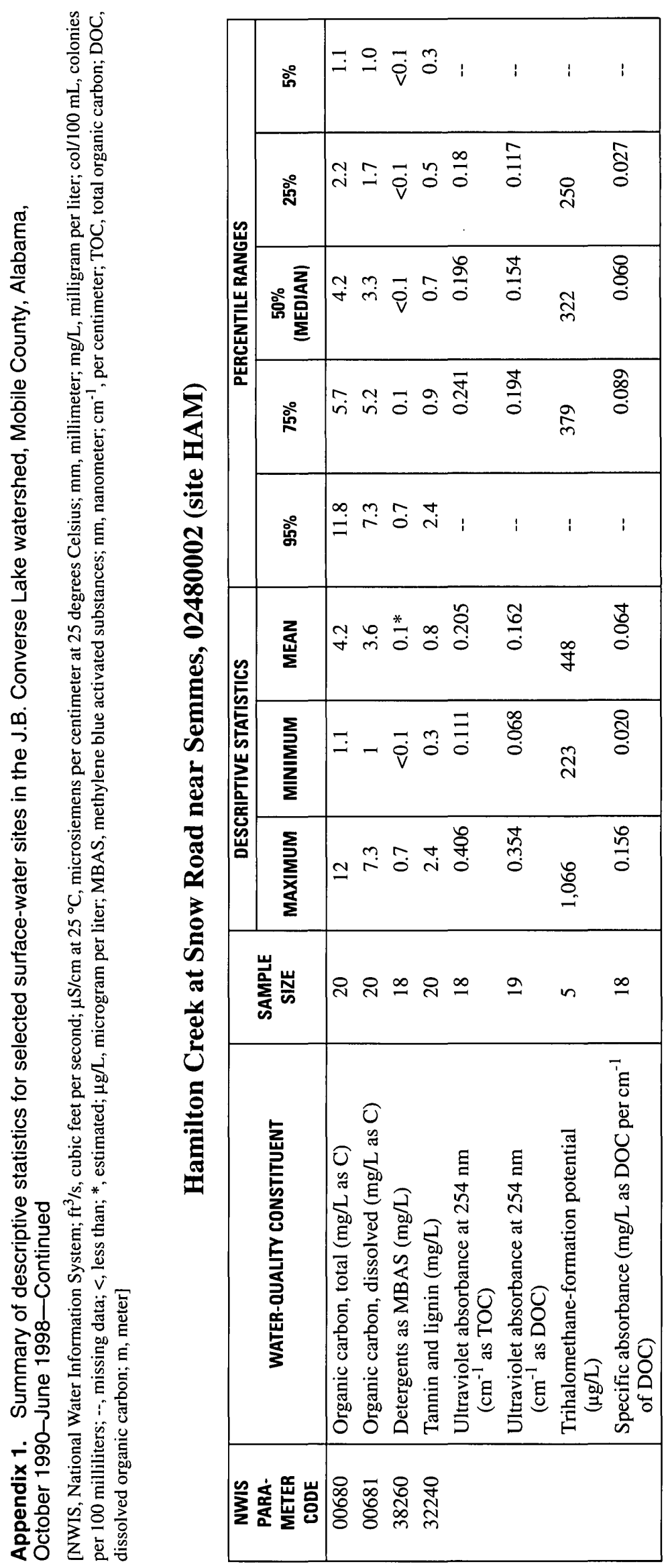




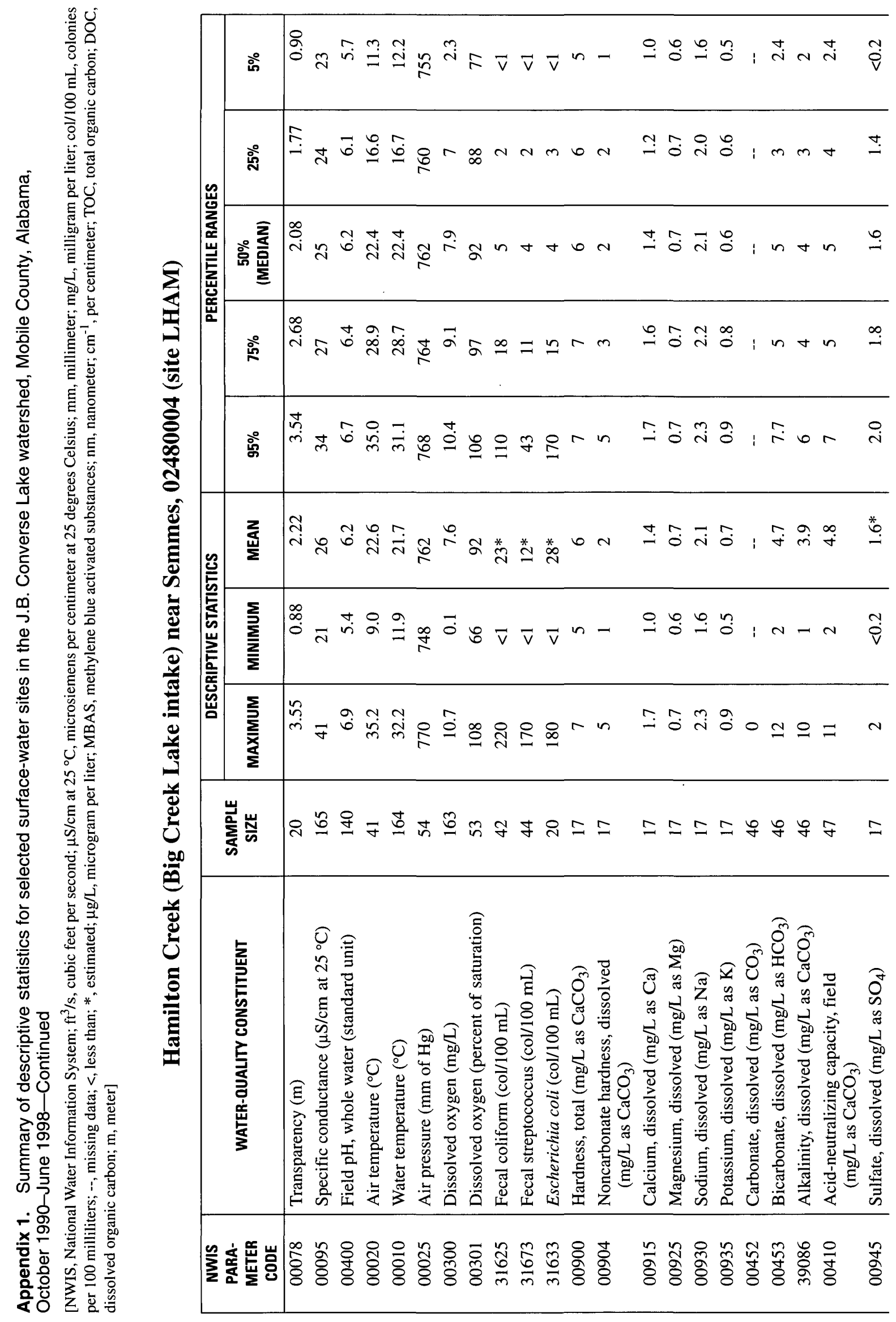




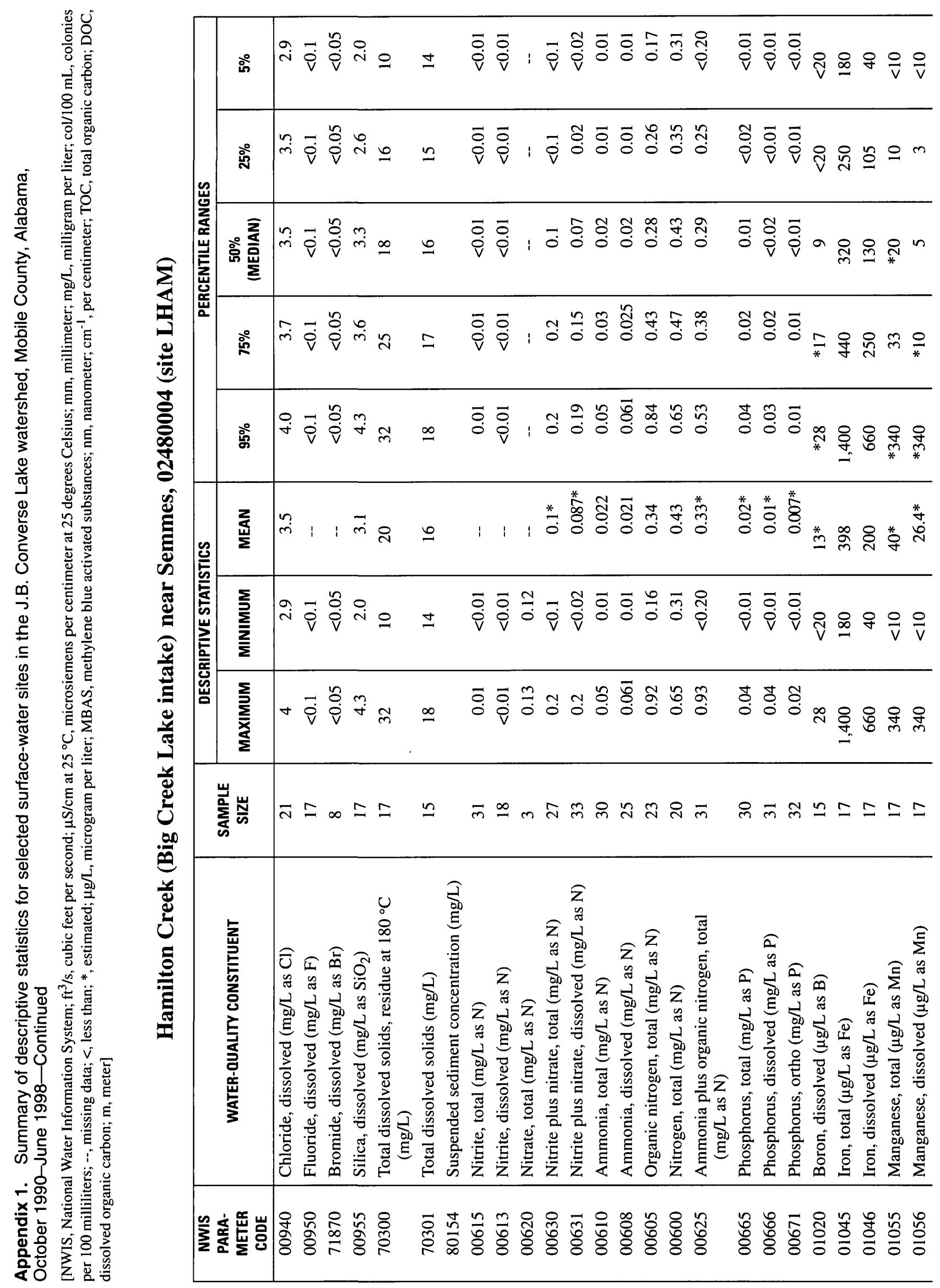




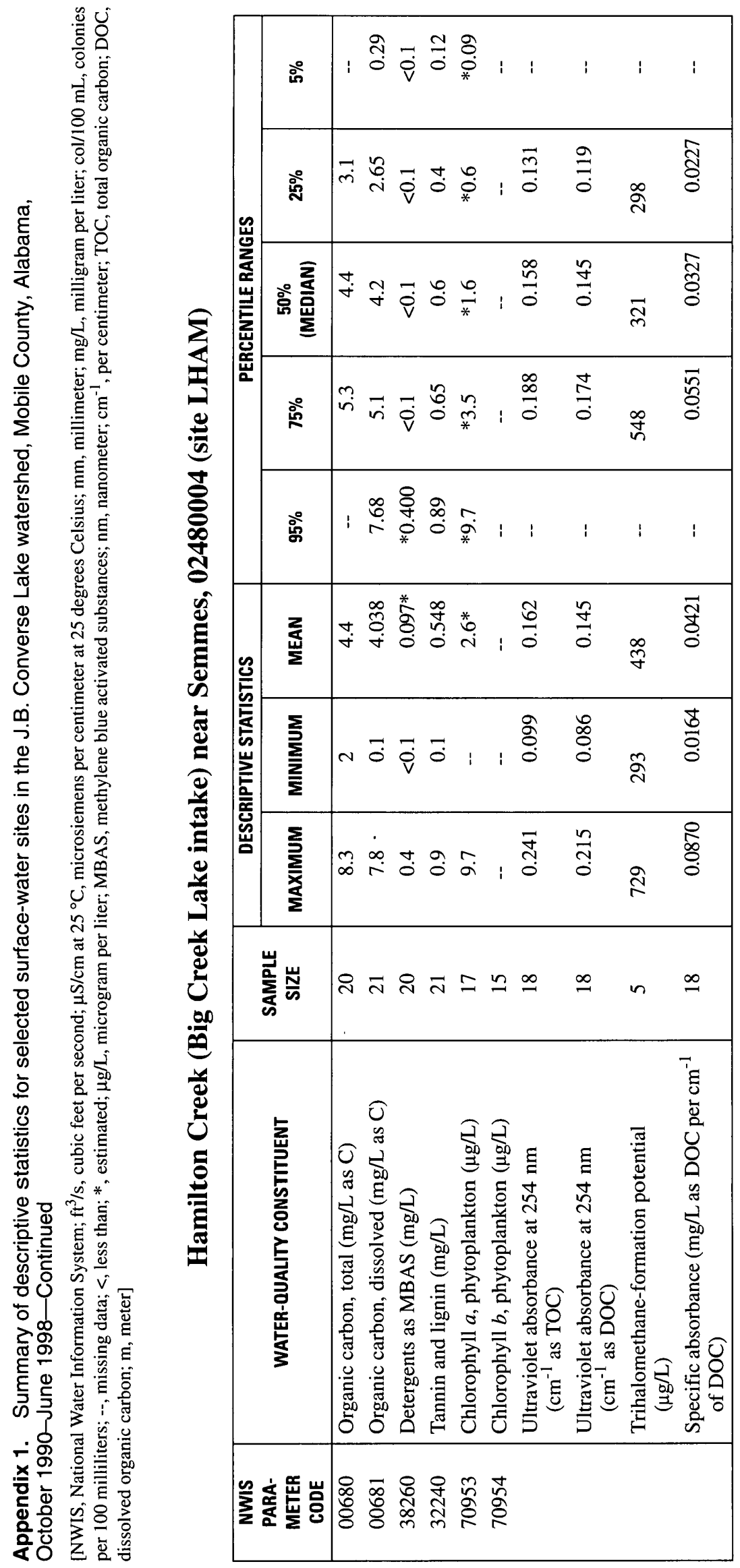


Appendix 2. Monthly mean load tables for selected surface-water sites in the J.B. Converse Lake watershed, Mobile County, Alabama, 1990-98

[kg/d, kilograms per day]

Big Creek at County Road 63 near Wilmer, 02479945 (site BIG)

Total nitrogen

\begin{tabular}{|c|c|c|c|c|c|c|c|}
\hline Month & $\begin{array}{c}\text { Daily mean } \\
\text { constituent } \\
\text { discharge } \\
(\mathrm{kg} / \mathrm{d})\end{array}$ & $\begin{array}{c}\text { Standard } \\
\text { error } \\
(\mathbf{k g} / \mathrm{d})\end{array}$ & $\begin{array}{c}\text { Standard } \\
\text { error of } \\
\text { prediction } \\
(\mathbf{k g} / \mathbf{d})\end{array}$ & Month & $\begin{array}{c}\text { Daily mean } \\
\text { constituent } \\
\text { discharge } \\
\text { (kg/d) }\end{array}$ & $\begin{array}{c}\text { Standard } \\
\text { error } \\
(\mathrm{kg} / \mathrm{d})\end{array}$ & $\begin{array}{c}\text { Standard } \\
\text { error of } \\
\text { prediction } \\
\text { (kg/d) } \\
\end{array}$ \\
\hline \multicolumn{4}{|c|}{ Water year 1991} & \multicolumn{4}{|c|}{ Water year 1992} \\
\hline October & 50.4 & 3.67 & 4.01 & October & 52.3 & 2.62 & 3.10 \\
\hline November & 63.0 & 3.91 & 4.70 & November & 93.8 & 4.69 & 6.46 \\
\hline December & 83.5 & 4.76 & 6.01 & December & 74.6 & 3.62 & 4.44 \\
\hline January & 318 & 34.9 & 38.1 & January & 187 & 12.5 & 14.9 \\
\hline February & 168 & 9.70 & 12.0 & February & 254 & 25.1 & 27.9 \\
\hline March & 187 & 13.8 & 16.5 & March & 102 & 4.73 & 5.92 \\
\hline April & 140 & 8.45 & 10.4 & April & 55.9 & 3.08 & 3.57 \\
\hline May & 667 & 144 & 148 & May & 49.3 & 2.89 & 3.30 \\
\hline June & 191 & 13.0 & 14.7 & June & 55.8 & 3.06 & 3.59 \\
\hline July & 205 & 14.9 & 16.9 & July & 49.4 & 2.83 & 3.28 \\
\hline August & 96.4 & 6.10 & 6.89 & August & 92.7 & 5.76 & 7.21 \\
\hline September & 85.5 & 4.83 & 5.70 & September & 52.4 & 2.81 & 3.37 \\
\hline \multicolumn{4}{|c|}{ Water year 1993} & \multicolumn{4}{|c|}{ Water year 1994} \\
\hline October & 37.7 & 2.61 & 2.88 & October & 73.3 & 5.28 & 6.59 \\
\hline November & 215 & 20.3 & 22.7 & November & 80.5 & 5.39 & 6.42 \\
\hline December & 181 & 16.0 & 18.3 & December & 85.4 & 5.62 & 6.54 \\
\hline January & 174 & 16.3 & 18.7 & January & 91.1 & 5.82 & 6.92 \\
\hline February & 127 & 6.97 & 8.39 & February & 68.5 & 4.06 & 4.80 \\
\hline March & 173 & 11.0 & 12.8 & March & 94.1 & 5.40 & 6.62 \\
\hline April & 118 & 6.18 & 7.61 & April & 86.2 & 4.64 & 5.86 \\
\hline May & 242 & 49.0 & 52.8 & May & 47.4 & 2.79 & 3.29 \\
\hline June & 143 & 10.0 & 11.8 & June & 58.5 & 3.24 & 3.94 \\
\hline July & 99.5 & 6.33 & 7.24 & July & 178 & 15.2 & 17.0 \\
\hline August & 105 & 7.15 & 8.14 & August & 51.3 & 3.21 & 3.70 \\
\hline September & 76.4 & 4.92 & 5.68 & September & 38.8 & 2.91 & 3.17 \\
\hline \multicolumn{4}{|c|}{ Water year 1995} & \multicolumn{4}{|c|}{ Water year 1996} \\
\hline October & 60.5 & 4.15 & 4.77 & October & 126 & 14.9 & 17.1 \\
\hline November & 43.5 & 3.20 & 3.52 & November & 130 & 11.8 & 13.5 \\
\hline December & 80.0 & 6.50 & 7.91 & December & 214 & 45.3 & 48.4 \\
\hline January & 86.2 & 5.95 & 7.02 & January & 164 & 15.2 & 16.9 \\
\hline February & 93.1 & 6.17 & 7.57 & February & 161 & 14.2 & 16.0 \\
\hline March & 123 & 8.93 & 10.7 & March & 190 & 17.7 & 19.6 \\
\hline April & 154 & 13.3 & 15.4 & April & 191 & 14.7 & 19.6 \\
\hline May & 197 & 22.7 & 25.1 & May & 75.2 & 5.03 & 5.63 \\
\hline June & 80.4 & 4.64 & 5.89 & June & 91.7 & 6.56 & 7.48 \\
\hline July & 94.4 & 6.41 & 7.79 & July & 119 & 9.79 & 10.8 \\
\hline August & 122 & 10.6 & 12.5 & August & 92.2 & 8.15 & 8.85 \\
\hline September & 47.2 & 3.50 & 3.90 & September & 63.6 & 6.02 & 6.39 \\
\hline \multicolumn{4}{|c|}{ Water year 1997} & \multicolumn{4}{|c|}{ Water year 1998} \\
\hline October & 49.1 & 4.99 & 5.23 & October & 110 & 15.6 & 16.4 \\
\hline November & 56.1 & 5.87 & 6.17 & November & 170 & 26.3 & 27.8 \\
\hline December & 69.6 & 7.25 & 7.76 & December & 138 & 20.4 & 21.1 \\
\hline January & 109 & 11.1 & 11.8 & January & 257 & 40.6 & 41.9 \\
\hline February & 122 & 12.1 & 13.1 & February & 155 & 23.1 & 23.8 \\
\hline March & 95.6 & 9.39 & 10.2 & March & 192 & 30.0 & 31.3 \\
\hline April & 83.7 & 8.31 & 9.00 & April & 115 & 17.9 & 18.4 \\
\hline May & 80.2 & 8.31 & 9.00 & May & 71.8 & 11.9 & 12.1 \\
\hline June & 182 & 20.7 & 22.0 & June & 65.4 & 11.3 & 11.6 \\
\hline July & 206 & 25.4 & 26.7 & July & 107 & 19.4 & 19.8 \\
\hline August & 103 & 13.3 & 13.8 & August & 86.4 & 16.3 & 16.7 \\
\hline September & 58.6 & 8.03 & 8.26 & September & 722 & 364 & 372 \\
\hline
\end{tabular}


Appendix 2. Monthly mean load tables for selected surface-water sites in the J.B. Converse Lake watershed, Mobile County, Alabama, 1990-98-Continued

$[\mathrm{kg} / \mathrm{d}$, kilograms per day]

Big Creek at County Road 63 near Wilmer, 02479945 (site BIG)

Total Kjeldahl nitrogen

\begin{tabular}{|c|c|c|c|c|c|c|c|}
\hline Month & $\begin{array}{c}\text { Daily mean } \\
\text { constituent } \\
\text { discharge } \\
\text { (kg/d) }\end{array}$ & $\begin{array}{l}\text { Standard } \\
\text { error } \\
(\mathbf{k g} / \mathrm{d})\end{array}$ & $\begin{array}{c}\text { Standard } \\
\text { error of } \\
\text { prediction } \\
(\mathbf{k g} / \mathbf{d})\end{array}$ & Month & $\begin{array}{c}\text { Daily mean } \\
\text { constituent } \\
\text { discharge } \\
(\mathrm{kg} / \mathrm{d})\end{array}$ & $\begin{array}{c}\text { Standard } \\
\text { error } \\
\text { (kg/d) }\end{array}$ & $\begin{array}{c}\text { Standard } \\
\text { error of } \\
\text { prediction } \\
(\mathrm{kg} / \mathrm{d})\end{array}$ \\
\hline \multicolumn{4}{|c|}{ Water year 1991} & \multicolumn{4}{|c|}{ Water year 1992} \\
\hline October & 14.7 & 1.50 & 1.68 & October & 17.3 & 1.21 & 1.46 \\
\hline November & 23.0 & 2.00 & 2.82 & November & 48.8 & 4.18 & 6.31 \\
\hline December & 36.3 & 3.07 & 4.51 & December & 29.9 & 2.13 & 2.75 \\
\hline January & 252 & 50.4 & 55.1 & January & 127 & 14.8 & 17.8 \\
\hline February & 103 & 9.57 & 12.4 & February & 208 & 36.6 & 40.9 \\
\hline March & 134 & 18.8 & 23.0 & March & 54.6 & 3.53 & 4.75 \\
\hline April & 96.4 & 9.10 & 12.1 & April & 23.2 & 1.87 & 2.19 \\
\hline May & 857 & 332 & 344 & May & 20.2 & 1.73 & 2.00 \\
\hline June & 143 & 13.9 & 16.3 & June & 25.0 & 1.96 & 2.38 \\
\hline July & 164 & 17.9 & 21.2 & July & 20.5 & 1.61 & 1.97 \\
\hline August & 49.0 & 4.52 & 5.21 & August & 60.7 & 6.01 & 8.24 \\
\hline September & 40.2 & 3.42 & 4.19 & September & 20.6 & 1.46 & 1.95 \\
\hline \multicolumn{4}{|c|}{ Water year 1993} & \multicolumn{4}{|c|}{ Water year 1994} \\
\hline October & 11.2 & 0.994 & 1.14 & October & 39.3 & 4.72 & 6.78 \\
\hline November & 166 & 26.2 & 29.7 & November & 38.9 & 3.87 & 5.21 \\
\hline December & 129 & 21.0 & 24.8 & December & 40.5 & 3.86 & 4.86 \\
\hline January & 127 & 23.2 & 27.1 & January & 46.9 & 4.48 & 5.80 \\
\hline February & 73.1 & 5.77 & 7.25 & February & 29.8 & 2.46 & 3.11 \\
\hline March & 124 & 12.4 & 14.7 & March & 53.8 & 4.71 & 6.19 \\
\hline April & 76.3 & 5.86 & 7.72 & April & 51.1 & 4.18 & 5.69 \\
\hline May & 302 & 119 & 129 & May & 20.5 & 1.66 & 2.15 \\
\hline June & 116 & 12.8 & 15.7 & June & 28.7 & 2.27 & 3.09 \\
\hline July & 60.5 & 5.56 & 6.63 & July & 151 & 20.6 & 23.6 \\
\hline August & 64.1 & 6.39 & 7.64 & August & 21.4 & 1.74 & 2.25 \\
\hline September & 37.3 & 3.42 & 4.27 & September & 12.1 & 1.11 & 1.27 \\
\hline \multicolumn{4}{|c|}{ Water year 1995} & \multicolumn{4}{|c|}{ Water year 1996} \\
\hline October & 25.0 & 2.30 & 2.94 & October & 88.7 & 19.1 & 22.8 \\
\hline November & 13.2 & 1.17 & 1.37 & November & 72.4 & 10.4 & 12.9 \\
\hline December & 41.8 & 5.85 & 7.94 & December & 174 & 68.9 & 74.0 \\
\hline January & 42.2 & 4.26 & 5.50 & January & 93.4 & 13.9 & 16.0 \\
\hline February & 49.0 & 5.15 & 6.95 & February & 93.6 & 13.6 & 15.9 \\
\hline March & 78.1 & 10.2 & 12.6 & March & 127 & 19.8 & 22.3 \\
\hline April & 117 & 18.9 & 22.2 & April & 125 & 15.4 & 17.9 \\
\hline May & 178 & 37.7 & 41.9 & May & 32.1 & 2.46 & 3.03 \\
\hline June & 45.9 & 4.14 & 5.96 & June & 45.9 & 3.97 & 5.18 \\
\hline July & 57.2 & 6.11 & 8.28 & July & 65.0 & 6.67 & 8.03 \\
\hline August & 86.3 & 13.2 & 16.6 & August & 41.5 & 4.10 & 4.97 \\
\hline September & 15.1 & 1.23 & 1.48 & September & 20.7 & 1.89 & 2.19 \\
\hline \multicolumn{4}{|c|}{ Water year 1997} & \multicolumn{4}{|c|}{ Water year 1998} \\
\hline October & 12.9 & 1.18 & 1.34 & October & 42.5 & 6.12 & 7.09 \\
\hline November & 15.4 & 1.46 & 1.69 & November & 76.7 & 14.9 & 16.9 \\
\hline December & 22.5 & 2.21 & 2.81 & December & 48.9 & 6.98 & 7.85 \\
\hline January & 42.8 & 4.43 & 5.35 & January & 117 & 22.3 & 23.9 \\
\hline February & 52.1 & 5.45 & 6.63 & February & 56.7 & 8.12 & 8.86 \\
\hline March & 39.5 & 4.17 & 5.36 & March & 87.4 & 16.9 & 18.7 \\
\hline April & 34.6 & 3.49 & 4.41 & April & 40.2 & 6.02 & 6.44 \\
\hline May & 34.2 & 3.70 & 4.73 & May & 20.7 & 3.34 & 3.55 \\
\hline June & 105 & 14.2 & 16.1 & June & 17.9 & 3.02 & 3.20 \\
\hline July & 119 & 17.5 & 19.5 & July & 37.1 & 4.67 & 7.03 \\
\hline August & 40.1 & 5.07 & 5.69 & August & 25.7 & 4.67 & 5.04 \\
\hline September & 15.4 & 1.88 & 2.06 & September & 612 & 492 & 504 \\
\hline
\end{tabular}


Appendix 2. Monthly mean load tables for selected surface-water sites in the J.B. Converse Lake watershed, Mobile County, Alabama, 1990-98-Continued

[kg/d, kilograms per day]

Big Creek at County Road 63 near Wilmer, 02479945 (site BIG) Total inorganic nitrogen

\begin{tabular}{|c|c|c|c|c|c|c|c|}
\hline Month & $\begin{array}{c}\text { Daily mean } \\
\text { constituent } \\
\text { discharge } \\
\text { (kg/d) }\end{array}$ & $\begin{array}{c}\text { Standard } \\
\text { error } \\
(\mathbf{k g} / \mathrm{d})\end{array}$ & $\begin{array}{l}\text { Standard } \\
\text { error of } \\
\text { prediction } \\
(\mathbf{k g} / \mathbf{d})\end{array}$ & Month & $\begin{array}{c}\text { Daily mean } \\
\text { constituent } \\
\text { discharge } \\
\text { (kg/d) }\end{array}$ & $\begin{array}{c}\text { Standard } \\
\text { error } \\
(\mathbf{k g} / \mathrm{d})\end{array}$ & $\begin{array}{c}\text { Standard } \\
\text { error of } \\
\text { prediction } \\
(\mathrm{kg} / \mathrm{d})\end{array}$ \\
\hline \multicolumn{4}{|c|}{ Water year 1991} & \multicolumn{4}{|c|}{ Water year 1992} \\
\hline October & 51.4 & 13.3 & 14.9 & October & 41.7 & 7.32 & 9.17 \\
\hline November & 57.2 & 13.4 & 15.6 & November & 52.2 & 8.85 & 11.6 \\
\hline December & 66.0 & 14.3 & 17.0 & December & 52.4 & 9.39 & 11.7 \\
\hline January & 115 & 32.0 & 36.1 & January & 77.5 & 15.3 & 18.8 \\
\hline February & 92.7 & 18.6 & 23.0 & February & 86.6 & 21.3 & 24.8 \\
\hline March & 90.3 & 18.7 & 22.7 & March & 60.0 & 10.1 & 13.0 \\
\hline April & 74.3 & 15.3 & 18.6 & April & 44.1 & 8.96 & 10.8 \\
\hline May & 118 & 45.8 & 48.5 & May & 38.4 & 8.24 & 9.68 \\
\hline June & 71.5 & 16.8 & 19.5 & June & 36.6 & 7.17 & 8.72 \\
\hline July & 66.9 & 16.3 & 18.8 & July & 32.7 & 6.61 & 7.91 \\
\hline August & 48.1 & 11.0 & 12.8 & August & 37.8 & 6.92 & 8.71 \\
\hline September & 46.3 & 9.29 & 11.2 & September & 32.6 & 5.81 & 7.31 \\
\hline \multicolumn{4}{|c|}{ Water year 1993} & \multicolumn{4}{|c|}{ Water year 1994} \\
\hline October & 31.1 & 7.01 & 8.13 & October & 31.6 & 6.52 & 7.89 \\
\hline November & 58.9 & 15.4 & 17.7 & November & 35.5 & 7.71 & 9.16 \\
\hline December & 58.9 & 13.7 & 16.0 & December & 39.3 & 8.60 & 10.1 \\
\hline January & 60.3 & 13.3 & 15.8 & January & 42.2 & 8.96 & 10.7 \\
\hline February & 57.8 & 11.0 & 13.7 & February & 38.8 & 8.03 & 9.73 \\
\hline March & 63.0 & 12.7 & 15.4 & March & 42.0 & 8.27 & 10.1 \\
\hline April & 49.6 & 8.86 & 11.2 & April & 37.7 & 7.27 & 9.00 \\
\hline May & 47.7 & 11.9 & 13.8 & May & 28.1 & 6.38 & 7.42 \\
\hline June & 42.8 & 8.86 & 10.8 & June & 27.7 & 5.53 & 6.70 \\
\hline July & 35.4 & 7.66 & 9.02 & July & 38.4 & 9.79 & 11.2 \\
\hline August & 34.7 & 7.94 & 9.23 & August & 24.4 & 4.96 & 5.94 \\
\hline September & 31.4 & 6.70 & 7.95 & September & 22.9 & 5.25 & 6.10 \\
\hline \multicolumn{4}{|c|}{ Water year 1995} & \multicolumn{4}{|c|}{ Water year 1996} \\
\hline October & 27.2 & 5.66 & 6.74 & October & 29.9 & 7.19 & 8.43 \\
\hline November & 26.6 & 5.90 & 6.91 & November & 35.3 & 8.43 & 9.81 \\
\hline December & 33.1 & 7.36 & 8.72 & December & 38.8 & 10.8 & 12.2 \\
\hline January & 37.2 & 8.06 & 9.59 & January & 45.6 & 10.9 & 12.6 \\
\hline February & 38.9 & 8.05 & 9.87 & February & 46.3 & 10.5 & 12.5 \\
\hline March & 41.8 & 8.69 & 10.5 & March & 48.0 & 11.8 & 13.6 \\
\hline April & 42.1 & 9.44 & 11.3 & April & 47.1 & 10.6 & 12.4 \\
\hline May & 41.1 & 10.8 & 12.4 & May & 29.8 & 5.76 & 7.00 \\
\hline June & 28.5 & 5.49 & 6.81 & June & 29.1 & 5.89 & 7.14 \\
\hline July & 27.9 & 5.69 & 6.89 & July & 30.0 & 6.77 & 7.93 \\
\hline August & 29.1 & 6.57 & 7.79 & August & 26.9 & 6.12 & 7.11 \\
\hline September & 22.8 & 4.57 & 5.51 & September & 24.4 & 5.21 & 6.17 \\
\hline \multicolumn{4}{|c|}{ Water year 1997} & \multicolumn{4}{|c|}{ Water year 1998} \\
\hline October & 23.9 & 5.06 & 5.97 & October & 30.5 & 8.86 & 9.86 \\
\hline November & 26.8 & 5.75 & 6.80 & November & 38.5 & 12.0 & 13.3 \\
\hline December & 30.9 & 6.69 & 7.91 & December & 40.8 & 12.2 & 13.4 \\
\hline January & 39.1 & 8.53 & 10.1 & January & 56.5 & 19.9 & 21.4 \\
\hline February & 41.9 & 9.17 & 11.0 & February & 47.8 & 14.8 & 16.3 \\
\hline March & 36.6 & 8.10 & 9.55 & March & 48.6 & 16.6 & 17.9 \\
\hline April & 32.5 & 7.72 & 8.97 & April & 38.4 & 13.2 & 14.2 \\
\hline May & 29.1 & 7.43 & 8.45 & May & 29.0 & 10.9 & 11.6 \\
\hline June & 37.7 & 10.7 & 11.9 & June & 25.9 & 10.3 & 10.9 \\
\hline July & 37.3 & 11.5 & 12.6 & July & 29.0 & 11.7 & 12.4 \\
\hline August & 28.1 & 8.20 & 9.03 & August & 26.2 & 10.8 & 11.4 \\
\hline September & 23.8 & 6.64 & 7.37 & September & 30.0 & 13.9 & 14.6 \\
\hline
\end{tabular}


Appendix 2. Monthly mean load tables for selected surface-water sites in the J.B. Converse Lake watershed, Mobile County, Alabama, 1990-98-Continued

[kg/d, kilograms per day]

Big Creek at County Road 63 near Wilmer, 02479945 (site BIG)

Total phosphorus

\begin{tabular}{|c|c|c|c|c|c|c|c|}
\hline Month & $\begin{array}{l}\text { Daily mean } \\
\text { constituent } \\
\text { discharge } \\
(\mathrm{kg} / \mathrm{d})\end{array}$ & $\begin{array}{c}\text { Standard } \\
\text { error } \\
\text { (kg/d) }\end{array}$ & $\begin{array}{l}\text { Standard } \\
\text { error of } \\
\text { prediction } \\
(\mathbf{k g} / \mathrm{d})\end{array}$ & Month & $\begin{array}{c}\text { Daily mean } \\
\text { constituent } \\
\text { discharge } \\
\text { (kg/d) }\end{array}$ & $\begin{array}{c}\text { Standard } \\
\text { error } \\
\text { (kg/d) }\end{array}$ & $\begin{array}{l}\text { Standard } \\
\text { error of } \\
\text { prediction } \\
(\mathrm{kg} / \mathrm{d})\end{array}$ \\
\hline \multicolumn{4}{|c|}{ Water year 1991} & \multicolumn{4}{|c|}{ Water year 1992} \\
\hline October & 0.975 & 0.260 & 0.314 & October & 1.24 & .290 & .358 \\
\hline November & 1.54 & .384 & .563 & November & 3.12 & .825 & 1.23 \\
\hline December & 2.38 & .603 & .889 & December & 2.39 & .537 & .714 \\
\hline January & 10.9 & 3.88 & 4.79 & January & 7.22 & 2.03 & 2.68 \\
\hline February & 5.23 & 1.37 & 1.86 & February & 9.41 & 2.86 & 3.78 \\
\hline March & 5.50 & 1.53 & 2.17 & March & 3.11 & .689 & .925 \\
\hline April & 3.56 & .937 & 1.30 & April & 1.27 & .349 & .415 \\
\hline May & 17.0 & 7.91 & 9.24 & May & .983 & .276 & .325 \\
\hline June & 4.72 & 1.45 & 1.72 & June & 1.15 & .291 & .365 \\
\hline July & 5.23 & 1.81 & 2.15 & July & .997 & .245 & .313 \\
\hline August & 2.29 & .060 & .732 & August & 2.55 & .762 & 1.06 \\
\hline September & 2.19 & .550 & .709 & September & 1.32 & .290 & .404 \\
\hline \multicolumn{4}{|c|}{ Water year 1993} & \multicolumn{4}{|c|}{ Water year 1994} \\
\hline October & 0.896 & 0.212 & 0.265 & October & 2.67 & .741 & 1.20 \\
\hline November & 9.05 & 3.44 & 4.17 & November & 3.20 & .782 & 1.15 \\
\hline December & 7.79 & 2.50 & 3.31 & December & 3.62 & .828 & 1.17 \\
\hline January & 7.36 & 2.13 & 3.03 & January & 3.85 & .847 & 1.26 \\
\hline February & 4.99 & 1.06 & 1.47 & February & 2.56 & .552 & .782 \\
\hline March & 6.49 & 1.52 & 2.04 & March & 3.53 & .739 & 1.13 \\
\hline April & 3.82 & .825 & 1.16 & April & 2.86 & .615 & .930 \\
\hline May & 7.32 & 3.09 & 4.40 & May & 1.20 & .290 & .396 \\
\hline June & 4.35 & 1.31 & 1.71 & June & 1.54 & .358 & .509 \\
\hline July & 2.87 & .740 & .937 & July & 6.03 & 2.24 & 2.69 \\
\hline August & 3.27 & .911 & 1.14 & August & 1.38 & .324 & .439 \\
\hline September & 2.43 & .590 & .791 & September & 1.00 & .238 & .298 \\
\hline \multicolumn{4}{|c|}{ Water year 1995} & \multicolumn{4}{|c|}{ Water year 1996} \\
\hline October & 2.15 & 0.524 & 0.727 & October & 5.22 & 2.29 & 3.07 \\
\hline November & 1.48 & .349 & .449 & November & 6.10 & 2.19 & 2.79 \\
\hline December & 3.51 & .981 & 1.58 & December & 10.3 & 4.95 & 6.69 \\
\hline January & 3.84 & .920 & 1.35 & January & 8.22 & 2.67 & 3.39 \\
\hline February & 3.97 & .925 & 1.45 & February & 7.57 & 2.26 & 3.01 \\
\hline March & 5.03 & 1.25 & 1.87 & March & 8.15 & 2.51 & 3.20 \\
\hline April & 5.83 & 1.68 & 2.37 & April & 7.59 & 2.29 & 2.85 \\
\hline May & 7.08 & 2.55 & 3.33 & May & 2.33 & .615 & .758 \\
\hline June & 2.45 & .642 & .939 & June & 2.90 & .845 & 1.08 \\
\hline July & 3.03 & .948 & 1.28 & July & 4.02 & 1.39 & 1.66 \\
\hline August & 4.23 & 1.61 & 2.11 & August & 3.12 & 1.01 & 1.21 \\
\hline September & 1.40 & .355 & .443 & September & 2.12 & .620 & .740 \\
\hline \multicolumn{4}{|c|}{ Water year 1997} & \multicolumn{4}{|c|}{ Water year 1998} \\
\hline October & 1.63 & 0.469 & 0.546 & October & 4.66 & 1.92 & 2.30 \\
\hline November & 2.16 & .630 & .753 & November & 8.08 & 3.65 & 4.39 \\
\hline December & 3.02 & .897 & 1.15 & December & 6.65 & 2.50 & 2.90 \\
\hline January & 5.13 & 1.57 & 1.94 & January & 12.9 & 5.38 & 6.11 \\
\hline February & 5.48 & 1.64 & 2.06 & February & 6.99 & 2.41 & 2.81 \\
\hline March & 3.77 & 1.08 & 1.44 & March & 8.03 & 2.96 & 3.61 \\
\hline April & 2.87 & .834 & 1.10 & April & 4.06 & 1.34 & 1.56 \\
\hline May & 2.51 & .769 & 1.01 & May & 2.05 & .694 & .801 \\
\hline June & 6.35 & 2.50 & 2.89 & June & 1.72 & .601 & .693 \\
\hline July & 7.33 & 3.19 & 3.59 & July & 3.32 & 1.30 & 1.49 \\
\hline August & 3.49 & 1.26 & 1.45 & August & 2.66 & 1.04 & 1.21 \\
\hline September & 1.82 & .594 & .683 & September & 22.5 & 19.6 & 23.3 \\
\hline
\end{tabular}


Appendix 2. Monthly mean load tables for selected surface-water sites in the J.B. Converse Lake watershed, Mobile County, Alabama, 1990-98-Continued

[kg/d, kilograms per day]

Juniper Creek at Glenwood Road near Fairview, 02479948 (site JUN)

Total nitrogen

\begin{tabular}{|c|c|c|c|c|c|c|c|}
\hline Month & $\begin{array}{c}\text { Daily mean } \\
\text { constituent } \\
\text { discharge } \\
(\mathbf{k g} / \mathrm{d})\end{array}$ & $\begin{array}{c}\text { Standard } \\
\text { error } \\
(\mathbf{k g} / \mathrm{d})\end{array}$ & $\begin{array}{l}\text { Standard } \\
\text { error of } \\
\text { prediction } \\
(\mathrm{kg} / \mathrm{d})\end{array}$ & Month & $\begin{array}{c}\text { Daily mean } \\
\text { constituent } \\
\text { discharge } \\
(\mathbf{k g} / \mathbf{d})\end{array}$ & $\begin{array}{c}\text { Standard } \\
\text { error } \\
\text { (kg/d) }\end{array}$ & $\begin{array}{c}\text { Standard } \\
\text { error of } \\
\text { prediction } \\
(\mathrm{kg} / \mathrm{d})\end{array}$ \\
\hline \multicolumn{4}{|c|}{ Water year 1991} & \multicolumn{4}{|c|}{ Water year 1992} \\
\hline October & 19.1 & 3.20 & 3.28 & October & 22.4 & 2.00 & 2.18 \\
\hline November & 20.6 & 2.66 & 2.81 & November & 25.8 & 2.62 & 2.87 \\
\hline December & 22.8 & 2.28 & 2.49 & December & 23.4 & 2.36 & 2.54 \\
\hline January & 47.0 & 6.14 & 6.50 & January & 36.4 & 4.10 & 4.39 \\
\hline February & 32.0 & 2.22 & 2.65 & February & 49.9 & 7.10 & 7.45 \\
\hline March & 39.4 & 3.01 & 3.46 & March & 38.1 & 3.48 & 3.80 \\
\hline April & 36.7 & 2.72 & 3.16 & April & 27.3 & 2.42 & 2.64 \\
\hline May & 72.8 & 11.3 & 11.7 & May & 21.3 & 2.18 & 2.33 \\
\hline June & 49.2 & 4.17 & 4.62 & June & 24.7 & 2.36 & 2.59 \\
\hline July & 43.0 & 3.91 & 4.27 & July & 24.8 & 2.76 & 2.94 \\
\hline August & 28.4 & 2.56 & 2.80 & August & 21.3 & 2.58 & 2.73 \\
\hline September & 26.8 & 2.38 & 2.62 & September & 18.6 & 2.52 & 2.62 \\
\hline
\end{tabular}

Juniper Creek at Glenwood Road near Fairview, 02479948 (site JUN)

Total Kjeldahl nitrogen

\begin{tabular}{|c|c|c|c|c|c|c|c|}
\hline Month & $\begin{array}{c}\text { Daily mean } \\
\text { constituent } \\
\text { discharge } \\
(\mathrm{kg} / \mathrm{d})\end{array}$ & $\begin{array}{c}\text { Standard } \\
\text { error } \\
\text { (kg/d) }\end{array}$ & $\begin{array}{l}\text { Standard } \\
\text { error of } \\
\text { prediction } \\
\text { (kg/d) }\end{array}$ & Month & $\begin{array}{c}\text { Daily mean } \\
\text { constituent } \\
\text { discharge } \\
(\mathrm{kg} / \mathrm{d})\end{array}$ & $\begin{array}{c}\text { Standard } \\
\text { error } \\
\text { (kg/d) }\end{array}$ & $\begin{array}{c}\text { Standard } \\
\text { error of } \\
\text { prediction } \\
\text { (kg/d) }\end{array}$ \\
\hline \multicolumn{4}{|c|}{ Water year 1991} & \multicolumn{4}{|c|}{ Water year 1992} \\
\hline October & 6.54 & 1.62 & 1.74 & October & 6.61 & 1.40 & 1.53 \\
\hline November & 7.45 & 1.57 & 1.86 & November & 8.87 & 2.08 & 2.43 \\
\hline December & 8.47 & 1.58 & 1.91 & December & 6.84 & 1.41 & 1.57 \\
\hline January & 22.4 & 6.82 & 7.38 & January & 14.6 & 3.23 & 3.69 \\
\hline February & 14.2 & 2.38 & 3.00 & February & 21.9 & 5.89 & 6.48 \\
\hline March & 19.2 & 4.20 & 4.78 & March & 15.3 & 2.67 & 3.10 \\
\hline April & 18.5 & 3.57 & 4.26 & April & 9.23 & 1.71 & 1.93 \\
\hline May & 44.4 & 14.6 & 15.3 & May & 6.52 & 1.36 & 1.50 \\
\hline June & 27.0 & 5.85 & 6.46 & June & 8.62 & 1.84 & 2.13 \\
\hline July & 21.6 & 4.90 & 5.40 & July & 8.11 & 2.08 & 2.25 \\
\hline August & 10.7 & 2.31 & 2.54 & August & 6.28 & 1.73 & 1.86 \\
\hline September & 9.50 & 2.02 & 2.27 & September & 4.72 & 1.46 & 1.54 \\
\hline
\end{tabular}


Appendix 2. Monthly mean load tables for selected surface-water sites in the J.B. Converse Lake watershed, Mobile County, Alabama, 1990-98-Continued

$[\mathrm{kg} / \mathrm{d}$, kilograms per day]

Juniper Creek at Glenwood Road near Fairview, 02479948 (site JUN)

Total inorganic nitrogen

\begin{tabular}{|c|c|c|c|c|c|c|c|}
\hline Month & $\begin{array}{c}\text { Daily mean } \\
\text { constituent } \\
\text { discharge } \\
(\mathrm{kg} / \mathrm{d}) \\
\end{array}$ & $\begin{array}{c}\text { Standard } \\
\text { error } \\
\text { (kg/d) }\end{array}$ & $\begin{array}{c}\text { Standard } \\
\text { error of } \\
\text { prediction } \\
(\mathbf{k g} / \mathbf{d})\end{array}$ & Month & $\begin{array}{c}\text { Daily mean } \\
\text { constituent } \\
\text { discharge } \\
(\mathrm{kg} / \mathrm{d})\end{array}$ & $\begin{array}{c}\text { Standard } \\
\text { error } \\
(\mathbf{k g} / \mathbf{d})\end{array}$ & $\begin{array}{c}\text { Standard } \\
\text { error of } \\
\text { prediction } \\
(\mathrm{kg} / \mathrm{d})\end{array}$ \\
\hline \multicolumn{4}{|c|}{ Water year 1991} & \multicolumn{4}{|c|}{ Water year 1992} \\
\hline October & 9.70 & 0.665 & 0.711 & October & 16.0 & 0.912 & 1.00 \\
\hline November & 10.9 & .626 & .689 & November & 17.0 & 1.01 & 1.11 \\
\hline December & 12.5 & .657 & .733 & December & 17.1 & .983 & 1.08 \\
\hline January & 18.5 & 1.39 & 1.48 & January & 20.4 & 1.13 & 1.25 \\
\hline February & 16.8 & .817 & .939 & February & 23.5 & 1.62 & 1.74 \\
\hline March & 19.2 & .970 & 1.09 & March & 20.5 & 1.02 & 1.15 \\
\hline April & 19.1 & 1.03 & 1.15 & April & 17.1 & .896 & 1.00 \\
\hline May & 26.5 & 2.75 & 2.83 & May & 14.4 & .863 & .940 \\
\hline June & 21.7 & 1.34 & 1.45 & June & 13.9 & .784 & .866 \\
\hline July & 20.2 & 1.30 & 1.40 & July & 12.8 & .830 & .894 \\
\hline August & 17.1 & 1.04 & 1.13 & August & 11.2 & .777 & .830 \\
\hline September & 16.8 & .971 & 1.07 & September & 9.98 & .802 & .843 \\
\hline
\end{tabular}

Juniper Creek at Glenwood Road near Fairview, 02479948 (site JUN)

Total phosphorus

\begin{tabular}{|c|c|c|c|c|c|c|c|}
\hline Month & $\begin{array}{c}\text { Daily mean } \\
\text { constituent } \\
\text { discharge } \\
(\mathrm{kg} / \mathrm{d})\end{array}$ & $\begin{array}{c}\text { Standard } \\
\text { error } \\
\text { (kg/d) }\end{array}$ & $\begin{array}{l}\text { Standard } \\
\text { error of } \\
\text { prediction } \\
(\mathbf{k g} / \mathrm{d})\end{array}$ & Month & $\begin{array}{c}\text { Daily mean } \\
\text { constituent } \\
\text { discharge } \\
\text { (kg/d) }\end{array}$ & $\begin{array}{c}\text { Standard } \\
\text { error } \\
\text { (kg/d) }\end{array}$ & $\begin{array}{c}\text { Standard } \\
\text { error of } \\
\text { prediction } \\
(\mathrm{kg} / \mathrm{d})\end{array}$ \\
\hline \multicolumn{4}{|c|}{ Water year 1991} & \multicolumn{4}{|c|}{ Water year 1992} \\
\hline October & 0.220 & 0.134 & 0.155 & October & 1.31 & 0.585 & 0.713 \\
\hline November & .053 & .284 & .489 & November & 3.91 & 2.84 & 3.95 \\
\hline December & .770 & .384 & .622 & December & 2.00 & .970 & 1.24 \\
\hline January & 13.1 & 14.7 & 18.4 & January & 6.56 & 4.65 & 6.12 \\
\hline February & 1.33 & .657 & 1.15 & February & 19.5 & 21.9 & 28.3 \\
\hline March & 3.00 & 2.21 & 3.59 & March & 2.42 & 1.21 & 1.65 \\
\hline April & 1.12 & .600 & .902 & April & .640 & .339 & .398 \\
\hline May & 9.67 & 9.88 & 11.7 & May & .313 & .179 & .209 \\
\hline June & 1.60 & .934 & 1.13 & June & .586 & .304 & .451 \\
\hline July & 1.56 & .932 & 1.13 & July & .628 & .344 & .426 \\
\hline August & .950 & .481 & .615 & August & .670 & .390 & .492 \\
\hline September & 1.40 & .719 & .926 & September & .696 & .438 & .506 \\
\hline
\end{tabular}


Appendix 2. Monthly mean load tables for selected surface-water sites in the J.B. Converse Lake watershed, Mobile County, Alabama, 1990-98-Continued

[kg/d, kilograms per day]

Collins Creek at Glenwood Road near Fairview, 02479950 (site COL)

Total nitrogen

\begin{tabular}{lccc|lccc}
\hline Month & $\begin{array}{c}\text { Daily mean } \\
\text { constituent } \\
\text { discharge } \\
(\mathbf{k g} / \mathbf{d})\end{array}$ & $\begin{array}{c}\text { Standard } \\
\text { error } \\
\mathbf{( k g / d )}\end{array}$ & $\begin{array}{c}\text { Standard } \\
\text { error of } \\
\text { prediction } \\
\mathbf{( k g / d )}\end{array}$ & Month & $\begin{array}{c}\text { Daily mean } \\
\text { constituent } \\
\text { discharge } \\
(\mathbf{k g} / \mathbf{d})\end{array}$ & $\begin{array}{c}\text { Standard } \\
\text { error } \\
\mathbf{( k g / d )}\end{array}$ & $\begin{array}{c}\text { Standard } \\
\text { error of } \\
\text { prediction } \\
(\mathbf{k g} / \mathbf{d})\end{array}$ \\
\hline & Water year $\mathbf{1 9 9 1}$ & & & Water year 1992 & \\
\hline October & 10.0 & 1.25 & 1.30 & October & 12.8 & 1.10 & 1.18 \\
November & 11.1 & 1.16 & 1.22 & November & 15.0 & 1.24 & 1.36 \\
December & 15.1 & 1.67 & 1.76 & December & 12.6 & 1.09 & 1.17 \\
January & 41.1 & 7.13 & 7.48 & January & 18.2 & 1.65 & 1.80 \\
February & 19.5 & 1.39 & 1.62 & February & 35.2 & 5.83 & 6.14 \\
March & 19.0 & 1.23 & 1.47 & March & 17.5 & 1.41 & 1.54 \\
April & 19.1 & 1.20 & 1.41 & April & 12.2 & .91 & 1.00 \\
May & 55.6 & 11.4 & 11.8 & May & 10.0 & 1.09 & 1.14 \\
June & 28.4 & 1.84 & 2.09 & June & 14.2 & 1.20 & 1.31 \\
July & 25.7 & 1.74 & 1.96 & July & 12.6 & 1.24 & 1.32 \\
August & 17.4 & 1.21 & 1.34 & August & 9.95 & 1.00 & 1.06 \\
September & 15.7 & 1.14 & 1.26 & September & 9.51 & 1.18 & 1.22 \\
\hline
\end{tabular}

Collins Creek at Glenwood Road near Fairview, 02479950 (site COL)

Total Kjeldahl nitrogen

\begin{tabular}{|c|c|c|c|c|c|c|c|}
\hline Month & $\begin{array}{c}\text { Daily mean } \\
\text { constituent } \\
\text { discharge } \\
(\mathrm{kg} / \mathrm{d})\end{array}$ & $\begin{array}{c}\text { Standard } \\
\text { error } \\
\text { (kg/d) }\end{array}$ & $\begin{array}{c}\text { Standard } \\
\text { error of } \\
\text { prediction } \\
\text { (kg/d })\end{array}$ & Month & $\begin{array}{c}\text { Daily mean } \\
\text { constituent } \\
\text { discharge } \\
(\mathrm{kg} / \mathrm{d})\end{array}$ & $\begin{array}{c}\text { Standard } \\
\text { error } \\
(\mathbf{k g} / \mathrm{d})\end{array}$ & $\begin{array}{c}\text { Standard } \\
\text { error of } \\
\text { prediction } \\
(\mathrm{kg} / \mathrm{d})\end{array}$ \\
\hline \multicolumn{4}{|c|}{ Water year 1991} & \multicolumn{4}{|c|}{ Water year 1992} \\
\hline October & 5.02 & 0.736 & 0.780 & October & 6.29 & 0.773 & 0.836 \\
\hline November & 5.43 & .663 & .738 & November & 7.57 & .890 & 1.01 \\
\hline December & 7.75 & .930 & 1.03 & December & 5.83 & .687 & .749 \\
\hline January & 34.6 & 13.0 & 13.5 & January & 10.1 & 1.27 & 1.46 \\
\hline February & 11.7 & 1.21 & 1.54 & February & 28.6 & 9.40 & 9.97 \\
\hline March & 12.1 & 1.29 & 1.60 & March & 10.4 & 1.12 & 1.28 \\
\hline April & 12.6 & 1.23 & 1.49 & April & 7.00 & .718 & .804 \\
\hline May & 59.8 & 24.0 & 24.8 & May & 5.95 & .783 & .842 \\
\hline June & 21.2 & 2.35 & 2.63 & June & 9.48 & 1.39 & 1.50 \\
\hline July & 18.6 & 2.11 & 2.35 & July & 8.11 & 1.38 & 1.45 \\
\hline August & 10.5 & 1.14 & 1.26 & August & 5.85 & 1.00 & 1.04 \\
\hline September & 8.77 & .953 & 1.07 & September & 5.23 & 1.09 & 1.12 \\
\hline
\end{tabular}


Appendix 2. Monthly mean load tables for selected surface-water sites in the J.B. Converse Lake watershed, Mobile County, Alabama, 1990-98-Continued

[kg/d, kilograms per day]

Collins Creek at Glenwood Road near Fairview, 02479950 (site COL)

Total inorganic nitrogen

\begin{tabular}{|c|c|c|c|c|c|c|c|}
\hline Month & $\begin{array}{c}\text { Daily mean } \\
\text { constituent } \\
\text { discharge } \\
(\mathrm{kg} / \mathrm{d})\end{array}$ & $\begin{array}{c}\text { Standard } \\
\text { error } \\
(\mathbf{k g} / \mathbf{d})\end{array}$ & $\begin{array}{l}\text { Standard } \\
\text { error of } \\
\text { prediction } \\
(\mathbf{k g} / \mathrm{d})\end{array}$ & Month & $\begin{array}{c}\text { Daily mean } \\
\text { constituent } \\
\text { discharge } \\
\text { (kg/d) }\end{array}$ & $\begin{array}{c}\text { Standard } \\
\text { error } \\
\text { (kg/d) }\end{array}$ & $\begin{array}{c}\text { Standard } \\
\text { error of } \\
\text { prediction } \\
(\mathrm{kg} / \mathrm{d})\end{array}$ \\
\hline \multicolumn{4}{|c|}{ Water year 1991} & \multicolumn{4}{|c|}{ Water year 1992} \\
\hline October & 3.88 & 0.326 & 0.349 & October & 5.23 & 0.392 & 0.425 \\
\hline November & 4.41 & .315 & .348 & November & 6.05 & .426 & .471 \\
\hline December & 6.09 & .424 & .468 & December & 5.52 & .391 & .429 \\
\hline January & 7.97 & .596 & .649 & January & 6.68 & .447 & .498 \\
\hline February & 6.34 & .370 & .428 & February & 7.89 & .635 & .689 \\
\hline March & 5.54 & .335 & .381 & March & 6.24 & .408 & .454 \\
\hline April & 5.41 & .341 & .387 & April & 4.32 & .267 & .302 \\
\hline May & 8.08 & .670 & .718 & May & 3.19 & .244 & .265 \\
\hline June & 7.40 & .516 & .569 & June & 4.66 & .378 & .409 \\
\hline July & 7.21 & .512 & .562 & July & 4.43 & .413 & .438 \\
\hline August & 6.09 & .418 & .460 & August & 3.68 & .331 & .353 \\
\hline September & 5.80 & .394 & .438 & September & 3.93 & .455 & .473 \\
\hline
\end{tabular}

Collins Creek at Glenwood Road near Fairview, 02479950 (site COL)

Total phosphorus

\begin{tabular}{lccc|lcrr}
\hline Month & $\begin{array}{c}\text { Daily mean } \\
\text { constituent } \\
\text { discharge } \\
(\mathbf{k g} / \mathbf{d})\end{array}$ & $\begin{array}{c}\text { Standard } \\
\text { error } \\
\mathbf{( k g / d )}\end{array}$ & $\begin{array}{c}\text { Standard } \\
\text { error of } \\
\text { prediction } \\
\mathbf{( k g / d )}\end{array}$ & \multicolumn{1}{c|}{ Month } & $\begin{array}{c}\text { Daily mean } \\
\text { constituent } \\
\text { discharge } \\
(\mathbf{k g} / \mathbf{d})\end{array}$ & $\begin{array}{c}\text { Standard } \\
\text { error } \\
\mathbf{( k g / d )}\end{array}$ & $\begin{array}{c}\text { Standard } \\
\text { error of } \\
\text { prediction } \\
(\mathbf{k g} / \mathbf{d})\end{array}$ \\
\hline & Water year $\mathbf{1 9 9 1}$ & & & & Water year 1992. & \\
\hline October & 0.248 & 0.092 & 0.099 & October & 0.515 & 0.159 & 0.175 \\
November & .344 & .107 & .121 & November & .789 & .232 & .270 \\
December & .589 & .176 & .200 & December & .712 & .208 & .232 \\
January & 1.37 & .623 & .671 & January & 1.25 & .388 & .452 \\
February & .820 & .206 & .263 & February & 2.04 & .811 & .891 \\
March & .744 & .203 & .256 & March & 1.08 & .306 & .351 \\
April & .636 & .163 & .200 & April & .610 & .156 & .179 \\
May & 1.47 & .540 & .597 & May & .419 & .127 & .141 \\
June & .865 & .253 & .286 & June & .629 & .214 & .236 \\
July & .778 & .234 & .263 & July & .547 & .211 & .226 \\
August & .523 & .150 & .167 & August & .463 & .171 & .184 \\
September & .542 & .153 & .173 & September & .503 & .240 & .251 \\
\hline
\end{tabular}


Appendix 2. Monthly mean load tables for selected surface-water sites in the J.B. Converse Lake watershed, Mobile County, Alabama, 1990-98-Continued

$[\mathrm{kg} / \mathrm{d}$, kilograms per day]

Long Branch near Wilmer, 02479955

(site LON)

Total nitrogen

\begin{tabular}{lccc}
\hline Month & $\begin{array}{c}\text { Oaily mean } \\
\text { constituent } \\
\text { discharge } \\
\text { (kg/d) }\end{array}$ & $\begin{array}{c}\text { Standard } \\
\text { error } \\
\text { (kg/d) }\end{array}$ & $\begin{array}{c}\text { Standard } \\
\text { error of } \\
\text { prediction } \\
\text { (kg/d) }\end{array}$ \\
\hline \multicolumn{4}{c}{ Water year $\mathbf{1 9 9 1}$} \\
\hline October & 1.51 & 0.487 & 0.499 \\
November & 5.35 & 1.01 & 1.06 \\
December & 9.61 & 2.24 & 2.32 \\
January & 34.8 & 37.1 & 37.3 \\
February & 19.6 & 3.35 & 3.61 \\
March & 12.9 & 6.25 & 6.41 \\
April & 13.6 & 2.13 & 2.31 \\
May & 19.9 & 7.82 & 8.16 \\
June & 22.0 & 2.40 & 2.77 \\
July & 19.6 & 3.23 & 3.47 \\
August & 13.2 & 2.25 & 2.40 \\
September & 6.41 & 1.52 & 1.58 \\
\hline
\end{tabular}

Long Branch near Wilmer, 02479955

(site LON)

Total Kjeldahl nitrogen

\begin{tabular}{lccc}
\hline Month & $\begin{array}{c}\text { Daily mean } \\
\text { constituent } \\
\text { discharge } \\
(\mathbf{k g} / \mathbf{d})\end{array}$ & $\begin{array}{c}\text { Standard } \\
\text { error } \\
\mathbf{( k g / d )}\end{array}$ & $\begin{array}{c}\text { Standard } \\
\text { error of } \\
\text { prediction } \\
\mathbf{( k g / d )}\end{array}$ \\
\hline \multicolumn{4}{c}{ Water year $\mathbf{1 9 9 1}$} \\
\hline October & 1.59 & 0.558 & 0.591 \\
November & 1.87 & .520 & .571 \\
December & 2.09 & .608 & .660 \\
January & 11.56 & 6.07 & 6.32 \\
February & 6.18 & 1.61 & 1.84 \\
March & 6.16 & 1.54 & 1.81 \\
April & 6.18 & 1.57 & 1.85 \\
May & 19.78 & 9.36 & 9.75 \\
June & 9.87 & 2.64 & 2.92 \\
July & 10.34 & 2.85 & 3.21 \\
August & 7.34 & 2.20 & 2.39 \\
September & 5.72 & 2.57 & 2.67 \\
\hline
\end{tabular}


Appendix 2. Monthly mean load tables for selected surface-water sites in the J.B. Converse Lake watershed, Mobile County, Alabama, 1990-98-Continued

[kg/d, kilograms per day]

Long Branch near Wilmer, 02479955

(site LON)

Total inorganic nitrogen

\begin{tabular}{lccc}
\hline Month & $\begin{array}{c}\text { Daily mean } \\
\text { constituent } \\
\text { discharge } \\
\mathbf{( k g / d )}\end{array}$ & $\begin{array}{c}\text { Standard } \\
\text { error } \\
\text { (kg/d) }\end{array}$ & $\begin{array}{c}\text { Standard } \\
\text { error of } \\
\text { prediction } \\
\text { (kg/d) }\end{array}$ \\
\hline \multicolumn{4}{c}{ Water year 1991 } \\
\hline October & 2.58 & 0.282 & 0.299 \\
November & 3.68 & .323 & .354 \\
December & 5.15 & .486 & .525 \\
January & 37.0 & 7.08 & 7.37 \\
February & 17.0 & 1.45 & 1.65 \\
March & 15.9 & 1.34 & 1.58 \\
April & 11.6 & .956 & 1.10 \\
May & 30.0 & 4.95 & 5.16 \\
June & 9.84 & .861 & .947 \\
July & 8.53 & .789 & .883 \\
August & 5.37 & .536 & .578 \\
September & 4.75 & .720 & .744 \\
\hline
\end{tabular}

Long Branch near Wilmer, 02479955 (site LON) Total phosphorus

\begin{tabular}{lccc}
\hline Month & $\begin{array}{c}\text { Daily mean } \\
\text { constituent } \\
\text { discharge } \\
(\mathbf{k g} / \mathbf{d})\end{array}$ & $\begin{array}{c}\text { Standard } \\
\text { error } \\
(\mathbf{k g} / \mathbf{d})\end{array}$ & $\begin{array}{c}\text { Standard } \\
\text { error of } \\
\text { prediction } \\
\text { (kg/d) }\end{array}$ \\
\hline \multicolumn{4}{c}{ Water year $\mathbf{1 9 9 1}$} \\
\hline October & 0.058 & 0.051 & 0.052 \\
November & .116 & .168 & .072 \\
December & .148 & .068 & .074 \\
January & .223 & .118 & .127 \\
February & .234 & .093 & .104 \\
March & .214 & .078 & .089 \\
April & .202 & .075 & .086 \\
May & .306 & .172 & .182 \\
June & .308 & .125 & .139 \\
July & .343 & .127 & .143 \\
August & .361 & .158 & .173 \\
September & .313 & .220 & .228 \\
\hline
\end{tabular}


Appendix 2. Monthly mean load tables for selected surface-water sites in the J.B. Converse Lake watershed, Mobile County, Alabama, 1990-98-Continued

[kg/d, kilograms per day]

Boggy Branch near Wilmer, 02479960

(site BOG)

\section{Total nitrogen}

\begin{tabular}{lccc}
\hline Month & $\begin{array}{c}\text { Daily mean } \\
\text { constituent } \\
\text { discharge } \\
\text { (kg/d) }\end{array}$ & $\begin{array}{c}\text { Standard } \\
\text { error } \\
\text { (kg/d) }\end{array}$ & $\begin{array}{c}\text { Standard } \\
\text { error of } \\
\text { prediction } \\
\text { (kg/d) }\end{array}$ \\
\hline Water year $\mathbf{1 9 9 1}$ & \\
\hline October & 2.28 & 0.386 & 0.441 \\
November & 6.24 & 3.65 & 3.93 \\
December & 6.90 & 2.50 & 2.73 \\
January & -128 & 301 & 303 \\
February & 8.42 & 2.33 & 3.15 \\
March & -2.90 & 23.0 & 23.9 \\
April & 25.5 & 11.3 & 11.7 \\
May & -77.2 & 201 & 204 \\
June & 22.0 & 6.17 & 6.61 \\
July & -4.91 & 28.0 & 29.0 \\
August & 6.05 & .798 & .914 \\
September & 2.95 & .915 & .951 \\
\hline
\end{tabular}

Boggy Branch near Wilmer, 02479960

(site BOG)

Total Kjeldahl nitrogen

\begin{tabular}{lccc}
\hline Month & $\begin{array}{c}\text { Daily mean } \\
\text { constituent } \\
\text { discharge } \\
\text { (kg/d) }\end{array}$ & $\begin{array}{c}\text { Standard } \\
\text { error } \\
\mathbf{( k g / d )}\end{array}$ & $\begin{array}{c}\text { Standard } \\
\text { error of } \\
\text { prediction } \\
\text { (kg/d) }\end{array}$ \\
\hline \multicolumn{4}{c}{ Water year $\mathbf{1 9 9 1}$} \\
\hline October & 1.96 & 0.401 & 0.466 \\
November & 3.29 & 1.12 & 1.37 \\
December & 3.30 & .765 & .917 \\
January & 22.6 & 9.54 & 10.1 \\
February & 9.67 & 1.97 & 2.32 \\
March & 13.0 & 2.55 & 3.00 \\
April & 20.3 & 4.02 & 4.64 \\
May & 60.5 & 17.9 & 18.8 \\
June & 16.3 & 2.89 & 3.35 \\
July & 22.4 & 6.40 & 7.15 \\
August & 4.57 & .808 & .896 \\
September & 1.72 & .453 & .487 \\
\hline
\end{tabular}


Appendix 2. Monthly mean load tables for selected surface-water sites in the J.B. Converse Lake watershed, Mobile County, Alabama, 1990-98-Continued

[kg/d, kilograms per day]

Boggy Branch near Wilmer, 02479960

(site BOG)

Total inorganic nitrogen

\begin{tabular}{lccc}
\hline Month & $\begin{array}{c}\text { Daily mean } \\
\text { constituent } \\
\text { discharge } \\
\text { (kg/d) }\end{array}$ & $\begin{array}{c}\text { Standard } \\
\text { error } \\
\text { (kg/d) }\end{array}$ & $\begin{array}{c}\text { Standard } \\
\text { error of } \\
\text { prediction } \\
\text { (kg/d) }\end{array}$ \\
\hline \multicolumn{4}{c}{ Water year $\mathbf{1 9 9 1}$} \\
\hline October & 0.573 & 0.093 & 0.109 \\
November & 1.41 & .361 & .442 \\
December & 1.91 & .341 & .406 \\
January & 12.9 & 4.34 & 4.56 \\
February & 4.51 & .713 & .834 \\
March & 4.76 & .773 & .912 \\
April & 4.54 & .698 & .802 \\
May & 10.8 & 2.54 & 2.68 \\
June & 2.93 & .414 & .477 \\
July & 4.58 & 1.01 & 1.12 \\
August & 1.68 & .244 & .269 \\
September & 1.20 & .259 & .280 \\
\hline
\end{tabular}

Boggy Branch near Wilmer, 02479960

(site BOG)

Total phosphorus

\begin{tabular}{lccc}
\hline \multicolumn{1}{c}{ Month } & $\begin{array}{c}\text { Daily mean } \\
\text { constituent } \\
\text { discharge } \\
\text { (kg/d) }\end{array}$ & $\begin{array}{c}\text { Standard } \\
\text { error } \\
\mathbf{( k g / d )}\end{array}$ & $\begin{array}{c}\text { Standard } \\
\text { error of } \\
\text { prediction } \\
\text { (kg/d) }\end{array}$ \\
\hline \multicolumn{4}{c}{ Water year $\mathbf{1 9 9 1}$} \\
\hline October & 0.124 & 0.023 & 0.025 \\
November & .139 & .021 & .023 \\
December & .165 & .024 & .027 \\
January & .230 & .052 & .054 \\
February & .232 & .034 & .037 \\
March & .243 & .034 & .038 \\
April & .250 & .038 & .042 \\
May & .290 & .068 & .070 \\
June & .239 & .037 & .041 \\
July & .239 & .037 & .040 \\
August & .215 & .036 & .039 \\
September & .196 & .052 & .053 \\
\hline
\end{tabular}


Appendix 2. Monthly mean load tables for selected surface-water sites in the J.B. Converse Lake watershed, Mobile County, Alabama, 1990-98-Continued

[kg/d, kilograms per day]

Crooked Creek near Fairview, 02479980 (site CRO)

Total nitrogen

\begin{tabular}{|c|c|c|c|c|c|c|c|}
\hline Month & $\begin{array}{c}\text { Daily mean } \\
\text { constituent } \\
\text { discharge } \\
\text { (kg/d) }\end{array}$ & $\begin{array}{c}\text { Standard } \\
\text { error } \\
(\mathbf{k g} / \mathbf{d})\end{array}$ & $\begin{array}{c}\text { Standard } \\
\text { error of } \\
\text { prediction } \\
(\mathrm{kg} / \mathrm{d})\end{array}$ & Month & $\begin{array}{c}\text { Daily mean } \\
\text { constituent } \\
\text { discharge } \\
\text { (kg/d) }\end{array}$ & $\begin{array}{c}\text { Standard } \\
\text { error } \\
(\mathbf{k g} / \mathbf{d})\end{array}$ & $\begin{array}{c}\text { Standard } \\
\text { error of } \\
\text { prediction } \\
\text { (kg/d) }\end{array}$ \\
\hline \multicolumn{4}{|c|}{ Water year 1991} & \multicolumn{4}{|c|}{ Water year 1992} \\
\hline October & 15.0 & 1.64 & 1.81 & October & 18.8 & 1.49 & 1.76 \\
\hline November & 19.3 & 1.94 & 2.31 & November & 30.2 & 3.18 & 3.91 \\
\hline December & 26.8 & 3.08 & 3.65 & December & 20.9 & 1.70 & 2.01 \\
\hline January & 80.2 & 27.4 & 28.1 & January & 42.4 & 6.87 & 7.66 \\
\hline February & 38.4 & 4.62 & 5.35 & February & 51.8 & 10.3 & 11.1 \\
\hline March & 40.4 & 5.71 & 6.40 & March & 31.6 & 2.51 & 3.22 \\
\hline April & 46.2 & 6.01 & 6.77 & April & 18.0 & 1.46 & 1.72 \\
\hline May & 90.1 & 20.2 & 21.0 & May & 18.8 & 1.50 & 1.95 \\
\hline June & 40.9 & 4.41 & 4.98 & June & 25.9 & 2.13 & 2.68 \\
\hline July & 45.9 & 5.38 & 6.08 & July & 19.4 & 1.63 & 1.94 \\
\hline August & 30.0 & 2.93 & 3.33 & August & 18.2 & 1.55 & 1.84 \\
\hline September & 23.7 & 2.03 & 2.41 & September & 20.1 & 1.81 & 2.31 \\
\hline \multicolumn{4}{|c|}{ Water year 1993} & \multicolumn{4}{|c|}{ Water year 1994} \\
\hline October & 14.7 & 1.41 & 1.59 & October & 23.9 & 3.33 & 4.05 \\
\hline November & 42.9 & 5.76 & 6.54 & November & 19.4 & 2.15 & 2.39 \\
\hline December & 37.4 & 6.04 & 6.87 & December & 19.2 & 2.15 & 2.38 \\
\hline January & 42.9 & 12.9 & 13.5 & January & 28.1 & 3.96 & 4.65 \\
\hline February & 29.7 & 2.77 & 3.23 & February & 15.6 & 1.68 & 1.87 \\
\hline March & 51.0 & 7.98 & 8.84 & March & 22.7 & 2.06 & 2.49 \\
\hline April & 32.8 & 2.76 & 3.29 & April & 21.6 & 1.82 & 2.26 \\
\hline May & 51.6 & 13.0 & 13.8 & May & 16.2 & 1.51 & 1.75 \\
\hline June & 36.8 & 3.58 & 4.18 & June & 30.4 & 5.29 & 6.25 \\
\hline July & 35.2 & 3.68 & 1.46 & July & 54.1 & 8.89 & 9.91 \\
\hline August & 29.5 & 3.13 & 3.50 & August & 21.6 & 2.18 & 2.50 \\
\hline September & 30.9 & 3.57 & 3.97 & September & 15.4 & 1.75 & 1.92 \\
\hline \multicolumn{4}{|c|}{ Water year 1995} & \multicolumn{4}{|c|}{ Water year 1996} \\
\hline October & 20.7 & 2.39 & 2.73 & October & 49.1 & 12.4 & 13.3 \\
\hline November & 15.6 & 1.91 & 2.14 & November & 38.8 & 6.54 & 7.34 \\
\hline December & 22.7 & 3.40 & 4.04 & December & 49.5 & 23.5 & 24.0 \\
\hline January & 29.4 & 4.07 & 4.71 & January & 42.9 & 7.11 & 7.82 \\
\hline February & 19.5 & 2.06 & 2.36 & February & 38.6 & 5.64 & 6.39 \\
\hline March & 32.4 & 4.12 & 4.87 & March & 42.3 & 6.77 & 7.55 \\
\hline April & 37.6 & 4.91 & 5.78 & April & 50.8 & 7.41 & 8.29 \\
\hline May & 63.8 & 27.4 & 28.1 & May & 24.0 & 1.97 & 2.31 \\
\hline June & 32.5 & 3.05 & 3.85 & June & 25.2 & 2.12 & 2.54 \\
\hline July & 27.5 & 2.87 & 3.06 & July & 35.7 & 3.73 & 4.30 \\
\hline August & 55.3 & 13.3 & 14.3 & August & 42.3 & 5.18 & 5.84 \\
\hline September & 22.1 & 2.46 & 2.72 & September & 28.1 & 3.35 & 3.73 \\
\hline \multicolumn{4}{|c|}{ Water year 1997} & \multicolumn{4}{|c|}{ Water year 1998} \\
\hline October & 20.4 & 2.50 & 2.71 & October & 39.7 & 7.84 & 8.50 \\
\hline November & 17.3 & 2.27 & 2.43 & November & 58.6 & 17.2 & 17.9 \\
\hline December & 29.8 & 4.64 & 5.21 & December & 37.7 & 6.82 & 7.31 \\
\hline January & 33.3 & 4.91 & 5.47 & January & 95.6 & 34.3 & 34.9 \\
\hline February & 35.9 & 4.71 & 5.32 & February & 45.6 & 7.76 & 8.27 \\
\hline March & 32.1 & 4.73 & 5.35 & March & 55.5 & 18.4 & 18.9 \\
\hline April & 25.4 & 2.69 & 3.23 & April & 37.3 & 5.55 & 6.00 \\
\hline May & 42.5 & 10.9 & 11.6 & May & 26.8 & 3.90 & 4.24 \\
\hline June & 75.0 & 18.5 & 19.4 & June & 22.6 & 3.47 & 3.73 \\
\hline July & 137 & 50.1 & 50.9 & July & 47.3 & 9.22 & 9.79 \\
\hline August & 54.4 & 7.79 & 8.32 & August & 30.3 & 5.33 & 5.65 \\
\hline September & 30.4 & 4.18 & 4.46 & September & 80.9 & 43.8 & 44.3 \\
\hline
\end{tabular}


Appendix 2. Monthly mean load tables for selected surface-water sites in the J.B. Converse Lake watershed, Mobile County, Alabama, 1990-98-Continued

$[\mathrm{kg} / \mathrm{d}$, kilograms per day]

Crooked Creek near Fairview, 02479980 (site CRO)

Total Kjeldahl nitrogen

\begin{tabular}{|c|c|c|c|c|c|c|c|}
\hline Month & $\begin{array}{c}\text { Daily mean } \\
\text { constituent } \\
\text { discharge } \\
\text { (kg/d) }\end{array}$ & $\begin{array}{c}\text { Standard } \\
\text { error } \\
(\mathbf{k g} / \mathbf{d})\end{array}$ & $\begin{array}{l}\text { Standard } \\
\text { error of } \\
\text { prediction } \\
\text { (kg/d) }\end{array}$ & Month & $\begin{array}{c}\text { Daily mean } \\
\text { constituent } \\
\text { discharge } \\
(\mathrm{kg} / \mathrm{d})\end{array}$ & $\begin{array}{c}\text { Standard } \\
\text { error } \\
(\mathrm{kg} / \mathrm{d})\end{array}$ & $\begin{array}{c}\text { Standard } \\
\text { error of } \\
\text { prediction } \\
(\mathrm{kg} / \mathrm{d})\end{array}$ \\
\hline \multicolumn{4}{|c|}{ Water year 1991} & \multicolumn{4}{|c|}{ Water year 1992} \\
\hline October & 5.72 & 1.11 & 1.23 & October & 6.58 & .870 & 1.07 \\
\hline November & 7.77 & 1.39 & 1.83 & November & 12.7 & 2.86 & 3.73 \\
\hline December & 12.6 & 2.91 & 3.63 & December & 6.95 & .940 & 1.66 \\
\hline January & 57.5 & 42.7 & 43.8 & January & 22.7 & 9.26 & 10.4 \\
\hline February & 23.3 & 6.29 & 4.52 & February & 33.5 & 16.4 & 17.7 \\
\hline March & 28.3 & 9.24 & 10.5 & March & 17.4 & 2.90 & 3.99 \\
\hline April & 38.0 & 10.2 & 11.7 & April & 8.76 & 1.19 & 1.46 \\
\hline May & 92.9 & 45.5 & 47.5 & May & 10.8 & 1.47 & 2.23 \\
\hline June & 29.1 & 5.41 & 6.43 & June & 15.3 & 2.24 & 3.07 \\
\hline July & 33.2 & 7.14 & 8.50 & July & 9.34 & 1.32 & 1.66 \\
\hline August & 15.3 & 2.51 & 2.97 & August & 7.67 & 1.07 & 1.36 \\
\hline September & 10.0 & 1.45 & 1.82 & September & 7.31 & 1.22 & 1.77 \\
\hline \multicolumn{4}{|c|}{ Water year 1993} & \multicolumn{4}{|c|}{ Water year 1994} \\
\hline October & 4.47 & 0.669 & 0.796 & October & 9.09 & 2.83 & 3.73 \\
\hline November & 17.7 & 4.79 & 5.64 & November & 5.24 & .879 & 1.04 \\
\hline December & 16.1 & 6.91 & 7.95 & December & 5.18 & .883 & 1.04 \\
\hline January & 17.9 & 12.6 & 13.2 & January & 11.3 & 4.09 & 5.01 \\
\hline February & 11.7 & 1.85 & 2.27 & February & 4.80 & .778 & .917 \\
\hline March & 33.2 & 12.9 & 14.2 & March & 9.08 & 1.38 & 1.83 \\
\hline April & 16.9 & 2.53 & 3.17 & April & 9.70 & 1.39 & 1.91 \\
\hline May & 37.7 & 24.4 & 25.9 & May & 6.95 & 1.07 & 1.31 \\
\hline June & 20.5 & 3.53 & 4.35 & June & 20.4 & 9.14 & 11.0 \\
\hline July & 17.7 & 3.17 & 3.74 & July & 35.6 & 13.5 & 15.3 \\
\hline August & 12.2 & 2.11 & 2.47 & August & 8.02 & 1.26 & 1.59 \\
\hline September & 11.2 & 2.10 & 2.46 & September & 4.50 & .763 & .880 \\
\hline \multicolumn{4}{|c|}{ Water year 1995} & \multicolumn{4}{|c|}{ Water year 1996} \\
\hline October & 6.02 & 1.06 & 1.38 & October & 22.0 & 16.6 & 14.7 \\
\hline November & 3.91 & .692 & .876 & November & 13.3 & 5.02 & 5.93 \\
\hline December & 7.52 & 2.47 & 3.19 & December & 14.6 & 11.2 & 11.7 \\
\hline January & 10.9 & 3.17 & 3.89 & January & 16.0 & 5.84 & 6.57 \\
\hline February & 6.05 & .982 & 1.25 & February & 15.1 & 5.16 & 6.01 \\
\hline March & 15.4 & 4.66 & 5.64 & March & 21.3 & 8.74 & 9.80 \\
\hline April & 21.4 & 6.81 & 8.10 & April & 27.8 & 10.3 & 11.6 \\
\hline May & 40.7 & 29.6 & 30.7 & May & 9.62 & 1.37 & 1.67 \\
\hline June & 17.0 & 3.36 & 4.61 & June & 10.4 & 1.46 & 1.87 \\
\hline July & 11.1 & 1.73 & 2.11 & July & 15.2 & 2.51 & 3.13 \\
\hline August & 30.7 & 19.3 & 20.8 & August & 17.4 & 3.51 & 4.38 \\
\hline September & & & & September & 8.34 & 1.36 & 1.71 \\
\hline \multicolumn{4}{|c|}{ Water year 1997} & \multicolumn{4}{|c|}{ Water year 1998} \\
\hline October & 4.90 & 0.790 & 0.925 & October & 13.3 & 5.43 & 6.19 \\
\hline November & 3.76 & .662 & .756 & November & 21.4 & 13.3 & 13.9 \\
\hline December & 8.97 & 2.66 & 3.23 & December & 11.0 & 3.69 & 4.19 \\
\hline January & 10.9 & 3.16 & 3.75 & January & 37.9 & 24.5 & 25.1 \\
\hline February & 13.07 & 3.14 & 3.77 & February & 16.3 & 4.92 & 5.46 \\
\hline March & 14.0 & 4.47 & 5.22 & March & 23.3 & 15.5 & 16.0 \\
\hline April & 10.8 & 2.14 & 2.82 & April & 16.1 & 4.18 & 4.73 \\
\hline May & 27.1 & 16.0 & 17.2 & May & 11.2 & 2.74 & 3.17 \\
\hline June & 49.5 & 26.3 & 27.7 & June & 8.88 & 2.19 & 2.51 \\
\hline July & 85.0 & 58.8 & 59.9 & July & 22.4 & 7.57 & 8.37 \\
\hline August & 21.5 & 4.44 & 5.04 & August & 10.5 & 2.72 & 3.09 \\
\hline September & 8.60 & 1.56 & 1.78 & September & 27.2 & 18.6 & 19.2 \\
\hline
\end{tabular}


Appendix 2. Monthly mean load tables for selected surface-water sites in the J.B. Converse Lake watershed, Mobile County, Alabama, 1990-98-Continued

$[\mathrm{kg} / \mathrm{d}$, kilograms per day]

Crooked Creek near Fairview, 02479980 (site CRO) Total inorganic nitrogen

\begin{tabular}{|c|c|c|c|c|c|c|c|}
\hline Month & $\begin{array}{c}\text { Daily mean } \\
\text { constituent } \\
\text { discharge } \\
\text { (kg/d) }\end{array}$ & $\begin{array}{c}\text { Standard } \\
\text { error } \\
(\mathbf{k g} / \mathrm{d}) \\
\end{array}$ & $\begin{array}{c}\text { Standard } \\
\text { error of } \\
\text { prediction } \\
(\mathrm{kg} / \mathrm{d})\end{array}$ & Month & $\begin{array}{c}\text { Daily mean } \\
\text { constituent } \\
\text { discharge } \\
\text { (kg/d) }\end{array}$ & $\begin{array}{c}\text { Standard } \\
\text { error } \\
(\mathbf{k g} / \mathrm{d})\end{array}$ & $\begin{array}{c}\text { Standard } \\
\text { error of } \\
\text { prediction } \\
(\mathrm{kg} / \mathrm{d})\end{array}$ \\
\hline \multicolumn{4}{|c|}{ Water year 1991} & \multicolumn{4}{|c|}{ Water year 1992} \\
\hline October & 10.9 & 1.97 & 2.20 & October & 10.4 & 1.24 & 1.56 \\
\hline November & 12.3 & 1.95 & 2.28 & November & 13.0 & 1.83 & 2.27 \\
\hline December & 14.9 & 2.45 & 2.89 & December & 11.5 & 1.39 & 1.74 \\
\hline January & 28.1 & 11.6 & 11.9 & January & 17.0 & 3.26 & 3.73 \\
\hline February & 20.3 & 3.46 & 4.06 & February & 19.9 & 4.67 & 5.17 \\
\hline March & 21.0 & 3.85 & 4.41 & March & 15.9 & 1.91 & 2.45 \\
\hline April & 22.5 & 4.14 & 4.75 & April & 11.8 & 1.51 & 1.86 \\
\hline May & 32.5 & 9.89 & 10.4 & May & 11.2 & 1.59 & 1.92 \\
\hline June & 19.1 & 2.99 & 3.40 & June & 12.6 & 1.61 & 2.03 \\
\hline July & 18.9 & 3.10 & 3.60 & July & 10.2 & 1.39 & 1.68 \\
\hline August & 14.0 & 1.99 & 2.36 & August & 9.34 & 1.26 & 1.52 \\
\hline September & 11.8 & 1.50 & 1.85 & September & 9.19 & 1.21 & 1.51 \\
\hline \multicolumn{4}{|c|}{ Water year 1993} & \multicolumn{4}{|c|}{ Water year 1994} \\
\hline October & 8.09 & 1.01 & 1.32 & October & 8.90 & 1.44 & 1.73 \\
\hline November & 13.9 & 2.55 & 2.93 & November & 8.58 & 1.23 & 1.46 \\
\hline December & 13.1 & 2.36 & 2.74 & December & 8.93 & 1.29 & 1.53 \\
\hline January & 13.9 & 2.70 & 3.02 & January & 11.1 & 1.79 & 2.14 \\
\hline February & 13.6 & 1.92 & 2.32 & February & 8.92 & 1.26 & 1.51 \\
\hline March & 18.2 & 3.69 & 4.17 & March & 10.9 & 1.42 & 1.76 \\
\hline April & 14.6 & 1.95 & 2.38 & April & 10.6 & 1.40 & 1.74 \\
\hline May & 16.1 & 3.30 & 3.69 & May & 8.93 & 1.38 & 1.61 \\
\hline June & 13.9 & 2.05 & 2.44 & June & 10.7 & 2.11 & 2.46 \\
\hline July & 12.8 & 1.95 & 2.28 & July & 14.6 & 3.05 & 3.45 \\
\hline August & 10.9 & 1.64 & 1.92 & August & 8.79 & 1.24 & 1.48 \\
\hline September & 10.7 & 1.72 & 1.99 & September & 7.27 & 1.13 & 1.31 \\
\hline \multicolumn{4}{|c|}{ Water year 1995} & \multicolumn{4}{|c|}{ Water year 1996} \\
\hline October & 8.16 & 1.19 & 1.42 & October & 11.9 & 3.01 & 3.31 \\
\hline November & 7.31 & 1.14 & 1.33 & November & 11.2 & 2.13 & 2.45 \\
\hline December & 8.79 & 1.48 & 1.76 & December & 11.5 & 3.07 & 3.30 \\
\hline January & 10.9 & 1.87 & 2.20 & January & 13.7 & 2.74 & 3.10 \\
\hline February & 9.57 & 1.34 & 1.63 & February & 13.7 & 2.34 & 2.74 \\
\hline March & 12.5 & 1.98 & 2.38 & March & 14.8 & 2.76 & 3.17 \\
\hline April & 13.6 & 2.29 & 2.72 & April & 16.8 & 3.04 & 3.50 \\
\hline May & 15.3 & 5.16 & 5.46 & May & 11.1 & 1.46 & 1.77 \\
\hline June & 11.9 & 1.64 & 2.04 & June & 10.7 & 1.42 & 1.74 \\
\hline July & 10.4 & 1.45 & 1.74 & July & 12.1 & 1.66 & 2.02 \\
\hline August & 13.2 & 3.00 & 3.33 & August & 12.7 & 1.95 & 2.31 \\
\hline September & 8.58 & 1.20 & 1.43 & September & 9.96 & 1.39 & 1.68 \\
\hline \multicolumn{4}{|c|}{ Water year 1997} & \multicolumn{4}{|c|}{ Water year 1998} \\
\hline October & 8.54 & 1.19 & 1.42 & October & 12.5 & 2.61 & 2.92 \\
\hline November & 8.14 & 1.20 & 1.41 & November & 15.8 & 5.22 & 5.52 \\
\hline December & 10.9 & 1.88 & 2.20 & December & 13.9 & 2.91 & 3.22 \\
\hline January & 12.6 & 2.20 & 2.55 & January & 25.2 & 10.9 & 11.2 \\
\hline February & 14.2 & 2.37 & 2.80 & February & 18.2 & 4.03 & 4.43 \\
\hline March & 13.4 & 2.42 & 2.81 & March & 19.0 & 5.78 & 6.07 \\
\hline April & 12.0 & 1.87 & 2.23 & April & 16.8 & 3.50 & 3.87 \\
\hline May & 14.2 & 4.17 & 4.49 & May & 13.5 & 2.88 & 3.16 \\
\hline June & 20.3 & 6.36 & 6.75 & June & 11.8 & 2.69 & 2.92 \\
\hline July & 27.4 & 12.1 & 12.3 & July & 16.6 & 4.13 & 4.47 \\
\hline August & 16.2 & 2.93 & 3.30 & August & 12.6 & 2.83 & 3.08 \\
\hline September & & & & September & 17.5 & 6.94 & 7.19 \\
\hline
\end{tabular}


Appendix 2. Monthly mean load tables for selected surface-water sites in the J.B. Converse Lake watershed, Mobile County, Alabama, 1990-98-Continued

[kg/d, kilograms per day]

\section{Crooked Creek near Fairview, 02479980 (site CRO)}

Total phosphorus

\begin{tabular}{|c|c|c|c|c|c|c|c|}
\hline Month & $\begin{array}{c}\text { Daily mean } \\
\text { constituent } \\
\text { discharge } \\
\text { (kg/d) }\end{array}$ & $\begin{array}{c}\text { Standard } \\
\text { error } \\
\text { (kg/d) }\end{array}$ & $\begin{array}{c}\text { Standard } \\
\text { error of } \\
\text { prediction } \\
\text { (kg/d) }\end{array}$ & Month & $\begin{array}{c}\text { Daily mean } \\
\text { constituent } \\
\text { discharge } \\
(\mathbf{k g} / \mathrm{d})\end{array}$ & $\begin{array}{c}\text { Standard } \\
\text { error } \\
(\mathbf{k g} / \mathbf{d})\end{array}$ & $\begin{array}{c}\text { Standard } \\
\text { error of } \\
\text { prediction } \\
(\mathrm{kg} / \mathrm{d})\end{array}$ \\
\hline \multicolumn{4}{|c|}{ Water year 1991} & \multicolumn{4}{|c|}{ Water year 1992} \\
\hline October & 0.323 & 0.078 & 0.092 & October & .407 & .088 & .106 \\
\hline November & .585 & .148 & .212 & November & 1.17 & .410 & .563 \\
\hline December & 1.26 & .426 & .565 & December & .656 & .132 & .167 \\
\hline January & 10.6 & 7.22 & 8.01 & January & 3.20 & 1.52 & 1.94 \\
\hline February & 2.74 & .974 & 1.29 & February & 5.04 & 2.56 & 3.16 \\
\hline March & 3.29 & 1.30 & 1.69 & March & 1.88 & .485 & .717 \\
\hline April & 3.32 & 1.16 & 1.43 & April & .677 & .144 & .177 \\
\hline May & 8.42 & 4.36 & 4.95 & May & .702 & .144 & .236 \\
\hline June & 4.68 & .454 & .558 & June & .915 & .201 & .294 \\
\hline July & 1.84 & .595 & .731 & July & .462 & .101 & .129 \\
\hline August & .769 & .183 & .223 & August & .380 & .081 & .106 \\
\hline September & .544 & .123 & .157 & September & .479 & .110 & .177 \\
\hline \multicolumn{4}{|c|}{ Water year 1993} & \multicolumn{4}{|c|}{ Water year 1994} \\
\hline October & 0.284 & 0.061 & 0.075 & October & .839 & .329 & .534 \\
\hline November & 1.81 & .710 & .880 & November & .471 & .093 & .123 \\
\hline December & 2.27 & 1.13 & 1.56 & December & .569 & .110 & .146 \\
\hline January & 6.40 & 4.95 & 6.45 & January & 1.76 & .710 & 1.10 \\
\hline February & 1.41 & .275 & .377 & February & .553 & .111 & .141 \\
\hline March & 4.37 & 1.83 & 2.28 & March & 1.07 & .119 & .317 \\
\hline April & 1.58 & .304 & .418 & April & .934 & .169 & .273 \\
\hline May & 5.75 & 3.66 & 4.90 & May & .511 & .109 & .143 \\
\hline June & 1.34 & .296 & .400 & June & 1.74 & .779 & 1.22 \\
\hline July & 1.06 & .229 & .299 & July & 2.77 & 1.22 & 1.54 \\
\hline August & .707 & .143 & .186 & August & .478 & .094 & .134 \\
\hline September & .738 & .159 & .208 & September & .275 & .062 & .074 \\
\hline \multicolumn{4}{|c|}{ Water year 1995} & \multicolumn{4}{|c|}{ Water year 1996} \\
\hline October & 0.481 & 0.102 & 0.157 & October & 2.72 & 1.65 & 2.06 \\
\hline November & .388 & .080 & .127 & November & 1.73 & .797 & 1.08 \\
\hline December & 1.01 & .385 & .615 & December & 11.0 & 10.5 & 12.7 \\
\hline January & 1.72 & .620 & .877 & January & 2.83 & 1.23 & 1.54 \\
\hline February & .801 & .155 & .230 & February & 2.77 & 1.13 & 1.56 \\
\hline March & 2.30 & .811 & 1.20 & March & 3.63 & 1.56 & 2.12 \\
\hline April & 2.68 & .964 & 1.37 & April & 4.11 & 1.71 & 2.31 \\
\hline May & 14.2 & 11.6 & 14.1 & May & .869 & .187 & .231 \\
\hline June & 1.40 & .378 & .606 & June & .814 & .174 & .232 \\
\hline July & .739 & .149 & .198 & July & 1.16 & .288 & .370 \\
\hline August & 3.55 & 2.22 & 2.91 & August & 1.39 & .423 & .548 \\
\hline September & .454 & .096 & .121 & September & .693 & .172 & .228 \\
\hline \multicolumn{4}{|c|}{ Water year 1997} & \multicolumn{4}{|c|}{ Water year 1998} \\
\hline October & 0.444 & 0.108 & 0.127 & October & 1.77 & .870 & 1.14 \\
\hline November & .414 & .105 & .123 & November & 4.39 & 2.80 & 3.25 \\
\hline December & 1.43 & .559 & .751 & December & 2.05 & .888 & 1.13 \\
\hline January & 2.01 & .787 & 1.02 & January & 13.1 & 9.19 & 10.2 \\
\hline February & 2.31 & .772 & .989 & February & 3.25 & 1.24 & 1.47 \\
\hline March & 2.37 & .875 & 1.18 & March & 9.51 & 6.64 & 8.13 \\
\hline April & 1.41 & .381 & .568 & April & 2.35 & .733 & .909 \\
\hline May & 3.93 & 2.07 & 2.69 & May & 1.26 & .346 & .454 \\
\hline June & 5.80 & 3.00 & 3.47 & June & .838 & .226 & .302 \\
\hline July & 14.2 & 10.1 & 11.1 & July & 2.23 & .884 & 1.07 \\
\hline August & 1.86 & .586 & .672 & August & .948 & .292 & .369 \\
\hline September & .758 & .201 & .233 & September & 20.6 & 22.0 & 24.8 \\
\hline
\end{tabular}


Appendix 2. Monthly mean load tables for selected surface-water sites in the J.B. Converse Lake watershed, Mobile County, Alabama, 1990-98-Continued

[kg/d, kilograms per day]

Hamilton Creek at Snow Road near Semmes, 02480002 (site HAM)

Total nitrogen

\begin{tabular}{|c|c|c|c|c|c|c|c|}
\hline Month & $\begin{array}{c}\text { Daily mean } \\
\text { constituent } \\
\text { discharge } \\
(\mathbf{k g} / \mathrm{d})\end{array}$ & $\begin{array}{c}\text { Standard } \\
\text { error } \\
(\mathrm{kg} / \mathrm{d})\end{array}$ & $\begin{array}{c}\text { Standard } \\
\text { error of } \\
\text { prediction } \\
(\mathbf{k g} / \mathrm{d})\end{array}$ & Month & $\begin{array}{c}\text { Daily mean } \\
\text { constituent } \\
\text { discharge } \\
(\mathrm{kg} / \mathrm{d})\end{array}$ & $\begin{array}{c}\text { Standard } \\
\text { error } \\
(\mathbf{k g} / \mathrm{d})\end{array}$ & $\begin{array}{c}\text { Standard } \\
\text { error of } \\
\text { prediction } \\
(\mathrm{kg} / \mathrm{d})\end{array}$ \\
\hline \multicolumn{4}{|c|}{ Water year 1991} & \multicolumn{4}{|c|}{ Water year 1992} \\
\hline October & 31.5 & 2.01 & 2.12 & October & 33.3 & 1.33 & 1.52 \\
\hline November & 31.0 & 1.91 & 2.04 & November & 36.4 & 1.44 & 1.69 \\
\hline December & 35.8 & 1.83 & 2.02 & December & 36.5 & 1.66 & 1.85 \\
\hline January & 81.5 & 6.57 & 7.13 & January & 51.9 & 2.79 & 3.07 \\
\hline February & 45.5 & 2.20 & 2.48 & February & 58.3 & 2.92 & 3.37 \\
\hline March & 46.6 & 2.09 & 2.37 & March & 42.5 & 1.70 & 1.97 \\
\hline April & 53.4 & 2.33 & 2.72 & April & 34.5 & 1.17 & 1.40 \\
\hline May & 74.6 & 5.53 & 6.02 & May & 32.5 & 1.30 & 1.49 \\
\hline June & 44.3 & 1.85 & 2.11 & June & 40.8 & 1.50 & 1.78 \\
\hline July & 46.2 & 1.99 & 2.26 & July & 35.4 & 1.35 & 1.56 \\
\hline August & 41.1 & 1.70 & 1.92 & August & 31.4 & 1.41 & 1.58 \\
\hline September & 39.2 & 1.59 & 1.81 & September & 32.2 & 1.41 & 1.61 \\
\hline \multicolumn{4}{|c|}{ Water year 1993} & \multicolumn{4}{|c|}{ Water year 1994} \\
\hline October & 27.7 & 1.46 & 1.58 & October & 31.0 & 1.64 & $\cdot 1.82$ \\
\hline November & 41.8 & 2.18 & 2.44 & November & 32.8 & 1.82 & 1.96 \\
\hline December & 39.3 & 1.99 & 2.25 & December & 31.2 & 1.74 & 1.87 \\
\hline January & 65.0 & 11.5 & 12.0 & January & 34.1 & 1.92 & 2.08 \\
\hline February & 39.5 & 2.10 & 2.30 & February & 27.8 & 1.52 & 1.65 \\
\hline March & 58.5 & 4.09 & 4.53 & March & 36.3 & 1.84 & 2.02 \\
\hline April & 42.7 & 1.94 & 2.18 & April & 35.0 & 1.57 & 1.77 \\
\hline May & 47.6 & 2.47 & 2.80 & May & 28.7 & 1.47 & 1.60 \\
\hline June & 36.3 & 1.48 & 1.70 & June & 48.3 & 4.59 & 4.93 \\
\hline July & 38.6 & 1.77 & 1.97 & July & 38.6 & 1.96 & 2.16 \\
\hline August & 33.0 & 1.51 & 1.67 & August & 28.7 & 1.52 & 1.65 \\
\hline September & 31.0 & 1.49 & 1.65 & September & 26.8 & 1.57 & 1.68 \\
\hline \multicolumn{4}{|c|}{ Water year 1995} & \multicolumn{4}{|c|}{ Water year 1996} \\
\hline October & 30.5 & 1.67 & 1.83 & October & 48.5 & 4.75 & 5.10 \\
\hline November & 29.5 & 1.72 & 1.89 & November & 39.1 & 2.38 & 2.58 \\
\hline December & 31.5 & 1.83 & 1.98 & December & 82.3 & 27.5 & 28.1 \\
\hline January & 37.9 & 2.31 & 2.51 & January & 40.5 & 2.52 & 2.72 \\
\hline February & 30.6 & 1.68 & 1.83 & February & 42.9 & 2.65 & 2.98 \\
\hline March & 39.4 & 2.14 & 2.35 & March & 47.5 & 3.40 & 3.74 \\
\hline April & 48.1 & 3.00 & 3.31 & April & 57.9 & 4.34 & 4.70 \\
\hline May & 82.2 & 20.6 & 21.0 & May & 32.3 & 1.37 & 1.55 \\
\hline June & 36.6 & 1.67 & 1.89 & June & 38.9 & 1.82 & 2.08 \\
\hline July & 35.1 & 1.59 & 1.77 & July & 35.6 & 1.53 & 1.73 \\
\hline August & 43.4 & 3.07 & 3.37 & August & 39.0 & 1.81 & 2.02 \\
\hline September & 25.1 & 1.60 & 1.70 & September & 32.1 & 1.49 & 1.65 \\
\hline \multicolumn{4}{|c|}{ Water year 1997} & \multicolumn{4}{|c|}{ Water year 1998} \\
\hline October & 28.8 & 1.48 & 1.61 & October & 38.4 & 2.23 & 2.45 \\
\hline November & 27.8 & 1.57 & 1.69 & November & 52.9 & 3.83 & 4.14 \\
\hline December & 33.2 & 1.89 & 2.07 & December & 41.0 & 2.88 & 3.02 \\
\hline January & 31.0 & 1.84 & 1.97 & January & 92.4 & 20.0 & 20.4 \\
\hline February & 34.6 & 1.97 & 2.15 & February & 40.6 & 2.91 & 3.08 \\
\hline March & 34.8 & 1.98 & 2.18 & March & 74.8 & 18.8 & 19.2 \\
\hline April & 31.5 & 1.79 & 1.95 & April & 36.5 & 2.66 & 2.80 \\
\hline May & 41.7 & 3.00 & 3.24 & May & 33.3 & 2.53 & 2.63 \\
\hline June & 52.7 & 3.86 & 4.17 & June & 28.9 & 2.59 & 2.68 \\
\hline July & 94.0 & 19.2 & 19.7 & July & 35.9 & 2.76 & 2.88 \\
\hline August & 37.1 & 1.87 & 2.04 & August & 28.3 & 2.52 & 2.60 \\
\hline September & 35.1 & 1.88 & 2.03 & September & 165 & 99.8 & 100 \\
\hline
\end{tabular}


Appendix 2. Monthly mean load tables for selected surface-water sites in the J.B. Converse Lake watershed, Mobile County, Alabama, 1990-98-Continued

$[\mathrm{kg} / \mathrm{d}$, kilograms per day]

Hamilton Creek at Snow Road near Semmes, 02480002 (site HAM)

Total Kjeldahl nitrogen

\begin{tabular}{|c|c|c|c|c|c|c|c|}
\hline Month & $\begin{array}{c}\text { Daily mean } \\
\text { constituent } \\
\text { discharge } \\
(\mathrm{kg} / \mathrm{d})\end{array}$ & $\begin{array}{c}\text { Standard } \\
\text { error } \\
(\mathbf{k g} / \mathrm{d})\end{array}$ & $\begin{array}{c}\text { Standard } \\
\text { error of } \\
\text { prediction } \\
(\mathbf{k g} / \mathrm{d})\end{array}$ & Month & $\begin{array}{l}\text { Daily mean } \\
\text { constituent } \\
\text { discharge } \\
\text { (kg/d) }\end{array}$ & $\begin{array}{l}\text { Standard } \\
\text { error } \\
(\mathbf{k g} / \mathrm{d})\end{array}$ & $\begin{array}{c}\text { Standard } \\
\text { error of } \\
\text { prediction } \\
(\mathrm{kg} / \mathrm{d})\end{array}$ \\
\hline \multicolumn{4}{|c|}{ Water year 1991} & \multicolumn{4}{|c|}{ Water year 1992} \\
\hline October & 8.44 & 1.17 & 1.29 & October & 9.51 & .940 & 1.12 \\
\hline November & 7.83 & .994 & 1.19 & November & 11.8 & 1.25 & 1.72 \\
\hline December & 11.1 & 1.28 & 1.74 & December & 10.3 & 1.07 & 1.29 \\
\hline January & 53.9 & 18.4 & 19.8 & 'January & 22.6 & 3.05 & 3.75 \\
\hline February & 18.0 & 2.11 & 2.80 & February & 30.2 & 5.49 & 6.66 \\
\hline March & 20.1 & 2.38 & 2.98 & March & 16.2 & 1.63 & 2.14 \\
\hline April & 30.6 & 4.53 & 5.61 & April & 10.9 & .998 & 1.23 \\
\hline May & 58.3 & 17.2 & 18.9 & May & 10.7 & 1.05 & 1.33 \\
\hline June & 22.4 & 2.67 & 3.15 & June & 18.7 & 2.02 & 2.53 \\
\hline July & 24.9 & 3.14 & 3.73 & July & 13.5 & 1.33 & 1.63 \\
\hline August & 17.8 & 2.03 & 2.34 & August & 10.1 & 1.03 & 1.27 \\
\hline September & 15.1 & 1.68 & 1.97 & September & 10.5 & 1.13 & 1.50 \\
\hline \multicolumn{4}{|c|}{ Water year 1993} & \multicolumn{4}{|c|}{ Water year 1994} \\
\hline October & 6.08 & 0.753 & 0.849 & October & 9.07 & 1.25 & 1.70 \\
\hline November & 16.4 & 2.49 & 3.09 & November & 8.35 & 1.06 & 1.20 \\
\hline December & 13.7 & 1.99 & 2.68 & December & 7.01 & .870 & .992 \\
\hline January & 28.5 & 19.3 & 20.3 & January & 9.23 & 1.18 & 1.49 \\
\hline February & 12.5 & 1.45 & 1.76 & February & 5.47 & .720 & .810 \\
\hline March & 32.8 & 9.94 & 11.1 & March & 11.1 & 1.30 & 1.59 \\
\hline April & 17.6 & 2.05 & 2.53 & April & 11.3 & 1.24 & 1.50 \\
\hline May & 26.3 & 5.08 & 6.14 & May & 7.77 & .945 & 1.10 \\
\hline June & 14.1 & 1.50 & 1.81 & June & 30.7 & 11.4 & 12.6 \\
\hline July & 16.2 & 1.94 & 2.25 & July & 17.1 & 2.37 & 2.82 \\
\hline August & 11.0 & 1.22 & 1.44 & August & 7.75 & .961 & 1.08 \\
\hline September & 6.80 & 1.01 & 1.18 & September & 6.09 & .836 & .926 \\
\hline \multicolumn{4}{|c|}{ Water year 1995} & \multicolumn{4}{|c|}{ Water year 1996} \\
\hline October & 8.65 & 1.20 & 1.58 & October & 26.0 & 10.4 & 11.4 \\
\hline November & 7.50 & 1.12 & 1.54 & November & 13.1 & 2.04 & 2.45 \\
\hline December & 8.04 & 1.13 & 1.47 & December & 23.8 & 19.9 & 20.4 \\
\hline January & 12.1 & 1.89 & 2.34 & January & 12.9 & 1.97 & 2.40 \\
\hline February & 6.83 & .837 & .963 & February & 15.5 & 3.62 & 4.38 \\
\hline March & 13.9 & 1.91 & 2.33 & March & 21.2 & 6.32 & 7.14 \\
\hline April & 24.3 & 5.34 & 6.16 & April & 31.6 & 9.13 & 10.0 \\
\hline May & 47.1 & 36.8 & 37.7 & May & 9.69 & 1.03 & 1.21 \\
\hline June & 14.5 & 1.76 & 2.21 & June & 16.9 & 2.38 & 2.99 \\
\hline July & 12.7 & 1.41 & 1.65 & July & 13.2 & 1.47 & 1.78 \\
\hline August & 23.0 & 6.35 & 7.39 & August & 15.5 & 1.93 & 2.27 \\
\hline September & 5.23 & .760 & .838 & September & 9.17 & 1.07 & 1.24 \\
\hline \multicolumn{4}{|c|}{ Water year 1997} & \multicolumn{4}{|c|}{ Water year 1998} \\
\hline October & 6.51 & 0.819 & 0.922 & October & 13.1 & 2.28 & 2.79 \\
\hline November & 5.51 & .747 & .831 & November & 22.0 & 5.57 & 6.20 \\
\hline December & 8.75 & 1.25 & 1.58 & December & 11.6 & 1.98 & 2.15 \\
\hline January & 6.88 & .935 & 1.07 & January & 34.9 & 18.3 & 18.8 \\
\hline February & 9.32 & 1.25 & 1.51 & February & 12.0 & 2.09 & 2.31 \\
\hline March & 10.9 & 1.74 & 2.18 & March & 24.9 & 16.1 & 16.6 \\
\hline April & 9.40 & 1.27 & 1.58 & April & 11.6 & 2.07 & 2.29 \\
\hline May & 20.4 & 4.84 & 5.54 & May & 10.0 & 1.83 & 1.95 \\
\hline June & 29.7 & 7.64 & 8.47 & June & 8.75 & 1.70 & 1.91 \\
\hline July & 55.9 & 29.8 & 30.6 & July & 12.9 & 2.39 & 2.58 \\
\hline August & 13.2 & 1.75 & 1.97 & August & 7.75 & 1.52 & 1.63 \\
\hline September & 10.8 & 1.51 & 1.68 & September & 38.6 & 30.7 & 31.3 \\
\hline
\end{tabular}


Appendix 2. Monthly mean load tables for selected surface-water sites in the J.B. Converse Lake watershed, Mobile County, Alabama, 1990-98-Continued

$[\mathrm{kg} / \mathrm{d}$, kilograms per day]

\section{Hamilton Creek at Snow Road near Semmes, 02480002 (site HAM) \\ Total inorganic nitrogen}

\begin{tabular}{|c|c|c|c|c|c|c|c|}
\hline Month & $\begin{array}{c}\text { Daily mean } \\
\text { constituent } \\
\text { discharge } \\
(\mathrm{kg} / \mathrm{d})\end{array}$ & $\begin{array}{l}\text { Standard } \\
\text { error } \\
(\mathbf{k g} / \mathbf{d})\end{array}$ & $\begin{array}{l}\text { Standard } \\
\text { error of } \\
\text { prediction } \\
(\mathrm{kg} / \mathrm{d}\}\end{array}$ & Month & $\begin{array}{l}\text { Daily mean } \\
\text { constituent } \\
\text { discharge } \\
(\mathrm{kg} / \mathrm{d})\end{array}$ & $\begin{array}{c}\text { Standard } \\
\text { error } \\
(\mathbf{k g} / \mathbf{d})\end{array}$ & $\begin{array}{c}\text { Standard } \\
\text { error of } \\
\text { prediction } \\
\text { (kg/d) }\end{array}$ \\
\hline \multicolumn{4}{|c|}{ Water year 1991} & \multicolumn{4}{|c|}{ Water year 1992} \\
\hline October & 19.6 & 0.734 & 0.815 & October & 20.8 & .544 & .660 \\
\hline November & 20.0 & .744 & .830 & November & 21.9 & .549 & .682 \\
\hline December & 22.4 & .737 & .843 & December & 24.5 & .659 & .793 \\
\hline January & 27.8 & .899 & 1.03 & January & 28.0 & .843 & .983 \\
\hline February & 27.2 & .854 & .998 & February & 27.7 & .781 & .937 \\
\hline March & 26.3 & .792 & .924 & March & 25.6 & .645 & .794 \\
\hline April & 25.3 & .766 & .896 & April & 22.2 & .563 & .694 \\
\hline May & 25.6 & .873 & .988 & May & 19.4 & .572 & .672 \\
\hline June & 22.7 & .690 & .806 & June & 21.5 & .579 & .701 \\
\hline July & 22.4 & .697 & .806 & July & 19.7 & .523 & .632 \\
\hline August & 22.0 & .675 & .782 & August & 17.8 & .501 & .596 \\
\hline September & 22.0 & .650 & .765 & September & 18.1 & .501 & .604 \\
\hline \multicolumn{4}{|c|}{ Water year 1993} & \multicolumn{4}{|c|}{ Water year 1994} \\
\hline October & 17.7 & 0.547 & 0.633 & October & 18.3 & .580 & .670 \\
\hline November & 22.7 & .655 & .779 & November & 22.2 & .698 & .808 \\
\hline December & 23.4 & .637 & .765 & December & 22.4 & .676 & .787 \\
\hline January & 24.3 & .655 & .790 & January & 23.3 & .689 & .809 \\
\hline February & 25.9 & .732 & .883 & February & 20.9 & .684 & .790 \\
\hline March & 25.5 & .731 & .864 & March & 24.0 & .683 & .809 \\
\hline April & 24.5 & .690 & .824 & April & 22.5 & .639 & .761 \\
\hline May & 22.6 & .656 & .772 & May & 18.4 & .640 & .722 \\
\hline June & 20.6 & .585 & .697 & June & 18.8 & .661 & .748 \\
\hline July & 20.9 & .641 & .744 & July & 20.0 & .635 & .732 \\
\hline August & 19.1 & .559 & .656 & August & 17.6 & .565 & .648 \\
\hline September & 18.8 & .557 & .656 & September & 17.2 & .587 & .665 \\
\hline \multicolumn{4}{|c|}{ Water year 1995} & \multicolumn{4}{|c|}{ Water year 1996} \\
\hline October & 19.0 & 0.609 & 0.700 & October & 20.1 & .652 & .747 \\
\hline November & 19.2 & .651 & .741 & November & 24.1 & .803 & .917 \\
\hline December & 21.6 & .682 & .786 & December & 23.3 & .718 & .835 \\
\hline January & 23.9 & .739 & .858 & January & 26.4 & .827 & .954 \\
\hline February & 23.3 & .695 & .824 & February & 25.8 & .755 & .896 \\
\hline March & 24.2 & .712 & .837 & March & 24.6 & .716 & .843 \\
\hline April & 23.1 & .723 & .839 & April & 25.3 & .789 & .916 \\
\hline May & 20.7 & .686 & .783 & May & 21.9 & .606 & .723 \\
\hline June & 21.0 & .617 & .727 & June & 21.5 & .616 & .732 \\
\hline July & 20.9 & .623 & .728 & July & 21.1 & .597 & .709 \\
\hline August & 19.7 & .623 & .719 & August & 22.3 & .683 & .793 \\
\hline September & 16.7 & .612 & .684 & September & 21.4 & .622 & .735 \\
\hline \multicolumn{4}{|c|}{ Water year 1997} & \multicolumn{4}{|c|}{ Water year 1998} \\
\hline October & 21.1 & 0.629 & 0.735 & October & 24.2 & .850 & .956 \\
\hline November & 21.8 & .681 & .789 & November & 26.4 & .993 & 1.10 \\
\hline December & 23.8 & .737 & .854 & December & 29.3 & 1.17 & 1.28 \\
\hline January & 24.7 & .771 & .892 & January & 28.7 & 1.20 & 1.31 \\
\hline February & 25.3 & .780 & .918 & February & 29.0 & 1.16 & 1.28 \\
\hline March & 23.5 & .786 & .895 & March & 27.3 & 1.13 & 1.23 \\
\hline April & 21.7 & .787 & .884 & April & 25.7 & 1.10 & 1.20 \\
\hline May & 20.6 & .818 & .900 & May & 24.0 & 1.06 & 1.15 \\
\hline June & 23.1 & .788 & .895 & June & 19.9 & 1.04 & 1.10 \\
\hline July & 23.9 & .967 & 1.06 & July & 22.8 & 1.04 & 1.12 \\
\hline August & 23.2 & .765 & .872 & August & 20.0 & 1.01 & 1.07 \\
\hline September & 23.6 & .809 & .917 & September & 19.3 & 1.08 & 1.14 \\
\hline
\end{tabular}


Appendix 2. Monthly mean load tables for selected surface-water sites in the J.B. Converse Lake watershed, Mobile County, Alabama, 1990-98-Continued

$[\mathrm{kg} / \mathrm{d}$, kilograms per day]

Hamilton Creek at Snow Road near Semmes, 02480002 (site HAM)

Total phosphorus

\begin{tabular}{|c|c|c|c|c|c|c|c|}
\hline Month & $\begin{array}{c}\text { Daily mean } \\
\text { constituent } \\
\text { discharge } \\
(\mathrm{kg} / \mathrm{d}) \\
\end{array}$ & $\begin{array}{c}\text { Standard } \\
\text { error } \\
(\mathbf{k g} / \mathrm{d})\end{array}$ & $\begin{array}{c}\text { Standard } \\
\text { error of } \\
\text { prediction } \\
(\mathbf{k g} / \mathrm{d}) \\
\end{array}$ & Month & $\begin{array}{c}\text { Daily mean } \\
\text { constituent } \\
\text { discharge } \\
\text { (kg/d) } \\
\end{array}$ & $\begin{array}{c}\text { Standard } \\
\text { error } \\
(\mathbf{k g} / \mathrm{d})\end{array}$ & $\begin{array}{c}\text { Standard } \\
\text { error of } \\
\text { prediction } \\
(\mathrm{kg} / \mathrm{d}) \\
\end{array}$ \\
\hline \multicolumn{4}{|c|}{ Water year 1991} & \multicolumn{4}{|c|}{ Water year 1992} \\
\hline October & 0.637 & 0.176 & 0.206 & October & .744 & .184 & .221 \\
\hline November & .595 & .154 & .207 & November & .972 & .242 & .364 \\
\hline December & .902 & .232 & .352 & December & .823 & .184 & .237 \\
\hline January & 5.766 & 3.41 & 4.08 & January & 2.04 & .618 & .822 \\
\hline February & 1.56 & .418 & .611 & February & 2.97 & 1.18 & 1.59 \\
\hline March & 1.78 & .485 & .647 & March & 1.45 & .334 & .478 \\
\hline April & 2.91 & 1.05 & 1.36 & April & .931 & .204 & .258 \\
\hline May & 6.56 & 3.66 & 4.59 & May & .941 & .210 & .283 \\
\hline June & 1.99 & .551 & .677 & June & 1.72 & .426 & .567 \\
\hline July & 2.23 & .663 & .821 & July & 1.18 & .271 & .347 \\
\hline August & 1.51 & .386 & .464 & August & .853 & .196 & .258 \\
\hline September & 1.25 & .313 & .384 & September & .899 & .209 & .311 \\
\hline \multicolumn{4}{|c|}{ Water year 1993} & \multicolumn{4}{|c|}{ Water year 1994} \\
\hline October & 0.479 & 0.123 & 0.147 & October & .821 & .200 & .363 \\
\hline November & 1.49 & .446 & .642 & November & .713 & .160 & .205 \\
\hline December & 1.25 & .368 & .598 & December & .596 & .136 & .172 \\
\hline January & 5.19 & 4.14 & 5.66 & January & .846 & .186 & .301 \\
\hline February & 1.12 & .231 & .333 & February & .470 & .117 & .142 \\
\hline March & 3.83 & 1.92 & 2.61 & March & 1.06 & .221 & .325 \\
\hline April & 1.68 & .390 & .551 & April & 1.09 & .224 & .314 \\
\hline May & 2.79 & 1.04 & 1.49 & May & .732 & .158 & .210 \\
\hline June & 1.31 & .281 & .376 & June & 3.98 & 2.23 & 3.10 \\
\hline July & 1.53 & .342 & .444 & July & 1.75 & .447 & .612 \\
\hline August & .984 & .212 & .276 & August & .710 & .161 & .200 \\
\hline September & .763 & .170 & .218 & September & .540 & .134 & .161 \\
\hline \multicolumn{4}{|c|}{ Water year 1995} & \multicolumn{4}{|c|}{ Water year 1996} \\
\hline October & 0.821 & 0.199 & 0.345 & October & 3.43 & 2.08 & 2.73 \\
\hline November & .716 & .184 & .348 & November & 1.37 & .416 & .575 \\
\hline December & .765 & .190 & .319 & December & 8.92 & 8.77 & 11.1 \\
\hline January & 1.24 & .359 & .537 & January & 1.40 & .435 & .604 \\
\hline February & .638 & .152 & .191 & February & 1.89 & .778 & 1.19 \\
\hline March & 1.47 & .389 & .551 & March & 2.87 & 1.40 & 1.97 \\
\hline April & 2.89 & 1.16 & 1.54 & April & 4.20 & 2.11 & 2.66 \\
\hline May & 11.1 & 9.47 & 11.5 & May & 1.05 & .252 & .307 \\
\hline June & 1.56 & .377 & .549 & June & 2.02 & .623 & .866 \\
\hline July & 1.31 & .290 & .371 & July & 1.50 & .378 & .483 \\
\hline August & 2.86 & 1.35 & 1.95 & August & 1.75 & .483 & .606 \\
\hline September & .490 & .130 & .155 & September & .970 & .252 & .305 \\
\hline \multicolumn{4}{|c|}{ Water year 1997} & \multicolumn{4}{|c|}{ Water year 1998} \\
\hline October & 0.661 & 0.184 & 0.215 & October & 1.63 & .627 & .858 \\
\hline November & .550 & .163 & .188 & November & 3.00 & 1.52 & 1.85 \\
\hline December & .967 & .306 & .431 & December & 1.38 & .472 & .539 \\
\hline January & .734 & .214 & .260 & January & 8.67 & 7.02 & 8.46 \\
\hline February & 1.06 & .316 & .410 & February & 1.51 & .526 & .624 \\
\hline March & 1.34 & .450 & .644 & March & 7.95 & 6.80 & 8.58 \\
\hline April & 1.14 & .330 & .453 & April & 1.54 & .504 & .612 \\
\hline May & 2.84 & 1.28 & 1.65 & May & 1.32 & .403 & .463 \\
\hline June & 4.28 & 2.06 & 2.58 & June & 1.18 & .371 & .493 \\
\hline July & 13.0 & 10.3 & 12.2 & July & 1.75 & .568 & .664 \\
\hline August & 1.59 & .458 & .537 & August & 1.00 & .314 & .374 \\
\hline September & 1.26 & .370 & .430 & September & 33.3 & 39.4 & 44.2 \\
\hline
\end{tabular}




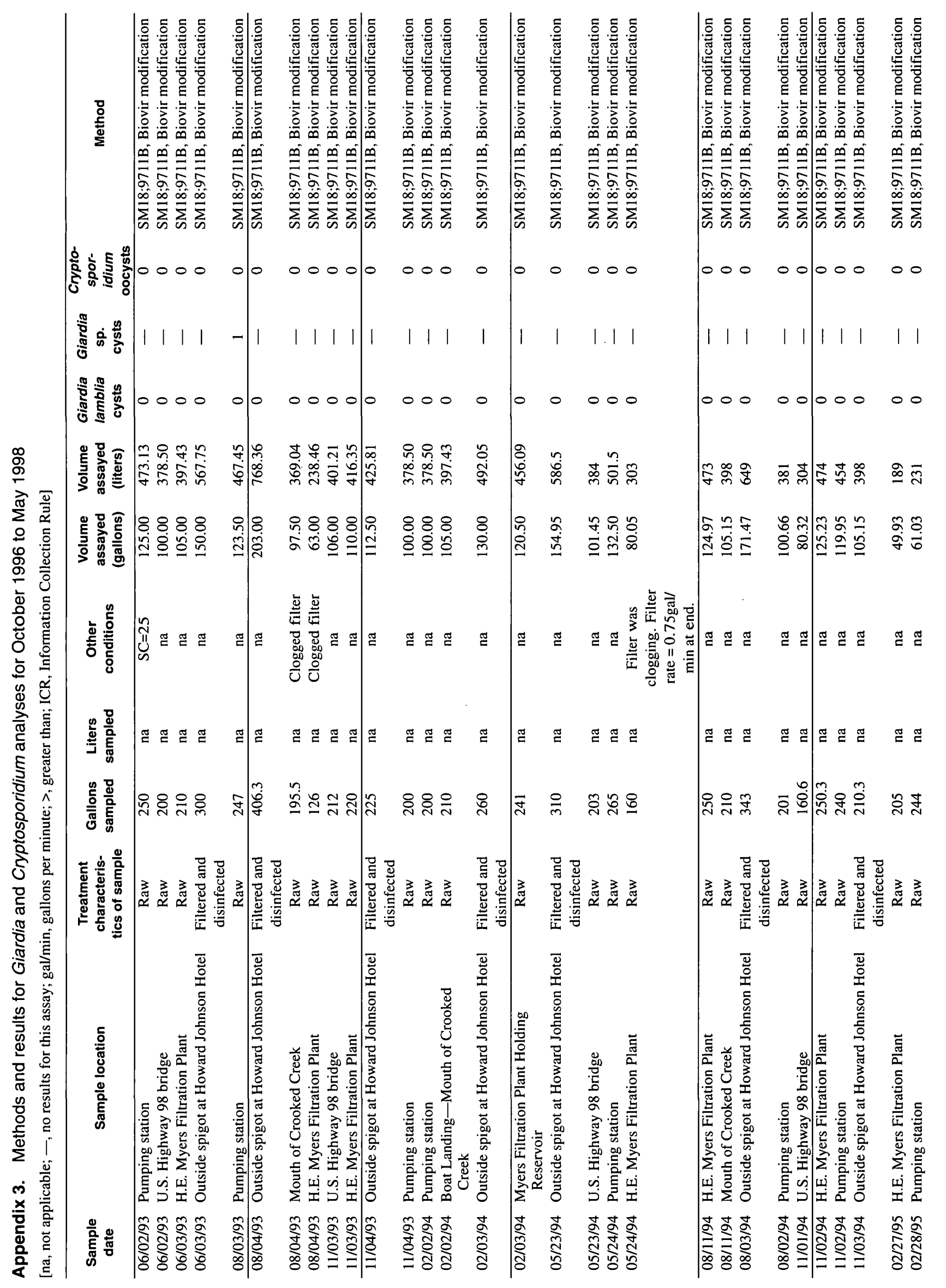




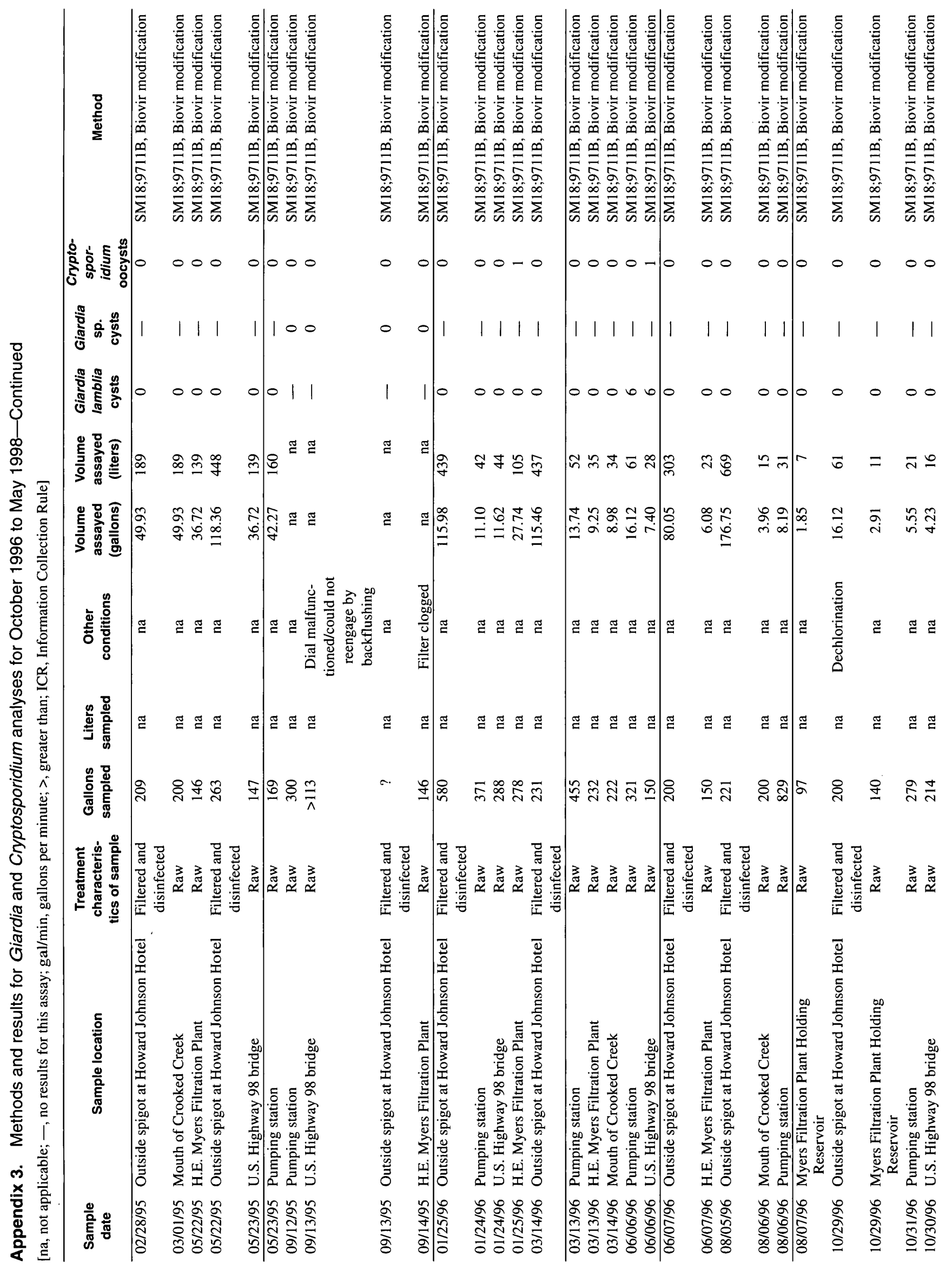




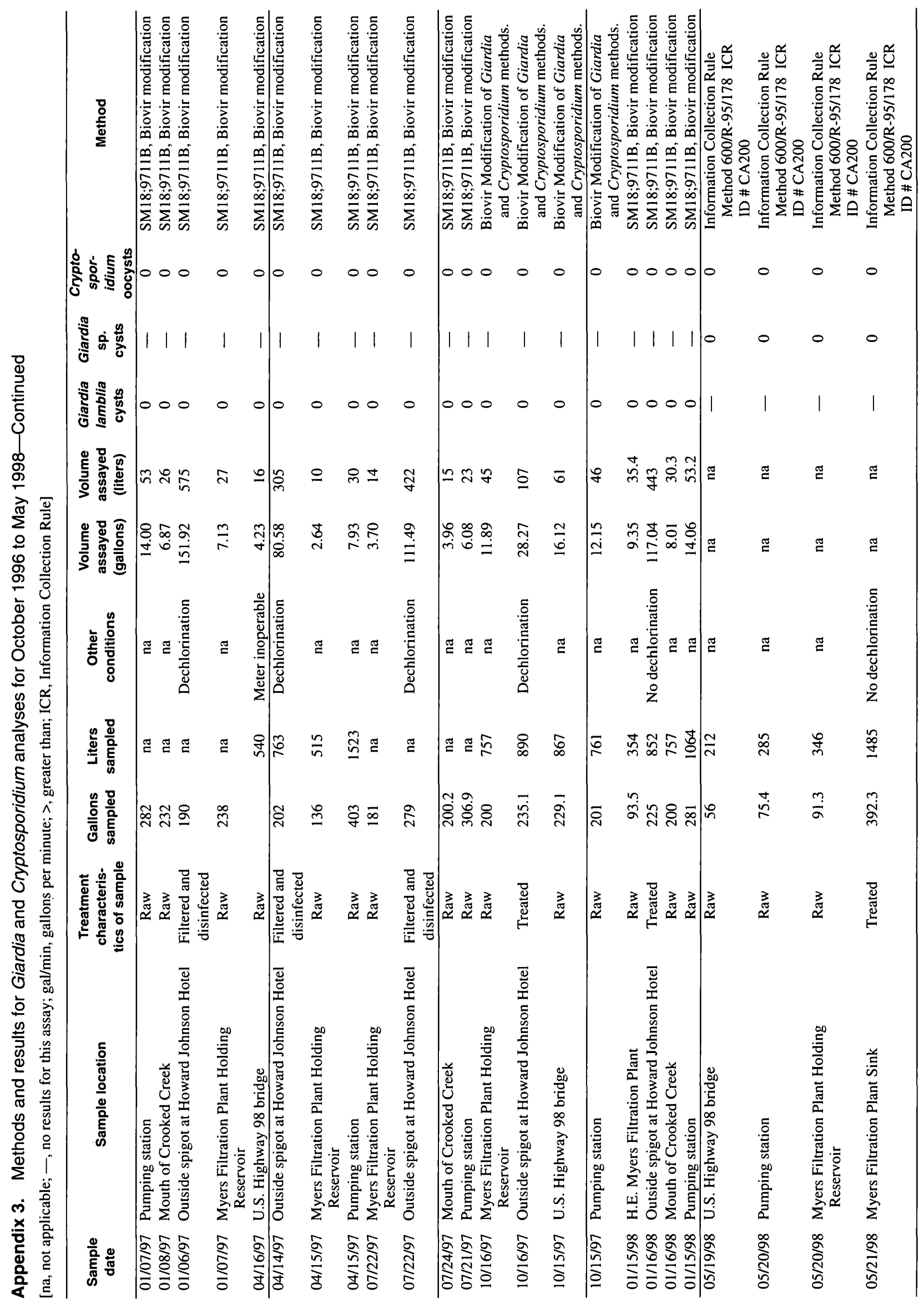

